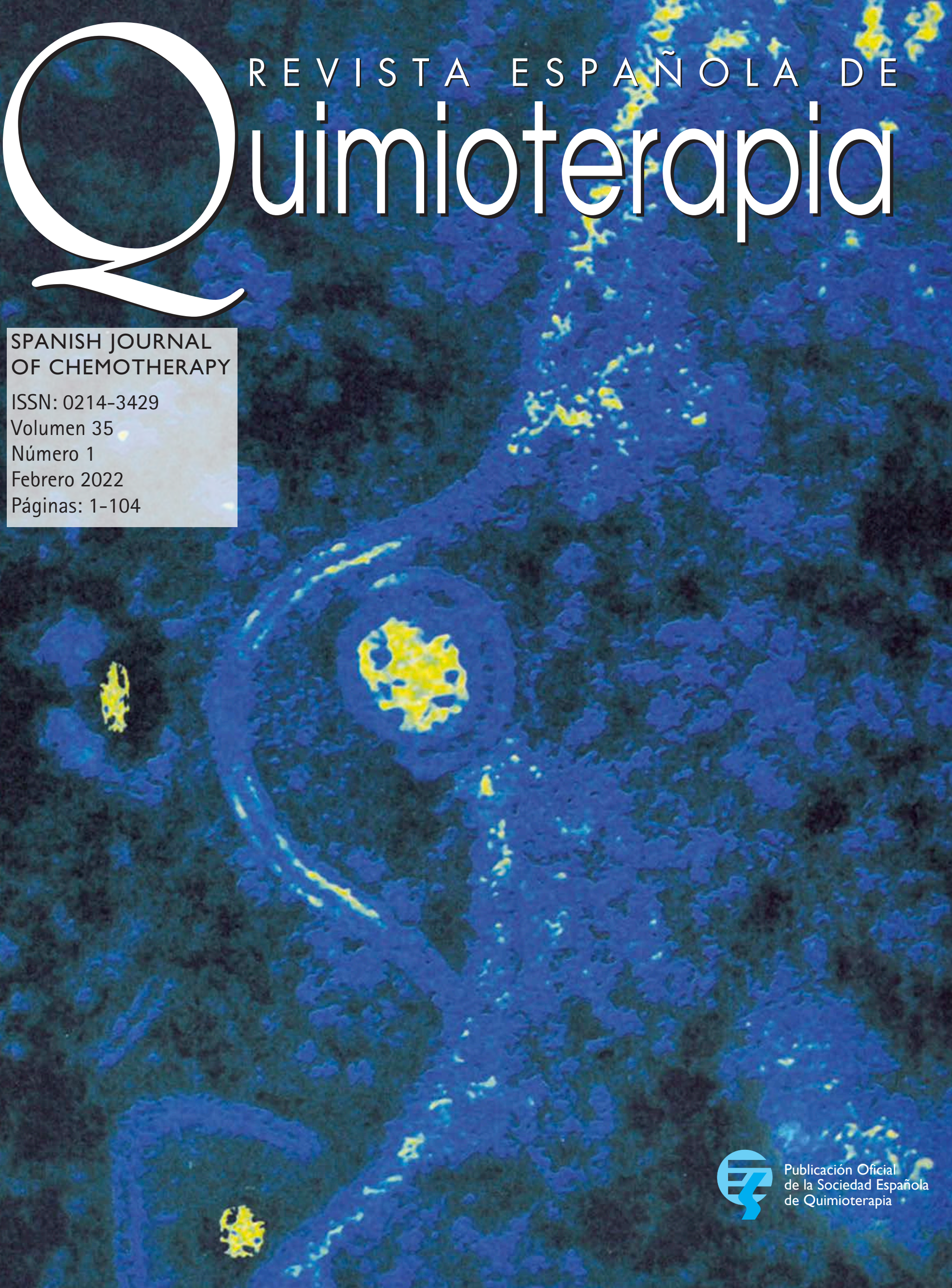




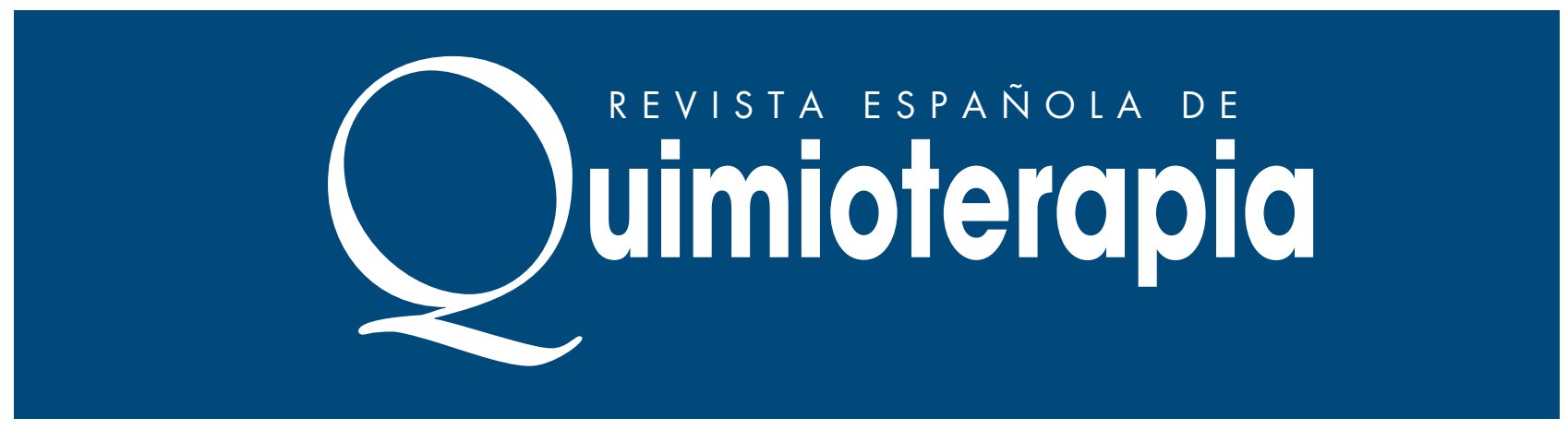

Revista Española de Quimioterapia tiene un carácter multidisciplinar y está dirigida a todos aquellos profesionales involucrados en la epidemiología, diagnóstico, clínica y tratamiento de las enfermedades infecciosas

Fundada en 1988 por la Sociedad Española de Quimioterapia

Indexada en

Science Citation Index Expanded (SCI),

Index Medicus (MEDLINE), Excerpta Medica/EMBASE, Índice Médico Español (IME), Índice Bibliográfico en Ciencias de la Salud (IBECS)

\section{Secretaría técnica}

Dpto. de Microbiología

Facultad de Medicina

Avda. Complutense, s/n

28040 Madrid

revista@seq.es

Disponible en Internet:

www.seq.es

\section{- Copyright 2021 \\ Sociedad Española de \\ Quimioterapia}

Reservados todos los derechos. Queda rigurosamente prohibida, sin la autorización escrita del editor, la reproducción parcial o total de esta publicación por cualquier medio $o$ procedimiento, comprendidos la reprografía y el tratamiento informático, y la distribución de ejemplares mediante alquiler 0 préstamo públicos, bajo las sanciones establecidas por la ley

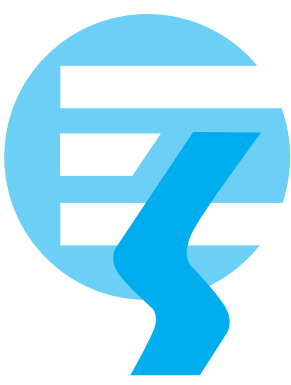

\section{Sociedad Española de Quimioterapia}

Publicidad y Suscripciones

Sociedad Española de Quimioterapia Dpto. de Microbiología

Facultad de Medicina

Avda. Complutense, s/n

28040 Madrid

Atención al cliente

Teléfono 913941512

Correo electrónico

info@seq.es

Consulte nuestra página web www.seq.es
Publicación que cumple los requisitos de soporte válido

ISSN

0214-3429

e-ISSN

1988-9518

Depósito Legal

M-32320-2012

Maquetación

Vic+DreamStudio

Impresión

España

Esta publicación se imprime en papel no ácido. This publication is printed in acid free paper.

LOPD

Informamos a los lectores que, según lo previsto en el Reglamento General de Protección de Datos (RGPD) 2016/679 del Parlamento Europeo, sus datos personales forman parte de la base de datos de la Sociedad Española de Quimioterapia (si es usted socio)

Si desea realizar cualquier rectificación o cancelación de los mismos, deberá enviar una solicitud por e-mail a la Sociedad Española de Quimioterapia (info@seq.es) 


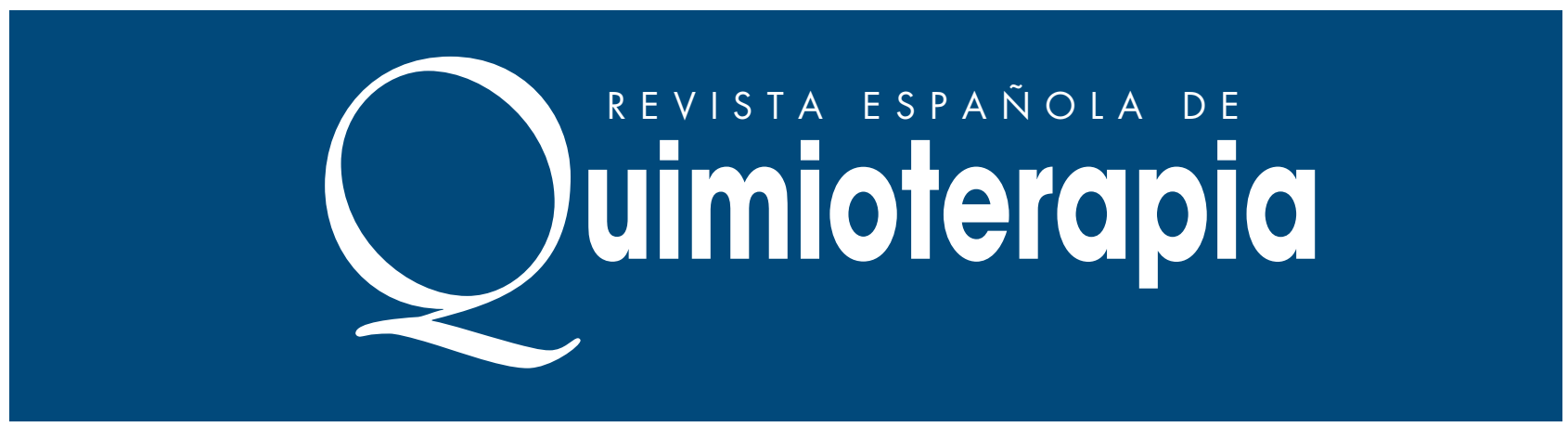

Director

J. Barberán López
Secretario de Redacción

Luis Alou Cervera

Comité Editorial

F. Álvarez Lerma (Barcelona)

F. Baquero Mochales (Madrid)

E. Bouza Santiago (Madrid)

J. A. García Rodríguez (Salamanca)

M. Gobernado Serrano (Valencia)
J. Mensa Pueyo (Barcelona)

J. J. Picazo de la Garza (Madrid)

J. Prieto Prieto (Madrid)

B. Regueiro García (Santiago de Compostela)

A. Torres Martí (Barcelona)

Consejo Editorial

L. Aguilar (Madrid)

J. I. Alós (Madrid)

J. R. Azanza (Pamplona)

J. Aragón (Las Palmas de Gran Canaria)

A. Artero (Valencia)

V. Asensi (Oviedo)

G. Barbeito (Santiago de Compostela)

J. M. Barbero (Madrid)

J. Campos (Madrid)

F.J. Candel (Madrid)

E. Cantón (Valencia)

R. Cantón (Madrid)

J. A. Capdevila Morell

(Barcelona)

M. Casal (Córdoba)

J. Castillo (Zaragoza)

F. Cobo (Granada)

J. Cobo Reinoso (Madrid)

N. Cobos (Madrid)

J. L. del Pozo (Navarra)

R. De la Cámara (Madrid)

C. De la Calle (Barcelona)

M. Dominguez-Gil (Valladolid)

J. Eiros (Valladolid)

P. Escribano (Madrid)

A. Estella (Cádiz)

M. C. Fariñas Álvarez (Santander)

C. Fariñas (Santander)
J. Fortún (Madrid)

J. J. Gamazo (Vizcaya)

E. García Sánchez (Salamanca)

I. García García (Salamanca)

J. E. García Sánchez (Salamanca)

E. Garcia Vázquez (Murcia)

J. Gómez Gómez (Murcia)

M. L. Gómez-Lus (Madrid)

J. González del Castillo (Madrid)

F. González Romo (Madrid)

J. J. Granizo (Madrid)

S. Grau (Barcelona)

J.M. Guardiola (Barcelona)

J. Guinea (Madrid)

X. Guirao (Barcelona)

J. Gutiérrez (Granada)

J. B. Gutiérrez (Córdoba)

B. Isidoro (Madrid)

P. Llinares (La Coruña)

J. E. Losa Garcia (Madrid)

J. R. Maestre Vera (Madrid)

L. Martínez Martínez (Córdoba)

E. Maseda (Madrid)

R. Menéndez (Valencia)

P. Merino (Madrid))

P. Muñoz (Madrid)

J. L. Muñoz Bellido (Salamanca)

V. Navarro (Alicante)
M. Ortega (Barcelona)

J. Oteo (Madrid)

J. A. Oteo (Logroño)

E. Palencia Herrejón (Madrid)

A. Pascual Hernández (Sevilla)

J. Pasquau (Sevilla)

J. Pemán (Valencia)

J. L Pérez-Arellano (Las Palmas)

B. Pérez-Gorricho (Madrid)

A. Ramos (Madrid)

J. M. Ramos (Alicante)

J. Reina (Palma de Mallorca)

M. A. Ripoll (Ávila)

I. Rodriguez-Avial (Madrid)

M. Ruiz (Alicante)

M. Sabriá (Barcelona)

M. Salavert (Valencia)

B. Sánchez Artola (Madrid)

M. Segovia (Murcia)

R. Serrano (Madrid)

D. Sevillano (Madrid)

A. Suárez (Madrid)

A. Tenorio (Huelva)

A. Torres (Murcia)

C. Vallejo (Oviedo)

J. Vila (Barcelona)

J. Yuste (Madrid) 


\section{(1. Xydalbå ${ }_{\text {dalavancina }}$}

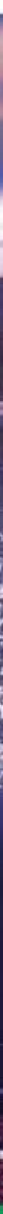

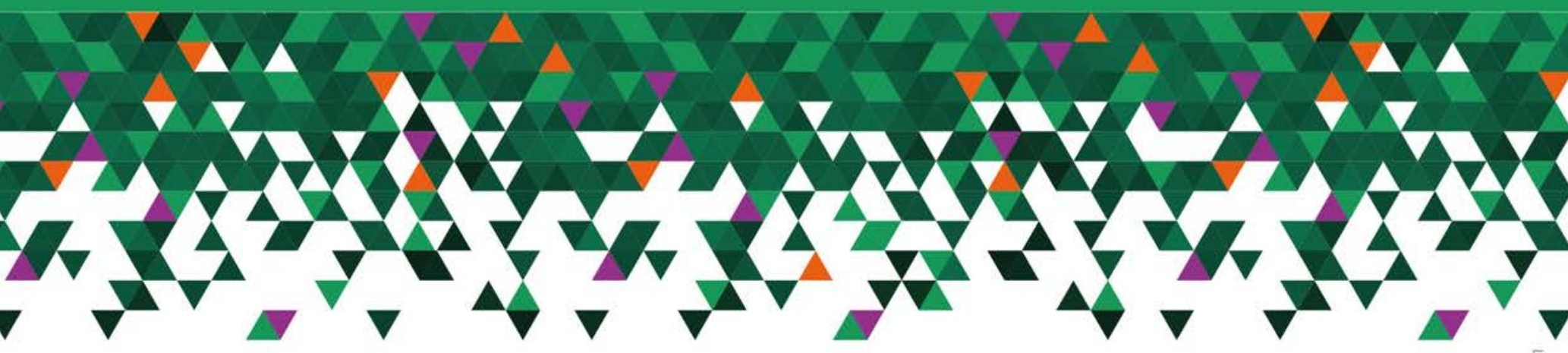

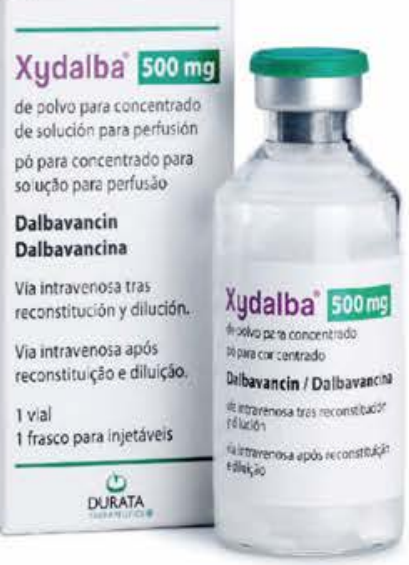

XYDALBA ${ }^{\oplus}$, EL ÚNICO ANTIBIÓTICO QUE PERMITE TRATAR TODO EL CURSO DE LA INFECCIÓN* CON 1 SOLA DOSIS INTRAVENOSA EN 30 MINUTOS $^{1.2}$

Xydalba

* Indicado para el tratamiento de infecciones bacterianas agudas de piel y de los tejidos blandos de la piel en adultos.

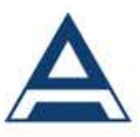

ANGELIN I 


\section{Sumario}

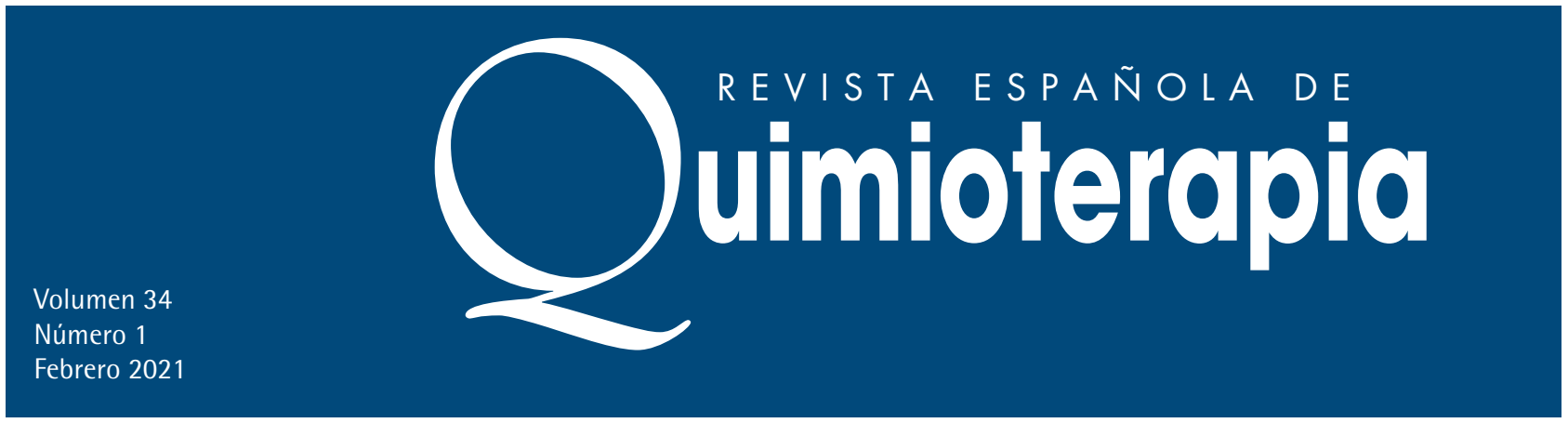

Revisión

Persistencia y viabilidad de SARS-CoV-2 en la primoinfección y reinfecciones 1 Julián Ruiz-Galiana, Pilar de Lucas Ramos, Alejandra García-Botella, Alberto García-Lledó, Javier Gómez-Pavón, Juan González del Castillo, Teresa Hernández-Sampelayo, Mari Cruz MartínDelgado, Francisco Javier Martín Sánchez, Manuel Martínez-Sellés, José María Molero García, Santiago Moreno Guillén, Fernando Rodríguez-Artalejo, Rafael Cantón, Emilio Bouza

Acciones y actitudes ante el paciente inmunizado contra el SARS-CoV-2

Pilar de Lucas Ramos, Alejandra García-Botella, Alberto García-Lledó, Javier Gómez-Pavón, Juan González del Castillo, Teresa Hernández-Sampelayo, Mari Cruz Martín-Delgado, Francisco Javier Martín Sánchez, Manuel Martínez-Sellés, José María Molero Garcia, Santiago Moreno Guillén, Fernando Rodríguez-Artalejo, Julián Ruiz-Galiana, Rafael Cantón, Emilio Bouza

Decalogue for the selection of oral antibiotics for lower respiratory tract infections Rafael Cantón, José Barberán, Manuel Linares, José María Molero,

José Miguel Rodríguez-González-Moro, Miguel Salavert, Juan González del Castillo

Originales

Adecuación a las recomendaciones diagnósticas en pacientes con neumonía por Pneumocystis jirovecii tratados con pentamidina intravenosa Lorenzo Cantarelli, Fernando Gutiérrez Nicolás, Gloria Julia Nazco Casariego, Sara Garcia Gil

La endocarditis infecciosa en un hospital de $2^{\circ}$ nivel: epidemiologia, clínica y análisis de factores pronósticos, con especial referencia a los pacientes trasladados a un hospital de tercer nivel

Ana Isabel Peláez Ballesta, Elisa García Vázquez, Joaquín Gómez Gómez

Código Sepsis: esquivando la mortalidad en un hospital terciario

Rosa Méndez, Angels Figuerola, Marta Chicot, Ana Barrios, Natalia Pascual, Fernando Ramasco, Diego Rodríguez, Iñigo García, Andrés Von Wernitz, Nelly Zurita, Auxiliadora Semiglia, David Jiménez, Sara Navarro, María José Rubio, Mercedes Vinuesa, Lourdes del Campo, Azucena Bautista, Alberto Pizarro

Poder pronóstico de mortalidad a corto plazo del receptor soluble activador del plasminógeno tipo uroquinasa (suPAR) en los pacientes atendidos en urgencias por infección

Rafael Rubio Díaz, Elena de Rafael González, Esther Martín Torres, Elena Valera Núñez, Aurora María López Martos, David Melguizo Melguizo, Maria Piedad Picazo Perea, Pedro Jesús López García, Patricia Fuentes Bullejos, Matilde Chafer Rudilla, Julián Fabián Carretero Gómez, María Carmen Lorenzo Lozano, Agustín Julián-Jiménez

Comorbilidades de los pacientes con COVID-19 atendidos en Atención Primaria 63 durante la primera oleada de la pandemia de SARS-CoV-2 en la Comunidad de Madrid José-Luis Puerta, Macarena Torrego-Ellacuria, Ángel del Rey-Mejías, César Biénzobas López

Originales breves

Impacto de la pandemia COVID-19: Modelo de atención farmacéutica compartida comunitaria y hospitalaria. Satisfacción y aceptabilidad de pacientes con infección $\mathrm{VIH}$ en tratamiento antirretroviral 


\section{Sumario}

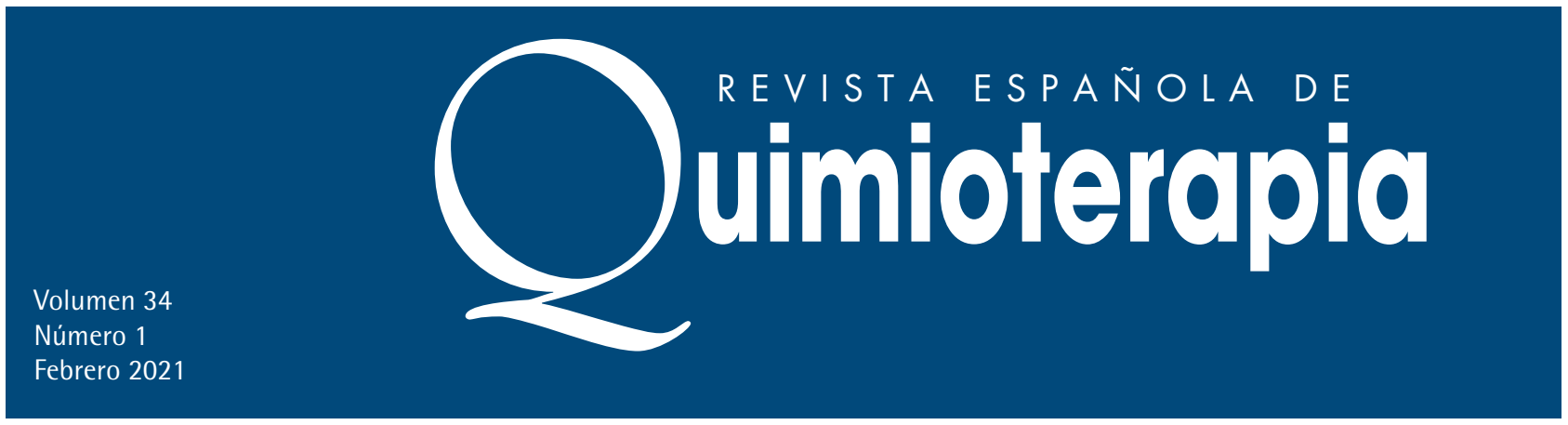

Originales breves

Mycoplasma genitalium en el renovado diagnóstico de las infecciones de

transmisión sexual: evidencias y cifras en un hospital terciario

Gloria Martin-Saco, Alexander Tristancho, Antonina Arias, Isabel Ferrer, Ana Milagro, Juan M.

García-Lechuz

Impacto del SARS-CoV-2 en el diagnóstico de bacteriemia comunitaria en un hospital terciario

Saray Mormeneo Bayo, Miguel Moreno Hijazo, María Pilar Palacián Ruíz, María Cruz Villuendas Usón Lucia Chaves Blanco, Cristina Gómez-Camarasa, Marta Illescas López, Natalia Chueca Porcuna, Laura L. Rojas-García

Un paciente con mal de Pott

Edwin U. Suárez, Silvia Calpena, Beatriz Álvarez, Miguel Górgolas, Raúl Córdoba

Informe de prevalencia de infecciones de transmisión sexual en embarazadas asintomáticas menores de 25 años en Lleida, España

Alba Muñoz Santa, Alba Bellés Bellés, Eric López González, Iván Prats Sánchez, Saray Mormeneo Bayo, Albert Bernet Sánchez, Jesús Aramburu Arnuelos, Maria Font Font, Lucía Fraile García, Mercè Garcia González

Rendimiento del ensayo de amplificación mediada por transcriptasa (TMA) Procleix SARS-CoV-2 para el diagnóstico de COVID-19 en "pools" de muestras nasofaríngeas. Pequeño estudio piloto Marta Pérez-Abeledo, Belén Ramos, Francisco Javier Candel, Juan Carlos Sanz 


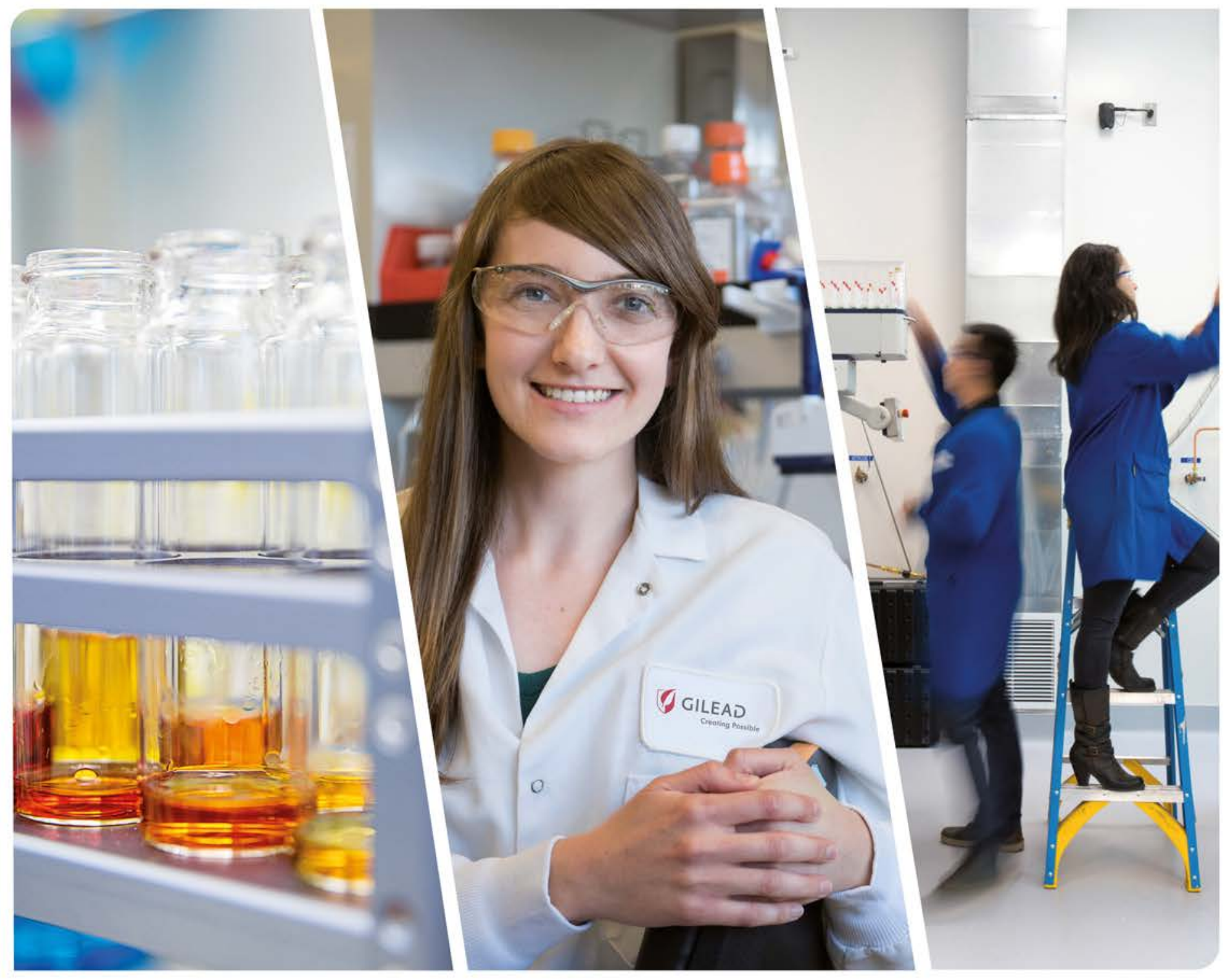

\section{Creating Possible}

Durante más de 30 años, en Gilead hemos conseguido avances que parecían imposibles, dirigidos a personas con enfermedades que amenazaban su vida. Somos una compañía biofarmacéutica puntera, con productos pioneros en sus áreas y con una, cada vez más, prometedora cartera de medicamentos en investigación.

Pero nuestro compromiso aún va más allá. Innovamos con el propósito de eliminar barreras y conseguir que las personas que más lo necesitan puedan tener acceso a los avances en el cuidado de la salud. Trabajamos para conseguir un mundo mejor y más saludable para todos. 


\section{Contents}

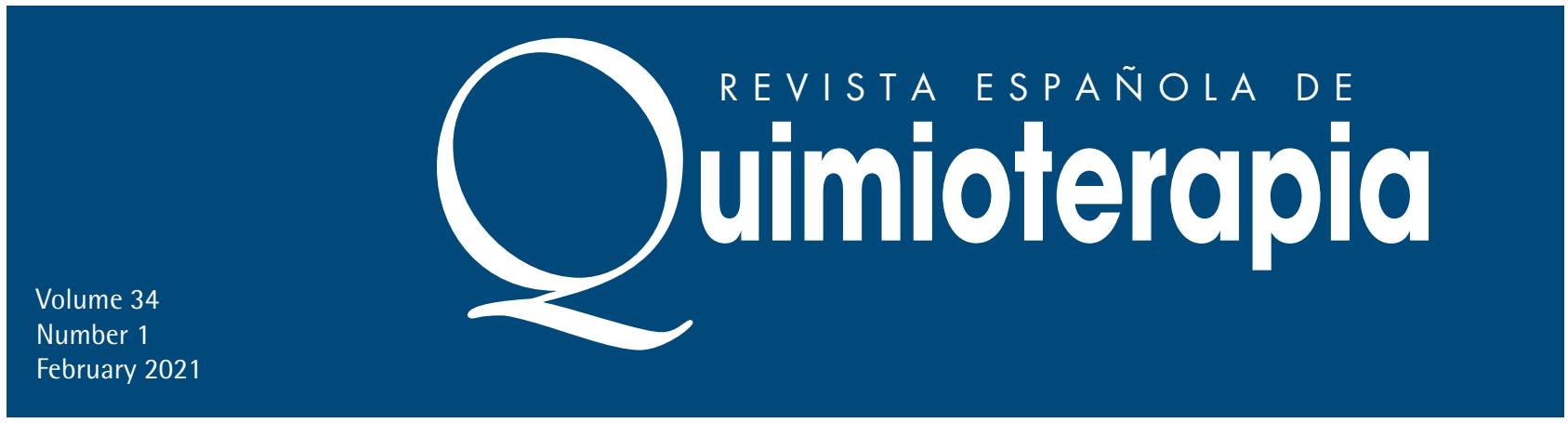

Review

Persistence and viability of SARS-CoV-2 in primary infection and reinfections 1 Julián Ruiz-Galiana, Pilar de Lucas Ramos, Alejandra García-Botella, Alberto García-Lledó, Javier Gómez-Pavón, Juan González del Castillo, Teresa Hernández-Sampelayo, Mari Cruz MartínDelgado, Francisco Javier Martín Sánchez, Manuel Martínez-Sellés, José María Molero García, Santiago Moreno Guillén, Fernando Rodriguez-Artalejo, Rafael Cantón, Emilio Bouza

Actions and attitudes on the immunized patients against SARS-CoV-2

Pilar de Lucas Ramos, Alejandra Garcia-Botella, Alberto García-Lledó, Javier Gómez-Pavón, Juan González del Castillo, Teresa Hernández-Sampelayo, Mari Cruz Martín-Delgado, Francisco Javier Martín Sánchez, Manuel Martínez-Sellés, José María Molero Garcia, Santiago Moreno Guillén, Fernando Rodríguez-Artalejo, Julián Ruiz-Galiana, Rafael Cantón, Emilio Bouza

Decalogue for the selection of oral antibiotics for lower respiratory tract infections Rafael Cantón, José Barberán, Manuel Linares, José María Molero, José Miguel RodríguezGonzález-Moro, Miguel Salavert, Juan González del Castillo

Originals Adequacy to diagnostic recommendations in patients with Pneumocystis jirovecii 30 pneumonia treated with intravenous pentamidine Lorenzo Cantarelli, Fernando Gutiérrez Nicolás, Gloria Julia Nazco Casariego, Sara García Gil

Infective endocarditis treated in a secondary hospital: epidemiological, clinical, microbiological characteristics and prognosis, with special reference to patients transferred to a third level hospital

Ana Isabel Peláez Ballesta, Elisa García Vázquez, Joaquín Gómez Gómez

Sepsis Code: dodging mortality in a tertiary hospital

Rosa Méndez, Angels Figuerola, Marta Chicot, Ana Barrios, Natalia Pascual, Fernando Ramasco, Diego Rodríguez, Iñigo Garcia, Andrés von Wernitz, Nelly Zurita, Auxiliadora Semiglia, David Jiménez, Sara Navarro, María José Rubio, Mercedes Vinuesa, Lourdes del Campo, Azucena Bautista, Alberto Pizarro

Prognostic power of soluble urokinase plasminogen activator receptor (suPAR) for short-term mortality in patients seen in Emergency Departments due to infections Rafael Rubio Díaz, Elena de Rafael González, Esther Martín Torres, Elena Valera Núñez, Aurora María López Martos, David Melguizo Melguizo, María Piedad Picazo Perea, Pedro Jesús López García, Patricia Fuentes Bullejos, Matilde Chafer Rudilla, Julián Fabián Carretero Gómez, Maria Carmen Lorenzo Lozano, Agustín Julián-Jiménez

Comorbidities of Primary Care patients with COVID-19 during the first wave of the SARS-CoV-2 pandemic in the Community of Madrid José-Luis Puerta, Macarena Torrego-Ellacuría, Ángel del Rey-Mejías, César Biénzobas López care model. Satisfaction and acceptability of patients with HIV infection on antiretroviral treatment 


\section{Contents}

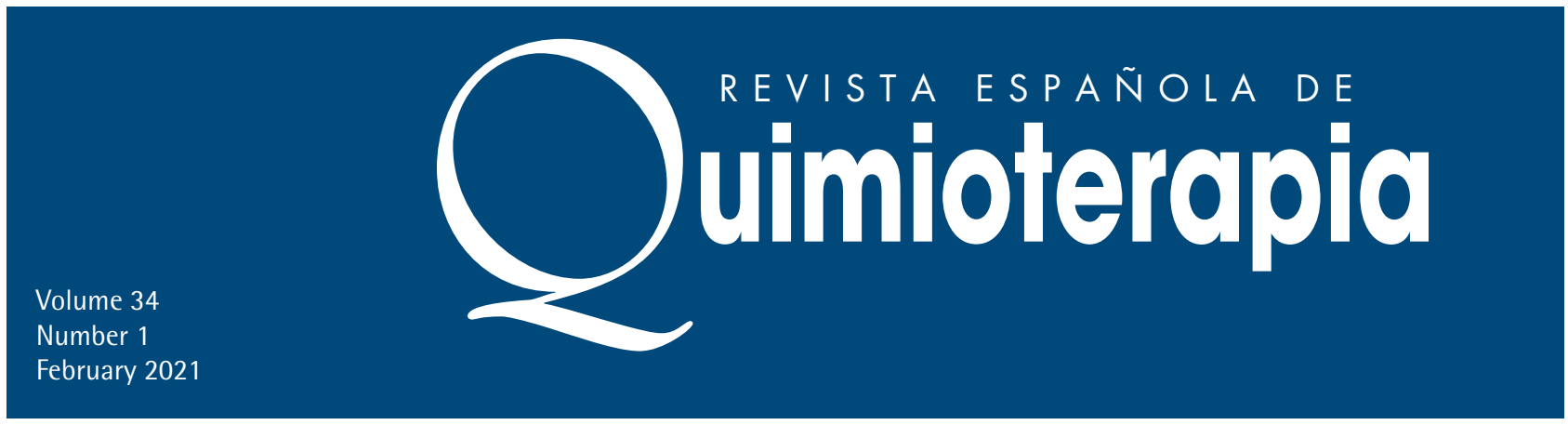

Brief report

Mycoplasma genitalium and sexually transmitted infections: evidences and figures

76

in a tertiary hospital

Gloria Martin-Saco, Alexander Tristancho, Antonina Arias, Isabel Ferrer, Ana Milagro, Juan M.

García-Lechuz

Impact of SARS-COV-2 on the diagnosis of community bacteremia in a tertiary hospital

Saray Mormeneo Bayo, Miguel Moreno Hijazo, María Pilar Palacián Ruíz, Maria Cruz Villuendas Usón

Letters to the editor
Management of cutaneous and systemic involvement by Candida auris

84

Celia Roig Martí, José Javier Jiménez Sierra, Ignacio Pérez Catalán, Barbará Gomila Sard, Alejandro Cardenal Álvarez, María Dolores Bellés Medall

SARS-CoV-2 infection presenting as acute acalculous cholecystitis

Fernando Berdugo Hurtado, Emilio Guirao Arrabal, Andrés Barrientos Delgado, Antonio José Ruiz Rodríguez

Froin's syndrome secondary to epidural abscess

María del Pilar Aguilar Jaldo, David Vinuesa Garcia, Emilio Guirao Arrabal

A rare case of cardiac alveolar echinococcosis without any complications for eight years

Didem Çelik, İlker Ödemiș, Metin Korkmaz, Șükran Köse

Unusual isolation of Pseudoglutamicibacter cumminsii in urine culture

Lucía Chaves Blanco, Cristina Gómez-Camarasa, Marta Illescas López, Natalia Chueca Porcuna, Laura L. Rojas-García

A patient with Pott's disease

Edwin U. Suárez, Silvia Calpena, Beatriz Álvarez, Miguel Górgolas, Raúl Córdoba

Report of sexually transmitted infections prevalence in asymptomatic pregnant 100 women under 25 years old in Lleida, Spain

Alba Muñoz Santa, Alba Bellés Bellés, Eric López González, Iván Prats Sánchez, Saray Mormeneo Bayo, Albert Bernet Sánchez, Jesús Aramburu Arnuelos, Maria Font Font, Lucía Fraile Garcia, Mercè Garcia González

Performance of the Procleix SARS-CoV-2 transcriptase-mediated amplification (TMA) assay for the diagnosis of COVID-19 in nasopharyngeal sample pools.

Small pilot study.

Marta Pérez-Abeledo, Belén Ramos, Francisco Javier Candel, Juan Carlos Sanz 


\section{$\nabla$ VABOREM ${ }^{\circ}$ meropenem/vaborbactam}

\section{¿SOSPECHA DE CRE-KPC? UNA NUEVA Y VALIOSA OPCIÓN PARA CRE.}

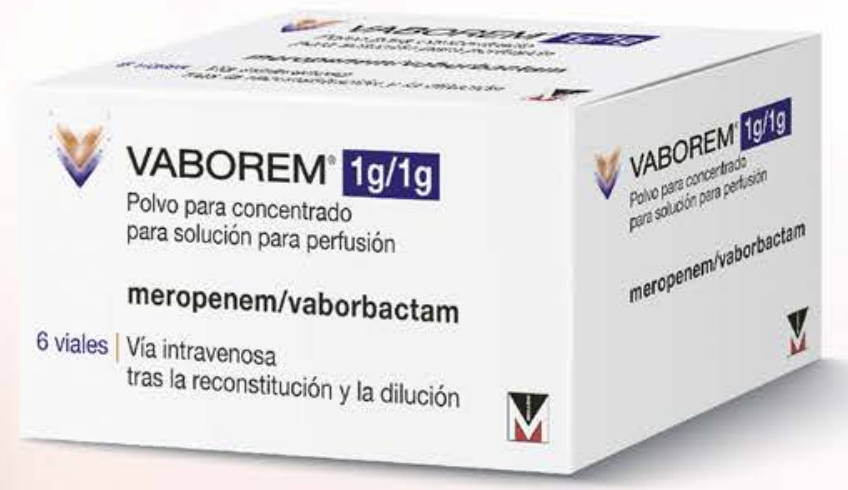

$\nabla$ Este medicamento está sujeto a seguimiento adicional, es prioritaria la notificación de sospechas de reacciones adversas asociadas a este medicamento.

1. Wunderink RG, Giamarellos-Bourboulis EJ, Rahav G, et al. Effect and Safety of Meropenem-Vaborbactam versus Best-Available Therapy in Patients with Carbapenem-Resistant Enterobacteriaceae Infections: The TANGO II Randomized Clinical Trial. Infect Dis Ther 2018;7:439-455.

Para un uso correcto ver Ficha Técnica:

www.menarini.es/fts/vaborem/ 
Julián Ruiz-Galiana' Pilar De Lucas Ramos² Alejandra Garcia-Botella ${ }^{3}$ Alberto García-Lledó ${ }^{4}$ Javier Gómez-Pavón ${ }^{5}$ Juan González del Castillo ${ }^{6}$ Teresa HernándezSampelayo ${ }^{7}$ Mari Cruz Martín-Delgado ${ }^{8}$ Francisco Javier Martín Sánchez ${ }^{9}$ Manuel Martínez-Sellés ${ }^{10}$ José Maria Molero Garcia ${ }^{11}$ Santiago Moreno Guillén ${ }^{12}$ Fernando RodríguezArtalejo ${ }^{13}$ Rafael Cantón ${ }^{14}$ Emilio Bouza ${ }^{15}$

\section{Persistence and viability of SARS-CoV-2 in primary infection and reinfections}

\author{
${ }^{1}$ Internal Medicine Service. Ruber International Hospital. Madrid. \\ ${ }^{2}$ Emeritus. Pneumology Service. Gregorio Marañón General University Hospital, Complutense University. Madrid \\ ${ }^{3}$ General Surgery Service. San Carlos University Clinical Hospital. Complutense University. Madrid. \\ ${ }^{4}$ Cardiology Service. Prince of Asturias Hospital. University of Alcalá. Madrid. \\ ${ }^{5}$ Geriatrics Service. Central Hospital of the Red-Cross. Alfonso X el Sabio University. Madrid. \\ ${ }^{6}$ Emergency Service. San Carlos University Clinical Hospital. Complutense University. Madrid. \\ ${ }^{7}$ Emeritus, Pediatrtics and ACES Service. Gregorio Marañón General University Hospital, Complutense University. Madrid. \\ ${ }^{8}$ Intensive Medicine Service. Torrejón University Hospital. Francisco de Vitoria University. Madrid. \\ ${ }^{9}$ Geriatrics Service. San Carlos University Clinical Hospital. Complutense University. Madrid. \\ ${ }^{10}$ Cardiology Service. Gregorio Marañón General University Hospital, European University. Madrid. \\ ${ }^{11}$ Family Medicine. Infectious diseases. Madrid. \\ ${ }^{12}$ Infectious Diseases Service. Ramón y Cajal Hospital. University of Alcalá de Henares. Madrid. \\ ${ }^{13}$ Department of Public Health. Autonomous University. Madrid. \\ ${ }^{14}$ Microbiology Service. Ramón y Cajal Hospital and Ramón y Cajal Institute for Health Research (IRYCIS). Spanish \\ Network for Research in Infectious Pathology (REIPI). Madrid. \\ ${ }^{15}$ Clinical Emeritus, Community of Madrid. Clinical Microbiology and Infectious Diseases Service of the Gregorio \\ Marañón General University Hospital, Complutense University. CIBERES. Cyber of Respiratory Diseases. Madrid.
}

Article history

Received: 16 September 2021; Accepted: 9 October 2021; Published: 18 October 2021

\section{ABSTRACT}

Since the beginning of the SARS-CoV-2 epidemic, virus isolation in the infected patient was only possible for a short period of time and it was striking that this occurred constantly and did not provide guidance on the clinical course. This fact led to confusion about the efficacy of some of the drugs initially used, which seemed to have a high efficiency in viral clearance and proved ineffective in modifying the course of the disease. The immune response also did not prove to be definitive in terms of evolution, although most of the patients with very mild disease had a weak or no antibody response, and the opposite was true for the most severe patients.

With whatever the antibody response, few cases have been re-infected after a first infection and generally, those that have, have not reproduced a spectrum of disease similar to the first infection. Among those re-infected, a large number have been asymptomatic or with very few symptoms, others have had a moderate picture and very few have had a poor evolution.

Despite this dynamic of rapid viral clearance, laboratory tests were still able to generate positive results in the recovery of genomic sequences and this occurred in patients who were already symptom-free, in others who were still ill and in those who were very seriously ill. There was also no good correlate.

Correspondence:

Emilio Bouza Servicio de Microbiología Clinica y Enfermedades Infecciosas del Hospital General Universitario Gregorio Marañón, Universidad Complutense. CIBERES. Ciber de Enfermedades Respiratorias. Madrid

E-mail: emilio.bouza@gmail.com

All authors belong to the Scientific Committee on COVID-19 of the Madrid College of Physicians (ICOMEM).
For this reason and with the perspective of this year and the half of pandemic, we compiled what the literature leaves us in these aspects and anticipating that, as always in biology, there are cases that jump the limits of the general behavior of the dynamics of infection in general.

Keywords: COVID-19, Viral dynamics, Viral genetic material recovery, Reinfection, SARS-CoV-2, PCR Persistence

\section{Persistencia y viabilidad de SARS-CoV-2 en la primoinfección y reinfecciones}

\section{RESUMEN}

Desde el inicio de la epidemia por SARS-CoV-2, el aislamiento del virus en el paciente infectado era posible solo durante un periodo corto de tiempo y llamaba la atención que esto ocurría de una manera constante y no orientaba sobre la evolución clínica. Este hecho, indujo a confusión sobre la eficacia de algunos de los fármacos utilizados inicialmente que parecian tener una gran eficiencia en el aclarado viral y que resultaron ineficaces para modificar el curso de la enfermedad. La respuesta inmune tampoco se mostraba definitiva para aventurar la evolución aunque la mayoría de los pacientes que tenian una enfermedad muy leve, tenían una débil o nula respuesta de anticuerpos y en los más graves pasaba lo contrario.

Con cualquiera que haya sido la respuesta de anticuerpos, pocos casos han vuelto a infectarse tras una primo-infección y generalmente, los que lo han hecho, no han reproducido un espectro de enfermedad similar a la primera infección. Entre los re-infectados, gran parte han sido asintomáticos o con 
muy pocos sintomas, otros han tenido un cuadro moderado y muy pocos han tenido mala evolución.

Pese a esa dinámica de rápido aclaramiento viral, las pruebas de laboratorio podian seguir siendo capaces de generar positivos en la recuperación de secuencias genómicas y esto ocurría en pacientes libres ya de sintomas, en otros que seguían enfermos y en los muy graves. Tampoco había un buen correlato.

Por eso y con la perspectiva de este año y medio de pandemia recopilamos lo que nos deja la literatura en estos aspectos adelantando que, como siempre en biología, existen casos que saltan los límites del comportamiento general de la dinámica de la infección en general.

Palabras clave: COVID-19, Dinámica viral, Recuperación de material genético viral, Reinfección, SARS-CoV-2, Persistencia de PCR.

\section{INTRODUCTION}

Since the beginning of the SARS CoV2 infection pandemic, the scientific world has wondered about the pathogenesis of the disease, the persistence of viable viruses, the duration of transmissibility, and the risk of reinfection. Diagnostic tests based on the presence of nucleic acids persisted positive in some patients for weeks and even months and it took a certain period of time to demonstrate their dissociation with viral viability.

Over time, some unknowns such as those mentioned have been cleared up, but others such as the duration of immunity, vaccine efficacy, the risk of longer-term reinfections and the clinical forms of second infections appear.

The Committee on COVID of the Illustrious College of Physicians of Madrid, has received questions both about the persistence of the viral presence during primary infection and about reinfections that it has tried to answer after multidisciplinary discussions.

This document collects the questions received and the answers that in the current state of knowledge we have been able to offer.

\section{WHAT ARE THE VIRAL DYNAMICS IN PRIMARY SARS-CoV-2 INFECTION AND THE SIGNIFICANCE OF MICROBIOLOGICAL TESTS DURING THE CLINICAL COURSE?}

It is very well documented that, after the acquisition of the virus, the replicative curve and the consequent viral load has a great rise between the second and third day before the onset of symptoms, reaching their zenith immediately before and in the first week of the disease, to decrease in the following days [1-4].

The microbiological data on virus recovery, RNA quantification and pathogenic viability in cell line cultures reflect and are consistent with the transmission capacity and infectivity collected in epidemiological and observational studies during the pandemic $[5,6]$.
The recovery of viable viruses is estimated in 8 days after the onset of symptoms and the rate of RT-PCR cycles that suggest viral viability is estimated in equal or less than 28 .

Immunosuppression is a conditioning factor that may prolong this time window, being exceptional in these cases a lapse of more than 20 days $[3,7]$. On the other hand, the clinical severity of the disease conditions the immune response and it is not clear if conditions also the viral dynamics [8].

Forty-four per cent of infections occur before the onset of symptoms [5] and in general, there is no transmission capacity from the tenth day of the onset of the disease. In fact, quarantine recommendations have been made for those infected with this criterion [9]. This does not mean that viral RNA cannot be recovered from organic samples beyond this period.

There are many studies that establish the re-positivity of RT-PCR in recovered patients, even those who had previously made the test negative. In a review of these series [10], figures ranging from $2.4 \%$ to the highest of $69.2 \%$ are given and with intervals from discharge from 1 to 38 days and up to 82 days after the onset of symptoms. The vast majority of patients are asymptomatic, but in some of these studies, up to $44.7 \%$ have some mild symptoms of those related to acute COVID; few have a worse course of the disease and some die [10-12].

The factors that determine this re-positivization (viral genetic material, viable or not), and its meaning (genome remains; viral persistence or even reactivation and finally reinfection) is determined by multiple factors, some of which are independent of the disease proper biology, such as technical errors (false negatives, false positives) and cross reactions with other coronaviruses.

Others depend on the biology of the virus itself, such as the initial viral load $[13,14]$, the possible intermittent excretion or the different persistence time of the new variants [15]. Also, on the type of organic samples analyzed (high or low respiratory secretions, blood, feces) $[4,16]$.

Finally, determining factors of the patient. The immune status is shown as a very determining factor, as well as the medications received and age.

Improving knowledge of the viral dynamics and its modifications with the different variants and with the immune response is essential to be able to speak with greater conviction about persistence, reactivation or recurrence and reinfection and to be able to sustain the quarantine recommendations for patients on recovery of the primary infection in the successive phases of the epidemic.

\section{HOW MUCH AND WHAT DOES REINFECTION WITH SARS-CoV-2 INVOLVE?}

Reinfection, defined as the positivization of the RT-PCR, beyond three months after the primary infection, (definition accepted in the literature) whether with clinical symptoms or not, is another face of the SARS-CoV-2 disease, well documented.

Considering reinfection with a criterion of microbiological as well as clinical certainty, goes beyond simply re-positivizing 
the RT-PCR. It requires demonstrating by genetic sequencing that the first and second episode viruses have a sufficiently different structure from what might be expected based on the mutation rate of the original inoculum. That is, to confirm that we are dealing with a differentiated clone or a phylogenetically different virus. Unviable demonstration in the day-to-day of most healthcare structures [17-20].

We know that with SARS-CoV-2 there is an early drop in antibodies titer, including low or no generation in mild clinical conditions $[13,22]$, although there are more and more studies that measure neutralizing antibodies (anti-S) and provide data on longer duration of these than ordinarily we titrate them in the standard clinical follow-up tests, suggesting that there may be a more durable protection than we initially intuited and more consistent with the reality of the observations $[23,24]$.

Added to this is the large number of patients who passed the primary infection asymptomatic and unnoticed (figures up to 10 times the clinically documented according to serological prevalence studies). Likewise, the casual observation in asymptomatic samples of RT-PCR positivity in subjects who have already passed the disease and are outside the known time frame for viral persistence or its genomic fragments.

In addition to the drip of communication of cases with the certainty of being faced with a different virus, and therefore defining reinfection [25-32], studies are appearing that focus the estimates of reinfection.

There is a Danish series of observational follow-up of a long court of infected with positive RT-PCR in the first months of the pandemic (until June 20), and measure how many of these are re-infected (September to December 20), 0.65\% of them did.

A parallel cohort of not infected in the first wave, positivized up to $3.25 \%$. The work shows that the primary infection generates an important but not total protection [33].

Austria has a retrospective observational epidemiological study along the same lines and, taking into account the weaknesses of these measurements, it gives equivalent figures in a proportion of $0.27 \%$ of reinfections and 2.85 of new infections in the second wave [34].

The British SIREN study performs clinical, serological and microbiological monitoring of two large cohorts of health personnel (younger and with greater exposure). One cohort with proven primary infection and another virgin to the infection. They once again demonstrate accumulated incidences of new infections in similar ratios (0.5\% and 2.2\% respectively). Again, significant protection is evidenced after natural infection, at least up to 5 months, but not complete. The study makes a comparison with what is known about vaccines and equates their protection to that of natural infection [35].

Italy, confirms reinfection rates of $0.31 \%$, with a mean follow-up interval of 230 days, in Lombardy, one of its most severely affected regions at the beginning of the epidemic. This incidence of infection is 13 times lower than that of the virgin population [36].
The United States provides another interstate series, based on a database of $3,257,478$ persons with conventional serology performed (11.6\% positive and $88.6 \%$ negative and 0.1\% doubtful) and studies the number of PCR positives at an average follow-up time of 390 days per person and again shows infection rates of $0.3 \%$ for those initially serologically positive and $3 \%$ for those negative [37].

These repeatedly similar figures confirm, with different methodologies, a significant protection at least one year after immunization.

Reinfection considered only from a clinical point of view is a fact that is attended on time and with many probabilities that the frequency with which we see it is much lower than what happens in reality due to considerations of inadvertent disease, both for the first as for the second episode and the demonstrative figures from these observational studies.

The literature recognizes this and there are proposals to diagnose reinfection with clinical criteria [38].

The new variants enter fully into reinfections and their clinical behavior and do so fundamentally due to their higher prevalence in a geographical location and at a specific time. The Marseille series is very demonstrative in this sense, confirming the British variant in reinfection and the initial Wuhan variant in the primary infection of its cases [39].

The biological advantages of infectivity and the possibility of escape from the previous immune response are determining factors, although at the moment the conjecture of laboratory studies of the neutralizing capacity of the sera of convalescent or post-vaccination patients is more than the real epidemiological evidence [35, 40-45].

We are already in a time of epidemic, in which it should become mandatory, at least in healthcare environments of medium complexity, to have, together with the RT-PCR positivity, more information on the strains found and the viral load or the cycle threshold obtained. We should process more samples and make a greater clinical, laboratory and immuno-microbiological follow-up of those infected. Naturally in controlled and not indiscriminate studies.

Only then, when we accumulate series with more documentation after the disease produced by the different variants, the immune response to these and after the administration of the different vaccines, can solid conclusions be drawn about the natural history of COVID-19 and the effectiveness of protection.

Now we cannot even ensure that natural infection conditions a greater defense than vaccines for reinfection.

\section{WHAT DOES REINFECTION LOOK LIKE CLINICALLY AND HOW IS THE IMMUNITY?}

There are asymptomatic (most), some mild cases and others more severe than the first episode, even with a fatal evolution $[28,29]$.

The possibility of an inflammatory potentiation mediated by the preexistence of antibodies is once again raised [38]. Im- 
munosuppression is once again an evolutionary risk in reinfection $[29,43]$.

Regarding what we know about the immune status of the reinfected people, in most cases, serologies were not available after the first episode, in others it had become negative even though they had responded. Others had an adequate immune response even with neutralizing antibodies. Not enough information is available regarding specifically this type of anti-S antibodies and their protective quantification criteria.

What seems clear is that practically everyone makes an adequate antibody response in the first week of reinfection and this suggests that there is a cell population with memory that facilitates the rapid response.

In some cases, neutralizing antibodies are measured in the nasopharyngeal mucosa in the first week after reinfection [31].

Epidemiologically, it seems that there is a greater risk of greater exposure, as is the case with health-care workers.

Regarding the transmission capacity of the reinfected people, there is also little epidemiological data that they behave as index cases, although some reappear in small outbreaks.

Therefore, for the purposes of clinical care and protection against transmission, reinfection should be treated in the same way as primary infection.

\section{WHAT CAN BE THE FUTURE OF REINFECTIONS?}

It is possible to speculate on the future evolution of reinfections, but in the light of our current knowledge, we can only assure that in the last months the work on reinfection remains in similar figures to those mentioned and the difference is the time lapse between the first and the second infection. It must be taken into account that there will be a very determining factor and it is the prevalence of the virus in the following months. If it continues to fall, both primary and reinfection will be lower. Vaccines are proving to be effective in this attenuation of the epidemic. The role of viral variants will be decisive because of their prevalence at a given time and their potential role in immune escape. Vaccines will again be essential to curb both aspects.

\section{CONCLUSIONS}

The reproduction dynamics of SARS-CoV-2 in human infection reaches its peak at the beginning of the symptoms of the disease, with a subsequent decrease that makes its transmission to be minimal from the $8^{\text {th }}$ day of the disease.

Viral genome recovery techniques can remain positive for up to three months, being remains unviable for transmission.

During this immediate period after the primary infection, reactivations of symptoms associated with the acute disease are described, including some cases with poor clinical evolution. It is difficult to differentiate what are complications of the initial phase, viral reactivation in its interaction with the infected host or even reinfections.

Re-infection after this three-month period is rare (less than 1\%), but possible, even in the five-month period of greatest protection. All this considering that all our references are produced in the first year of the epidemic.

In general, reinfection is asymptomatic or very benign, but it can behave like the primary infection, be more serious and even fatal.

New variants can change what has already been described. It is probable that doing more extensive microbiological and serological follow-up series to those already infected will show upward the possibility of reinfection.

Serological follow-up studies with measurement of neutralizing antibodies are beginning to appear, which equate the protection of natural infection with that granted by vaccines

\section{FUNDING}

None to declare

\section{CONFLICTS OF INTEREST}

The authors declare no conflicts of interest

\section{REFERENCES}

1. Wölfel $R$, Corman VM, Guggemos W, Seilmaier M, Zange $S$, Müller $M A$, et al. Virological assessment of hospitalized patients with COVID-2019. Nature. 2020 May;581(7809):465-469. doi: 10.1038/ s41586-020-2196-X.

2. He $X$, Lau EHY, Wu P, Deng $X$, Wang J, Hao $X$, et al. Temporal dynamics in viral shedding and transmissibility of COVID-19. Nat Med. 2020;26(5):672-675. doi: 10.1038/s41591-020-0869-5.

3. van Kampen JJA, van de Vijver DAMC, Fraaij PLA, Haagmans BL, Lamers MM, Okba N, et al. Duration and key determinants of infectious virus shedding in hospitalized patients with coronavirus disease-2019 (COVID-19). Nat Commun. 2021;12(1):267. doi: 10.1038/s41467-020-20568-4.

4. Cevik M, Tate M, Lloyd O, Maraolo AE, Schafers J, Ho A. SARSCOV-2, SARS-COV, and MERS-CoV viral load dynamics, duration of viral shedding, and infectiousness: a systematic review and meta-analysis. Lancet Microbe. 2021 Jan;2(1):e13-e22. doi: 10.1016/ S2666-5247(20)30172-5.

5. Cheng HY, Jian SW, Liu DP, Ng TC, Huang WT, Lin HH; Taiwan COVID-19 Outbreak Investigation Team. Contact Tracing Assessment of COVID-19 Transmission Dynamics in Taiwan and Risk at Different Exposure Periods Before and After Symptom Onset. JAMA Intern Med. 2020;180(9):1156-1163. doi: 10.1001/jamainternmed.2020.2020

6. Kim MC, Cui C, Shin KR, Bae JY, Kweon OJ, Lee MK, et al. Duration of Culturable SARS-CoV-2 in Hospitalized Patients with Covid-19. 
N Engl J Med. 2021;384(7):671-673. doi: 10.1056/NEJMc2027040.

7. Owusu D, Pomeroy MA, Lewis NM, Wadhwa A, Yousaf AR, Whitaker B, et al. Household Transmission Study Team. Persistent SARSCoV-2 RNA Shedding without Evidence of Infectiousness: A Cohort Study of Individuals with COVID-19. J Infect Dis. 2021 Feb 27:jiab107. doi: 10.1093/infdis/jiab107.

8. Legros $V_{1}$ Denolly $S$, Vogrig M, Boson B, Siret E, Rigaill J, et al. A longitudinal study of SARS-CoV-2-infected patients reveals a high correlation between neutralizing antibodies and COVID-19 severity. Cell Mol Immunol. 2021 Feb;18(2):318-327. doi: 10.1038/s41423020-00588-2.

9. CDC. Duration of Isolation and Precautions for Adults with COVID-19. Accessed August 26, 2020, https://www.cdc.gov/coronavirus/2019-ncov/hcp/duration-isolation.htm

10 Dao TL, Hoang VT, Gautret P. Recurrence of SARS-CoV-2 viral RNA in recovered COVID-19 patients: a narrative review. Eur J Clin Microbiol Infect Dis. 2021 Jan;40(1):13-25. doi: 10.1007/s10096020-04088-z.

11. Kang YJ. South Korea's COVID-19 Infection Status: From the Perspective of Re-positive Test Results After Viral Clearance Evidenced by Negative Test Results. Disaster Med Public Health Prep. 2020;14(6):762-764. doi: 10.1017/dmp.2020.168.

12. Gousseff M, Penot P, Gallay L, Batisse D, Benech N, Bouiller K et all. Clinical recurrences of Covid 19 symptoms after recovery: viral relapse, reinfection or inflamatory rebound?. J Infect 2020; 81: 816-846. Doi: 10.1016/j.jin.2020.06.73

13. Zheng J, Zhou R, Chen F, Tang G, Wu K, Li F et al. Incidence, clinical course and risk factors for recurrent PCR positivity in discharged COVID 19 patiens Guangzhou, China: a prospective cohort study. PloS Negl Trop Dis 2020; 14 (8):e0008648. doi: 10.1371/journal. pntd.0008648

14. Guallar MP, Meiriño R, Donat-Vargas C, Corral O, Jouvé N, Soriano $\mathrm{V}$. Inoculum at the time of SARS-CoV-2 exposure and risk of disease severity. Int J Infect Dis. 2020 Aug;97:290-292. doi: 10.1016/j. ijid.2020.06.035.

15. Kissler S, Fauver JR, Mack C, et al. Densely sampled viral trajectories suggest longer duration of acute infection with B.1.1.7 variant relative to non-B.1.1.7 SARS-CoV-2. https://dash.harvard.edu/handle/1/37366884 (Accessed on February 17, 2021).

16. Fontana LM, Villamagna AH, Sikka MK, McGregor JC. Understanding viral shedding of severe acute respiratory coronavirus virus 2 (SARS-CoV-2): Review of current literature. Infect Control Hosp Epidemiol. 2021;42(6):659-668. doi: 10.1017/ice.2020.1273.

17. Callow KA, Parry HF, Sergeant M, Tyrrell DA. The time course of the immune response to experimental coronavirus infection of man. Epidemiol Infect 1990; 105(2): 435-46. doi: 10.1017/ s0950268800048019.

18. Galanti M, Shaman J. Direct Observation of Repeated Infections With Endemic Coronaviruses. J Infect Dis. 2021;223(3):409-415. doi: 10.1093/infdis/jiaa392.

19. Inmunidad del SAR-CovTemperton NJ, Chan PK, Simmons G, et al. Longitudinally profiling neutralizing antibody response to SARS coronavirus with pseudotypes. Emerg Infect Dis 2005; 11(3): 411-

\section{6. doi: 10.3201/eid1103.040906.}

20. Wu LP, Wang NC, Chang YH, et al. Duration of antibody responses after severe acute respiratory syndrome. Emerg Infect Dis 2007; 13(10): 1562-4. doi: 10.3201/eid1310.070576.

21. Rijkers $G$, Murk JL, Wintermans $B$, van Looy $B$, van den Berge $M$, Veenemans J, et al. Differences in Antibody Kinetics and Functionality Between Severe and Mild Severe Acute Respiratory Syndrome Coronavirus 2 Infections. J Infect Dis. 2020; 222(8):1265-1269. doi: 10.1093/infdis/jiaa463

22. Lynch KL, Whitman JD, Lacanienta NP, Beckerdite EW, Kastner SA, Shy BR, et al. Magnitude and kinetics of anti-SARS-CoV-2 antibody responses and their relationship to disease severity. Published online 2020 Jul 14. doi: 10.1093/cid/ciaa979

23. He $Z$, Ren L, Yang J, Guo L, Feng L, Ma C, et al. Seroprevalence and humoral immune durability of anti-SARS-CoV-2 antibodies in Wuhan, China: a longitudinal, population-level, cross-sectional study. Lancet. 2021;397(10279):1075-84. doi: 10.1016/S01406736(21)00238-5.

24. an Elslande J, Gruwier L, Godderis L, Vermeersch P. Estimated halflife of SARS-CoV-2 anti-spike antibodies more than double the half-life of anti-nucleocapsid antibodies in healthcare workers. Clin Infect Dis. 2021 Mar 8:ciab219. doi: 10.1093/cid/ciab219.

25.-. To KK, Hung IF, Ip JD, Chu AW, Chan WM, Tam AR, et al. COVID-19 re-infection by a phylogenetically distinct SARS-coronavirus-2 strain confirmed by whole genome sequencing. Clin Infect Dis. 2020; Aug 25;ciaa1275.doi: 10.1093/cid/ciaa1275.;

26. Van Elslande J, Vermeersch $P$, Vandervoort $K$, Wawina-Bokalanga T, Vanmechelen B, Wollants $E_{1}$ et al. Symptomatic Severe Acute Respiratory Syndrome Coronavirus 2 (SARS-CoV-2) Reinfection by a Phylogenetically Distinct Strain. Clin Infect Dis. 2021 Jul 15;73(2):354-356. doi: 10.1093/cid/ciaa1330.

27. Gupta V, Bhoyar RC, Jain A, Srivastava S, Upadhayay R, Imran M, et al. Asymptomatic reinfection in two healthcare workers from India with genetically distinct SARS-CoV-2. Clin Infect Dis. 2020 Sep 23:ciaa1451. doi: 10.1093/cid/ciaa1451.

28. Tillett RL, Sevinsky JR, Hartley PD, Kerwin H, Crawford N, Gorzalski $A$, et al. Genomic evidence for reinfection with SARS-CoV-2: a case study. Lancet Infect Dis. 2021; 21(1):52-58. doi: 10.1016/S14733099(20)30764-7

29. Mulder M, van der Vegt DSJM, Oude Munnink BB, GeurtsvanKessel $\mathrm{CH}$, van de Bovenkamp J, Sikkema RS, Jacobs EMG, Koopmans MPG, Wegdam-Blans MCA Reinfection of SARS-CoV-2 in an immunocompromised patient: a case report. Clin Infect Dis 2020; Oct 9;ciaa1538. doi: 10.1093/cid/ciaa1538.

30. Lee JS, Kim SY, Kim TS, Hong KH, Ryoo NH, Lee J, et al Evidence of Severe Acute Respiratory Syndrome Coronavirus 2 Reinfection After Recovery from Mild Coronavirus Disease 2019. Clin Infect Dis. 2020 Nov 21:ciaa1421. doi: 10.1093/cid/ciaa1421.

31. Selhorst $P$, Van lerssel $S$, Michiels J, Mariën J, Bartholomeeusen $K_{1}$ Dirinck $E$, et al.. Symptomatic SARS-CoV-2 reinfection of a health care worker in a Belgian nosocomial outbreak despite primary neutralizing antibody response. Clin Infect Dis. 2020 Dec 14:ciaa1850. doi: $10.1093 /$ cid/ciaa1850 
32. To KK, Hung IF, Chan KH, Yuan S, To WK, Tsang DN, et al. Serum Antibody Profile of a Patient With Coronavirus Disease 2019 Reinfection. Clin Infect Dis. 2021 May 18;72(10):e659-e662. doi: 10.1093/cid/ciaa1368.

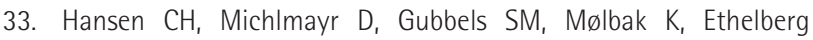
$S$. Assessment of protection against reinfection with SARSCoV-2 among 4 million PCR-tested individuals in Denmark in 2020: a population-level observational study. Lancet. $2021 \mathrm{Mar}$ 27;397(10280):1204-1212. doi: 10.1016/S0140-6736(21)00575-4.

34. Pilz $S$, Chakeri A, loannidis JP, Richter $L$, Theiler-Schwetz V, Trummer $C$, Krause R, Allerberger F. SARS-CoV-2 re-infection risk in Austria. Eur J Clin Invest. 2021 Apr;51(4):e13520. doi: 10.1111/ eci. 13520

35. Hall $V$, Foulkes $S$, Charlett $A$, Atti $A$, Monk EJM, Simmons $R$, et al. Do antibody positive healthcare workers have lower SARSCoV-2 infection rates than antibody negative healthcare workers? Large multi-centre prospective cohort study (the SIREN study), England: June to November 2020 medRxiv preprint doi: 10.1101/2021.01.13.21249642

36. Vitale J, Mumoli N, Clerici P, et al. Assessment of SARS-CoV-2 reinfection 1 year after primary infection in a population in Lombardy, Italy. JAMA Intern Med. Published online May 28, 2021. doi:10.1001/jamainternmed.2021.2959

37. Harvey RA, Rassen JA, Kabelac CA, et al. Association of SARS-CoV-2 seropositive antibody test with risk of future infection. JAMA Intern Med. 2021;181(5):672-679. doi:10.1001/jamainternmed.2021.0366

38. Raveendran AV. COVID 19 re-infection: Diagnostic challenges and proposed diagnostic criteria. Diabetes \&t Metabilic Syndrome: Clinical Research \& Reviews 2021;15:645-648.

39. Brouqui $P$, Colson $P$, Melenotte $C$, Houhamdi $L$, Bedotto $M$, Devaux C, Gautret P, Million M, Parola P, Stoupan D, La Scola B, Lagier JC, Raoult D COVID-19 re-infection. Eur J Clin Invest. 2021 May;51(5):e13537.DOI: 10.1111/eci.13537.

40 Harrington $D$, Kele $B$, Pereira $S$, Couto-Parada $X$, Riddell A, Forbes $\mathrm{S}$, Dobbie H, Cutino-Moguel T. Confirmed Reinfection with SARSCoV-2 Variant VOC-202012/01. Clin Infect Dis. 2021 Jan 9:ciab014. doi: 10.1093/cid/ciab014.

41. Zucman N, Uhel F, Descamps D, Roux D, Ricard JD. Severe reinfection with South African SARS-CoV-2 variant 501Y.V2: A case report. Clin Infect Dis. 2021 Feb 10:ciab129. doi: 10.1093/cid/ciab129

42. Malta Romano C., et al. SARS-CoV-2 reinfection caused by the P.1 lineage in Araraquara city, Sao Paulo State, Brazil. Rev Inst Med Trop Sao Paulo 2021 Apr 23;63: e36. D0I: 10.1590/S16789946202163036. eCollection 2021.

43.- Marquez L, Koy T, Spinler JK, Luna RA, Tocco L, Fasciano L, Dunn J, Campbell JR. Reinfection with Severe Acute Respiratory Syndrome Coronavirus 2 (SARS-CoV-2) B.1.1.7 variant in an immunocompromised adolescent. Infect Control Hosp Epidemiol. 2021 May 3:1-6. DOI: 10.1017/ice.2021.195.

44. Rani PR, Imran M, Lakshmi JV, Jolly B, Jain A, Surekha A, Senthivel $V_{1}$ Chandrasekhar P, Divakar MK, Srinivasulu D, Bhoyar RC, Vanaja PR, Scaria V, Sivasubbu. Symptomatic reinfection of SARS-CoV-2 with spike protein variant N440K associated with immune escape.
S.J Med Virol. 2021 Apr 5. DOI: 10.1002/jmv.26997.

45. Amorim M.R., et al. Respiratory Viral Shedding in Healthcare Workers Reinfected with SARS-CoV-2, Brazil, 2020. Emerg Infect Dis 2021 Apr 19;27(6). DOI: 10.3201/eid2706.210558. 
Pilar De Lucas Ramos ${ }^{1}$ Alejandra Garcia-Botella ${ }^{2}$ Alberto Garcia-Lledó ${ }^{3}$ Javier Gómez-Pavón ${ }^{4}$ Juan González del Castillo ${ }^{5}$ Teresa HernándezSampelayo ${ }^{6}$ Mari Cruz Martín-Delgado ${ }^{7}$ Francisco Javier Martín Sánchez ${ }^{8}$ Manuel Martínez-Sellés ${ }^{9}$ José María Molero García ${ }^{10}$ Santiago Moreno Guillén ${ }^{11}$ Fernando RodríguezArtalejo ${ }^{12}$ Julián Ruiz-Galiana ${ }^{13}$ Rafael Cantón ${ }^{14}$ Emilio Bouza ${ }^{15}$

\section{Actions and attitudes on the immunized patients against SARS-CoV-2}

\author{
Emeritus. Pneumology Service. Gregorio Marañón General University Hospital, Complutense University. Madrid \\ ${ }^{2}$ General Surgery Service. San Carlos University Clinical Hospital. Complutense University. Madrid. \\ ${ }^{3}$ Cardiology Service. Prince of Asturias Hospital. University of Alcalá. Madrid. \\ ${ }^{4}$ Geriatrics Service. Central Hospital of the Red-Cross. Alfonso X el Sabio University. Madrid. \\ ${ }^{5}$ Emergency Service. San Carlos University Clinical Hospital. Complutense University. Madrid. \\ ${ }^{6}$ Emeritus, Pediatrtics and ACES Service. Gregorio Marañón General University Hospital, Complutense University. Madrid. \\ ${ }^{7}$ Intensive Medicine Service. Torrejón University Hospital. Francisco de Vitoria University. Madrid. \\ ${ }^{8}$ Geriatrics Service. San Carlos University Clinical Hospital. Complutense University. Madrid. \\ ${ }^{9}$ Cardiology Service. Gregorio Marañón General University Hospital, European University. Madrid. \\ ${ }^{10}$ Family Medicine. Infectious diseases. Madrid. \\ ${ }^{11}$ Infectious Diseases Service. Ramón y Cajal Hospital. University of Alcalá de Henares. Madrid. \\ ${ }^{12}$ Department of Public Health. Autonomous University. Madrid. \\ ${ }^{13}$ Internal Medicine Service. Ruber International Hospital. Madrid. \\ ${ }^{14}$ Microbiology Service. Ramón y Cajal Hospital and Ramón y Cajal Institute for Health Research (IRYCIS). Spanish \\ Network for Research in Infectious Pathology (REIPI). Madrid. \\ ${ }^{15}$ Clinical Emeritus, Community of Madrid. Clinical Microbiology and Infectious Diseases Service of the Gregorio \\ Marañón General University Hospital, Complutense University. CIBERES. Cyber of Respiratory Diseases. Madrid.
}

Article history

Received: 16 September 2021; Accepted: 9 October 2021; Published: 21 October 2021

\section{ABSTRACT}

The access to COVID vaccines by millions of human beings and their high level of protection against the disease, both in its mild and severe forms, together with a plausible decrease in the transmission of the infection from vaccinated patients, has prompted a series of questions from the members of the College of Physicians of Madrid (ICOMEM) and the society. The ICOMEM Scientific Committee on this subject has tried to answer these questions after discussion and consensus among its members. The main answers can be summarized as follows:

The occurrence of new SARS-CoV-2 infections in both vaccinated and previously infected patients is very low, in the observation time we already have. When breakthrough infections do occur, they are usually asymptomatic or mild and, purportedly, should have a lower capacity for transmission to other persons.

Vaccinated subjects who have contact with a SARSCoV-2 infected patient can avoid quarantine as long as they are asymptomatic, although this decision depends on variables such as age, occupation, circulating variants, degree of contact and time since vaccination. In countries with a high proportion of the population vaccinated, it is already suggested that fully vaccinated persons could avoid the use of masks and social distancing in most circumstances.

\section{Correspondence:}

Emilio Bouza Servicio de Microbiologia Clinica y Enfermedades Infecciosas del Hospital General Universitario Gregorio Marañón, Universidad Complutense. CIBERES. Ciber de Enfermedades Respiratorias. Madrid

E-mail:emilio.bouza@gmail.com

All authors belong to the Scientific Committee on COVID-19 of the Madrid College of Physicians (ICOMEM).
Systematic use of diagnostic tests to assess the immune response or the degree of protection against reinfection after natural infection or vaccination is discouraged, since their practical consequences are not known at this time. The existing information precludes any precision regarding a possible need for future revaccination.

This Committee considers that when mass vaccination of health care workers and the general population is achieved, SARS-CoV-2 screening tests could be avoided at least in outpatient care and in the case of exploratory procedures that do not require hospitalization.

Keywords: COVID-19, viral variants, SARS-CoV2, vaccine escape, gap COVID-19, use of masks, COVID-19 screening, vaccines, follow-up of immunized persons.

\section{Acciones y actitudes ante el paciente inmunizado contra el SARS-CoV-2}

\section{RESUMEN}

El acceso a las vacunas frente a COVID-19 de millones de seres humanos y su alto nivel de protección frente a la enfermedad, tanto en sus formas leves como graves, junto a una verosímil disminución de la transmisión de la infección desde pacientes vacunados, ha motivado una serie de preguntas de los colegiados y de la sociedad. El Comité Científico del ICOMEM sobre esta materia ha tratado de responder a dichas preguntas tras discusión y consenso entre sus miembros. Las respuestas principales pueden resumirse así: 
La aparición de nuevas infecciones por SARS-CoV-2 tanto en vacunados como en previamente infectados, es muy escasa, en el tiempo de observación del que ya disponemos. Cuando ocurren infecciones de brecha, suelen ser asintomáticas o paucisintomáticas $y$, en principio, tendrían una menor capacidad de trasmisión a otras personas.

Los sujetos vacunados que tienen contacto con un paciente infectado por SARS-CoV-2 pueden evitar la cuarentena, mientras se encuentren asintomáticos, si bien esta decisión depende de la edad, la profesión, las variantes circulantes, el grado de contacto y el tiempo pasado desde la vacunación. En paises con una alta proporción de la población vacunada se sugiere ya la posibilidad de que las personas plenamente vacunadas prescindan del uso de las mascarillas y el distanciamiento social en la mayoria de las circunstancias.

Se desaconseja la utilización de pruebas diagnósticas de manera sistemática para evaluar la respuesta inmune o el grado de protección frente a la reinfección tras la infección natural o la vacunación, dado que en este momento se ignoran sus consecuencias prácticas. La información existente hasta este momento, impide hacer cualquier precisión frente a una posible necesidad de revacunación futura.

Este Comité considera que cuando se alcance una vacunación masiva de los trabajadores sanitarios, y de la población general, podrian evitarse las pruebas de cribado de SARS-CoV-2 al menos en la actividad asistencial ambulatoria y ante procesos exploratorios que no requieren hospitalización.

Palabras clave: COVID-19, variantes virales, SARS-CoV2, escape vacunal, COVID-19 de brecha, uso de mascarillas, despistaje de COVID, vacunas, seguimiento de inmunizados

\section{INTRODUCTION}

The worldwide massive vaccination against SARS-CoV-2 infection is a milestone of historical dimension that is being made possible by the development of efficient vaccines in record time. The process, carried out in an order that prioritizes older people or those at high risk, is raising, however, some questions arising from the coexistence of two populations in our society [1-6]. On the one hand, that of vaccinated patients with a low degree of risk of contracting the disease immediately and, on the other hand, that of the population awaiting vaccination and in whom the known risks of contracting COVID-19 persist.

At the present time, it is a matter of scientific discussion, but also of political discussion, whether different attitudes should be taken with both populations, both in their medical follow-up and in the use of certain freedom of movements and social behavior. Vaccinated people do not have the same risks of contracting the disease as unvaccinated people and it is doubtful whether they require the same health monitoring and control measures.

For those reasons, the Scientific Committee of the Illustrious College of Physicians of Madrid (ICOMEM), has set out to answer some questions raised by its members using scientific evidence, where it exists, but also the experience and opinion of its partners.

\section{HOW LONG DOES PROTECTION LAST AGAINST A NEW OR RECURRENT EPISODE OF COVID-19 IN VACCINATED PATIENTS, INFECTED PATIENTS, OR BOTH?}

The duration of protection in immunized patients is a key question that has substantial implications. Laboratory studies show great heterogeneity in the magnitude of the immune response to SARS-CoV-2, with no individual factors described that can explain them well [7-9]. About 95\% of patients, or vaccinated persons, produce antibodies as early as 2 weeks after the onset of infection or after vaccination $[10,11]$.

In vitro studies show that neutralizing activity is maintained at least 6 months after infection [7] although its magnitude may be decreasing [12]. The decline in antibody titers among those who have been infected depends mainly on the intensity of the initial clinical presentation, being lower in cases where the infection has been milder [13].

In any case, memory B-cell-mediated immunity specific for spicule, RBD and nucleocapsid proteins persists after infection and will lead to a more robust antibody-mediated response in the event of a new contact with SARS-CoV-2 $[7,12]$. Memory B cells increase progressively after infection, stabilizing by the 4th or 5th month [14] and have been observed to persist for at least 6 months after infection $[7,12]$. Occasionally, the cells had not only increased in number but had undergone affinity maturation and expressed neutralizing antibodies of higher potency [12]. The T-cell response, responsible for pathogen recognition and elimination, appears 8-14 days after infection and CD8+ and CD4+ levels specific for protein $\mathrm{S}$ are maintained at $50 \%$ and $89 \%$, respectively, at 6 months $[7,15,16]$. Other studies demonstrate the persistence of this response nine months after infection [17] and one year after vaccination [18]. It is not well known whether the different vaccines differ in effectiveness and duration of the immune response and whether this is different from that produced by natural disease [19], although it would be expected that the behavior would be similar, at least in relation to the spike protein, to that produced as a consequence of naturally generated immunity.

\section{WHAT IS THE SITUATION ONE YEAR LATER FOR PATIENTS WITH COVID-19 DIAGNOSED IN THE FIRST WAVE?}

During the first months of the pandemic, the exceptionality of reinfections was assumed [20], but large series are now available analyzing the incidence and characteristics of reinfections. In a Danish study [21], PCR was performed on 525,239 subjects during the first wave, of whom 11,068 were positive. The population was subsequently evaluated 6 to 9 months later, and a reinfection rate of $0.65 \%$ was found among previously PCR-positive subjects, whereas in previously uninfected subjects the rate was $3.27 \%$, with the infection estimated to provide $80 \%$ protection against reinfection. In a population-based study conducted in the United States, 
$3,257,478$ persons were included, including 378,606 with positive serology and 2,876,773 with negative serology. After 90 days, infection rates were much lower in the serology-positive population than in those initially serology-negative, with a ratio of 0.10 (Cl $0.05-0.19$ ). Only $0.3 \%$ of seropositive patients had a positive PCR at follow-up, compared to $3 \%$ of the initially seronegative population [22]. Finally, in a study of 12,541 healthcare workers [23], 11,276 of whom had no evidence of previous infection and 1,177 were positive, there were only 3 cases of reinfection in those previously infected compared to 218 in the group of workers who were basically seronegative for SARS-CoV-2. Nine months after the start of the study, the estimated incidence of reinfection for 10,000 days of exposure was 0.07 in the basally positive patients, compared to 1.08 in the initially seronegative patients, giving a relative risk of 0.11 (0.03-0.44).

Using genomic typing, reinfection was very rare in a cohort studied in Marseille in which 6,771 cases diagnosed with COVID-19 by PCR during the first wave were followed up [24]. In 9 months of follow-up, reinfection was demonstrated in 46 of them $(0.51 \%)$ which were due to the local dominant variant.

In relation to possible risk factors, it seems that cases of reinfection are more frequent when the previous infection has been mild, when exposure is important and in the presence of immunosuppression, but in reality the cases are so few that it is difficult to draw firm conclusions. The same is true with regard to clinical features and severity.

The problem of reinfections must be followed over time, since it is to be expected that these will increase as a consequence of the decline of the immune response and also because of the impact that new variants may have, although this also needs to be confirmed.

\section{WHAT HAS BEEN THE IMPACT OF VACCINATION IN COUNTRIES THAT HAVE EXCEEDED 70\% VACCINATION COVERAGE?}

There is still little data on the impact of vaccination in countries with high vaccination rates. The most recent dynamic data highlight that the countries with the highest percentage of population vaccinated with a single dose are Malta (71.1\%), Israel (63.0\%), England (57.8\%), Canada (55.5\%) or Chile (54\%) and with complete vaccination are Israel (59.3\%), Malta (45.3\%), Chile (41.3\%), the United States (38.8\%) and the United Arab Emirates 38.8\%[25]. Some of these countries have published data on the impact of vaccination on the rate of SARS-CoV-2 infection as well as other disease outcomes.

A simulated study using demographic data from the United States evaluates the impact of a COVID-19 vaccination campaign with two doses of vaccine. Vaccination would reduce the attack rate from 9\% to 4.6\% (95\% Crl: 4.3\% - 5.0\%) over 300 days. The highest relative reduction would be among those over 65 years of age. In addition, vaccination would reduce the rate of hospitalization, ICU admission, and deaths by $63.5 \%, 65.6 \%$, and $69.3 \%$, respectively, over the same period. The authors conclude that vaccination can have a substantial impact on mitigating COVID-19 outbreaks, even with limited protection against infection [26].

The SIREN study [27] is a prospective cohort study analyzing the impact of vaccination against SARS-CoV-2 in healthcare professionals in public hospitals in the United Kingdom. After achieving a vaccination coverage of 89\% (94\% immunized with the BNT162b2b2 mRNA vaccine), the authors found an infection incidence rate of 8/10,000 person-days 21 days after the first dose and 4/10,000 person-days 7 days after the second dose, compared to $14 / 10,000$ person-days in the unvaccinated group. With this, vaccine effectiveness against all infections (symptomatic and asymptomatic) is estimated at $70 \%(95 \% \mathrm{Cl} 55-85)$ at 21 days after the first dose and up to $85 \%$ (95\% Cl 74-96) at 7 days after the second dose [27].

On December 20, 2020, Israel launched its national vaccination campaign, against COVID-19, with BNT162b2 vaccine [28]. It was implemented in the entire population selected by the Israeli Ministry of Health and, within two months, $48 \%$ of the population over 16 years of age had received full vaccination, $68.7 \%$ had at least one dose and $8 \%$ were unvaccinated patients. The vaccination campaign was initiated prioritizing the over-60s and the at-risk population. Two doses of BNT162b2 vaccine were highly effective in all age groups in preventing symptomatic and asymptomatic SARS-CoV-2 infections, COVID-19-related hospitalizations, severe illness and death, including those caused by SARS-CoV-2 variant B.1.1.7.

\section{ARE THERE DIFFERENCES IN THE DURATION OF PROTECTION BETWEEN VACCINES?}

To date, there are no studies available that directly compare the protection and duration of protection against COVID-19 between the different vaccines. In the clinical trials published to date, the comparator has always been placebo, although in the future trials this may no longer be the case.

The mRNA-1273 8 vaccine (Moderna, Inc) is the only vaccine that has published data on the duration of immunity. In a study of 33 healthy adults participating in a phase I study, the activity of protein $\mathrm{S}$ receptor binding domain (RDB) binding antibodies and neutralizing antibodies remained elevated 180 days after the second application of $100 \mu \mathrm{g}$ of vaccine (day 209) [29].

There are no published data on the duration of BNT162b2 vaccine (Pfizer/BioNTech). However, the company has issued a press release announcing the interim results of the phase 3 extension of the clinical trial. Among the 927 confirmed symptomatic cases of COVID-19 observed in the Phase 3 study, the vaccine was $91.3 \%$ effective against COVID-19 and 100\% effective against severe infection as defined by the CDC and 95.3\% as defined by the FDA. Measurements were performed between seven days and six months after the second dose [30]. These results are pending scientific peer review and possible future publication.

Ad26.COV2. S vaccine (Janssen Vaccines \& Prevention B.V.I Johnson \& Johnson) offers an efficacy from 28 days after administration of approximately $66 \%$ in preventing moderate 
to severe/critical forms of COVID-19, and $85 \%$ in preventing severe and critical forms [31]. The study showed that efficacy continued to increase for 8 weeks after administration, especially for severe and critical COVID-19. No decrease in efficacy was observed among 3,000 vaccinees followed for 11 weeks or among 1,000 vaccinees followed for 15 weeks [31].

There are no studies evaluating the duration of protection of the ChAd0x1 nCoV-19 vaccine (Oxford Vaccine Group/ AstraZeneca). The vaccine shows an overall efficacy to protect against symptomatic disease of 63.1\% (51.8-71.7) and 100\% efficacy to prevent severe cases, starting 2 weeks after the 2 nd dose [32].

\section{WHAT IS THE RISK OF TRANSMISSION OF SARS-COV-2 TO NAÏVE PERSONS FROM VACCINATED PATIENTS WHO ACOUIRE ASYMPTOMATIC OR OLIGOSYMPTOMATIC INFECTION?}

There is some indirect evidence that in infections in vaccinated persons there may be a reduced risk of SARS-CoV-2 virus transmission. First, the viral load of the relatively few vaccinated persons who become infected is generally lower than that of unvaccinated infectees [33]; this suggests lower infectivity, either because any transmission requires sufficient inoculum or because presumably the duration of the transmission period is shorter. Second, vaccination has been shown to reduce the risk of infection, both symptomatic and asymptomatic [34]. In principle, the uninfected should not be able to infect.

In Scotland, COVID-19 cases and hospitalizations in (unvaccinated) household members of vaccinated healthcare workers have been identified from December 8, 2020, to March 3 , 2021. Within 14 days of the first dose of the healthcare worker vaccine, a 30\% reduction in COVID-19 cases (27\% in hospitalizations) was observed in household contacts, consistent with an effect of vaccination on transmission [35].

In another study, in England, the proportion of household contacts who had a positive PCR between 2 and 14 days after the index cases had been vaccinated was analyzed and compared with infections in households in which the index case was not vaccinated. Adults infected with SARS-CoV-2 three weeks after receiving a dose of Pfizer-BioNTech or Oxford-AstraZeneca vaccine were $38-49 \%$ less likely to transmit the virus to their household contacts than unvaccinated index cases. The results were similar regardless of the age of the cases or contacts $[36,37]$.

It is noteworthy that the reduction in transmission in the few infected subjects after vaccination is probably greater than that observed in these two studies, as these were done after a first dose of vaccine, and the reduction in transmission is expected to be even greater after the second dose. On the other hand, the evidence has been obtained in the scenario of highest possible transmission, since both the index cases and their contacts shared a home, where people do not usually wear masks and the physical distance is very small.

This type of evidence (significant reduction in the risk of infection and transmission by vaccinees) has contributed in the
United States of America to the lifting of the obligation for vaccinees to wear masks, especially outdoors, and to maintain physical distance, both outdoors and in most enclosed spaces [38,39].

\section{IS CONFINEMENT OF VACCINATED OR PREVIOUSLY INFECTED PATIENTS JUSTIFIED AFTER CONTACT WITH A PATIENT WITH ACUTE SARS-CoV-2 INFECTION?}

The risk of infection in a fully vaccinated person or a person who has had COVID-19 and who has contact with a person with active SARS-CoV-2 infection is low. Depending on the vaccine used and the characteristics of the population, it ranges from $5 \%$ to $28 \%$ (the reinfection rate may be even lower). This has allowed some agencies to relax the measures to be taken after documented contact $[39,40]$. In the opinion of this Committee and with the information currently available, it is considered that factors that may modify the risk of infection and the severity for the individual and his or her potential contacts whom he or she might infect should be considered in making the decision to isolate and quarantine in this situation. Factors to be considered in establishing the indication for isolation and quarantine include:

- Place of residence or work: for residents or workers in healthcare or social-healthcare facilities, isolation and quarantine should still be considered if there has been well-documented close contact with a person with active SARS-CoV-2 infection.

- Immunosuppression status: immunosuppressed persons may have had a worse response to the vaccine and are at increased risk of infection.

- Age: the risk of not producing an adequate immune response is higher at older ages.

- Circulating variants: these may be variants against which protective immunity is potentially not induced by the vaccines used.

- Vaccine type: vaccines offer different degrees of protection and may protect differently against some circulating variants.

- Degree of contact: the risk of infection varies with the duration and intimacy of the contact (cohabitant in the same household, occasional outdoor contact,...).

- Time since vaccination: the duration of protection is unknown. The longer the time since vaccination, the higher the risk of infection due to the disappearance of immunity.

Thus, vaccinated persons who have had close contact with a patient with active COVID do not have to undergo quarantine or isolation, except in the circumstances previously mentioned or if they present symptoms compatible with SARS-CoV-2 infection. In the latter case, isolation and diagnostic testing for COVID-19 should be performed.

\section{IS THERE A REASON TO PROHIBIT SOCIAL AND WORK MEETINGS BETWEEN VACCINATED OR PREVIOUSLY INFECTED PEOPLE?}

In the United States of America, 101 million people have 
been vaccinated as of April 30,2021, and CDC is aware of 10,262 SARS-CoV-2 gap infections in fully vaccinated persons $(0.01 \%)$. Twenty-seven percent of those gap infections were asymptomatic and only 1.5\% of the total infected died [41].

On this basis, the CDC has just released its recommendations for vaccinated patients [39] which include the recommendation that these individuals resume their activities without wearing masks or physically distancing themselves, except when required by applicable regulations. They also recommend resuming domestic travel and refraining from pre- or post-travel testing or self-quarantine after travel. We believe that in Spain, once similar conditions to those in the United States in terms of vaccination and transmission have been achieved, these recommendations can be taken on board, although the sensible application of these measures requires the responsibility of all [42].

For the time being, fully vaccinated individuals should continue to be tested for COVID-19 if they experience compatible symptoms and follow existing travel health requirements and recommendations.

Mathematical simulations suggest that vaccination of at least 75\% of the population is necessary for the vaccine to be the only pandemic control measure (making all others unnecessary) $[43,44]$.

\section{WHAT IS THE APPROPRIATE POLICY FOR FOLLOW- UP WITH LABORATORY TESTING OF VACCINATED OR PREVIOUSLY INFECTED PATIENTS?}

Although some studies show a high correlation between IgG production and neutralizing activity [45] against the virus, current serological diagnostic tests against SARS-CoV-2 have limitations in estimating such activity $[10,11,46,47]$. In addition, the level of neutralizing antibodies that protect against COVID-19 infection or reinfection is unknown $[11,47]$. On the other hand, the presence of antibodies can decline significantly over time without necessarily leading to loss of neutralizing activity $[47,48]$ and several studies have shown that B and T cell memory, remain for a period of at least 8 to 10 months after natural or vaccinal infection $[7,11,29,48,49]$.

In summary, the duration of protective immunity and immune memory after COVID-19 infection and the ability of diagnostic tests to predict it are unknown [10]. Therefore, the use of such tests to assess the immune response after vaccination or the degree of protection against reinfection after the first infection is generally discouraged $[50,51]$. At present, a low antibody titer is not a recommendation to administer additional doses of the same or other vaccines or to decide between one or two doses in vaccines where two doses are recommended [51].

\section{WHAT IS EXPECTED FROM CELLULAR IMMUNITY TESTING IN PATIENTS IMMUNIZED AGAINST SARS-CoV-2?}

Cell-mediated immunity appears to be an important part of the immune response to SARS-CoV-2 whether naturally occurring or vaccine-induced. In natural infection, effective virus clearance appears to require collaboration between humoral and cellular responses [52]. CD8+ T-cell depletion in convalescent macaques partially abrogates the protective efficacy of natural immunity against re-exposure to SARS-CoV-2, suggesting a role for cellular immunity in the context of declining or subprotective antibody titers and indicating that cellular immune responses may contribute to protection if antibody responses are suboptimal [53].

Cell-mediated immunity by itself does not prevent infection, but it is important in clearing it once it has begun. They can make the difference between a mild infection and a severe one requiring hospital treatment. If the cellular response is able to eliminate infected cells before the virus spreads through the body, it will influence the course of the disease. It could also reduce transmission by restricting the amount of circulating virus, which would mean that it would spread fewer viral particles in the community.

Multiple studies suggest that circulating antibodies to coronaviruses may be short-lived or of low magnitude and potency $[54,55]$. Therefore, rapid expansion of vaccine-induced memory lymphocytes may be needed to stimulate immunity and reduce disease and COVID-19 transmission [56,57].

For these reasons, one of the main goals of vaccines against SARS-CoV-2 should be to induce memory $T$ cells both in the circulation and in tissues. Initial studies with the different vaccines already marketed demonstrated the induction of a sufficient cellular response. It is now important to monitor the stability of memory T cells over months and years in animal models and in humans. Work in SARS suggests that memory T cells against SARS-CoV-2 are long-lived, but more research and more time are required for full evaluation of the duration of immunity to SARS-CoV-2 [58]. Unfortunately, at this time, we do not yet have simple tests for routine clinical application to measure the cell-mediated immune response in patients immunized against COVID [59].

\section{WHAT WOULD BE THE REASONS AND TIMING OF NEW BOOSTER DOSES?}

We have just commented that the time of protection due to both natural immunity and vaccination or the association of the two is not precisely known. Nor do we have any routine test that would help us to mark the beginning of a state of unprotection and risk of reinfection. Taking as an example a long-term epidemiological study (35 years) on immunity to other seasonal coronaviruses and evaluating the frequency of reinfection by sampling every 3 to 6 months, it was concluded that protective immunity is short-lived and natural reinfections occurred more frequently after 12 months [60]. We do not know if this case of one type of coronavirus represents all others and in particular SARS-CoV-2.

The aspects discussed above would open up the possibility that the administration of booster doses of existing vaccines or the administration of new vaccines adapted to the new variants that might appear might be necessary, but at this time both possibilities, in our opinion, remain speculative. Very re- 
cent data would allow us to be even more optimistic about the persistence of the immunity provided by natural infection or current vaccines [61].

\section{IN VACCINATED PATIENTS OR PATIENTS WITH PAST INFECTION WHO ARE GOING TO UNDERGO SURGERY OR INVASIVE TESTS, ARE COVID SCREENING TESTS NECESSARY PRIOR TO SURGERY OR INVASIVE TESTS?}

The hospital environment has nothing to do with other scenarios of everyday life, and therefore it is necessary to adapt protection measures to the environment in which we move. In general, hospitals must remain safe places, since patients are a more vulnerable population in themselves. It is essential to keep the "clean" areas separate from the "contaminated" areas (COVID-19 inpatient wards) in order to be able to provide good and safe care. To achieve this, hospitals have implemented a series of measures that have made it possible to reduce the risk of nosocomial infection to a minimum. These measures include screening with PCR tests for patients who are going to undergo surgery, invasive tests that generate aerosols (endoscopy, spirometry, etc.) or require hospital admission. In addition to giving them specific recommendations on limiting contacts, use of masks, etc.

The appearance of vaccines that reduce the risk of severe disease and hospitalization $[33,62,63]$ and the publications that point out that vaccinated persons can contract the infection but usually have a very low viral load [33], is countered by the fact that this risk is not zero.

We believe that at this time, in the hospital setting, it is necessary to continue to maintain the recommendations and screening with PCR (currently the most specific and sensitive test) for the group of patients who are going to undergo surgery, hospitalization, etc., in order to avoid possible in-hospital outbreaks. It is important to take into account, when maintaining this measure, the percentage of the population vaccinated.

Another different scenario is hospital outpatient care of vaccinated patients. As previously mentioned, before the patient undergoes any diagnostic-therapeutic test that generates aerosols, minor surgery or major outpatient surgery, he/ she is screened with PCR. In this case the risk of transmission, professional-patient or vice versa, is even lower, since both groups are usually vaccinated. Moreover, these procedures are performed in areas where there is no contact with hospitalized patients. It is in this context that this committee is of the opinion that PCR could be omitted prior to the performance of these outpatient procedures, maintaining only the standard prevention measures.

\section{WHAT SHOULD BE THE ATTITUDE TOWARDS VACCINATED PATIENTS IN WHOSE EVOLUTION THE ABSENCE OF ANTIBODIES IS DETECTED?}

As previously discussed, the use of antibody titer measurement tests to assess the immune response after vaccination or the degree of protection against reinfection after the first infection is discouraged $[50,51]$. Protection against COVID-19 by vaccination is not $100 \%$, which means that with current vaccines there is a variable percentage of COVID-19 gap. This situation is common in almost all vaccine-preventable diseases. In these patients, it does not seem plausible or indicated to perform a new vaccination with a different model (RNA-attenuated virus and vice versa), or to administer booster doses of vaccine, as mentioned above.

True protection in these situations will be provided by the environment when the degree of vaccination reaches at least $75 \%$ of the population. Therefore, in these patients in whom the risk of gap COVID-19 is higher [64], it would be advisable to maximize the usual preventive measures.

\section{CONCLUSIONS}

1.- As a consequence of the activation of the immune response in patients vaccinated or infected with SARSCoV-2, the occurrence of reinfections in the observation period available to date (6 to 15 months) is very low. This is demonstrated by data from countries with already very high rates of vaccinated population.

2.- Gap infections in patients with previous infection, vaccinated, or both, are generally asymptomatic or paucisymptomatic and potentially have a lower capacity of transmission to non-immunized persons, as a consequence of presenting a lower inoculum.

3.- There are no comparative studies between vaccines that can demonstrate differences in the duration of protection between them.

4.- The use of serological tests indiscriminately for the follow-up of patients after natural infection or vaccination is discouraged, since their clinical significance and practical consequences are not known at this time.

5.- Data from countries with a high proportion of the population vaccinated suggest the possibility that fully vaccinated persons can be dispensed with the use of masks and social distancing in most circumstances. They can also avoid quarantine after contact with infected patients with exceptions, determined by type of work, advanced age or immunosuppression, among others.

6.- The need for revaccination with the same or new vaccines is, at this time, merely speculative, since the existing information prevents any precision on this subject.

7.- PCR screening of patients to be hospitalized should be maintained for the time being in order to avoid nosocomial outbreaks, until community transmission rates in our environment fall further. On the other hand, this Committee considers that screening tests could be avoided in outpatient activity where the contact of the vaccinated patient is restricted to health personnel, who are also vaccinated. 


\section{FUNDING}

None to declare

\section{CONFLICTS OF INTEREST}

The authors declare no conflicts of interest

\section{REFERENCES}

1- Golob JL, Lugogo N, Lauring AS, Lok AS. SARS-CoV-2 vaccines: a triumph of science and collaboration. JCl Insight. 2021;6(9). DOI: 10.1172/jci.insight.149187

2. Galdiero $M$, Galdiero $M$, Folliero $V$, Zannella $C$, De Filippis $A$, Mali $A$, et al. SARS-CoV-2 vaccine development: where are we? Eur Rev Med Pharmacol Sci. 2021;25(6):2752-84. DOI: 10.26355/eurrev_202103_25439

3. Kwok HF. Review of Covid-19 vaccine clinical trials - A puzzle with missing pieces. Int J Biol Sci. 2021;17(6):1461-8. DOI: 10.7150/ ijbs.59170

4. He Q, Mao Q, Zhang J, Bian L, Gao F, Wang J, et al. COVID-19 Vaccines: Current Understanding on Immunogenicity, Safety, and Further Considerations. Front Immunol. 2021;12:669339. DOI: 10.3389/fimmu.2021.669339

5. Novelli $G$, Biancolella $M$, Mehrian-Shai $R$, Colona VL, Brito AF, Grubaugh ND, et al. COVID-19 one year into the pandemic: from genetics and genomics to therapy, vaccination, and policy. Hum Genomics. 2021;15(1):27. DOI: 10.1186/s40246-021-00326-3

6. Koch T, Fathi A, Addo MM. The COVID-19 Vaccine Landscape. Adv Exp Med Biol. 2021;1318:549-73. DOl: 10.1007/978-3-030-637613_31

7. Dan JM, Mateus J, Kato $Y$, Hastie KM, Yu ED, Faliti CE, et al. Immunological memory to SARS-CoV-2 assessed for up to 8 months after infection. Science. 2021;371(6529). DOI: 10.1126/science. abf4063

8. Li Z, Liu J, Deng $H$, Yang $X$, Wang $H$, Feng $X$, et al. SARS-CoV-2-specific $T$ cell memory is long-lasting in the majority of 2 convalescent COVID-19 individuals. bioRxiv. 2021;10.1101/2020.11.15.383463.

9. Sattler A, Angermair S, Stockmann H, Heim KM, Khadzhynov $D$, Treskatsch $\mathrm{S}$, et al. SARS-CoV-2 specific T-cell responses and correlations with COVID-19 patient predisposition. J Clin Invest. 2020;130(12):6477-89. DOI: 10.1172/jci140965

10. Chvatal-Medina M, Mendez-Cortina Y, Patiño PJ, Velilla PA, Rugeles MT. Antibody Responses in COVID-19: A Review. Front Immunol. 2021;12:633184. DOI: 10.3389/fimmu.2021.633184

11. Ong DSY, Fragkou PC, Schweitzer VA, Chemaly RF, Moschopoulos CD, Skevaki C. How to interpret and use COVID-19 serology and immunology tests. Clin Microbiol Infect. 2021. DOI: 10.1016/j. cmi.2021.05.001

12. Gaebler C, Wang Z, Lorenzi JCC, Muecksch F, Finkin S, Tokuyama $M_{1}$ et al. Evolution of antibody immunity to SARS-CoV-2. Nature. 2021;591(7851):639-44. DOI: 10.1038/s41586-021-03207-w
13. Seow J, Graham C, Merrick B, Acors S, Pickering S, Steel KJA, et al. Longitudinal observation and decline of neutralizing antibody responses in the three months following SARS-CoV-2 infection in humans. Nat Microbiol. 2020;5(12):1598-607. DOI: 10.1038/ s41564-020-00813-8

14. van Kampen JJA, van de Vijver D, Fraaij PLA, Haagmans BL, Lamers MM, Okba N, et al. Duration and key determinants of infectious virus shedding in hospitalized patients with coronavirus disease-2019 (COVID-19). Nat Commun. 2021;12(1):267. DOI: 10.1038/s41467-020-20568-4

15. Snyder TM, Gittelman RM, Klinger M, May DH, Osborne EJ, Taniguchi $R$, et al. Magnitude and Dynamics of the T-Cell Response to SARS-CoV-2 Infection at Both Individual and Population Levels. medRxiv. 2020. DOI: 10.1101/2020.07.31.20165647

16. Zuo J, Dowell AC, Pearce $H_{1}$ Verma K, Long HM, Begum J, et al. Robust SARS-CoV-2-specific T cell immunity is maintained at 6 months following primary infection. Nat Immunol. 2021;22(5):6206. DOI: 10.1038/s41590-021-00902-8

17. Amor S, Fernández Blanco L, Baker D. Innate immunity during SARS-CoV-2: evasion strategies and activation trigger hypoxia and vascular damage. Clin Exp Immunol. 2020;202(2):193-209. DOI: 10.1111/cei.13523

18. Folegatti PM, Bittaye M, Flaxman A, Lopez FR, Bellamy D, Kupke $A$, et al. Safety and immunogenicity of a candidate Middle East respiratory syndrome coronavirus viral-vectored vaccine: a dose-escalation, open-label, non-randomised, uncontrolled, phase 1 trial. Lancet Infect Dis. 2020;20(7):816-26. D0I: 10.1016/s14733099(20)30160-2

19. Widge AT, Rouphael NG, Jackson LA, Anderson EJ, Roberts PC, Makhene $M_{1}$ et al. Durability of Responses after SARS-CoV-2 mRNA1273 Vaccination. N Engl J Med. 2021;384(1):80-2. DOI: 10.1056/ NEJMc2032195

20. Tomassini S, Kotecha D, Bird PW, Folwell A, Biju S, Tang JW. Setting the criteria for SARS-CoV-2 reinfection - six possible cases. J Infect. 2021;82(2):282-327. DOI: 10.1016/j.jinf.2020.08.011

21. Hansen $\mathrm{CH}$, Michlmayr D, Gubbels SM, Mølbak K, Ethelberg S. Assessment of protection against reinfection with SARS-CoV-2 among 4 million PCR-tested individuals in Denmark in 2020: a population-level observational study. Lancet. 2021;397(10280):120412. DOI: $10.1016 / \mathrm{s} 0140-6736(21) 00575-4$

22. Harvey RA, Rassen JA, Kabelac CA, Turenne W, Leonard S, Klesh R, et al. Association of SARS-CoV-2 Seropositive Antibody Test With Risk of Future Infection. JAMA Intern Med. 2021. DOI: 10.1001/jamainternmed.2021.0366

23. Lumley SF, O'Donnell $D$, Stoesser NE, Matthews PC, Howarth $A$, Hatch SB, et al. Antibody Status and Incidence of SARS-CoV-2 Infection in Health Care Workers. N Engl J Med. 2021;384(6):533-40. DOI: 10.1056/NEJMoa2034545

24. Brouqui $P$, Colson $P$, Melenotte $C$, Houhamdi L, Bedotto M, Devaux C, et al. COVID-19 re-infection. Eur J Clin Invest. 2021;51(5):e13537. DOI: 10.1111/eci.13537

25. World in data. COVID-19 World Vaccination Progress. Daily and Total Vaccination for COVID-19 in the World from Our World in Data. 
https://wwwkagglecom/gpreda/covid-world-vaccination-progress. 2021. DOI:

26. Moghadas SM, Vilches TN, Zhang K, Wells CR, Shoukat A, Singer $\mathrm{BH}$, et al. The impact of vaccination on COVID-19 outbreaks in the United States. Clin Infect Dis. 2021. DOI: 10.1093/cid/ciab079

27. Hall VJ, Foulkes $S$, Saei $A$, Andrews N, Oguti B, Charlett $A$, et al. COVID-19 vaccine coverage in health-care workers in England and effectiveness of BNT162b2 mRNA vaccine against infection (SIREN): a prospective, multicentre, cohort study. Lancet. 2021. DOI: 10.1016/s0140-6736(21)00790-x

28. Rossman H, Shilo S, Meir T, Gorfine M, Shalit U, Segal E. COVID-19 dynamics after a national immunization program in Israel. Nat Med. 2021. DOI: 10.1038/s41591-021-01337-2

29. Doria-Rose $N$, Suthar MS, Makowski M, O'Connell S, McDermott $A B$, Flach $B$, et al. Antibody Persistence through 6 Months after the Second Dose of mRNA-1273 Vaccine for Covid-19. N Engl J Med. 2021. DOI: 10.1056/NEJMc2103916

30. Nota de prensa. Pfizer/BioNTech confirm high efficacy and no serious safety concerns through up to six months following second dose in updated topline analysis of landmark COVID-19 vaccine study [Internet]. [Revisado 01 Apr 2021; consultado 17 may 2021]. . Disponible en: https://wwwpfizercom/news/press-release/ press-release-detail/pfizer-and-biontech-confirm-high-efficacy-and-no-serious. 2021.

31. Sadoff J, Gray G, Vandebosch A, Group. eaES. Safety and Efficacy of Single-Dose Ad26.COV2.S Vaccine against Covid-19. . N Engl J Med 2021 Apr 21 Online ahead of print. 2021. DOI: 10.1056/NEJMoa2101544.

32. Voysey M, Costa Clemens SA, Madhi SA, Weckx LY, Folegatti PM, Aley $P K_{1}$ et al. Single-dose administration and the influence of the timing of the booster dose on immunogenicity and efficacy of ChAdOx1 $n C o V-19$ (AZD1222) vaccine: a pooled analysis of four randomised trials. Lancet. 2021. DOI: 10.1016/s0140-6736(21)00432-3

33. Levine-Tiefenbrun $M_{1}$ Yelin I, Katz R, Herzel E, Golan Z, Schreiber $L_{\text {, }}$ et al. Initial report of decreased SARS-CoV-2 viral load after inoculation with the BNT162b2 vaccine. Nat Med. 2021;27(5):790-2. DOI: 10.1038/s41591-021-01316-7

34. Jones NK, Rivett $L$, Seaman $S$, Samworth RJ, Warne B, Workman $C_{\text {, }}$ et al. Single-dose BNT162b2 vaccine protects against asymptomatic SARS-CoV-2 infection. Elife. 2021;10. DOI: 10.7554/eLife.68808

35. Shah ASV, Wood R, Gribben C, Caldwell D, Bishop J, Weir A, et al. Risk of hospital admission with coronavirus disease 2019 in healthcare workers and their households: nationwide linkage cohort study. Bmj. 2020;371:m3582. DOI: 10.1136/bmj.m3582

36. Harris RJ, Hall JA, Zaidi A, Andrews NJ, Dunbar JK, Dabrera G. Effect of Vaccination on Household Transmission of SARS-CoV-2 in England. N Engl J Med. 2021;385(8):759-760. doi: 10.1056/NEJMc2107717.

37. Mahase E. Covid-19: One dose of vaccine cuts risk of passing on infection by as much as 50\%, research shows. Bmj. 2021;373:n1112. DOI: 10.1136/bmj.n1112

38. Christie A, Mbaeyi SA, Walensky RP. CDC Interim Recommendations for Fully Vaccinated People: An Important First Step. Jama.

\section{1;325(15):1501-2. DOI: 10.1001/jama.2021.4367}

39. Centers for Disease Control and Prevention. Interim Public Health Recommendations for Fully Vaccinated People. . Disponible en: https://wwwcdcgov/coronavirus/2019-ncov/vaccines/fully-vaccinated-guidancehtml. 2021.

40. European Centre For Disease P. Interim guidance on the benefits of full vaccination against COVID-19 for transmission and implications for non-pharmaceutical interventions. Disponible en: https:// wwwecdceuropaeu/en/publications-data/interim-guidance-benefits-full-vaccination-against-covid-19-transmission. 2021.

41. COVID-19 Vaccine Breakthrough Infections Reported to CDC United States, January 1-April 30, 2021. MMWR Morb Mortal Wkly Rep. 2021;70(21):792-3. DOI: 10.15585/mmwr.mm7021e3

42. Organización Mundial de la Salud. Enfermedad por el coronavirus (COVID-19): Vacunas. 28 de octubre de 2020. Accesible en https:// www.who.int/es/news-room/q-a-detail/coronavirus-disease-(covid-19)-vaccines.

43. Bartsch SM, O'Shea KJ, Ferguson MC, Bottazzi ME, Wedlock PT, Strych U, et al. Vaccine Efficacy Needed for a COVID-19 Coronavirus Vaccine to Prevent or Stop an Epidemic as the Sole Intervention. Am J Prev Med. 2020;59(4):493-503. DOI: 10.1016/j.amepre.2020.06.011

44. Shen M, Zu J, Fairley CK, Pagán JA, An L, Du Z, et al. Projected COVID-19 epidemic in the United States in the context of the effectiveness of a potential vaccine and implications for social distancing and face mask use. Vaccine. 2021;39(16):2295-302. D0I: 10.1016/j. vaccine.2021.02.056

45. Noval MG, Kaczmarek ME, Koide A, Rodriguez-Rodriguez BA, Louie $\mathrm{P}$, Tada $\mathrm{T}$, et al. Antibody isotype diversity against SARS-CoV-2 is associated with differential serum neutralization capacities. Sci Rep. 2021;11(1):5538. DOI: 10.1038/s41598-021-84913-3

46. Wang Z, Schmidt F, Weisblum Y, Muecksch F, Barnes CO, Finkin S, et al. mRNA vaccine-elicited antibodies to SARS-CoV-2 and circulating variants. Nature. 2021;592(7855):616-22. DOI: 10.1038/ s41586-021-03324-6

47. García F, Melón $S$, Navarro D, Paño JR, JC. G. Recomendaciones Institucionales Covid-19. Organización del diagnóstico de SARSCoV-2 y estrategias de optimización. SEIMC; 2020. [Revisado 14 Oct 2020; consultado 17 may 2021]. Disponible en: https:// seimcorg/contenidos/documentoscientificos/recomendaciones/ seimc-rc-2020-COVID19-OrganizacionDiagnosticopdf. 2021.

48. Vanshylla K, Di Cristanziano V, Kleipass F, Dewald F, Schommers $P$, Gieselmann $L$, et al. Kinetics and correlates of the neutralizing antibody response to SARS-CoV-2 infection in humans. Cell Host Microbe. 2021. DOI: 10.1016/j.chom.2021.04.015

49. Sonnleitner ST, Prelog M, Jansen B, Rodgarkia-Dara C, Gietl S, Schönegger $\mathrm{CM}$, et al. Maintenance of neutralizing antibodies over ten months in convalescent SARS-CoV-2 afflicted patients. Transbound Emerg Dis. 2021. DOI: 10.1111/tbed.14130

50. Grupo de Trabajo Técnico de Vacunación COVID-19 dIPdPyRdV, CISNS. Estrategia de vacunación frente a COVID19 en España. Actualización 7. 11 mayo de 2021. [Consultado 17 may 2021]. . Disponible en: https://wwwmscbsgobes/profesionales/saludPublica/ 
prevPromocion/vacunaciones/covid19/docs/COVID-19_Actualizacion7_EstrategiaVacunacionpdf. 2021.

51. (CDC). CfDCaP. Interim Clinical Considerations for Use of COVID-19 Vaccines Currently Authorized in the United States [Internet]. Reviewed. National Center for Immunization and Respiratory Diseases. [Revisado 14 May 2021; consultado 17 may 2021]. Disponible en: https://wwwcdcgov/vaccines/covid-19/info-by-product/clinical-considerationshtml\#. 2021.

52. Ni L, Ye F, Cheng ML, Feng $Y$, Deng $Y Q$, Zhao $H$, et al. Detection of SARS-CoV-2-Specific Humoral and Cellular Immunity in COVID-19 Convalescent Individuals. Immunity. 2020;52(6):971-7.e3. DOI: 10.1016/j.immuni.2020.04.023

53. McMahan K, Yu J, Mercado NB, Loos C, Tostanoski LH, Chandrashekar $\mathrm{A}$, et al. Correlates of protection against SARS-CoV-2 in rhesus macaques. Nature. 2021;590(7847):630-4. DOI: 10.1038/s41586020-03041-6

54. Long QX, Tang XJ, Shi QL, Li Q, Deng HJ, Yuan J, et al. Clinical and immunological assessment of asymptomatic SARS-CoV-2 infections. Nat Med. 2020. DOI: 10.1038/s41591-020-0965-6

55. Robbiani DF, Gaebler C, Muecksch F, Lorenzi JCC, Wang Z, Cho A, et al. Convergent antibody responses to SARS-CoV-2 in convalescent individuals. Nature. 2020;584(7821):437-42. DOI: 10.1038/s41586020-2456-9

56. DiPiazza AT, Graham BS, Ruckwardt TJ. T cell immunity to SARS-CoV-2 following natural infection and vaccination. Biochem Biophys Res Commun. 2021;538:211-7. DOI: 10.1016/j. bbrc.2020.10.060

57. Mazzoni A, Maggi L, Capone M, Spinicci M, Salvati L, Colao MG, et al. Cell-mediated and humoral adaptive immune responses to SARS-CoV-2 are lower in asymptomatic than symptomatic COVID-19 patients. Eur J Immunol. 2020;50(12):2013-24. DOI: 10.1002/ eji.202048915

58. Jarjour NN, Masopust D, Jameson SC. T Cell Memory: Understanding COVID-19. Immunity. 2021;54(1):14-8. DOI: 10.1016/j.immuni.2020.12.009

59. Guihot A, Litvinova E, Autran B, Debré P, Vieillard V. Cell-Mediated Immune Responses to COVID-19 Infection. Front Immunol. 2020;11:1662. DOI: 10.3389/fimmu.2020.01662

60. Edridge AWD, Kaczorowska J, Hoste ACR, Bakker M, Klein M, Loens $\mathrm{K}_{1}$ et al. Seasonal coronavirus protective immunity is short-lasting. Nat Med. 2020;26(11):1691-3. DOI: 10.1038/s41591-020-1083-1

61. Tada T, Dcosta BM, Samanovic MI, Herati RS, Cornelius A, Zhou H, et al. Convalescent-Phase Sera and Vaccine-Elicited Antibodies Largely Maintain Neutralizing Titer against Global SARS-CoV-2 Variant Spikes. mBio. 2021:e0069621. D0I: 10.1128/mBio.00696-21

62. Thompson MG, Burgess JL, Naleway AL, Tyner HL, Yoon SK, Meece $J$, et al. Interim Estimates of Vaccine Effectiveness of BNT162b2 and mRNA-1273 COVID-19 Vaccines in Preventing SARS-CoV-2 Infection Among Health Care Personnel, First Responders, and Other Essential and Frontline Workers - Eight U.S. Locations, December 2020-March 2021. MMWR Morb Mortal Wkly Rep. 2021;70(13):495-500. DOI: 10.15585/mmwr.mm7013e3

63. Amit $\mathrm{S}$, Regev-Yochay $\mathrm{G}$, Afek $\mathrm{A}$, Kreiss Y, Leshem E. Early rate reduc- tions of SARS-CoV-2 infection and COVID-19 in BNT162b2 vaccine recipients. Lancet. 2021. DOI: 10.1016/s0140-6736(21)00448-7

64. Menéndez Colino R, Merello de Miguel A, Argentina F, Barcons Marqués $M$, Chaparro Jiménez $B$, López Hernández $P$, et al. [Evolution of COVID-19 at nursing homes from the second wave to vaccination. Description of a coordination program between Primary Care, Geriatrics and Public Health.]. Rev Esp Salud Publica. 2021;95. 
Rafael Cantón ${ }^{1,2}$

José Barberán ${ }^{3}$

Manuel Linares ${ }^{4}$

José María Molero ${ }^{5}$

José Miguel Rodríguez-

González-Moro ${ }^{6}$

Miguel Salavert ${ }^{7}$

Juan González del Castillo8

\section{Decalogue for the selection of oral antibiotics for lower respiratory tract infections}

\begin{abstract}
${ }^{1}$ Servicio de Microbiología. Hospital Universitario Ramón y Cajal and Instituto Ramón y Cajal de Investigación Sanitaria (IRYCIS). Madrid. Spain.

${ }^{2}$ CIBER de Enfermedades Infecciosas. Instituto de Salud Carlos III. Madrid. Spain.

${ }^{3}$ Servicio de Medicina Interna y Enfermedades infecciosas, Hospital Universitario HM Monteprincipe, Universidad San Pablo CEU. Madrid, Spain.

${ }^{4}$ Servicio de Microbiologia Clínica, Hospital Universitario Príncipe de Asturias, Madrid, Spain.

${ }^{5}$ Centro de Salud San Andrés. Medicina de Familia, Servicio Madrileño de Salud, Madrid, Spain.

${ }^{6}$ Servicio de Neumología. Hospital Universitario Príncipe de Asturias, Alcalá de Henares, Spain

${ }^{7}$ Unidad de Enfermedades Infecciosas. Área Clínica Médica, Servicio de Medicina Interna, Hospital Universitario y Politécnico La Fe and Instituto de Investigación Sanitaria La Fe (IIS La Fe), Valencia, Spain.

${ }^{8}$ Servicio de Urgencias, Hospital Clínico San Carlos and Instituto de Investigación Sanitaria San Carlos (IdISSC), Madrid, Spain
\end{abstract}

Article history

Received: 30 December 2021; Accepted:12 January 2022; Published: xx January 2022

\begin{abstract}
Lower respiratory tract infections, including chronic obstructive pulmonary disease exacerbations (COPD-E) and community acquired pneumonia (CAP), are one of the most frequent reasons for consultation in primary care and hospital emergency departments, and are the cause of a high prescription of antimicrobial agents. The selection of the most appropriate oral antibiotic treatment is based on different aspects and includes to first consider a bacterial aetiology and not a viral infection, to know the bacterial pathogen that most frequently cause these infections and the frequency of their local antimicrobial resistance. Treatment should also be prescribed quickly and antibiotics should be selected among those with a quicker mode of action, achieving the greatest effect in the shortest time and with the fewest adverse effects (toxicity, interactions, resistance and/or ecological impact). Whenever possible, antimicrobials should be rotated and diversified and switched to the oral route as soon as possible. With these premises, the oral treatment guidelines for mild or moderate COPD-E and CAP in Spain include as first options betalactam antibiotics (amoxicillin and amoxicillin-clavulanate and cefditoren), in certain situations associated with a macrolide, and relegating fluoroquinolones as an alternative, except in cases where the presence of Pseudomonas aeruginosa is suspected.
\end{abstract}

Keywords: respiratory tract infections; bacterial infections; oral treatment; antibiotic use; antimicrobial resistance

Correspondence:

Rafael Cantón.

Servicio de Microbiologia. Hospital Universitario Ramón y Cajal and Instituto Ramón y Cajal de Investigación Sanitaria (IRYCIS). Madrid. Spain.

E-mail: rafael.canton@salud.madrid.org

Juan Gonzalez del Castillo.

Servicio de Urgencias, Hospital Clínico San Carlos and Instituto de Investigación Sanitaria San Carlos (IdISSC), Madrid, Spain.

E-mail: jgonzalezcast@gmail.com

\section{Decálogo para la selección del antibiótico oral en las infecciones respiratorias de vías bajas}

\section{RESUMEN}

Las infecciones del tracto respiratorio inferior, incluyendo las exacerbaciones de la enfermedad pulmonar obstructiva crónica (EPOC) y la neumonía adquirida en la comunidad (NAC), son uno de los motivos de consulta más frecuentes en atención primaria y los servicios de urgencias hospitalarios, y son la causa de una elevada prescripción de antimicrobianos. La selección del tratamiento oral más adecuado con antibióticos se basa en diferentes aspectos e incluye considerar en primer lugar una etiología bacteriana y no una infección vírica, conocer los patógenos bacterianos que más frecuentemente causa estas infecciones y la frecuencia local de su resistencia antimicrobiana. Además, el tratamiento debe prescribirse rápidamente y los antibióticos deben seleccionarse entre los que tienen un modo de acción más rápido, logrando el mayor efecto en el menor tiempo y con el menor número de efectos adversos (toxicidad, interacciones, resistencia y/o impacto ecológico). Siempre que sea posible, hay que rotar y diversificar los antimicrobianos y pasar a la vía oral lo antes posible. Con estas premisas, las guias de tratamiento oral de la exacerbación leve o moderada de la EPOC y NAC en España incluyen como primera opción los antibióticos betalactámicos (amoxicilina y amoxicilina-clavulánico y cefditoreno), en determinadas situaciones asociados a un macrólido, y relegando las fluoroquinolonas como alternativa, salvo en los casos en que se sospeche la presencia de Pseudomonas aeruginosa.

Palabras clave: infecciones del tracto respiratorio; infecciones bacterianas: tratamiento oral; uso de antimicrobianos; resistencia antimicrobiana, 


\section{INTRODUCTION}

Lower respiratory tract infections (LRTI) are one of the most frequent reasons for consultation in primary care and hospital emergency departments, and are the cause of a high prescription of antimicrobial agents [1-3]. It is therefore necessary to consider a series of premises that guide their choice, especially in cases in which the patient's situation allows oral treatment, since their follow-up will be performed on an outpatient basis. For this reason, a group of professionals from the fields of primary care, hospital emergency medicine, internal medicine, infectious diseases, pneumology and clinical microbiology have proposed a Decalogue that summarises the criteria that, as a priority, should be taken into account when choosing oral antimicrobial treatment in exacerbations of chronic obstructive pulmonary disease (COPD) and community-acquired pneumonia (CAP). Many of the aspects listed here have been previously reviewed in greater depth [4-8]. This Decalogue is based on published scientific evidence and the personal experience of the panel of the authors. The recommendations are aligned with the principles of the National Plan against Antimicrobial Resistance (PRAN) of the Spanish Agency of Medicines and Health Products (AEMPS), which aims, among other objectives, to improve the prescription of this group of drugs in order to reduce antimicrobial resistance (https://www.resistenciaantibioticos.es/es, accessed 30 December 2021).

\section{1.- IS THIS A BACTERIAL INFECTION?}

The most common cause of COPD exacerbation is bacterial infection of the tracheobronchial tree. However, there are other possible aetiologies such as virus, contamination, thromboembolism or heart failure and the cause is not known in a third of cases. Identifying the aetiology that causes this exacerbation is of great importance in order to establish appropriate treatment. It is also important to identify patients who can be safely treated without antibiotics and to optimise treatment for those who need it [9]. In CAP, the majority is of bacterial aetiology, although in almost two thirds of patients it may remain unidentified, either because of a lack of microbiological diagnosis or because insufficient methods are used to identify the pathogen [10].

To identify a bacterial aetiology as the cause of the exacerbation, markers such as C-reactive protein and procalcitonin have been described, but the systematic usefulness of their use in these cases has not been established and their use in real life is very restricted [9]. A meta-analysis suggests that procalcitonin may be useful in reducing antibiotic prescribing, without affecting the rate of treatment failure, length of hospitalisation, recurrence or mortality [11]. However, due to the methodological limitations, the evidence is still low to moderate, so a general recommendation for the use of this or any other biomarker to establish the bacterial aetiology of an exacerbation cannot be established. A similar situation occurs in patients with CAP, where procalcitonin may be more useful in those cases where serial determinations are performed and as a guide in reducing the duration of antimicrobial therapy $[12,13]$.

The classic Anthonisen criteria [14] for COPD exacerbation, based on clinical data of changes in symptomatology, increased dyspnoea, cough and sputum, and especially change in sputum colour, with all possible concerns, are still present in daily practice. The administration of antibiotics in COPD is more effective than placebo in exacerbations that meet at least two of the following three criteria: increased dyspnoea, sputum purulence or increased sputum volume. However, of

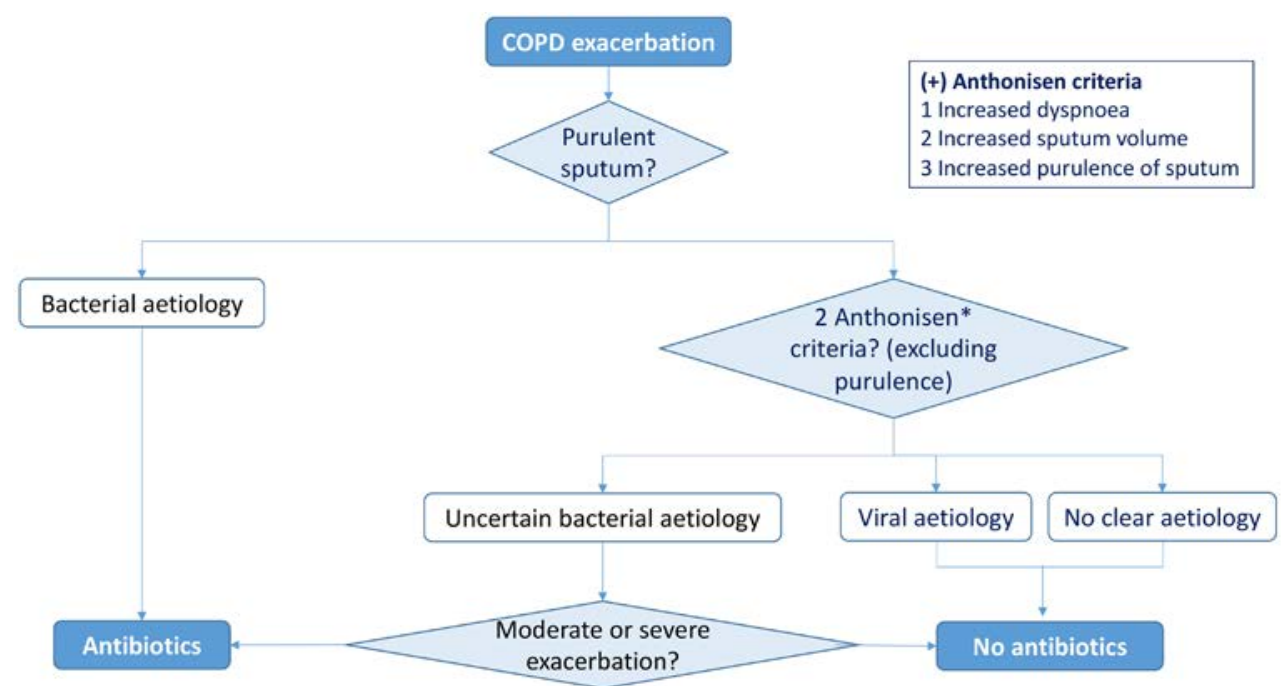

Figure 1 Suspicion of bacterial infection in COPD exacerbation and decision of antimicrobial treatment [modified from reference 9] 

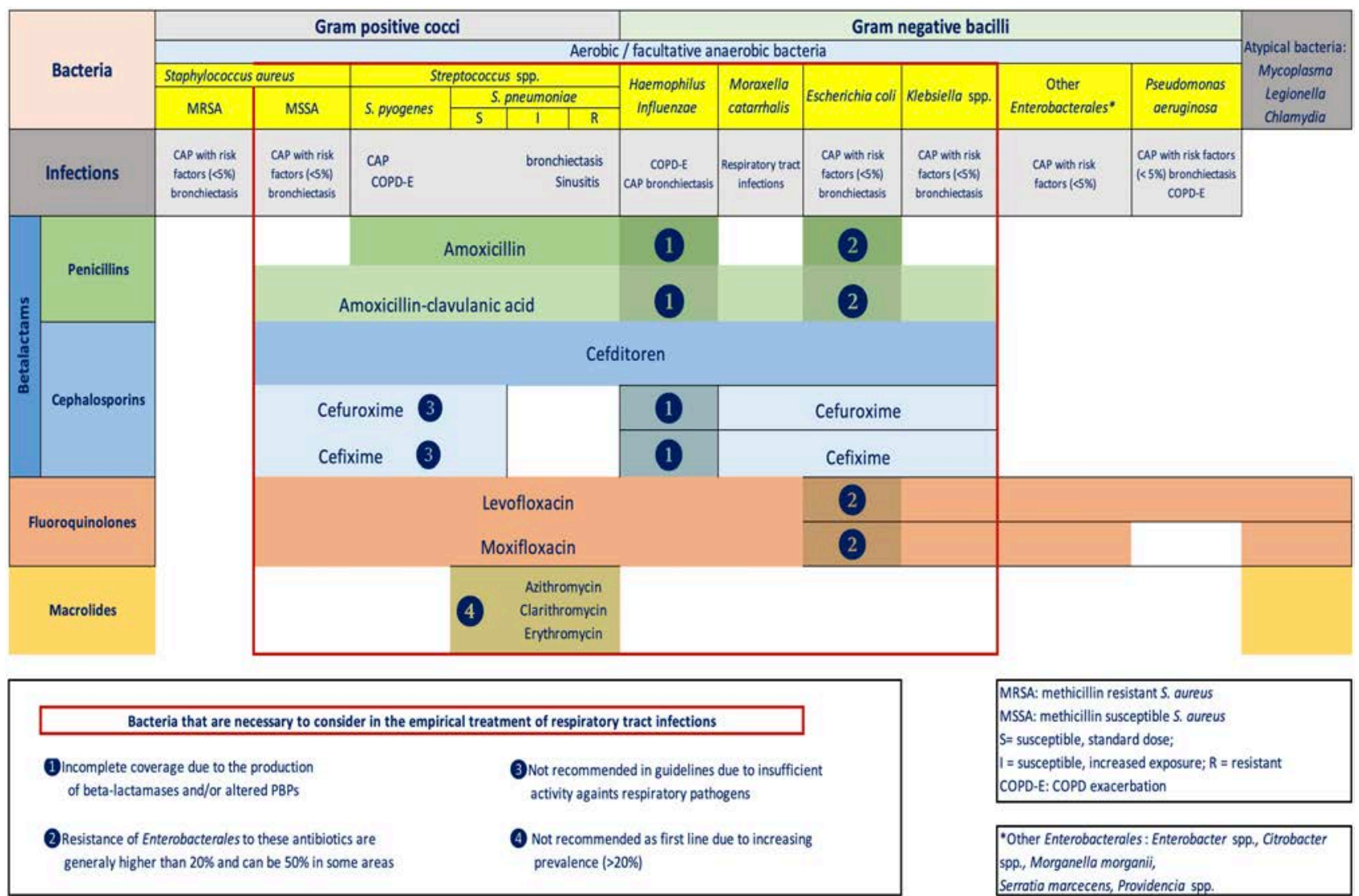

MRSA: methicillin resistant $S$. aureus MSSA: methicillin susceptible $S$. oureus $S=$ susceptible, standard dose; I = susceptible, increased exposure; $R=$ resistant COPD-E: COPD exacerbation

esistance of Enterobacterales to these antibiotics are prevalence $(>20 \%)$

"Other Enterobacterales: Enterobacter spp., Citrobacter spp., Morganella morganii, Serratio marcecens, Providencia spo.

Figure 2 Antimicrobial spectrum of the main oral antibiotics in the treatment of lower respiratory tract infections [modified from reference 4].

the three recommended criteria, the one that best predicts bacterial infection is the change in sputum colour and purulence $[14,15]$ (Figure 1). In contrast, mucous sputum is rarely associated with bacterial infection [17] and in these cases other causes must be considered. Antibiotics are particularly indicated in severe COPD exacerbations and in the presence of purulent sputum. Sputum analysis (Gram stain and culture) is only indicated in patients with severe or very severe exacerbations, in those with frequent exacerbations, bronchiectasis, need for ventilation or in case of antibiotic treatment failure.

In CAP the diagnostic criteria are based on radiological changes and respiratory symptoms such as cough, purulent sputum, dyspnoea and chest pain, as well as fever. In patients with criteria for hospitalisation, Gram stain and culture are recommended as a minimum when sputum is purulent and detection of Streptococcus pneumoniae and Legionella pneumophila antigen [18].

\section{2.- MOST LIKELY AETIOLOGY: MAXIMISING ERADICATION AND ADJUSTING SPECTRUM}

Microbiological diagnosis in COPD exacerbations and CAP is difficult to establish, even when complex and invasive diagnostic methods are used. Although the possible role of the usual microbiota in LRTIs, especially in COPD exacerbation, is currently being discussed, the focus is on the microorganisms traditionally associated with these infections. In CAP, the aetiology is usually monomicrobial. Globally, the most frequent agent is $S$. pneumoniae (20-65\%) [19] and should always be taken into account when establishing antibiotic coverage. With increasing age, the frequency of microorganisms classically referred to as "atypical" (L. pneumophila, Mycoplasma pneumoniae and Chlamydia pneumoniae) decreases and the incidence of Haemophilus influenzae and Gram-negative bacilli increases $[10,20,21]$. In a smaller percentage of the cases, it may be due to viral agents (12-18\%) and there may be associations of several pathogens (8-14\%) [19]. However, the aetiology of CAP is conditioned by comorbidity, baseline functional status, severity of the acute episode, previously received antimicrobial treatments, contact with the hospital system or place of residence. Therefore, an aetiological approach according to risk factors for resistant microorganisms and severity level is also recommended [22].

In COPD exacerbations, the microorganisms involved vary 


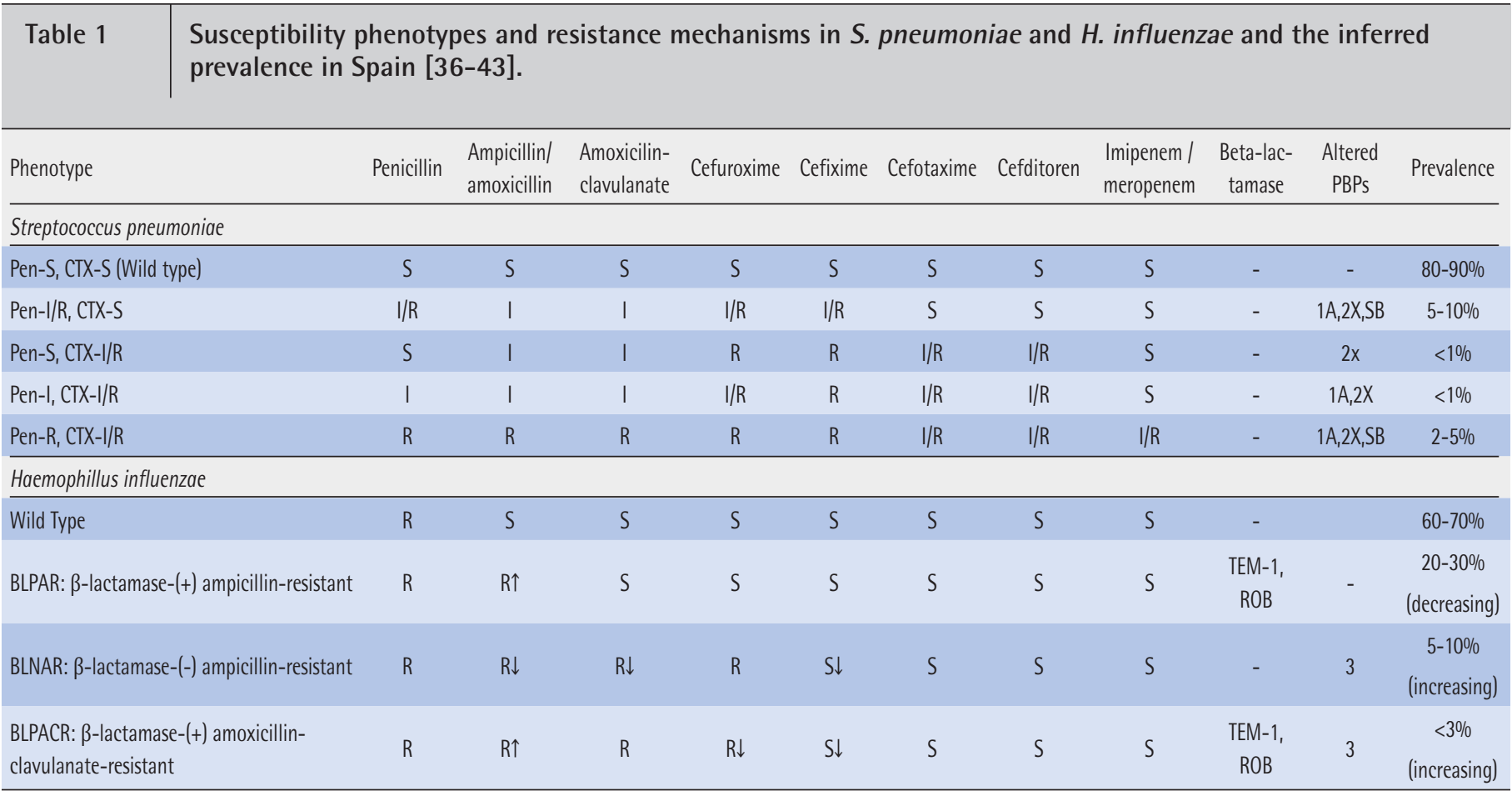

Arrows indicate low ( $\mathrm{R} \downarrow)$ and high level $(\mathrm{R} \uparrow$ ) resistance or decrease susceptibility $(\mathrm{S} \downarrow)$.

according to the type of patient, risk factors and comorbidities. In many cases, they have been named "potentially pathogenic microorganisms" (PPMs) as they can be isolated both in the stable phase and during exacerbations $[23,24]$. H. influenzae is more prominent than in CAP, although $S$. pneumoniae and $M$. catarrhalis may also be present, and to a lesser extent, the socalled "atypicals" [25]. In older patients, Pseudomonas aeruginosa, other Gram-negative bacilli or even Staphylococcus aureus may also be isolated in microbiological cultures, especially in those with bronchiectasis [26]. Anaerobic microorganisms may be detected in COPD, especially in the stable phase. These tend to disappear or become less diverse during exacerbations and have therefore been assigned a protective value against PPM infection [27].

On the other hand, in the antibiotic treatment of CAP, we must try to achieve microbiological eradication, for which it is most convenient to use the most active antibiotics with the highest bactericidal activity against the possible causative pathogens and those that best meet the PK/PD parameters of clinical and microbiological efficacy. In COPD exacerbation, although the therapeutic objective should also be eradication, in practice reduction in the bacterial load is achieved, and a correlation can be established between this reduction and the appearance of a new exacerbation [28]. However, effectiveness, with the aim of achieving maximum microbiological eradication, must be achieved by using the antibiotic with the most restricted spectrum possible to the microorganisms most commonly isolated in this type of infection, in such a way as to minimise antibiotic selection pressure or alterations in the patient's microbiota. Currently, cefditoren, levofloxacin, moxifloxacin and amoxicillin-clavulanic acid in this order have the most appropriate spectrum over the most prevalent pathogens involved in COPD exacerbations and CAP. Moreover, they have also the most relevant PK/PD characteristics in these infections and are therefore included in most antimicrobial treatment guidelines [2,9,16,20,29-35] (Figure 2).

\section{3.- KNOWING THE LOCAL RESISTANCE MAP}

In addition to knowing the possible microorganisms involved in LRTI, it is always necessary to take into account the resistance mechanisms that may be present and to know their frequency at the local level. This will ensure better criteria in the choice of antimicrobial treatment. The latest report of the Instituto de Salud Carlos III, the reference center in Spain, which collects data on resistance of different pathogens, indicates that resistance rates to penicillin and third generation cephalosporins in $S$. pneumoniae have decreased over the years, reaching 21.7\% and 6.0\%, respectively, in 2020 [36]. Resistance to macrolides would be close to $25 \%$, with simultaneous resistance to both compounds estimated at around $12 \%$. These isolates are increasing in some serotypes not included in the thirteen-valent pneumococcal conjugate vaccine $[37,38]$. Surveillance studies conducted in Spain have shown that among oral cephalosporins, cefditoren has a similar behaviour to intravenous third-generation cephalosporins, with higher rates of resistance to cefaclor, cefuroxime and cefixime [39]. Resistance to fluoroquinolones is reported to be less than $2 \%$ [36]. 
Although there are few recent data in Spanish studies, resistance in $\mathrm{H}$. influenzae due to production of beta-lactamases and conferring resistance to amoxicillin, but with sensitivity to amoxicillin-clavulanic acid, has stabilised at around 20-25\%. On the other hand, and as in other countries, resistance to amoxicillin and oral cephalosporins such as cefaclor or cefuroxime, and sometimes to amoxicillin-clavulanic acid, is increasing $[40,41]$. Third-generation cephalosporins, cefotaxime or ceftriaxone, would not be affected, as would cefditoren, which maintains its activity in these isolates [38]. Beta-lactamase-producing strains with altered PBPs and combined resistance to amoxicillin, amoxicillin-clavulanic acid, oral cephalosporins and, to a lesser extent, third-generation cephalosporins, including cefditoren, are also increasing. As in S. pneumoniae, resistance to fluoroquinolones would be scarce and would be present mainly in patients with chronic bronchial infection and extensive exposure to this group of antimicrobials [41-43].

Recent data on $M$. catarrhalis are also scarce, although they indicate a high proportion of isolates with beta-lactamases (TEM or BRO) inhibited by clavulanic acid and low percentages of resistance to macrolides and fluoroquinolones $[44,45]$.

M. pneumoniae is intrinsically resistant to penicillins, with macrolide resistance below 10\%. In contrast, susceptibility to tetracyclines and fluoroquinolones is almost universal in this pathogen [46].

Finally, $P$. aeruginosa is intrinsically resistant to a large number of antimicrobials, narrowing oral therapeutic options to fluoroquinolones. Resistance figures may vary depending on the type of patient, being higher in those with chronic bronchial infection with previous treatment with this group of antimicrobials. In Spain, it would be higher than that found in other countries [47].

Table 1 shows the common susceptibility phenotypes in S. pneumoniae and $H$. influenzae, the associated resistance mechanism and the inferred prevalence of these phenotypes in Spain [36-43].

\section{4.- TO BE QUICK IN ACTION AND EFFECT}

In general, in most infectious syndromes and particularly in LRTI, the efficacy of antimicrobial treatment is fundament in two pillar: 1) control of the microbial inoculum (guided by the antimicrobial chosen) and 2) control of the focus (instrumental or surgical, organic or inorganic biofilm, ...). Derived from both actions, the speed of medical action in the execution of each control strategy and that of the antimicrobial activity translated into its bactericidal effect are essential elements. In fact, infection is an increasingly dynamic process and must be managed as a time-dependent code. In short, "time is money, and time is life".

To achieve these objectives in LRTIs, we must demand that the antimicrobial chosen has two important characteristics: 1) adequate antimicrobial spectrum and 2) optimal antimicrobial potency. Through its ability to cover the microbiological spectrum in an exacerbation of COPD or CAP, we will be sure to have antimicrobial activity against the main aetiological causes of these infectious syndromes, also taking into account the resistance characteristic of these microorganisms (point 3 of the Decalogue). Regarding the antimicrobial potency, we should select those antibiotics with a high activity translated into the ability to eliminate a greater number of microorganisms per unit of time, i.e. to achieve greater inhibition and, if possible, eradication of bacterial inoculum in the shortest possible time.

A bactericidal antibiotic is defined as an antibiotic with the ability to reduce $\geq 3 \log _{10}(99.9 \%) / \mathrm{cfu} / \mathrm{mL}$ of the bacterial inoculum in a given period of time [48]. Examples of this group of antibiotics include beta-lactams, aminoglycosides and fluoroquinolones. Their bactericidal activity is generally determined by so-called lethality or kill curves, which measure the reduction of the bacterial inoculum over time. In general, a bacterial inoculum of $10^{6} \mathrm{cfu} / \mathrm{mL}$ is assumed and the effect is measured over a period of less than 24 hours. An antibiotic is defined as bacteriostatic when the reduction in bacterial inoculum is $<3 \log _{10}$ cfu/mL over a given period of time. Examples of these other antibiotics include, among others, macrolides, clindamycin and tetracyclines. Furthermore, some antibiotics exhibit greater bactericidal activity at a higher dose or concentration of the drug at the site of infection and in a shorter period of time, i.e. the higher the dose of the antibiotic, the greater the bactericidal activity, and the faster as in the case of aminoglycosides. However, others maintain their bactericidal activity independently of the dose or concentration; this is the case of beta-lactams.

Therefore, in CAP and exacerbation of COPD and particularly in elderly patients or with comorbidities, antibiotics with faster action are more adequate $[4,20]$. This feature can improve the prognosis of the patients and avoid complications or sequels. When a comparison of the duration of the comorbidity period is made when compare treatments with antibiotics that achieve rapid decreases in bacterial concentration versus those that only produces slow decreases, the results are in favour of the formers. Antibiotics with high bactericidal capacity have a shorter comorbidity period and, therefore, an earlier and more stable period of normality, in contrast to antibiotics with low bactericidal capacity. This translates into better control of the patient's comorbidity, early clinical stabilisation, and a decrease in the average length of stay and its associated costs $[49,50]$. Late control of infection may even jeopardise patient survival as a result of decompensation of comorbidities.

The bactericidal activity of oral antibiotics used in the treatment of community-acquired LRTIs are clearly different against the main respiratory pathogens (S. pneumoniae, $\mathrm{H}$. influenzae and $M$. catarrhalis) $[5,51]$. When comparing several of them (cefuroxime, cefpodoxime, cefixime, amoxicillin-clavulanic acid, cefditoren and levofloxacin), cefditoren and levofloxacin show a greater bactericidal effect in the $\log _{10} \mathrm{cfu} / \mathrm{h}$ reduction curves, both at 4 and 24 hours.

Another relevant aspect in the context of LRTIs is speed of reduction of inflammatory parameters, clinical recovery and 
microbiological eradication [52]. In clinical studies of patients with COPD exacerbations comparing cefditoren versus levofloxacin, the clinical success rate in the overall study population was $78 \%$, with a clinical cure rate of $80 \%$ in the cefditoren group and $75 \%$ in the levofloxacin group [53]. Overall, microbiological eradication in the test of cure was obtained in $85 \%$ of the total study population, although it was slightly higher for levofloxacin compared to cefditoren without statistically significant differences; a higher number of patients with moderate gastrointestinal adverse effects in the levofloxacin-treated group was observed. In addition, inflammatory parameters (such as interleukin-6) were significantly reduced in the test of cure with both cefditoren and levofloxacin compared to the first visit. Although no significant difference, the reduction was higher with cefditoren. The study concluded that this antibiotic represents a valid option in the treatment of mild to moderately severe cases of COPD exacerbation in the outpatient setting, as its use was associated with a significant rapid reduction in interleukin-6 and other biomarkers of lung inflammation and epithelial damage [53].

The relationship between antimicrobial activity and bactericidal activity is important for all the aspects mentioned above. Moreover, it is relevant for the prevention of selection of resistant strains at the focus of infection, in what would derive from the "fall and rise" theory in the case of COPD or in the avoidance of resistance emergence among the main community respiratory pathogens causing pneumonia through the concept called "selection window" and the "mutant prevention concentration" (MPC) indicator parameter (point 6 of this Decalogue).

\section{5.- ANTIMICROBIAL TOLERANCE AND SAFETY}

The oral antibiotics most commonly used in the treatment of LRTIs can generally be considered safe drugs [8]. Their adverse effects are infrequent and mild and rarely produce irreversible situations in the patients. Knowledge of clinically relevant adverse effects allows for a more judicious use of antibiotics based on the first principle of do no harm, primun non nocere, and the positioning of those that should be included in clinical treatment guidelines as first choice. However, in recent years, concerns have arisen with some of them, in particular fluoroquinolones, due to safety alerts generated by regulatory agencies, relegating them to a secondary position despite their excellent antimicrobial profile against respiratory pathogens associated with COPD exacerbation and CAP $[54,55]$. From a strict safety point of view, it is preferable to initiate treatment with a beta-lactam antibiotic as long as its efficacy is guaranteed according to the expected microorganism. 0therwise, a macrolide or, if appropriate, a fluoroquinolone may be chosen depending on the type and location of the infection and the patient [8]. On which antibiotic to choose within each class, the prioritisation seems clear in the case of beta-lactams, cefditoren over amoxicillin-clavulanic acid, and in the case of macrolides, azithromycin over the others, but it less so in the case of fluoroquinolones.
The adverse effects of antibiotics that affect their safety are due to different mechanisms including direct toxicity, interaction with other drugs, development of resistance and alteration of the microbiota [56]. The latter two are addressed in point 7 of this Decalogue. Toxicity is generally low at approved therapeutic doses and may be due to direct or indirect action on cells or tissues. These include mitochondrial dysfunction leading to organ damage and immunoparalysis. Damage can be caused by dose-dependent pharmacodynamics and pharmacokinetic interactions between the antibiotic and the eukaryotic cells and other drugs respectively, such as cardiac arrhythmias with fluoroquinolones and macrolides and collagen toxicity and neurotoxicity with fluoroquinolones. It is also caused by idiosyncratic immune-mediated reactions similar to anaphylaxis with effects ranging from rashes to toxic epidermal necrolysis or Stevens-Johnson syndrome [57].

Nausea, vomiting and diarrhoea are the most frequent adverse effects of oral antibiotics, but are particularly observed when clavulanic acid is administered at doses above $250 \mathrm{mg} /$ day. As amoxicillin $500 \mathrm{mg}$ and $875 \mathrm{mg}$ tablets available in Spain contain more than $125 \mathrm{mg}$ of clavulanic acid, the usual three-times-daily regimens increase the risk of vomiting and diarrhoea. In addition, amoxicillin-clavulanic acid is considered a hepatotoxic drug and has been associated with genetic variations in the HLA type II system, advanced age and the use of several courses of treatment $[58,59]$. Fluoroquinolones can produce different adverse effects, already discussed above. These are more frequent in patients with specific risk factors for each adverse effect [60] (Table 2).

In relation to interactions with other drugs, they usually occur by modification of their pharmacokinetic properties at different levels that affect absorption, protein binding, metabolism, especially by impact on cytochromes (CYP), elimination or other mechanisms such as serotonergic syndrome in the case of ciprofloxacin [57]. In these cases, there may be a change in the effect of the antibiotic or concomitant drug, which must be assessed in each patient and may require a change of regimen.

\section{6.- MINIMISING TREATMENT DAYS}

The length of an antibiotic treatment plays an important role in the development of antibiotic resistance $[61,62]$. Resistance induction and selection or resistant bacterial population increase with exposure time [61]. The traditional claim that early discontinuation of antibiotic treatment promotes antibiotic resistance is not supported by evidence $[63,64]$. On the contrary, longer duration of antibiotic treatment regimens has been associated with higher rates of resistance as it produces selective pressure not only on potential pathogens but also on microorganisms that are present in the usual microbiota $[62,65]$.

There is evidence to support the safety and efficacy of short versus prolonged antibiotic treatment regimens for most common infections treated in outpatient care $[66,67]$ and in more severe infections treated at the hospital level $[68,69]$. In 


\begin{tabular}{l|l}
\hline Table 2 & $\begin{array}{l}\text { Adverse effects due to fluoroquinolones related to patients at incremental risk } \\
{[61] .}\end{array}$ \\
\hline Adverse effect & Patients at incremental risk \\
\hline OT syndrome & Treatment with non-potassium-sparing diuretics or significant baseline bradycardia \\
\hline Tendonitis & Older age, male, chronic renal disease, corticosteroid use \\
\hline Retinal detachment & Age, past history, cataract surgery \\
\hline Aortic dissection & Age, hypertension, congenital aortic valve anomalies, hereditary connective system disorders \\
\hline Dysglycemias & Advanced age, diabetes, renal insufficiency and concurrent use of hypoglycemic drugs (especially sulphonylureas) \\
\hline Psychiatric effects & Personal or family history \\
\hline
\end{tabular}

\begin{tabular}{l|cc}
\hline Table 3 & $\begin{array}{l}\text { General recommendations of length } \\
\text { period of antimicrobial treatment in } \\
\text { lower respiratory tract infections. }\end{array}$ \\
\hline Infection & Route & Administration \\
\hline Mild & Oral & 5 \\
Moderate/severe & Oral & $5-7$ \\
Severe & Intravenous + oral & 7 (2 intravenous +5 oral) \\
\hline
\end{tabular}

addition, shortening antibiotic time has other advantages such as better adherence, fewer adverse effects and lower cost [65]. Treating bacterial infections for only as long as necessary is probably the safest and most feasible means of reducing unnecessary antibiotic use [70]. The duration of antimicrobial treatment should be individualised and tailored to the clinical response of the patient [71]. Therefore, it should be withdrawn, as soon as possible, once the symptoms of infection are controlled [65]. Table 3 includes general recommendations of duration of antimicrobial treatment in LRTs.

\section{7.- SELECT THE ANTIBIOTIC WITH THE LEAST ANTIMICROBIAL RESISTANCE DEVELOPMENT AND ECOLOGICAL EFFECTS}

The use of antimicrobials should minimise the development of resistance as much as possible. This is achieved with antimicrobials with high bacterial eradication capacity and with treatment schemes that ensure effective concentrations at the focus of infection that exceed the so-called mutant prevention concentration (MPC) that prevents microorganisms from entering in the window of selection $[72,73]$. Also with those that allow to reduce at maximum level the bacterial inoculum at the focus of infection. Treatment with amoxicillin (2 $\mathrm{g} / 12 \mathrm{~h}$ ), cefditoren (400 mg/12 h) or levofloxacin (500 mg/12 h) has a lower risk of selecting for resistance in $S$. pneumoniae than with lower doses of amoxicillin (875/8 h) or levofloxacin
(500 mg/12 h) or with the macrolides or the oral cephalosporins cefuroxime (500 mg/12 h) or cefixime (400 mg/12 h) $[4,74]$ (Figure 3).

Furthermore, regardless of resistance, the antimicrobial chosen must avoid ecological damage to the normal microbiota. This occurs with antimicrobials that do not reduce the socalled "colonisation resistance", a property for which the normal microbiota persists over time on its normal niche despite external aggression or disturbance and also named resiliency. This is generally produced with antimicrobials with minimum or null effect on anaerobic microbiota which are normally those that prevent colonisation of mucosal surfaces with multidrug-resistant bacteria. Several studies have shown that cephalosporins, including those administered by oral route, or amoxicillin have less ecological impact than fluoroquinolones, clindamycin or macrolides, with the usual microbiota recovering more quickly than with the former [75-77]. Fluoroquinolones also have a greater effect on the development of Clostridioides difficile infection than penicillins or cephalosporins $[78,79]$.

\section{8.- ROTATION AND DIVERSIFICATION OF ANTIMICROBIALS}

Antibiotic rotation, understood as the suspension of the use of antimicrobial agents for a certain period of time to be reintroduced later, is not a new concept. It has been used in different clinical settings since the 1950s as one of the strategies proposed to control the emergence of antimicrobial resistance, reduce infection rates or reduce antimicrobial consumption $[80,81]$. This approach aims to reduce the exposure time of bacteria to an antibiotic and thus reduce the selective pressure it exerts on the microbiota of the individual, minimising the emergence of resistance. Several studies have shown that this method is particularly useful in certain clinical departments or patient settings where there is a high use of antimicrobials [82].

On the other hand, diversifying the use of antimicrobials has also been shown to be effective in reducing the emergence and reduction of resistance [83].

In the case of COPD treatment, both strategies are critical 


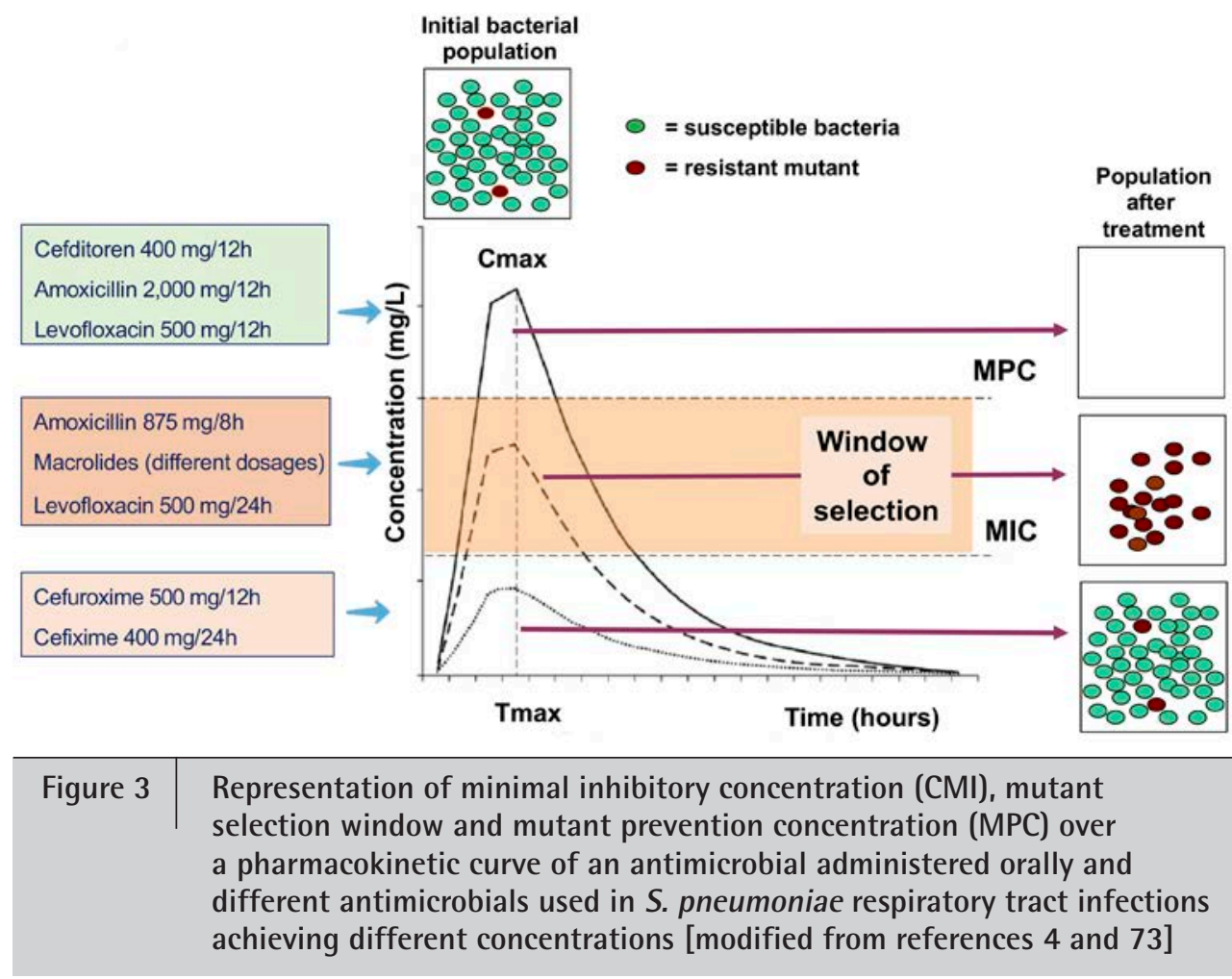

to resolve exacerbations. Antimicrobial rotation should include the antimicrobials with most eradication property, so that it effectively contributes to reduce the risk of selection of resistance by decreasing the bacterial burden (quantitative "fall and rise" theory) [6]. It is important to identify the most appropriate antibiotic groups to be rotated in our geographic area, which may vary from one area to another depending on resistance rates. The sequences to be followed in the rotations and the time that should elapse between rotations should also be defined at local level.

In CAP, diversification in antibiotic treatment avoids exerting a high selection pressure and thus spreading strains resistant to that antibiotic [6]. This requires close epidemiological surveillance in the different work settings and insistence on shortening the duration of empirical treatments according to clinical guidelines to reduce antibiotic pressure globally.

\section{9.- SWITCH TO THE ORAL ROUTE AS SOON AS POSSIBLE}

The advantages of implementing sequential therapy are the reduction of antimicrobial treatment costs, the reduced need for accessories and devices for the preparation and administration of the drug (needles, infusion sets, syringes, intravenous solutions, etc), providing the patient with greater comfort, mobility and independence, reducing complications by decreasing the frequency of adverse effects related to intravenous administration, mainly phlebitis and nosocomial infec- tion associated with this route (secondary bacteraemia, septic phlebitis), avoiding the possibility of contracting any type of nosocomial infection associated with a long hospital stay and reducing hospital stay $[84,85]$.

The criteria that patients must meet to proceed with the switch to oral formulation are: heart rate $<100 \mathrm{bpm}$, respiratory rate $<24 \mathrm{rpm}$, axillary temperature below $37.2^{\circ} \mathrm{C}$, systolic blood pressure $>90 \mathrm{mmHg}$, oxygen saturation $>90 \%$, good level of consciousness and tolerance to the oral route [86].Regarding the selection of the appropriate oral antimicrobial, this should be done in the same way as the intravenous depending on the possible expected aetiology (causative microorganism), local sensitivity and resistance patterns, PK/PD characteristics of each antibiotic and the epidemiological situations and particular characteristics of the patient (age, comorbidity, contraindications, allergic history, etc.).

Table 4 shows the equivalence of antimicrobials for establishing sequential therapy in patients with COPD exacerbations or CAP. In the case of amoxicillin-clavulanic acid and fluoroquinolones, there are galenic presentations of the same antibiotic for both routes. However, in the case of amoxicillin-clavulanic acid, it should be considered that the change from intravenous dosing to the available oral formulation (875mg/125mg) implies a decrease in the dose of amoxicillin, which would fall within the mutant selection window, and an increase in clavulanic acid, so it may also be appropriate to perform sequential therapy with another beta-lactam such as cefditoren. In the case of third generation intravenous cepha- 


\section{\begin{tabular}{l|l} 
Table 4 & Equivalence of antimicrobials for
\end{tabular} sequential therapy in patients with COPD exacerbations or CAP}

\begin{tabular}{ll}
\hline Intravenous treatment & Oral treatment \\
\hline Amoxicillin-clavulanate & Amoxicillin-clavulanate or cefditoren \\
\hline Fluoroquinolone & Fluoroquinolones \\
\hline Macrolides & Macrolides \\
Cefotaxime or ceftriaxone & Cefditoren \\
\hline
\end{tabular}

losporins, the most appropriate sequential therapy is cefditoren due to the fact that it has a similar spectrum and intrinsic activity [4].

\section{0.- KEEPING UP TO DATE: CONSULT THE ANTIMICROBIAL TREATMENT GUIDELINES}

Along with proven experience and practical common sense, knowledge based on scientific evidence is a third key element in the competence of healthcare and/or research doctors. They must try to keep up to date with scientific knowledge. The increased volume of information, together with the changing dynamism of the results of studies and trials, and their interpretations, makes difficult to manage the acquisition and assimilation of knowledge. In addition to the modern and fragile express assertions of a multitude of social networks, a more rigorous and controlled way is to consult clinical practice guidelines, consensus documents and recommendations made by methodologists and experts in each subject under the umbrella of official agencies or scientific societies.

The objectives of a clinical guideline, such as those on LRTIs, should be to improve the appropriateness of empirical antibiotic treatment, reduce uncertainty and medical errors, assist in decision-making, improve adherence to protocols, reduce and optimise the use of antimicrobials, allow for shorter treatment durations and/or stays, help control the selection of resistant bacteria and reduce costs. Other functions that an international, national or local guidelines may include are serving as a reference standard or criterion for quality and appropriateness of treatments in programmes for antimicrobial stewardship, keeping knowledge up to date by compiling new evidence on the approach to infections (diagnostic criteria, pharmacological and non-pharmacological recommendations according to patient characteristics and severity of the process. Moreover, they are tools for shared decision-making with the patient and for training activities.

The guidelines must be constantly updated, consult the appropriate sources, rigorously analyse the results of the studies selected and evaluated, and offer comparative exposition of these results with respect to the considered recommendations that will be offered in the guideline. Failure to do so may result in the opposite ending with outdated antibiotic treat- ment indications that do not include all available options, that do not establish appropriate dosages and precise duration of treatment, or that even show doubt or confusion.

In the case of guidelines for the selection of oral antibiotics in LRTIs, in addition to international guidelines, there are good and sufficient national guidelines and expert documents available in Spain [4-8,20,16,30-35,87-89]. In these ones, we have indications for antimicrobial treatment in two major respiratory infectious syndromes: exacerbation of COPD and outpatient CAP. For both entities, a classification is established from mild to severe, or risk factors for specific microorganisms that require a more special or selected antimicrobial therapy (e.g. of P. aeruginosa) or by age and underlying comorbidities. Based on this, different scenarios or risk factors are cross-referenced with the main microorganisms causing infection, priority indications for empirical antibiotic treatment are given and other alternative options are listed (Table 5) [34].

In turn, with regard to the antibiotics available and recommended for the oral treatment of LRTIs, the guidelines show which antibiotics are available, to which class or families they belong, their spectrum of microorganisms included according to their mechanism of action and intrinsic activity and, of course, comparative assessments are established in relevant aspects such as safety and tolerance, drug interactions and risk of dysbiosis due to alteration of the microbiome, all translated in a practical way, for example, into the risk of causing infection by $C$. difficile.

of the classes of antimicrobials included and assessed in these guidelines, for classical respiratory bacterial pathogens (such as S. pneumoniae, H. influenzae and M. catarrhalis), the beta-lactam family stands out especially in their indication, distancing them from the fluoroquinolone family for several reasons, one of them being the safety, tolerance and pharmacological interactions, with a better profile for the former and with pharmacological alerts indicating toxicity problems and complications with the latter.

However, not all beta-lactams have the same characteristics and behave in the same way, and some of the guidelines go so far as to comparatively dissect the different oral options in this family: aminopenicillin and beta-lactamase inhibitor combination (such as amoxicillin-clavulanic acid) or second (cefuroxime axetil) and third generation cephalosporins (cefixime and cefditoren). In turn, clear differences can be established between the cephalosporins themselves, as some of them may show a lack of sufficient or optimal intrinsic activity against Gram-positive microorganisms (pneumococci), as is the case for cefixime or ceftibuten, or offer only a deficient and suboptimal concentration achieved in the lung at the dose marketed or indicated in the summary of product characteristics (such as cefuroxime), making some of these beta-lactam options less advisable than other third-generation oral cephalosporins (cefditoren), which are more recommended for community respiratory pathology.

In addition, not all guidelines include other relevant as- 


\section{Table 5}

Oral antimicrobials recommended in mild or moderate COPD exacerbations and community acquired pneumonia [34]

\begin{tabular}{|c|c|c|c|}
\hline & \multirow[b]{2}{*}{ Microorganisms } & \multicolumn{2}{|c|}{ Empiric antibiotics* } \\
\hline & & First choice & Alternative \\
\hline \multicolumn{4}{|l|}{ COPD exacerbation (COPD-E) } \\
\hline \multirow[t]{3}{*}{ Mild } & H. influenzae & Amoxicillin-clavulanate $875-125 \mathrm{mg} / 8 \mathrm{~h} 5-7$ days & Levofloxacin ${ }^{\complement} 500 \mathrm{mg} / 24 \mathrm{~h}, 5-7$ days \\
\hline & S. pneumoniae & Cefditoren $400 \mathrm{mg} / 12 \mathrm{~h}, 5$ days & Moxifloxacin ${ }^{\mathrm{c}} 400 \mathrm{mg} / 24 \mathrm{~h}, 5-7$ days \\
\hline & M. catarrhalis & & \\
\hline \multirow{3}{*}{$\begin{array}{l}\text { Moderate without risk factors } \\
\text { for } P \text {. aeruginosa }\end{array}$} & H. influenzae & Amoxicillin-clavulanate $875-125 \mathrm{mg} / 8 \mathrm{~h} 5-7$ days & Levofloxacin ${ }^{\complement} 500 \mathrm{mg} / 24 \mathrm{~h}, 5-7$ days \\
\hline & S. pneumoniae & Cefditoren $400 \mathrm{mg} / 12 \mathrm{~h}, 5$ days & Moxifloxacin ${ }^{c} 400 \mathrm{mg} / \mathrm{d}, 5-7$ days \\
\hline & M. catarrhalis + Pen-R S. pneumoniae & & \\
\hline \multirow{2}{*}{$\begin{array}{l}\text { Moderate with risk factors } \\
\text { for } P \text {. aeruginosa }\end{array}$} & P. aeruginosa & Ciprofloxacin $750 \mathrm{mg} / 12 \mathrm{~h}, 5-7$ days & \\
\hline & & Levofloxacin $500 \mathrm{mg} / 12 \mathrm{~h}, 5-7$ days & \\
\hline \multicolumn{4}{|l|}{ Community acquired pneumonia (CAP) } \\
\hline \multirow{3}{*}{$\begin{array}{l}\text { Non severe CAP in }<65 \text { years, without } \\
\text { significant chronic morbidity or without risk } \\
\text { factors for infection with Gram-negatives } \\
\text { or Legionella spp, irrespective of aetiological } \\
\text { suspicion }\end{array}$} & S. pneumoniae & Amoxicillin $1 \mathrm{~g} / 8 \mathrm{~h}, 5-7$ days & Cefditoren ${ }^{\mathrm{a}} 400 \mathrm{mg} / 12 \mathrm{~h}, 5$ days \\
\hline & H. influenzae & & Levofloxacinc $500 \mathrm{mg} / \mathrm{d}, 5-7$ days \\
\hline & M. pneumoniae & & Moxifloxacin ${ }^{\mathrm{c}} 400 \mathrm{mg} / \mathrm{d}, 5-7$ days \\
\hline \multirow{4}{*}{$\begin{array}{l}\text { Non severe CAP in }<65 \text { years, with } \\
\text { significant chronic morbidity or other risk } \\
\text { factors for infection with Gram-negatives }\end{array}$} & S. pneumoniae & Amoxicillin-clavulanic $875-125 \mathrm{mg} / 8 \mathrm{~h} \mathrm{5-7}$ days & Levofloxacin ${ }^{\mathrm{C}} 500 \mathrm{mg} / \mathrm{d}, 5-7$ dias \\
\hline & H. influenzae & + macrolide $^{b}$ & Moxifloxacin ${ }^{\mathrm{c}} 400 \mathrm{mg} / \mathrm{d}, 5-7$ dias \\
\hline & K. pneumoniae / other enterobacterial & Cefditoren $^{a} 400 \mathrm{mg} / 12 \mathrm{~h}, 5$ dias $+/$ - macrolide ${ }^{b}$ & \\
\hline & Legionella spp & & \\
\hline \multirow[t]{3}{*}{ CAP in COPD } & S. pneumoniae & Amoxicilin-clavulanate $875-125 \mathrm{mg} / 8 \mathrm{~h} \mathrm{5-7}$ days & \\
\hline & H. influenzae & $+\mid-$ macrolide $^{b}$ & \\
\hline & M. pneumoniae & Cefditoren $^{\mathrm{a}} 400 \mathrm{mg} / 12 \mathrm{~h}, 5$ dias & \\
\hline
\end{tabular}

*Dosing regimen correspond to current Spanish recommendations included in the guidelines and not that included in the summary of product characteristics:

alt should be prescribed if there is documented penicillin allergy or if the patient has been previously treated with amoxicillin or amoxicillin-clavulanate

${ }^{b}$ Add a macrolide (azithromycin $500 \mathrm{mg} / 24$ h, 3 days or clarithromycin $500 \mathrm{mg} / 12,7$ days) if there are risk factor or suspicion of L. pneumophila infection

'Only recommended when a macrolide is not possible

pects, such as: a) some third-generation oral cephalosporins with sufficient intrinsic activity against the most common respiratory pathogens, with comfortable dosage and good safety profile (e.g. cefditoren) are considered first line treatment option, particularly in patients older than 65 years. Moreover, it should be prescribed if a course of treatment with amoxicillin or amoxicillin-clavulanic acid has been used in the previous three months; b) the addition of a macrolide (azithromycin $500 \mathrm{mg} /$ day, oral for three days or clarithromycin $500 \mathrm{mg} / 12 \mathrm{~h}$ for seven days) should be considered if there are epidemiological risk factors or clinical suspicions of acquiring and developing infection with L. pneumophila or other "atypical" microorganisms and cannot be ruled out by rapid microbiological tests and c) use of fluoroquinolones only when beta-lactams cannot be used or when there is a need to cover certain microorganisms such as Gram-negative bacilli with resistance mechanisms, e.g. P. aeruginosa.
Finally, the inclusion of a given antimicrobial family globally or an antibiotic in particular in an oral antibiotic treatment guideline for LRTIs should be made on the basis of good tolerance profile, low capacity for selection of resistance mechanisms and minimal ecological impact, even assuming equal efficacy. Overall, beta-lactams have these characteristics and exceed the fluoroquinolone family in efficacy and tolerance, which are included as alternatives in LRTI guidelines and which have safety alerts by regulatory agencies $[54,55]$. The inclusion in these guidelines of certain third-generation oral cephalosporins, such as ceftditoren, with high efficacy and recognised tolerance, since they are not all the same, also helps to diversify the use of antibiotics, one of the pillars to minimise the selection of resistant and multiresistant bacteria. This is a key objective in the programmes to combat antimicrobial resistance and antimicrobial stewardship. 


\section{CONCLUSIONS}

The selection of oral antibiotics in LRTI should be based on knowledge of the bacterial aetiology and the frequency of local antimicrobial resistance, preferably those with a rapid mode of action, which achieve the greatest effect in the shortest time and with the fewest adverse effects (toxicity, interactions, resistance and/or ecological impact). Whenever possible, rotate and diversify antimicrobials and switch to the oral route as soon as possible. This Decalogue is intended as an aid to prescribing oral treatment for mild to moderate exacerbations of COPD and CAP. The concepts contained in this Decalogue are also contemplate in clinical treatment guideless.

\section{CONFLICTS OF INTEREST}

This manuscript has been written exclusively by the undersigned authors as part of an educational program funded by Meiji Pharma Spain, S.A. RC has participated in educational programs sponsored by Chiessi and Zambon. MS has participated in educational programs or given lectures sponsored by Angelini, Gilead, MSD and Pfizer. JGC received research grants, consultant/speaker honoraria as well as financial support for educational programs of his department from Thermofisher, Meiji, GlaxoSmithKline, Gilead, Roche, and Angelini. Other authors do not declare conflicts of interest

\section{REFERENCES}

1. Dekker AR, Verheij TJ, van der Velden AW. Inappropriate antibiotic prescription for respiratory tract indications: most prominent in adult patients. Fam Pract. 2015;32:401-7. doi: 10.1093/fampra/ cmv019.

2. González del Castillo J, Candel FJ, de la Fuente J, Gordo F, MartínSánchez FJ, Menéndez $R$, et al. Manejo integral del paciente con exacerbación aguda de la enfermedad pulmonar. Rev Esp Quimioter. 2018; 31(5):461-484. PMID: 30284414.

3. Fernández-Urrusuno $R$, Meseguer Barros $C M$, Anaya-Ordóñez $S$, Borrego Izquierdo $Y$, Lallana-Álvarez MJ, Madridejos $\mathrm{R}$, et al. Patients receiving a high burden of antibiotics in the community in Spain: a cross-sectional study. Pharmacol Res Perspect. 2021; 9(1):e00692. doi: 10.1002/prp2.692.

4. Menéndez R, Cantón R, Garcia-Caballero A, Barberán J. Tres claves para seleccionar el antibiótico oral adecuado en las infecciones respiratorias. Rev Esp Quimioter. 2019; 32:497-515. PMID: 31795630.

5. Cantón R. Aspectos microbiológicos actuales de la infección respiratoria comunitaria más allá de la COVID-19. Rev Esp Quimioter. 2021; 34:81-92. doi: 10.37201/req/049.2021.

6. González del Castillo J, Julián-Jiménez A, Candel FJ. Neumonía comunitaria: selección del tratamiento empírico y terapia secuencial. Implicaciones del SARS-CoV-2. Rev Esp Quimioter. 2021; 34:599609. doi: $10.37201 / \mathrm{req} / 144.2021$.

7. Rodríguez González-Moro JM, Izquierdo Alonso JL. Tratamiento antibiótico oral de la exacerbación de la EPOC. Más allá de la
COVID-19. Rev Esp Quimioter. 2021; 34:429-40. doi:10.37201/ req/125.2021.j.

8. Barberán J, Barberán LC, de la Cuerda A. Seguridad en la selección del tratamiento antibiótico oral en las infecciones comunitarias, más allá de la COVID-19. Rev Esp Quimioter. 2021; 34:289-97. doi: 10.37201/req/087.202.

9. Clinical Practice Guideline for the Diagnosis and Treatment of Patients with Chronic Obstructive Pulmonary disease (COPD) - the Spanish COPD Guideline (GesEPOC). 2017 Version Working group of the GesEPOC Arch Bronconeumol 2017; 53(Supl 1):2-64. doi: 10.1016/j.arbres.2017.03.018.

10. Torres A, Cilloniz $C$, Niederman MS, Menéndez $R$, Chalmers JD, Wunderink RG, et al. Pneumonia. Nat Rev Dis Primers. 2021 Apr 8;7(1):25. doi:10.1038/s41572-021-00259-0.

11. Mathioudakis AG, Chatzimavridou-Grigoriadou $V_{1}$ Corlateanu A, Vestbo J. Procalcitonin to guide antibiotic administration in COPD exacerbations: a meta-analysis. Eur Respir Rev. 2017. doi: 10.1183/16000617.0073-2016.

12. Jones B, Waterer G. Advances in community-acquired pneumonia. Ther Adv Infect Dis. 2020 Nov 6;7:2049936120969607. doi: $10.1177 / 2049936120969607$.

13. Ito $A$, Ishida T. Diagnostic markers for community-acquired pneumonia. Ann Transl Med. 2020 May;8(9):609. doi: 10.21037| atm.2020.02.182.

14. Anthonisen NR, Manfreda J, Warren $C P$, Hershfield ES, Harding GK,Nelson NA. Antibiotic therapy in exacerbations of chronic obstructive pulmonary disease. Ann Intern Med. 1987;106:196-204. doi:10.7326/0003-4819-106-2-196

15. Miravitlles M, Moragas A, Hernández S, Bayona C, Llor C. Is it possible to identify exacerbations of mild to moderate COPD that do not require antibiotic treatment? Chest. 2013; 44:1571-7. doi: 10.1378/ chest.13-0518

16. Soler-Cataluña JJ, Piñera P, Trigueros JA, Calle M, Casanova C, Cosío BG, et al. Spanish COPD Guidelines (GesEPOC) 2021 Update Diagnosis and Treatment af COPD Exacerbation Syndrome. Arch Bronconeumol. 2021 May 26:S0300-2896(21)00166-6. doi: 10.1016/j. arbres.2021.05.011.

17. Soler N, Agusti C, Angrill J, Puig de la Bellacasa J, Torres A. Bronchoscopic validation of the significance of sputum purulence in severe exacerbations of chronic obstructive pulmonary disease. Thorax. 2007; 62:29-35. doi: 10.1136/thx.2005.056374.

18. Woodhead M, Blasi F, Ewig S, Garau J, Huchon G, leven M, Ortqvist A, Schaberg T, Torres A, van der Heijden G, Read R, Verheij TJ; Joint Taskforce of the European Respiratory Society and European Society for Clinical Microbiology and Infectious Diseases. Guidelines for the management of adult lower respiratory tract infections--full version. Clin Microbiol Infect. 2011; 17 (Suppl 6):E1-59. doi: 10.1111/j.1469-0691.2011.03672.x.

19. Jain $S$, Self WH, Wunderink RG, Fakhran $S$, Balk R, Bramley AM, et al. Community-acquired pneumonia requiring hospitalization among U.S. Adults. N Engl J Med. 2015; 373:415-27. doi: 10.1056/ NEJMoa1500245.

20. González-Castillo J, Martín-Sánchez FJ, Llinares P, Menéndez R, 
Mujal A, Navas $E_{1}$ et al. Guidelines for the management of community-acquired pneumonia in the elderly patient. Rev Esp Quimioter. 2014; 27:69-86. PMID: 24676248.

21. Carugati M, Aliberti S, Sotgiu G, Blasi F, Gori A, Menendez R, et al. Bacterial etiology of community-acquired pneumonia in immunocompetent hospitalized patients and appropriateness of empirical treatment recommendations: an international point-prevalence study. Eur J Clin Microbiol Infect Dis. 2020; 39:1513-25.

22. Shorr AF, Zilberberg MD, Reichley R, Kan J, Hoban A, Hoffman J, et al. Validation of a clinical score for assessing the risk of resistant pathogens in patients with pneumonia presenting to the emergency department. Clin Infect Dis. 2012; 54:193-8. doi: 10.1093/cid/ cir813.

23. Lopez-Campos JL, Miravitlles $M$, de la Rosa Carrillo D, Cantón R, Soler-Cataluña JJ, Martinez-Garcia MA. Current challenges in chronic bronchial infection in patients with chronic obstructive pulmonary disease. J Clin Med. 2020 May 28;9(6):1639. doi: 10.3390/jcm9061639.

24. Ditz B, Christenson S, Rossen J, Brightling C, Kerstjens HAM, van den Berge M, Faiz A. Sputum microbiome profiling in COPD: beyond singular pathogen detection. Thorax. 2020; 75:338-44. doi: 10.1136/thoraxjnl-2019-214168.

25. Welp AL, Bomberger JM. Bacterial community interactions during chronic respiratory disease. Front Cell Infect Microbiol. 2020 May 14; 10:213. doi: 10.3389/fcimb.2020.00213.

26. Garcia-Clemente $M$, de la Rosa $D$, Máiz L, Girón R, Blanco M, Olveira

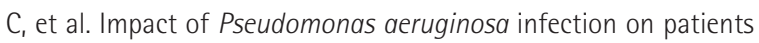
with chronic inflammatory airway diseases. J Clin Med. 2020 24; 9(12):3800. doi: 10.3390/jcm9123800.

27. Caverly $\sqcup$, Huang YJ, Sze MA. Past, present, and future research on the lung microbiome in inflammatory airway disease. Chest. 2019; 156:376-82. doi:10.1016/j.chest.2019.05.011.

28. Miravitlles $M_{1}$ Anzueto A. Chronic respiratory infection in patients with chronic obstructive pulmonary disease: What is the role of antibiotics? Int J Mol Sci. 2017 Jun 23;18(7):1344. doi: 10.3390/ ijms18071344.

29. Julián-Jiménez $A$, Adán Valero I, Beteta López A, Cano Martín LM, Fernández Rodríguez 0, Rubio Díaz R, et al. Recomendaciones para la atención del paciente con neumonía adquirida en la comunidad en los Servicios de Urgencias. Rev Esp Quimioter. 2018; 31:186202. PMID: 29619807;

30. Menéndez R, Cilloniz C, España, Almiralle J, Uranga U, Méndez R, Rigauf $R$, Torres A. Community-Acquired Pneumonia. Spanish Society of Pulmonology and Thoracic Surgery (SEPAR) Guidelines. 2020 Update. Arch Bronconeumol. 2020; 56 (Suppl 1):1-10. doi: 10.1016/j. arbres.2020.01.014.

31. Julián-Jiménez A. Manual de protocolos y actuación en urgencias. 5a Edición, 2021 (https://toledo.sanidad.castillalamancha.es/sites/ toledo.sescam.castillalamancha.es/files/publicaciones/08/07/2021/ manual_de_urgencias.pdf)

32. InfurgSEMES. Guía de antibioterapia empírica en infecciones prevalentes 2021 (http://www.infurg-semes.org/)

33. Mensa J, Soriano A, López-Suñé E, Llinares $P$, Barberán J, Zboro- myrska Y. Guia de terapéutica antimicrobiana. Ed. 2021. Editorial ANTARE. ISBN: 9788488825339.

34. Molero JM, Azcoaga A, Muñoz J. Los principales problemas en salud: Infecciones frecuentes en atención primaria (I). AMF 2021; 17(3):124-33. Disponible: https://amf-semfyc.com/web/article/2904

35. Guía de uso de antimicrobianos en adultos con tratamiento ambulatorio v3. Madrid: Consejería de Sanidad, Servicio Madrileño de Salud; diciembre 2021. Disponible en: https://www.comunidad.madrid/publicacion/ref/50515

36. Memoria (2020) de la red de vigilancia EARS-Net. Resultados de los hospitales españoles participantes en la Red. European Antimicrobial Resistance Surveillance Network. https://www.isciii.es/ QuienesSomos/CentrosPropios/CNM/ResistenciasAntibacterianas/ Investigacion/SiteAssets/Paginas/OtrosResultados/Memoria\%20 EARS-Net-2020.pdf

37. Fernández-Delgado L, Càmara J, González-Díaz A, Grau I, Shoji H, Tubau F, et al. Martí S, Serotypes in adult pneumococcal pneumonia in Spain in the era of conjugate vaccines. Microorganisms. 2021 Oct 28;9(11):2245. doi: 10.3390/microorganisms9112245.

38. Fenoll A, Granizo JJ, Giménez MJ, Yuste J, Aguilar L. Secular trends (1990-2013) in serotypes and associated non-susceptibility of $S$. pneumoniae isolates causing invasive disease in the pre-/post-era of pneumococcal conjugate vaccines in Spanish regions without universal paediatric pneumococcal vaccination. Vaccine. 2015; 33:5691-9. doi:10.1016/j.vaccine.2015.08.009.

39. Giménez MJ, Aguilar L, Granizo JJ. Revisiting cefditoren for the treatment of community-acquired infections caused by human-adapted respiratory pathogens in adults. Multidiscip Respir Med. 2018 Nov 2;13:40. doi: 10.1186/s40248-018-0152-5.

40. García-Cobos $S$, Arroyo M, Pérez-Vázquez M, Aracil B, Lara N, Oteo $J$, et al. Isolates of -lactamase-negative ampicillin-resistant Haemophilus influenzae causing invasive infections in Spain remain susceptible to cefotaxime and imipenem. J Antimicrob Chemother. 2014; 69:111-6. doi: 10.1093/jac/dkt324.

41. Carrera-Salinas A, González-Díaz A, Calatayud L, Mercado-Maza J, Puig C, Berbel D, et al. Epidemiology and population structure of Haemophilus influenzae causing invasive disease. Microb Genom. 2021; 7(12). doi: 10.1099/mgen.0.000723.

42. Domenech A, Tirado-Vélez JM, Fenoll A, Ardanuy C, Yuste J, Liñares $J$, et al. Fluoroquinolone-resistant pneumococci: dynamics of serotypes and clones in Spain in 2012 compared with those from 2002 and 2006. Antimicrob Agents Chemother. 2014; 58:2393-9. doi: 10.1128/AAC.02669-13.

43. Puig C, Tirado-Vélez JM, Calatayud L, Tubau F, Garmendia J, Ardanuy $C_{1}$ et al. Molecular characterization of fluoroquinolone resistance in nontypeable Haemophilus influenzae clinical isolates. Antimicrob Agents Chemother. 2015; 59:461-6. doi: 10.1128/AAC.04005-14.

44. Canton R. Resistance trends in Moraxella catarrhalis (PROTEKT years 1-3 [1999-2002]). J Chemother. 2004 Dec;16 Suppl 6:63-70. doi:10.1080/1120009x.2004.11782403.

45. Kyd JM, McGrath J, Krishnamurthy A. Mechanisms of bacterial resistance to antibiotics in infections of COPD patients. Curr Drug 
Targets. 2011; 12(4):521-30. doi: 10.2174/138945011794751519.

46. Waites KB, Xiao L, Liu Y, Balish MF, Atkinson TP. Mycoplasma pneumoniae from the respiratory tract and beyond. Clin Microbiol Rev. 2017; 30:747-809. doi: 10.1128/CMR.00114-16.

47. Martinez-Garcia MA, de la Rosa D, Cantón R, Olveira C, Máiz-Carro $L$, Girón $R$, et al. Bronchiectasis: when the published scientific evidence proves Insufficient. Arch Bronconeumol. 2019; 55:283-5. doi: 10.1016/j.arbres.2019.05.001.

48. Peterson $L R$, Shanholtzer $C J$. Tests for bactericidal effects of antimicrobial agents: technical performance and clinical relevance. Clin Microbiol Rev. 1992; 5:420-32. doi: 10.1128/CMR.5.4.420.

49. González del Castillo J et al. Gestión del arsenal antibiótico. Monografias Emergencias, 2014, vol. 8; n²:1-8.

50. García-Lamberechts EJ, González-Del Castillo J, Hormigo-Sánchez Al, Núñez-Orantos MJ, Candel FJ, Martín-Sánchez FJ. Factores predictores del fracaso al tratamiento antibiótico empírico. An Sist Sanit Navar. 2017;40(1):119-130. doi: 10.23938/ASSN.0011. PMID: 28534544.

51. Barberan J, Cantón R, Menéndez R, Calleja MA, Gonzalez del Castillo J, Díaz $\mathrm{S}$, et al. El valor de Cefditoreno en la infección respiratoria. Disponible en: http://www.infurg semes.org/PDF/Cefditoreno_monografico.pdf

52. Mezzatesta ML, Gona F, Marchese G, Nicolosi D, Toscano MA, Stefani $S$, et al. Cefditoren versus community-acquired respiratory pathogens: time-kill studies. J Chemother. 2009; 21:378-82. doi: 10.1179/joc.2009.21.4.378.

53. Di Marco F, Braido F, Santus P, Scichilone N, Blasi F. The role of cefditoren in the treatment of lower community-acquired respiratory tract infections (LRTIs): from bacterial eradication to reduced lung inflammation and epithelial damage. Eur Rev Med Pharmacol Sci. 2014; 18:321-32. PMID: 24563430.

54. Blasi F, Tarsia P, Mantero M, Morlacchi LC, Piffer F. Cefditoren versus levofloxacin in patients with exacerbations of chronic bronchitis: serum inflammatory biomarkers, clinical efficacy, and microbiological eradication. Ther Clin Risk Manag. 2013; 9: 55-64. doi: 10.2147/TCRM.S41131.

55. Food and Drugs Administration. FDA Drug Safety Communication: FDA advises restricting fluoroquinolone antibiotic use for certain uncomplicated infections; warns about disabling side effects that can occur together https://www.fda.gov/drugs/drug-safety-and-availability/fda-drug-safety-communication-fda-advises-restricting-fluoroquinolone-antibiotic-use-certain (accessed January 5, 2022)

56. European Medicines Agency. Disabling and potentially permanent side effects lead to suspension or restrictions of quinolone and fluoroquinolone antibiotics. https://www.ema.europa.eu/en/documents/referral/quinolone-fluoroquinolone-article-31-referral-disabling-potentially-permanent-side-effects-lead_en.pdf (accessed January 5, 2022)

57. Arulkumaran N, Routledge M, Schlebusch S, Lipman J, Conway Morris A. Antimicrobial associated harm in critical care: a narrative review. Intensive Care Med 2020; 46:225-235. doi.org/10.1007/ s00134-020-05929-3.
58. Pai MP, Momary KM; Rodvold KA. Antibiotic drug interactions. Med Clin North Am 2006; 90:1223-55. doi: 10.1016/j.mcna.2006.06.008.

59. White AR, Kaye C, Poupard J, Pypstra R, Woodnutt G, Wynne B. Augmentin (amoxicillin/clavulanate) in the treatment of community-acquired respiratory tract infection: a review of the continuing development of an innovative antimicrobial agent. J Antimicrob Chemother 2004; 53(Suppl 1):i3-i20. doi: 10.1093/jac/ dkh050.

60. Lagace-Wiens $P$, Rubinstein E. Adverse reactions to beta-lactam antimicrobials. Expert Opin Drug Saf. 2012; 11:381-399. doi: 10.1517/14740338.2012.643866

61. Tandan M, Cormican M, Vellinga A. Adverse events of fluoroquinolones vs. other antimicrobials prescribed in primary care: $\mathrm{A}$ systematic review and me- ta-analysis of randomized controlled trials. Int J Antimicrob Agents. 2018 52:529-40. doi: 10.1016/j.ijantimicag.2018.04.014.

62. Pasquau J, Matesanz M. Duración del tratamiento antibiótico. Rev Esp Quimioter. 2015; 28 (Suppl 1):30-3. PMID: 26365731.

63. Giacomini E, Perrone V, Alessandrini D, Paoli D, Nappi C, Degli Esposti L. Evidence of antibiotic resistance from population-based studies: A narrative review. Infect Drug Resist. 2021; 14:849-58. doi: 10.2147/IDR.S289741.

64. Del Mar C, Looke DFM. Should we abandon "finishing the course" of antimicrobials? BMJ. 2017 Sep 22; 358:j4170. doi: 10.1136/bmj. j4170.

65. Llewelyn MJ, Fitzpatrick JM, Darwin E, SarahTonkin-Crine, Gorton C, Paul J, et al. The antibiotic course has had its day. BMJ. $2017 \mathrm{Jul}$ 26;358:j3418. doi: 10.1136/bmj.j3418.

66. Spellberg B. The maturing antibiotic mantra: "Shorter is still better". J Hosp Med. 2018 May 1; 13(5):361.362. doi: 10.12788/jhm.2904.

67. Dawson-Hahn EE, Mickan S, Onakpoya I, Roberts N, Kronman M, Butler CC, et al. Short-course versus long-course oral antibiotic treatment for infections treated in outpatient settings: a review of systematic reviews. Fam Pract. 2017; 34:511-9. doi: 10.1093/ fampra/cmx037.

68. Palin V, Welfare W, Ashcroft DM, van Staa TP. Shorter and longer courses of antibiotics for common infections and the association with reductions of infection-related complications including hospital admissions. Clin Infect Dis. 2021; 73:1805-12. doi: 10.1093/ cid/ciab159.

69. Royer S, DeMerle KM, Dickson RP, Prescott HC. Shorter versus longer courses of antibiotics for infection in hospitalized patients: A systematic review and meta-analysis. J Hosp Med. 2018; 13:336342. doi: 10.12788/jhm.2905.

70. Smith BJ, Heriot G, Buising K. Antibiotic treatment of common infections: more evidence to support shorter durations. Curr Opin Infect Dis. 2020; 33:433-40. doi:10.1097/0C0.0000000000000680.

71. Wald-Dickler N, Spellberg B. Short-course antibiotic therapy-replacing constantine units with "shorter is better". Clin Infect Dis. 2019; 69:1476-9. doi: 10.1093/cid/ciy1134.

72. Lee RA, Centor RM, Humphrey LL, Jokela JA, Andrews R, Qaseem A, et al. Appropriate use of short-course antibiotics in common infections: best practice advice from the American College of Physicians. Ann Intern Med. 2021; 174:822-7. doi: 10.7326/M20-7355. 
73. Cantón R, Morosini MI. Emergence and spread of antibiotic resistance following exposure to antibiotics. FEMS Microbiol Rev. 2011; 35:977-91. doi: 10.1111/j.1574-6976.2011.00295.x

74. Sethi S, Anzueto A, Miravitlles M, Arvis P, Alder J, Haverstocky D et al. Determinants of bacteriological outcomes in exacerbations of chronic obstructive pulmonary disease. Infection, 2016; 44:65-76. doi: 10.1007/s15010-015-0833-3.

75. Giménez MJ, Aguilar L, Granizo JJ. Revisiting cefditoren for the treatment of community-acquired infections caused by human-adapted respiratory pathogens in adults. Multidiscip Respir Med. 2018 Nov 2;13:40. doi: 10.1186/s40248-018-0152-5.

76. Sullivan A, Edlund C, Nord CE. Effect of antimicrobial agents on the ecological balance of human microflora. Lancet Infect Dis. 2001; 1:101-14.

77. Jernberg C, Löfmark S, Edlund C, Jansson JK. Long-term impacts of antibiotic exposure on the human intestinal microbiota. Microbiology. 2010; 156(Pt 11):3216-3223. doi: 10.1099/ mic.0.040618-0.

78. Zimmermann $\mathrm{P}$, Curtis $\mathrm{N}$. The effect of antibiotics on the composition of the intestinal microbiota - a systematic review. J Infect. 2019;79(6):471-489. doi: 10.1016/j.jinf.2019.10.008.

79. Vardakas KZ, Trigkidis KK, Boukouvala E, Falagas ME. Clostridium difficile infection following systemic antibiotic administration in randomised controlled trials: a systematic review and meta-analysis. Int J Antimicrob Agents. 2016; 48:1-10. doi: 10.1016/j.ijantimicag.2016.03.008.

80. Wilcox MH, Chalmers JD, Nord CE, Freeman J, Bouza E. Role of cephalosporins in the era of Clostridium difficile infection. J Antimicrob Chemother. 2017; 72:1-18. doi: 10.1093/jac/dkw385.

81. Gerding DN, Larson TA, Hughes RA, Weiler M, Shanholtzer C, Peterson LR. Aminoglycoside resistance and aminoglycoside usage: ten years of experience in one hospital. Antimicrob Agents Chemother. 1991; 35:1284-90. doi:10.1128/AAC.35.7.1284.

82. Goulart CP, Mahmudi M, Crona KA, Jacobs SD, Kallmann M, Hall $B G$, et al. Designing antibiotic cycling strategies by determining and understanding local adaptive landscapes. PLOS One. 2013; 8(2):e56040. doi: 10.1371/journal.pone.0056040.

83. John JF Jr, Rice LB. The microbial genetics of antibiotic cycling. Infect Control Hosp Epidemiol. 2000; 21(1 Suppl):S22-31. doi: 10.1086/503170.

84. Cobos-Trigueros N, Solé M, Castro P, Torres JL, Rinaudo M, De Lazzari $E_{1}$ et al. Evaluation of a mixing versus a cycling strategy of antibiotic use in critically-ill medical patients: impact on acquisition of resistant microorganisms and clinical outcomes. PLoS One. 2016; 11(3):e0150274. doi: 10.1371/journal.pone.0150274.

85. Candel FJ, Julián-Jiménez A, González-Del Castillo J. Current status in outpatient parenteral antimicrobial therapy: a practical view. Rev Esp Quimioter. 2016; 29:55-68. PMID: 27014770.

86. Ramos Lázaro J, Chico $C$, Jove N, Blázquez Fernández $A B$, Fernández Monasterio MM, Smithson A. Tratamiento antimicrobiano domiciliario endovenoso en hombres con infección del tracto urinario febril: diferencias entre el modelo de evitación de ingreso y el de alta precoz hospitalaria. Emergencias. 2021; 33:399-402. PMID: 34581537.
87. Halm EA, Fine MJ, Marrie TJ, Coley CM, Kapoor WN, Obrosky DS, et al. Time to clinical stability in patients hospitalized with community-acquired pneumonia: implications for practice guidelines. JAMA. 1998; 279:1452-7. doi: 10.1001/jama.279.18.1452

88. Menéndez R, Torres A, Aspa J, Capelastegui A, Prat C, Rodríguez de Castro F. Neumonía adquirida en la comunidad. Nueva normativa de la Sociedad Española de Neumología y Cirugía Torácica (SEPAR). Arch Bronconeumol. 2010; 46(10):543-58. doi: 10.1016/j. arbres.2010.06.014.

89. Miravitlles M, Soler-Cataluña JJ, Calle M, Molina J, Almagro P, Quintano JA, et al. Spanish Guidelines for Management of Chronic Obstructive Pulmonary Disease (GesEPOC) 2017. Pharmacological Treatment of Stable Phase. Arch Bronconeumol. 2017; 53(6): 32435. doi: 10.1016/j.arbres.2017.03.018.

90. González del Castillo J, Candel FJ, de la Fuente J, Gordo F, MartínSánchez FJ, Menéndez R, et al. Manejo integral del paciente con exacerbación aguda de la enfermedad pulmonar. Rev Esp Quimioter. 2018; 31:461-84. PMID: 30284414. 
Lorenzo Cantarelli

Fernando Gutiérrez Nicolás

Gloria Julia Nazco Casariego

Sara García Gil

\section{Adecuación a las recomendaciones diagnósticas en pacientes con neumonía por Pneumocystis jirovecii tratados con pentamidina intravenosa}

Servicio de Farmacia. Complejo Hospitalario Universitario de Canarias, Tenerife (España).

Article history

Received: 23 April 2021; Revision Requested: 16 July 2021; Revision Received: 13 August 2021; Accepted: 5 October 2021;

Published: 1 December 2021

\section{RESUMEN}

Objetivos. Determinar la tasa de confirmación microbiológica en el diagnóstico de la neumonía por Pneumocystis jirovecii en pacientes tratados con pentamidina intravenosa y la potencial correlación con la efectividad y seguridad del tratamiento.

Material y métodos. Estudio retrospectivo unicéntrico (2010-2020), que incluyó aquellos pacientes que recibieron tratamiento con pentamidina intravenosa durante al menos 48 horas. Se registró el procedimiento de recogida de la muestra y el análisis microbiológico realizado. Se determinó la eficacia según la tasa de mortalidad a los 14 días e ingreso en Unidad de Vigilancia Intensiva (UVI), y el control de la enfermedad, mediante la duración de estancia hospitalaria y tiempo desde la finalización del tratamiento hasta el alta. El perfil de seguridad se evaluó según la Common Terminology Criteria for Adverse Events (CTCAE) v5.0.

Resultados. Un total de 17 pacientes con neumonía por $P$. jirovecii fueron tratados con pentamidina $(76,5 \%$ hombres $(n=13)$; edad media [desviación estándar]: 58,6 [15,5]).

En el 47,1\% (n=8) de los casos se estableció una confirmación microbiológica del patógeno. El empleo dirigido con pentamidina redujo de forma significativa el tiempo desde la finalización del tratamiento hasta el alta hospitalaria $(p=0,019)$. El perfil de seguridad fue aceptable, apareciendo toxicidad grado I en un paciente.

Conclusiones. El estudio muestra como más del 50\% de los pacientes reciben tratamiento a partir de un diagnóstico presuntivo y sin ajustarse a las recomendaciones establecidas, repercutiendo en la duración de ingreso y recuperación del pa-

Correspondencia:

Lorenzo Cantarelli

Servicio de Farmacia. Complejo Hospitalario Universitario de Canarias, Tenerife (España). Carretera Ofra s/n, La Laguna (Tenerife); Código postal: 38320

Teléfono: 922678038

E-mail: Lorenzo.adeje@gmail.com ciente. Serán necesarios futuros estudios con un mayor tamaño muestral para consolidar los resultados obtenidos.

Palabras clave: Pneumocystis jirovecii; Diagnóstico; pentamidina

\section{Adequacy to diagnostic recommendations in patients with Pneumocystis jirovecii pneumonia treated with intravenous pentamidine}

\section{ABSTRACT}

Objectives. To determine the rate of microbiological confirmation in the diagnosis of Pneumocystis jirovecii pneumonia in patients treated with intravenous pentamidine and the potential correlation with treatment effectiveness and safety.

Material and methods. Single-centre retrospective study (2010-2020), which included those patients who received intravenous pentamidine treatment for at least 48 hours. The sample collection procedure and the microbiological analysis performed were recorded. Efficacy was determined by 14-day mortality rate and admission to the Intensive Care Unit (ICU), and disease control was determined by length of hospital stay and time from completion of treatment to discharge. The safety profile was assessed according to the Common Terminology Criteria for Adverse Events (CTCAE) v5.0.

Results. A total of 17 patients with $P$. jirovecii pneumonia were treated with pentamidine $(76.5 \%$ male $(n=13)$; mean age [standard deviation]: 58.6 [15.5]). Microbiological confirmation of the pathogen was established in $47.1 \%(n=8)$ of cases. Targeted use of pentamidine significantly reduced the time from treatment completion to hospital discharge $(p=0.019)$. The safety profile was acceptable, with grade I toxicity occurring in one patient.

Conclusions. The study shows that more than 50\% of patients receive treatment based on a presumptive diagnosis and without adhering to the established recommendations, 
with repercussions on the duration of admission and recovery of the patient. Future studies with a larger sample size will be necessary to consolidate the results obtained.

Keywords: Pneumocystis jirovecii; Diagnostic; pentamidine.

\section{INTRODUCCIÓN}

Pneumocystis jirovecii es considerado uno de los agentes etiológicos más prevalentes a nivel mundial en el desarrollo de infecciones oportunistas $[1,2]$. La presencia del patógeno se manifiesta a través de una neumonía micótica potencialmente mortal (PCP) en individuos altamente inmunocomprometidos. Si bien la tasa de incidencia de la PCP en pacientes diagnosticados del virus de la inmunodeficiencia humana $(\mathrm{VIH})$ se ha reducido debido al desarrollo de nuevos tratamientos antirretrovirales de alta actividad (TARGA) [2], continúa manifestándose de forma asidua en pacientes oncohematológicos que reciben terapia inmunosupresora [2]. En este grupo poblacional, la PCP ha demostrado presentar una evolución más aguda y un pronóstico más desfavorable [3], alcanzando tasas de mortalidad del $35-55 \%$, en comparación con los pacientes VIH, cuyos porcentajes han reflejado ser inferiores (10-20\%) [4].

En la actualidad, la estrategia terapéutica estándar en el tratamiento y profilaxis en pacientes de alto riesgo, ha consistido en el empleo de la combinación antibiótica trimetoprimsulfametoxazol (TMP-SMX) $[5,6]$. Sin embargo, debido a la frecuente aparición de toxicidad asociada al uso de este fármaco, el empleo en práctica clínica del antimicótico pentamidina ha resultado ser equivalente en términos de efectividad como terapia alternativa en esta patología [7].

En práctica clínica, el abordaje óptimo de la patologia consiste en llevar a cabo, tras una primera sospecha diagnóstica de PCP en pacientes de alto riesgo, una confirmación microbiológica de la presencia del patógeno con el fin de poder instaurar un tratamiento dirigido efectivo. En este sentido, debido a las múltiples limitaciones para el aislamiento y cultivo de este patógeno, se ha establecido como técnica estándar de diagnóstico, junto a pruebas de imagen a nivel pulmonar, la realización de un examen microscópico a partir de métodos de tinción que permiten visualizar e identificar las estructuras morfológicas del patógeno [8]. La recogida de la muestra para su posterior análisis, se realiza a partir de muestras respiratorias del paciente obtenidas mediante técnicas de lavado broncoalveolar o esputo inducido [9].

Sin embargo, la escasa carga microbiológica obtenida, junto a la limitada especificidad de las pruebas de imagen y signos clinicos de la patologia, ha justificado el creciente uso de métodos diagnósticos de elevada sensibilidad y especificidad, entre los que destaca la inmunofluorescencia directa a partir del empleo de anticuerpos monoclonales dirigidos frente a las glicoproteinas de superficie $[10,11]$, asi como técnicas moleculares basadas en la reacción en cadena de la polimerasa (PCR) [12]. En este contexto, la PCR cuantitativa en tiempo real (qPCR-rt), una de las técnicas más avanzadas, aunque menos disponible en la mayoría de los centros hospitalarios, ha de- mostrado ser el método más apropiado para la cuantificación del material genético y diagnóstico del patógeno $[13,14]$.

Debido a la elevada morbimortalidad asociada a esta patología infecciosa [4], las principales guías clínicas establecen la posibilidad de la instauración del tratamiento empírico preCoz [15] y una posterior confirmación microbiológica de misma. No obstante, en situaciones de práctica clínica habitual, tras recibir una primera pauta terapéutica empírica, en un reducido número de casos se lleva a cabo un diagnóstico definitivo por confirmación microbiológica del patógeno durante el ingreso. Como consecuencia, un elevado porcentaje de pacientes inmunodeprimidos con alta sospecha de PCP, reciben tratamiento con pentamidina a partir de un diagnóstico meramente presuntivo e inespecifico [16], lo que puede repercutir sobre el control de la enfermedad, así como en la efectividad y seguridad del tratamiento, en aquellos pacientes con signos de infección moderado-graves $[15,17]$.

Por todo ello, el objetivo principal del presente estudio ha consistido en determinar la tasa de adecuación diagnóstica mediante confirmación microbiológica, en pacientes con una alta sospecha de infección por $P$. jirovecii tratados con pentamidina, y evaluar su potencial implicación en el control de la enfermedad, efectividad y seguridad del tratamiento en práctica clínica.

\section{MATERIAL Y METODOS}

Diseño del estudio. Se trata de un estudio retrospectivo y unicéntrico, que incluyó a todos aquellos pacientes que recibieron tratamiento con pentamidina intravenosa (IV), durante al menos 48 horas, por diagnóstico confirmado o sospecha de neumonía por Pneumocysits jirovecii (PCP) en un periodo comprendido entre enero 2010 y enero 2020. Se definió como cumplimiento de los criterios diagnósticos a la confirmación de la presencia del patógeno mediante el empleo de técnicas microbiológicas y moleculares. Se llevó a cabo un análisis de subgrupos, identificando aquellos pacientes cumplidores de los criterios diagnósticos establecidos de PCP (grupo dPCP) y aquellos que recibieron tratamiento a partir de una simple prueba de imagen, en ausencia de una confirmación diagnostica especifica durante la estancia hospitalaria (grupo ePCP).

Diagnóstico etiológico. Se registró en cada caso, el procedimiento de recogida de muestra para la identificación del patógeno: lavado broncoalveloar y esputo inducido. Asimismo, se determinó el tipo de técnica empleada para el posterior estudio microbiológico: tinción en frotis (técnica de GomoriGrocott), inmunofluorescencia directa y PCR.

Efectividad y perfil de seguridad del tratamiento. Se analizó la correlación entre la presencia de una confirmación microbiológica del patógeno y la efectividad del tratamiento, a partir de la variable de mortalidad bruta a los 14 dias tras la finalización del tratamiento y necesidad de ingreso en la unidad de vigilancia intensiva (UVI). Asimismo, se analizaron las variables subrogadas correspondientes a la duración total de 


\begin{tabular}{|c|c|c|c|}
\hline \multirow[t]{2}{*}{ Tabla 1} & \multicolumn{3}{|c|}{ Características basales de los pacientes. } \\
\hline & Total & ePCP & $\mathrm{dPCP}$ \\
\hline Pacientes, n (\%) & 17 & $9(52,9)$ & $8(47,1)$ \\
\hline \multicolumn{4}{|l|}{ Edad (años) } \\
\hline Media (DE) & $58,6(15,5)$ & $62,2(13,8)$ & $54,5(17,2)$ \\
\hline Rango & $27-79$ & $35-79$ & $27-79$ \\
\hline \multicolumn{4}{|l|}{ Sexo, n $(\%)$} \\
\hline Hombres & $13(76,5)$ & $7(77,8)$ & $6(75,0)$ \\
\hline Mujeres & $4(23,5)$ & $2(22,2)$ & $2(25,0)$ \\
\hline \multicolumn{4}{|c|}{ Patología basal, $n(\%)$} \\
\hline Linfoma & $3(17,6)$ & $1(11,1)$ & $2(25,0)$ \\
\hline SMD & $2(11,7)$ & $2(22,2)$ & $0(0,0)$ \\
\hline VIH & $6(35,3)$ & $2(22,2)$ & $4(50,0)$ \\
\hline Otra & $6(35,3)$ & $4(44,4)$ & $2(25,0)$ \\
\hline \multicolumn{4}{|c|}{ Tratamiento previo, n (\%) } \\
\hline TMP-SMX & $13(76,5)$ & $5(55,6)$ & $8(100)$ \\
\hline
\end{tabular}

DE: desviación estándar; PCP: Neumonía por P. jirovecii; SMD: síndrome mielodisplásico; TMP-SMX: trimetoprim-sulfametoxazol; VIH: virus de la inmunodeficiencia humana; ePCP: grupo de pacientes que recibieron tratamiento en ausencia de una confirmación diagnostica específica durante la estancia hospitalaria; dPCP: pacientes cumplidores de los criterios diagnósticos establecidos de PCP.

estancia hospitalaria, así como el tiempo desde la finalización del tratamiento hasta el alta hospitalaria.

Se evaluó el perfil de seguridad del tratamiento con pentamidina, registrando la tasa de efectos adversos durante su administración, siguiendo los criterios de la Common Terminology Criteria for Adverse Events (CTCAE) v5.0.

Análisis estadístico. Las comparaciones entre las variables continuas del estudio, expresadas como promedios y desviación estándar (DE), se realizaron a partir del método estadístico de U-Mann Whitney. Se consideró significación estadística a un valor de $p<0,05$, con un IC 95\%. Todos Ios análisis se realizaron con la ayuda del programa estadístico SPSS ${ }^{\circledR}$ IBM (Statistical Package for the Social Sciences) versión 25.0. El estudio contó con la aprobación del Comité Ético del Hospital Universitario de Canarias.

\section{RESULTADOS}

Durante el periodo de estudio, un total de 22 pacientes con diagnóstico de PCP cursaron tratamiento con pentamidina intravenosa. Fueron excluidos 5 pacientes debido a una duración de tratamiento inferior a $48 \mathrm{~h}$, incluyéndose un total de 17 pacientes en el análisis final. Las características basales de los pacientes se detallan en la tabla 1. En el 23,5\% de los casos

\begin{tabular}{|c|c|c|c|c|}
\hline \multirow[t]{2}{*}{ Tabla 2} & \multicolumn{4}{|c|}{$\begin{array}{l}\text { Metodología de diagnóstico de la } \\
\text { neumonia por Pnemocystis jirovecii } \\
\text { (PCP). }\end{array}$} \\
\hline & & Total & ePCP & $\mathrm{dPCP}$ \\
\hline \multicolumn{5}{|c|}{ Técnica de toma de muestra microbiológica, $n(\%)$} \\
\hline BAL & & $6(35,3)$ & - & $6(75,0)$ \\
\hline Esputo inducido & & $1(5,9)$ & - & $1(12,5)$ \\
\hline Otra & & $1(5,9)$ & - & $1(12,5)$ \\
\hline \multicolumn{5}{|c|}{ Técnica de prueba diagnóstica, $n(\%)$} \\
\hline RX tórax & & $7(41,2)$ & $7(77,8)$ & - \\
\hline TACAR tórax & & $2(11,8)$ & $2(22,2)$ & - \\
\hline IFD & & $8(47,1)$ & $0(0,0)$ & $8(100,0)$ \\
\hline Tinción en frotis & Somori-Grocott) & $3(17,6)$ & $0(0,0)$ & $3(37,5)$ \\
\hline PCR & & $1(5,9)$ & $0(0,0)$ & $1(12,5)$ \\
\hline Cumplimiento de los & riterios diagnósticos, $\mathrm{n}(\%)$ & $8(47,1)$ & - & $8(100)$ \\
\hline
\end{tabular}

BAL: Lavado broncoalveolar; IFD: inmunofluorescencia directa; PCP: Neumonía por P. jirovecii; PCR: reacción en cadena de la polimerasa; RX: radiografía; TACAR: tomografía axial computarizada de alta resolución; ePCP: grupo de pacientes que recibieron tratamiento en ausencia de una confirmación diagnostica específica durante la estancia hospitalaria; dPCP: pacientes cumplidores de los criterios diagnósticos establecidos de PCP.

$(n=4)$ la pentamidina se administró como tratamiento de primera línea.

La metodología diagnóstica, incluyendo el procedimiento de toma de la muestra y las pruebas microbiológicas confirmatorias, se ha recogido en la Tabla 2. El análisis mostró como en el 47,1\% ( $n=8)$ de los casos se llevó a cabo una confirmación microbiológica según las pautas establecidas. En los casos restantes, la pentamidina se administró a partir de un diagnóstico del patógeno basado en pruebas de imagen altamente inespecíficas como una radiografía simple y/o tomografía axial computarizada de alta resolución (TACAR) de tórax, sin haberse efectuado una toma de muestra microbiológica de forma previa o posterior al inicio del tratamiento (Tabla 2).

Tal y como queda reflejado en la tabla 3, la administración de pentamidina en pacientes con una confirmación microbiológica de PCP (grupo dPCP) redujo de forma significativa el tiempo desde la finalización de la terapia con pentamidina hasta el alta hospitalaria $(p=0,019)$. Sin embargo, no se observaron mejorías en los parámetros correspondientes a tiempo de estancia hospitalaria global $(p=0,743)$, mortalidad bruta a los 14 dias tras la finalización del tratamiento $(p=0,201)$ y tasa de ingreso en UVI $(p=0,772)$.

El análisis del perfil de seguridad de pentamidina reveló que el fármaco fue seguro en el 94,1\% de los casos $(n=16)$, detectándose únicamente un evento de toxicidad gastrointestinal grado I, el cual no supuso la interrupción precoz del tratamiento. 


\begin{tabular}{|c|c|c|c|c|c|}
\hline \multirow[t]{2}{*}{ Tabla 3} & \multicolumn{5}{|c|}{$\begin{array}{l}\text { Análisis de eficacia y seguridad en el tratamiento con } \\
\text { pentamidina en grupo ePCP vs. } \mathrm{dPCP}\end{array}$} \\
\hline & & Total & ePCP & $\mathrm{dPCP}$ & p \\
\hline \multicolumn{6}{|c|}{ Duración de estancia hospitalaria (dias) } \\
\hline Media (DE) & & $35,8(19,8)$ & $40,2(25,8)$ & $30,8(9,0)$ & 0,743 \\
\hline Rango & & $8,0-75,0$ & $8,0-75,0$ & $21,0-45,0$ & - \\
\hline \multicolumn{6}{|c|}{ Duración de tratamiento con pentamidina IV (dias) } \\
\hline Media (DE) & & $13,7(11,8)$ & $17,0(14,3)$ & $10(7,4)$ & 0,200 \\
\hline Rango & & $2,0-50,0$ & $3,0-50,0$ & $2,0-21,0$ & - \\
\hline \multicolumn{6}{|c|}{$\begin{array}{l}\text { Tiempo desde la finalización del tratamiento hasta } \\
\text { el alta hospitalaria (dias) }\end{array}$} \\
\hline Media (DE) & & $11,9(12,4)$ & $23,0(12,3)$ & $4,5(4,8)$ & 0,019 \\
\hline Rango & & $0,0-34,0$ & $2,0-34,0$ & $0,0-13,0$ & \\
\hline Ingreso en UVI & & $7(41,2)$ & $4(44,4)$ & $3(37,5)$ & 0,772 \\
\hline $\begin{array}{l}\text { Mortalidad a lc } \\
\text { tratamiento, } n\end{array}$ & lías tras la finalización del & $7(41,2)$ & $5(55,6)$ & $2(25,0)$ & 0,201 \\
\hline Toxicidad, n (\% & & $1(5,9)$ & $0(0)$ & $1(12,5)$ & - \\
\hline
\end{tabular}

DE: desviación estándar; IV: intravenoso; PCP: Neumonía por P. jirovecii UVI: unidad de vigilancia intensiva; ePCP: grupo de pacientes que recibieron tratamiento en ausencia de una confirmación diagnostica específica durante la estancia hospitalaria; dPCP: pacientes cumplidores de los criterios diagnósticos establecidos de PCP.

\section{DISCUSIÓN}

Los individuos que presentan un sistema inmune altamente comprometido, como pacientes oncohematológicos y VIH, son considerados un grupo de alto riesgo para el desarrollo de infecciones oportunistas $[1,2]$, siendo la PCP una de las infecciones fúngicas invasivas más prevalentes en la actualidad y con una elevada tasa de morbimortalidad asociada $[3,4]$. A pesar del empleo de TMP- SMX como terapia de elección tanto para la profilaxis como para el tratamiento de la PCP $[5,6]$, la falta de respuesta o intolerancia al mismo, ha implementado el uso de pentamidina como una alternativa segura y efectiva en práctica clínica [7].

Si bien las principales guias de práctica clínica recomiendan la instauración de un tratamiento empírico precoz por la elevada morbimortalidad asociada a la patología infecciosa $[4,15]$, con el fin de llevar a cabo un apropiado abordaje terapéutico, resulta necesario llevar a cabo una posterior confirmación diagnóstica del patógeno que permita la administración de un tratamiento óptimo dirigido. En este contexto, debido a las considerables dificultades relacionadas con el cultivo del microorganismo, el diagnóstico confirmatorio debe establecerse a partir de técnicas microbiológicas y moleculares $[10,11,12]$. Sin embargo, la actual falta de protocolos rutinarios, conlleva a una limitación en el empleo de dichos métodos diagnósticos en la práctica clínica, sometiendo a los pacientes al tratamiento con pentamidina a partir de pruebas de imagen altamente inespecíficas [16], condicionando la efectividad y seguridad del mismo.

Con el presente trabajo, hemos querido reflejar como el empleo de las técnicas microbiológicas y moleculares de alta sensibilidad como método estándar de diagnóstico en pacientes con alta sospecha de infección por P. jirovecii tratados con pentamidina, permite un mejor control de la enfermedad, disminuyendo el tiempo de ingreso desde la finalización de la terapia con pentamidina hasta el alta hospitalaria $(p=0,019)$. No obstante, no se encontraron diferencias significativas en los parámetros de efectividad medidos en el estudio, no observándose una correlación entre la ausencia de un diagnóstico específico y un aumento de la mortalidad a los 14 dias tras la finalización del tratamiento antibiótico $(p=0,201)$ y necesidad de estancia en UVI $(p=0,772)$. Asimismo, debido a limitaciones en cuanto al carácter retrospectivo y al reducido tamaño muestral del estudio, las conclusiones extraídas deben ser tomadas con cierta cautela.

El presente trabajo muestra como en práctica clínica habitual, en menos de la mitad de los pacientes con una alta sospecha de PCP se lleva a cabo una confirmación microbiológica del patógeno. Este fenómeno, a pesar de haber demostrado no tener implicación directa en la mortalidad del paciente, puede dar lugar a potenciales complicaciones durante el ingreso, aumentando los tiempos de estancia hospitalaria. Por ello, los resultados obtenidos ponen en evidencia la urgente necesidad de incorporar de manera rutinaria protocolos para el diagnós- 
tico y análisis de muestras en aquellos pacientes con un alto riesgo de infección oportunista por $P$. jirovecii. Serán necesarios futuros estudios con un mayor número de pacientes para afianzar los resultados obtenidos.

\section{FINANCIACIÓN}

Los autores declaran que no han recibido financiación para la realización de este trabajo.

\section{CONFLICTO DE INTERESES}

Los autores declaran no tener conflictos de intereses.

\section{BIBLIOGRAFÍA}

1. Avino $\sqcup$, Naylor SM, Roecker AM. Pneumocystis jirovecii Pneumonia in the Non-HIV-Infected Population. Ann Pharmacother. 2016;50(8):673-9. doi: 10.1177/1060028016650107.

2. Cillóniz C, Dominedò C, Álvarez-Martínez MJ, Moreno A, García F, Torres $A$, et al.Pneumocystis pneumonia in the twenty-first century: HIV-infected versus HIV-uninfected patients. Expert Rev Anti Infect Ther . 2019;17(10):787-801. doi:10.1080/14787210.2019.16 71823

3. Salzer HJF, Schäfer G, Hoenigl M, Günther G, Hoffmann C, Kalsdorf $B$, et al. Clinical, Diagnostic, and Treatment Disparities between HIV-Infected and Non-HIV-Infected Immunocompromised Patients with Pneumocystis jirovecii Pneumonia. Respiration. 2018;96(1):52-65. doi: 10.1159/000487713

4. Rego de Figueiredo I, Vieira Alves R, Drummond Borges D, Torres $M$, Lourenço $F$, Antunes AM, et al. Pneumocystosis pneumonia: A comparison study between HIV and non-HIV immunocompromised patients. Pulmonology. 2019;25(5):271-4. doi: 10.1016/j.pulmoe.2019.04.003.

5. Huang YS, Yang JJ, Lee NY, Chen GJ, Ko WC, Sun HY, et al. Treatment of Pneumocystis jirovecii pneumonia in HIV-infected patients: a review. Expert Rev Anti Infect Ther. 2017;15(9):873-92. doi: 10.1080/14787210.2017.1364991

6. Cooley L, Dendle C, Wolf J, Teh BW, Chen SC, Boutlis C, et al. Consensus guidelines for diagnosis, prophylaxis and management of Pneumocystis jirovecii pneumonia in patients with haematological and solid malignancies, 2014. Intern Med J. 2014;44(12):1350-63. doi: 10.1111/imj.12599

7. Klein NC, Duncanson FP, Lenox TH, Forszpaniak C, Sherer $\mathrm{CB}$, Quentzel $\mathrm{H}$ et al. Trimethoprim-sulfamethoxazole versus pentamidine for Pneumocystis carinii pneumonia in AIDS patients: results of a large prospective randomized treatment trial.AIDS.1992. Mar;6(3):301-5. doi: 10.1097/00002030-199203000-00007.

8. Kato H, Samukawa S, Takahashi H, Nakajima H. Diagnosis and treatment of Pneumocystis jirovecii pneumonia in HIV-infected or non-HIV-infected patients difficulties in diagnosis and adverse effects of trimethoprim-sulfamethoxazole. J Infect Chemother. 2019;25(11):920-4. doi:10.1016/j.jiac.2019.06.007
9. Bateman M, Oladele R, Kolls JK. Diagnosing Pneumocystis jirovecii pneumonia: A review of current methods and novel approaches. Med Mycol. 2020;58(8):1015-28. doi: 10.1093/mmy/myaa024

10. Choe PG, Kang YM, Kim G, Park WB, Park SW, Kim H Bin, et al. Diagnostic value of direct fluorescence antibody staining for detecting Pneumocystis jirovecii in expectorated sputum from patients with HIV infection. Med Mycol. 2014;52(3):326-30. doi: 10.1093/mmy/myu002.

11. Procop GW, Haddad S, Quinn J, Wilson ML, Henshaw NG, Reller LB, et al. Detection of Pneumocystis jiroveci in respiratory specimens by four staining methods. J Clin Microbiol. 2004;42(7):3333-5. doi: 10.1128/JCM.42.7.3333-3335.2004

12. Tasaka S. Recent advances in the diagnosis and management of Pneumocystis pneumonia. Tuberc Respir Dis (Seoul). 2020;83(2):132-40. doi: 10.4046/trd.2020.0015

13. Guegan H, Robert-Gangneux F. Molecular diagnosis of Pneumocystis pneumonia in immunocompromised patients. Curr Opin Infect Dis. 2019;32(4):314-21. doi: 10.1097/0C0.0000000000000559

14. Chotiprasitsakul D, Pewloungsawat P, Setthaudom C, Santanirand P, Pornsuriyasak P. Performance of real-time PCR and immunofluorescence assay for diagnosis of Pneumocystis pneumonia in real-world clinical practice. PLoS One. 2021;15(12 December):1-12. doi: 10.1371/journal.pone.0244023

15. CDC. Guidelines for the Prevention and Treatment of Opportunistic Infections in Adults and Adolescents with HIV: Mycobacterium avium Complex Disease. 2019; Available at https://clinicalinfo.hiv. gov/sites/default/files/guidelines/documents/Adult_Ol.pdf

16. White P, Price J, Backx M. Therapy and Management of Pneumocystis jirovecii Infection. J Fungi. 2018;4(4):127. doi: 10.3390/ jof4040127.

17. Liu Y, Su L, Jiang SJ, Qu H. Risk factors for mortality from pneumocystis carinii pneumonia (PCP) in non-HIV patients: A metaanalysis. Oncotarget. 2017;8(35):59729-39. doi: 10.18632/oncotarget.19927 
Ana Isabel Peláez Ballesta ${ }^{1}$ Elisa Garcia Vázquez $z^{2,3}$ Joaquín Gómez Gómez

\title{
Infective endocarditis treated in a secondary hospital: epidemiological, clinical, microbiological characteristics and prognosis, with special reference to patients transferred to a third level hospital
}

\author{
IInternal Medicine Department of the Hospital General Universitario Rafael Méndez (Lorca) \\ ${ }^{2}$ Infectious Diseases Department. Hospital Clínico Universitario Virgen de la Arrixaca (Murcia). IMIB \\ ${ }^{3}$ Faculty of Medicine. Universidad de Murcia.
}

Article history

Received: 21 June 2021; Revision Requested: 8 September 2021; Revision Received: 7 October 2021; Accepted: 14 October 2021; Published: 30 November 2021

\section{ABSTRACT}

Introduction. To analyse the clinical and epidemiological characteristics and mortality-related factors of patients admitted to a secondary hospital with Infective Endocarditis (IE).

Methods. Observational study of a cohort of patients who have been diagnosed with IE in a secondary hospital and evaluated in accordance with a pre-established protocol.

Results. A total of 101 cases were evaluated (years 20002017), with an average age of 64 years and a male-to-female ratio of 2:1. 76\% of the cases had an age-adjusted Charlson comorbidity index of $>6$, with $21 \%$ having had a dental procedure and $36 \%$ with a history of heart valve disease. The most common microorganism was methicillin-susceptible $S$. aureus (36\%), with bacterial focus of unknown origin in 54\%. The diagnostic delay time was 12 days in patients who were transferred, compared to 8 days in patients who were not transferred ( $p=0.07)$; the median surgery indication delay time was 5 days (IOR 13.5). The in-hospital mortality rate was 34.6\% and the prognostic factors independently associated with mortality were: cerebrovascular events (OR 98.7\%, 95\% Cl, 70.9-164.4); heart failure $(\mathrm{OR} 27.3,95 \% \mathrm{Cl}, 10.2-149.1)$; and unsuitable antibiotic treatment (OR 7.2, 95\% Cl, 1.5-10.5). The mortality rate of the patients who were transferred and who therefore underwent surgery was 20\% (5/25).

Conclusions. The onset of cerebrovascular events, heart failure and unsuitable antibiotic treatment are independently and significantly associated with in-hospital mortality. The mortality rate was higher than the published average (35\%); the diagnostic delay was greater in patients for whom surgery was indicated.

Keywords: infective endocarditis, drug therapy, surgery

Correspondence:

Ana Isabel Peláez Ballesta

Internal Medicine Department of the Hospital General Universitario Rafael Méndez (Lorca) E-mail: anapelaezballesta@gmail.com
La endocarditis infecciosa en un hospital de $2^{\circ}$ nivel: epidemiologia, clínica y análisis de factores pronósticos, con especial referencia a los pacientes trasladados a un hospital de tercer nivel

\section{RESUMEN}

Introducción. Analizar las características clínico-epidemiológicas y los factores asociados a mortalidad de los pacientes ingresados por endocarditis infecciosa (El) en un Hospital de $2^{\circ}$ nivel.

Métodos. Estudio observacional de una cohorte de pacientes diagnosticados de El en un hospital de $2^{\circ}$ nivel y evaluados de acuerdo a un protocolo preestablecido.

Resultados. Se evaluaron 101 casos (2000-2017), edad media de 64 años, relación hombre/mujer 2:1, presentando un indice de Charlson corregido por edad $>6$ en el $76 \%$ de los casos, antecedentes de manipulaciones dentarias en el 21\% y valvulopatía previa en el 36\%. El microorganismo más frecuente fue Staphylococcus aureus sensible a meticilina (36\%), con foco bacteriémico de origen desconocido en el 54\%. El tiempo de demora diagnóstica fue de 12 dias en pacientes transferidos frente a 8 en los no transferidos ( $p=0.07)$; el de demora de indicación de cirugía tuvo una mediana de 5 dias (RIO 13.5). La mortalidad intrahospitalaria fue del $34.6 \%$ y los factores pronósticos asociados de forma independiente fueron la presencia de eventos vasculares cerebrales (OR 98.7, IC 95\% 70.9-164.4), el fallo cardiaco (OR 27.3, IC 95\% 10.2 - 149.1) y el tratamiento antibiótico inadecuado (OR 7.2, IC $95 \%$ 1.5-10.5). La mortalidad intrahospitalaria de los pacientes transferidos y por tanto intervenidos fue del 20\% (5/25).

Conclusiones. El desarrollo de eventos vasculares cerebrales, el fallo cardiaco y el tratamiento antibiótico inadecuado se asocian de forma independiente y significativa con mortalidad intrahospitalaria. La mortalidad fue superior a la media publicada (35\%); la demora diagnóstica fue mayor en los pacientes con indicación quirúrgica.

Palabras clave: endocarditis infecciosa, tratamiento, cirugía 


\section{INTRODUCTION}

Despite the improvement in diagnostic techniques and medical and surgical treatment protocols, infective endocarditis (IE) is associated with high morbidity and mortality related to the development of serious complications [1-5]. In general, the published series of IE patients refer to hospitals with more than 600 beds and referral surgical departments, including cardiovascular surgery. The characteristics of IE patients who are assessed in secondary hospitals with fewer than 300 beds and no cardiovascular surgery departments or interventional radiology units are probably different to patients who are assessed in general hospitals equipped with referral services in their area of geographical influence. It also has yet to be established whether assessments in regional hospitals without multidisciplinary IE teams and with less experience in a less prevalent disease than other infections may affect the diagnosis of $I E$, patient outcomes and the time to referral to specialist hospitals.

The objectives of this study were: to analyse the epidemiological, clinical and microbiological characteristics of a cohort of patients diagnosed with IE in a secondary hospital over a 17-year period (2000-2017); to analyse the prognostic factors associated with in-hospital mortality; to analyse the delay until diagnosis and referral to another hospital, if required; and to assess the degree of suitability of antibiotic therapy, so as to identify how the management of these patients in non-specialist hospitals can be improved.

\section{MATERIAL AND METHODS}

A retrospective, descriptive and observational study was conducted on adult patients who were diagnosed with IE between January 2000 and May 2014, and prospectively between May 2014 and December 2017.

Characteristics of the hospital. Hospital General Universitario Rafael Méndez de Lorca is a secondary hospital with 287 beds, with a catchment area of 175,154 inhabitants.

Patient study. During the study periods, all medical records of patients with the Diagnosis-related Group (DRG) of "Infective Endocarditis" at discharge were reviewed. All cases which did not comply with the diagnostic criteria of definite or possible IE were excluded [6-9].

For each patient, both the digital hospital discharge report corresponding to the clinical process and the digital and physical medical record (of previous admissions and admission due to the episode of IE) were reviewed. The microbiological information was supplemented with the hospital's laboratory records. The protocol of the Task Force for the Management of Infective Endocarditis of the Spanish Society of Cardiovascular Infections (GAME-SEICAV) study was used for data collection. Patients were classified according to comorbidity and prognosis of their underlying disease using the simple and age-adjusted Charlson comorbidity index [10].
The antibiotic therapy administered for IE was considered correct or incorrect according to current guidelines [7,11-12]. Empirical treatment was defined as treatment administered at the onset of symptoms, before blood culture results were available, and targeted treatment was defined as when empirical antibiotic therapy was modified according to the antibiogram results. Empirical and targeted treatment were considered adequate when an antibiotic was used (at the correct doses and intervals) to which the microorganism was sensitive in vitro, and whose indication was correct in terms of pharmacokinetics and pharmacodynamics for IE and in relation to the focus of infection that gave rise to the bacteraemia causing the development of IE. Those treatments that adhered to the therapeutic guidelines corresponding to cases of IE with negative blood cultures and serology were also considered appropriate. If this was not the case, the treatment was defined as unsuitable or incorrect.

Surgery indication delay time is defined as the time (in days) between the diagnosis of IE and the need for surgery being indicated. Surgery delay time is defined as the time (in days) between surgery being indicated by the heart surgeon and that surgery being performed.

Statistical analysis. The data were analysed using the statistical program SPSS18. For the descriptive analysis, the quantitative variables were expressed as mean/median (standard deviation, range), while qualitative variables were expressed as percentages. The link or relationship between pairs of qualitative variables was ascertained by conducting an analysis of the contingency tables using Pearson's chi-squared $\left(\mathrm{x}^{2}\right)$ test, completed with a residual analysis to determine the direction of dependence with Fisher's exact test. The means of the quantitative variables were compared with the Student's t-test. The difference was considered to be significant when $\mathrm{p}<0.05$ and the confidence intervals $(\mathrm{Cl})$ were set at 95\%. A bivariate analysis of the prognostic factors associated with in-hospital mortality was also conducted. A multivariate analysis of the significant factors and the non-significant factors that were considered clinically relevant for in-hospital mortality was conducted using the logistic regression method to determine the factors independently associated with mortality.

\section{RESULTS}

In total, 101 patients were assessed to ascertain whether they meet definite or possible IE criteria in accordance with the Modified Duke Infective Endocarditis Criteria, of which 68.3\% ( $n=69$ ) correspond to the retrospective period (2000-2013) and $31.7 \%(n=32)$ to the prospective period (2014-2017) with an increase in the number of cases in the prospective collection (Figure 1); with an average age of 64 years (range 16-88) and a male-to-female ratio of 2:1. The prevalence of IE amongst admitted patients was $0.057 \%$, with an incidence of 3 per 1000 patients per year.

There was a predominant involvement of native valves (82\%), with the mitral valve being the most commonly affect- 


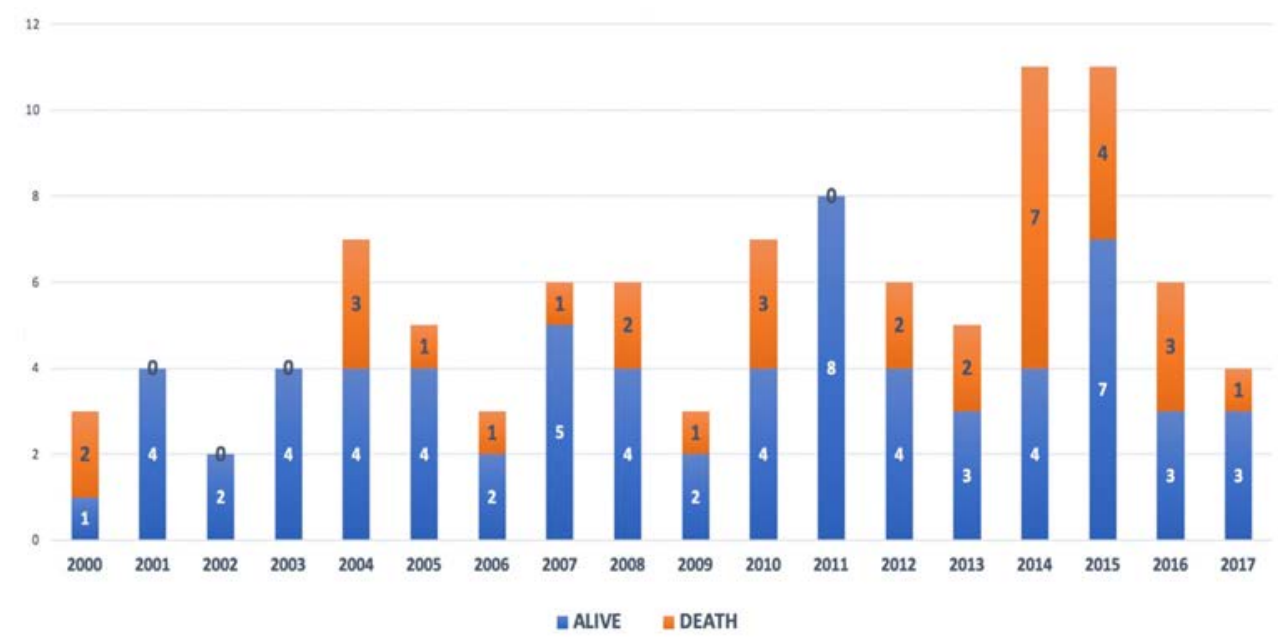

\begin{tabular}{l|l} 
Figure 1 & New cases by year and associated in-hospital mortality of IE.
\end{tabular}

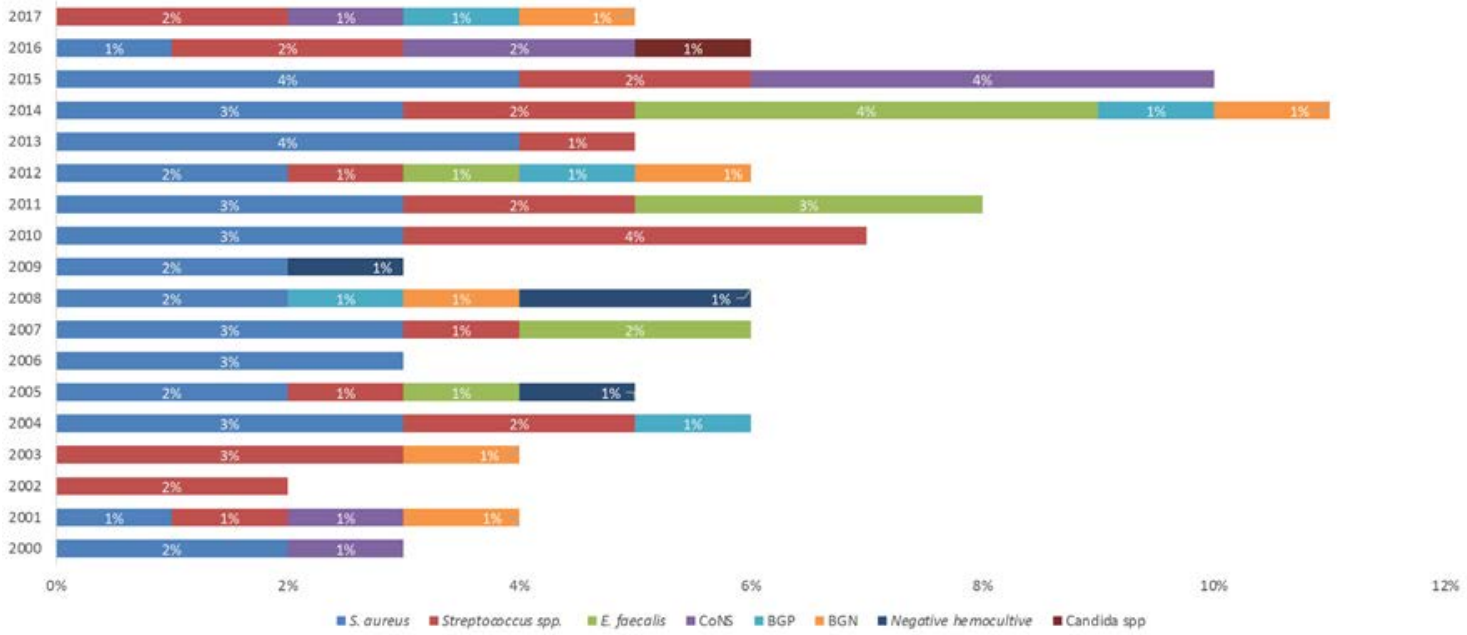

Figure 2 Evolution of microbiological data by years. Regarding S. aureus, there were 3 cases of methicillin-resistant $S$. aureus (one case in 2007, one case in 2012, and one case in 2013).

BGN: Gram-negative bacillus; BGP: Gram positive bacillus; CoNS: Coagulase-negative staphylococci.

ed (46.5\%). 76\% of patients had an age-adjusted Charlson comorbidity index of $>6$, with $31.6 \%$ having a Charlson comorbidity index of $>3$. Predisposing factors included previous valve disease (35.6\%, with degenerative valve disease in $20.8 \%$ of the cases). It should also be noted that $20 \%$ of cases had undergone a previous procedure that may explain the origin of the bacteraemia (insertion of catheters (9), dental procedures (5) and urinary procedures (3). No pre-procedure antibiotic prophylaxis was recorded in the medical records.

Blood cultures were taken from all patients, with positive results in 95 cases (94\%). Negative results were only recorded in five of the 12 patients who had received antibiotic therapy prior to the blood culture extraction (4.9\%). The source of the bacteraemia was not clarified in 54\% of the cases. Serology tests were only conducted on 10 patients (9.9\%), all yielding negative results. In no case were nucleic acid amplification molecular biology studies performed in blood or in dried valves for aetiological documentation.

The most commonly documented microorganisms in blood cultures were $S$. aureus (34.6\%; methicillin-susceptible S. aureus (MSSA) in 31.6\%); Streptococcus spp. (34\%); Coagulase-negative staphylococcus (CoNS, 12\%); and Enterococcus 


\begin{tabular}{|c|c|c|c|c|c|}
\hline $\begin{array}{l}\text { Analysis of th } \\
\text { not transferre }\end{array}$ & haracteristics & patients transf & ed to the refer & ce hos & ital versus \\
\hline Characteristic & $\begin{array}{c}\text { Transferred } \mathrm{N}=25 \\
\mathrm{~N}(\%)\end{array}$ & $\begin{array}{c}\text { Not transferred } \mathrm{N}=76 \\
\mathrm{~N}(\%)\end{array}$ & $\begin{array}{c}\text { Total } N=101 \\
\mathrm{~N}(\%)\end{array}$ & $p$ & OR (IC 95\%) \\
\hline \multicolumn{6}{|l|}{ EPIDEMIOLOGY } \\
\hline Age (median + / IQR; range) & $66+/-16(20-74)$ & $71+/-14(16-88)$ & $64.5+\mid-16(16-88)$ & 0.016 & \\
\hline Man & $18(72)$ & $51(67.1)$ & $69(68.3)$ & & \\
\hline Woman & $5(28)$ & $25(32.9)$ & $32(31.7)$ & 0.648 & $0.7(0.2-2.1)$ \\
\hline Death & $5(20)$ & $30(39.5)$ & $35(34.7)$ & 0.076 & $0.3(0.1-1.1)$ \\
\hline Sequelaes & $11(44)$ & $35(46.1)$ & $46(45.5)$ & 0.857 & $0.9(0.3-2.3)$ \\
\hline \multicolumn{6}{|l|}{ Valve affected } \\
\hline Native & $18(72)$ & $66(86.8)$ & $83(82)$ & 0.217 & \\
\hline Prosthetics & $6(24)$ & $9(11.8)$ & $15(14)$ & & \\
\hline Pacemaker / ICD & $1(4)$ & $1(1.3)$ & $2(2)$ & & \\
\hline \multicolumn{6}{|l|}{ Location } \\
\hline Mitral & $9(36)$ & $32(42.1)$ & $47(46.5)$ & & \\
\hline Aortic & $15(60)$ & $32(42.1)$ & $41(40.5)$ & & \\
\hline Tricuspid & 0 & $8(10.5)$ & $8(7.9)$ & 0.217 & \\
\hline Pulmonary & 0 & $3(3.9)$ & $3(3)$ & & \\
\hline Pacemaker / ICD Cable & $1(4)$ & $1(1.3)$ & $2(2)$ & & \\
\hline \multicolumn{6}{|l|}{ COMORBIDITIES } \\
\hline Coronary heart disease & $5(20)$ & $20(26.7)$ & $25(24.8)$ & 0.526 & $0.7(0.2-2.1)$ \\
\hline Atrial fibrillation & $3(12)$ & $17(22.4)$ & $20(19.8)$ & 0.259 & $0.5(0.1-1.8)$ \\
\hline Heart failure & $11(44)$ & $19(25)$ & $30(29.7)$ & 0.710 & $2.3(0.9-6.1)$ \\
\hline Diabetes Mellitus & $4(16)$ & $26(34.2)$ & $30(29.7)$ & 0.084 & $0.4(0.1-1.1)$ \\
\hline Peripheral vascular disease & $2(8)$ & $21(27.6)$ & $23(22.8)$ & 0.042 & $0.8(0.6-0.9)$ \\
\hline Cerebrovascular disease & $1(4)$ & $8(10.5)$ & $9(8.9)$ & 0.320 & $0.3(0.1-2.9)$ \\
\hline Neoplasia & $1(4)$ & $14(18.4)$ & $15(14.8)$ & 0.079 & $0.2(0.1-1.5)$ \\
\hline Renal insufficiency & $2(8)$ & $13(17.1)$ & $15(14.8)$ & 0.416 & \\
\hline Charlson comorbidity index $\geq 3$ & $6(24)$ & $26(34.2)$ & $32(31.6)$ & 0.740 & $3.2(0.1-2.3)$ \\
\hline $\begin{array}{l}\text { Charlson comorbidity index adjusted for } \\
\text { age } \geq 6\end{array}$ & $19(76)$ & $58(76.3)$ & $77(76.2)$ & 0.064 & $2.1(0.1-2.5)$ \\
\hline SYMPTOMS & & & & & \\
\hline Fever & $25(100)$ & $76(100)$ & $101(100)$ & 0.991 & $1.1(0.1-10.2)$ \\
\hline Vascular phenomena & $5(20)$ & $4(5.3)$ & $9(8.9)$ & 0.025 & $4.5(1.1-18.3)$ \\
\hline Embolisms & $6(24)$ & $23(30.3)$ & $29(28.9)$ & 0.548 & $0.7(0.2-2.1)$ \\
\hline Diagnostic delay time (median +/- IQR) & $11.92+/-11.5$ & $8.32+/-8.52$ & $8+/ 13.5$ & 0.075 & \\
\hline MICROBIOLOGY & & & & & \\
\hline Streptococcus spp. & $5(20)$ & $22(28.9)$ & $27(26.7)$ & & \\
\hline Staphylococcus aureus & $14(56)$ & $21(27.6)$ & $35(34.6)$ & & \\
\hline MRSA & $2(8)$ & $1(1.3)$ & $3(2.9)$ & & \\
\hline Coagulase-negative staphylococci (CoNS) & $5(20)$ & $17(22.3)$ & $12(11.8)$ & & \\
\hline Enterococcus spp. & $0(0)$ & $11(14.4)$ & $11(10.8)$ & $0.088^{\mathrm{a}}$ & \\
\hline Gram-negative bacilli & $3(12)$ & $2(2.6)$ & $5(4.9)$ & & \\
\hline Gram-positive bacilli & $0(0)$ & $5(6.5)$ & $5(4.9)$ & & \\
\hline Candida spp. & $0(0)$ & $1(1.3)$ & $1(0.9)$ & & \\
\hline TREATMENT & & & & & \\
\hline Inappropriate treatment & $5(20)$ & $14(18.4)$ & $19(19)$ & 0.861 & $0.9(0-2-2.8)$ \\
\hline
\end{tabular}

ICD: implanted cardioverter defibrillator; IQR: interquartile range; MRSA: Methicillin resistant Staphylococcus aureus.

aAll microorganisms were included in the analysis. 


\begin{tabular}{l|ccc}
\hline Table 2 & $\begin{array}{l}\text { Bivariate analysis according to treatment } \\
\text { regimen. }\end{array}$ \\
\hline Characteristic & $\begin{array}{c}\text { Inadequate treatment } \\
\mathrm{N}=19 \\
\mathrm{n}(\%)\end{array}$ & $\begin{array}{c}\text { Appropriate treatment } \\
\mathrm{N}=82 \\
\mathrm{n}(\%)\end{array}$ & $\mathrm{p}$ \\
\hline "NEW" heart failure & $19(100)$ & $57(69.5)$ & 0,006 \\
\hline Persistent bacteremia & $17(36.8)$ & $8(9.8)$ & 0.003 \\
\hline Mechanic ventilation & $10(52.6)$ & $13(15.9)$ & 0.001 \\
\hline Vasoactive drugs & $13(68.4)$ & $24(29.3)$ & 0.001 \\
\hline Septic shock & $13(68.4)$ & $34(41.5)$ & 0.034 \\
\hline Spread of infection & $4(21.1)$ & $4(4.9)$ & 0.019 \\
CCV indication & $10(52.6)$ & $25(30.5)$ & 0.048 \\
\hline Death & $12(63.2)$ & $21(25.6)$ & 0.002 \\
\hline
\end{tabular}

CCV: Cardiovascular surgery.

Table 3 Multivariate analysis of factors independently associated with mortality.

\begin{tabular}{lcc}
\hline Characteristic & $p$ & $0 \operatorname{Ra~(Cl~95\% )~}$ \\
\hline CNS vascular event & 0.033 & $98.7(70.9-164.4)$ \\
New onset heart failure & 0.003 & $27.3(10.2-149.1)$ \\
Inadequate antibiotic treatment & 0.003 & $7.2(1.5-10.5)$ \\
\hline
\end{tabular}

CNS: Central nervous system.

spp. (11\%, all ampicillin-susceptible Enterococcus). The distribution by year is shown in Figure 2 .

The most commonly observed clinical manifestations were fever (100\%), heart failure (75\%) and recent murmur (64\%). Vascular phenomena suggestive of endocarditis were observed in just nine (8.9\%) of the patients during the examination. These included petechiae $(n=7 ; 6.9 \%)$, Janeway lesions $(n=6$; $5.9 \%)$, splinter haemorrhages $(n=3 ; 2.9 \%)$ and conjunctival haemorrhages $(n=2 ; 1.9 \%)$, with no findings of Osler's nodes or Roth's spots recorded in any of the patients.

A transthoracic echocardiogram (TE) was performed in 100 (99\%) of the patients (a transoesophageal echocardiogram [TOE] was performed first in just one of the patients), which was positive for IE in 62 patients (62.6\%). In the 38 patients with negative TE, the diagnosis was made following TOE.

A 66\% of the patients developed a complication, primarily embolic processes of the central nervous system (16.7\%) and the spleen (7\%).

Surgery was indicated for $34.6 \%$ of the patients $(n=35)$. However, only 28 were assessed by the Heart Surgery Department (the rest were not assessed due to poor prognosis, advanced age and/or refusal of the patient or the family to undergo surgery). Ultimately, 25 patients underwent surgery (the other three patients were rejected for surgery). Table 1 summarises the characteristics of the cohort of patients who were transferred to a specialist surgical centre and those who were not. Only patients indicated for surgery were transferred. Insofar as the surgery indication delay time is concerned, the median time was five days (interquartile range [IQR] 13.5). The median surgery delay time was three days (IQR 10).

Regarding the treatment regimen, it was observed that the onset of complications such as heart failure, septic shock and the spread of infection, maintained bacteraemia, the need for mechanical ventilation and vasoactive drugs, the indication for heart surgery and mortality were more common and statistically significant in the group of patients receiving unsuitable treatment (Table 2).

The in-hospital mortality rate was $34.7 \%$, with the onset of acute vascular processes of the central nervous system (OR 98.7, 95\% Cl, 70.9-164.4), heart failure (OR 27.3, 95\% Cl, 10.2-149.1) and receiving unsuitable treatment (OR 7.2, 95\% $\mathrm{Cl}, 1.5-10.5)$ being prognostic factors independently associated with mortality (Table 3 ). It is striking that the mortality rate of the group of patients for whom surgery was indicated, but who did not end up undergoing surgery, was 60\% (6/10), while the mortality rate for those who did end up receiving surgery, and who were therefore transferred, was 20\% (5/25) $(p<0.001)$. The in-hospital mortality rate of the group of patients for whom surgery was not indicated was $36 \%$, similar to that of the overall cohort (Figure 3).

\section{DISCUSSION}

The most relevant epidemiological characteristics of this group of patients were: the incidence of 2-4 cases per year; an average age of 64 years; the male-to-female ratio of 2:1; the age-adjusted Charlson comorbidity index of $>6$ in $76 \%$; the history of dental procedures (21\%); previous valve disease (36\%); the isolation in blood of MSSA (36\%) as the most common microorganism; and the absence of a focus of origin in 54\% of the patients. In total, $88 \%$ of the patients met the criteria for definite infective endocarditis. These results are similar to those found in other studies $[1,4,13-16]$, with the high mortality rate (35\%)-which was lower in patients who had been transferred for surgery (20\%)-being particularly noteworthy.

Our study may suffer from several limitations: it is a partially retrospective cohort, meaning information could be missing in the medical records; it covers a broad period of time (2000 to 2017), during which structural and organisational changes may have taken place in our hospital, introducing variables that we weren't able to detect owing to the size of the sample; and not having conducted a peer review of the cases, which could have led to biases when assessing the suitability of antibiotic therapy. Finally, although we used the guidelines and protocols that are accepted in the medical literature, some of the recommendations have a low level of evidence, or the opinions of experts regarding said recommendations may vary. 


\section{Post-surgical evolution}

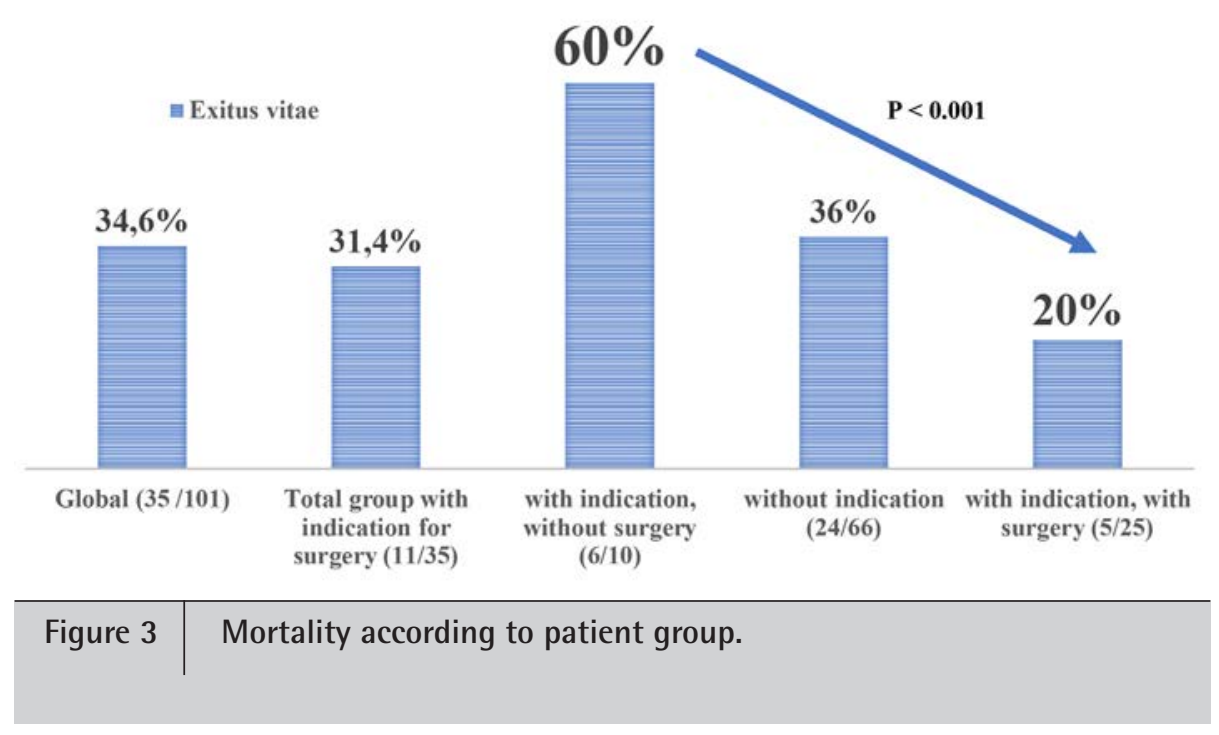

In relation to aetiology, several series in the literature show that there has been an evolutionary change $[4,7,13-$ $14,16-17]$. Our findings show that MSSA is the most common (34\%), followed by CoNS (11.8\%), while the prevalence of methicillin-resistant S. aureus (MRSA) is extremely low (3/35; $2.9 \%$ ). In the cases of IE owing to Streptococcus spp. (24\%) and E. faecalis (11\%), unlike other studies, no correlation was found with neoplastic gastrointestinal diseases, probably owing to the lack of suitable gastrointestinal studies [4,18-21]. The aetiology by Gram-negative bacilli was found to be $4.7 \%$, similar to that reported by other investigators $[4,13-14,16-$ 17,22-23].

In-hospital mortality in our series was $34.6 \%$, with independently associated prognostic factors including cerebrovascular events, refractory heart failure and unsuitable antibiotic therapy. The mortality rate described in the literature $[2,5,13-$ 16 ] is generally below $30 \%$. It should be noted that, in our cohort, the in-hospital mortality rate of patients who were transferred to the regional referral hospital for heart surgery was lower at 20\%, which is more in line with the rate published by other authors. In this regard, in a study of a cohort of IE patients in a secondary hospital, López Dupla et al. [15] found that after the introduction of protocols and the launching of a multi-disciplinary team, the intra-hospital mortality rate decreased from $21 \%$ to $14 \%$.

A multi-centre study conducted by the ICE (International Collaboration on Endocarditis) [24] compared its cohort of transferred patients with the non-transferred patients and identified the presence of complications as factors associated with transfer. Despite this, the mortality rates were simi$\operatorname{lar}(17 \%$ vs 18\%), and they concluded that the most severe patients would be transferred, thus introducing a bias in the comparisons. The study did not analyse the variable of suitable or unsuitable antibiotic therapy or the variable of surgery. In another 2011 cohort [1], a sub-group of patients in Barcelona who were transferred to a referral centre were analysed, and it was again observed that they exhibited more complications than the rest of the cohort. Logically, this is also a sub-group that undergoes heart surgery with greater frequency $169 \%$ vs $22 \%$ ), as this is probably the reason why they were transferred. However, they had a lower mortality rate (23\% vs 31\%, although this was not deemed to be statistically significant). The authors highlighted that only $45 \%$ of the transferred patients received suitable antibiotic therapy, compared to $100 \%$ of patients who were treated in the referral hospital from the very beginning. Receiving unsuitable treatment during transfer was a risk factor (OR $3.3 ; 95 \% \mathrm{Cl}, 1.1-10)$ for death, although the multivariate analysis of risk factors for mortality was not provided.

Other authors have analysed cohorts of patients treated in hospitals without heart surgery facilities, highlighting cohorts with a lower mortality rate than that which is usually published (19\%). They also found that the creation of a multidisciplinary working group and the implementation of protocols reduces this figure even further (8-14\%) [11,25-29]. A more recent cohort suggests that patients treated in secondary centres may be older and have more comorbidities [30]. In 2014, a national study [31] compared two tertiary hospitals, with and without heart surgery facilities, and detected mortality rates of $18 \%$ vs $32 \%$. However, in the multivariate analysis, only the variables of age and onset of complications, as well as the need for emergency surgery, were associated with deathnot whether the patient was treated at one hospital or another (despite statistically significant differences in the surgery delay time). It is worth noting, however, that the variable of unsuitable antibiotic therapy was not analysed. In our experience, the development of complications, unsuitable antibiotic therapy and the severity of the diagnosis are risk factors of mortality. 
However, being treated in a secondary hospital is not necessarily a risk factor.

There is currently a lack of data to establish definitive recommendations regarding the question of whether or not IE patients should be transferred to a referral hospital, but it is very likely that a lack of a protocol, a lack of multidisciplinary teams and a higher prevalence of unsuitable antibiotic therapy are variables associated with a poorer prognosis for IE patients. Some studies indicate that these characteristics may be more prevalent in secondary hospitals, where a delay in referral to specialist hospitals may further increase the mortality rate. In view of this, it is essential to implement agreed protocols adapted to the characteristics of each hospital and to draw up user-friendly guidelines, benefitting from the services of at least one clinical consultant specialising in infectious diseases in secondary hospitals. The active participation of the infectious disease consultant has been associated with better outcomes in patients with bacteraemia and endocarditis, specified in various guidelines as being an alternative-almost mandatory-in the diagnostic and therapeutic assessment and during the monitoring of these patients [11,25-29,32]. Unsuitable antibiotic therapy is a particularly relevant factor, as it can be modified. In our analysis, and consistent with Fayad et al. [33], it was independently associated with a mortality rate that was seven times higher (OR 7.2). This section probably emerges as one of the areas of improvement with the greatest clinical impact, due to its potential positive influence on the outcomes of these patients.

Infective endocarditis is a complex infectious disease that is difficult to manage, which is why the existence of a multidisciplinary medical and surgical team that specialises in these processes would optimise its treatment and could lead to reduced morbidity and mortality.

\section{FUNDING}

None to declare

\section{CONFLICTS OF INTEREST}

The authors declare no conflict of interest

\section{REFERENCES}

1. Fernández-Hidalgo N, Almirante B, Tornos P, Gonzalez M, Planes A, Larrosa $\mathrm{M}$ et al. Prognosis of left-sided infective endocarditis in patients transferred to a tertiary-care hospital-prospective analysis of referral bias and influence of inadequate antimicrobial treatment. Clin Microbiol Infect. 2011;17(5):769-775. doi: 10.1111/j.14690691.2010.03314.x

2. El-Dalati S, Cronin D, Shea M, Weinberg R, Riddell J 4th, Washer $L$, et al. Clinical Practice Update on Infectious Endocarditis. Am J Med. 2020 Jan;133(1):44-49. doi: 10.1016/j.amjmed.2019.08.022.

3. Cuervo G, Escrihuela-Vidal F, Gudiol C, Carratalà J. Current Challeng- es in the Management of Infective Endocarditis. Front Med (Lausanne). 2021 Feb 22;8:641243. doi: 10.3389/fmed.2021.641243.

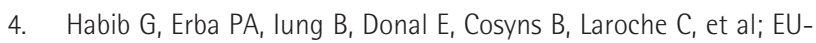
RO-ENDO Investigators. Clinical presentation, aetiology and outcome of infective endocarditis. Results of the ESC-EORP EURO-ENDO (European infective endocarditis) registry: a prospective cohort study. Eur Heart J. 2019 Oct 14;40(39):3222-3232. doi: 10.1093/ eurheartj/ehz620.

5. Lazaros $G$, Lazarou $E_{1}$ Tousoulis D. Predicting mortality in infective endocarditis: More light in a hazy landscape. Hellenic J Cardiol. 2020 Jul-Aug;61(4):253-255. doi: 10.1016/j.hjc.2020.09.013.

6. Ministerio de Sanidad, Política Social e Igualdad. CIE 9 MC. Manual de codificación. Información y estadisticas sanitarias 2011. Available from: www.mscbs.gob.es/estadEstudios/estadisticas/normalizacion/clasifEnferm/boletines/home.htm.

7. Habib G, Lancellotti P, Antunes MJ, Bongiorni MG, Casalta JP, Del Zotti F, et al. 2015 ESC guidelines for the management of infective endocarditis. EurHeart J.2015;36:3075-3128. DOI: 10.1093/ eurheartj/ehv319

8. Aguado JM, Almirante B, Fortún J et al. Tratamiento de la endocarditis infecciosa. Protocolos clínicos en enfermedades infecciosas. Pag 191-209.

9. Serrano-Herranz R, Barberan López J. Protocolos Enfermedades Infecciosas. 2 Edición. 2007;3:63-80.

10. Charlson ME, Pompei P, Ales KL, Mackenzie CR. A new method of classifying prognostic comorbidity in longitudinal studies: development and validation. J Chronic Dis 1987; 40:373-383. DOI: 10.1016/0021-9681(87)90171-8

11. Baddour LM, Wilson WR, Bayer AS, Fowler VG, Tleyjeh IM, Rybak MJ et al. American Heart Association Committee on Rheumatic Fever, Endocarditis, and Kawasaki Disease of the Council on Cardiovascular Disease in the Young, Council on Clinical Cardiology, Council on Cardiovascular Surgery and Anesthesia, and Stroke Council Infective Endocarditis in Adults: Diagnosis, Antimicrobial Therapy, and Management of Complications: A Scientific Statement for Healthcare Professionals From the American Heart Association. Circulation. 2015;132:1435-1486. doi:10.1161/CIR.0000000000000296

12. Mensa J, Gatell j, García-Sánchez JE, Letang E, López-Suñe, Marco F. Guía terapéutica antimicrobiana 2017; 602-608, 779.

13. Fernandez Hidalgo $N$, Almirante $B$, Tornos P, Pigrau C, Sambola A, Igual $A$ et al. Contemporary epidemiology and prognosis of health care-associated infective endocarditis. Clin Infect Dis. 2008; 47(10): 1287-1297. doi: 10.1086/592576

14. Slipczuk I, Codolosa JN, Davila CD, Romero A, Yun J, Pressman G et al. Infective endocarditis epidemiology over five decades: A systematic review. PloS One. 2013; 8 (12): e82665. doi: 10.1371/journal. pone.0082665

15. López-Dupla M, Hernández $\mathrm{S}$, Olona M, Mercé J, Lorenzo A, Tapiol $J$ et al. Clinical characteristics and outcome of infective endocarditis in individuals of the general population managed at a teaching hospital without cardiac surgery facilities. Study of 120 cases. Rev Esp Cardiol 2006;59(11):1131-1139. PMID: 17144988

16. Muñoz P, Kestler M, De Alarcon A, Miro JM, Bermejo J, Rodri- 
guez-Abella $\mathrm{H}$ et al. Current Epidemiology and Outcome of Infective Endocarditis: A Multicenter, Prospective, cohort study. Medicine (Baltimore). 2015; 94 (43): 1816. doi: 10.1097/MD.0000000000001816

17. Kalokhe AS, Rouphael N, El Chami MF, Workovski K, Ganesh G, Jacob J. Aspergillus endocarditis: a review of the literature. Int J Infect Dis. 2010;14:1040-1047.

18. Gómez-Garcésa JL, Gil Y, Burillo A, Wilhelmi I, Palomo M. Cuadros clínicos asociados a bacteriemia causada por las nuevas especies incluidas en el antiguo grupo Streptococcus bovis. Enferm Infecc Microbiol Clin. 2012;30(4):175-179. doi:10.1016/j.eimc.2011.09.015

19. Hensler M. Streptococcus gallolyticus, Infective Endocarditis, and Colon Carcinoma: New Light on an Intriguing Coincidence. J Infec Dis. 2011;203:1040-1042. doi: 10.1093/infdis/jiq170

20. Abdulamir AS, Hafidh R, Abu Bakar F. The association of Streptococcus bovis/gallolyticus with colorectal tumors: The nature and the underlying mechanisms of its etiological role. J Exp Clin Cancer Res. 2011; 30:11. doi: 10.1186/1756-9966-30-11

21. Galdy S, Nastasi G. Streptococcus bovis endocarditis and colon cancer: myth or reality? A case report and literature review. BMJ Case Rep 2012;2012:bcr2012006961. doi: 10.1136/bcr-2012-006961

22. Morpeth $S$, Murdoch D, Cabell C, Karchmer A, Pappas P, Levine D et al. Non-HACEK Gram-Negative Bacillus Endocarditis. Annals of Internal Medicine 2007;147:829-835. doi: 10.7326/0003-4819147-12-200712180-00002

23. Chambers ST, Murdoch D, Morris A, Holland D, Pappas P, Almela M et al. International Collaboration on Endocarditis Prospective Cohort Study Investigators. HACEK infective endocarditis: characteristics and outcomes from a large, multi-national cohort. Plos One. 2013;8:0063181. doi: 10.1371/journal.pone.0063181

24. Zupanc T, Kanj S, Cabell C, Cecchi E, Oliveiera A, Lejko T et al. Revisiting the effect of referral bias on the clinical spectrum of infective endocarditis in adults. Eur J Clin Microbiol Infect. 2010;29:12031210. doi: 10.1007/s10096-010-0983-2

25. Botelho-Never S, Thuny F, Casalta JP, Richet E, Gouriet F, Collart $F$ et al. Dramatic reduction in infective endocarditis-related mortality with a management-based approach. Arch Intern Med. 2009;169:1290-1298. doi: 10.1001/archinternmed.2009.192

26. Van Camp G, Beles M, Penicka M, Schelfaut D, Wouters S, De Raedt

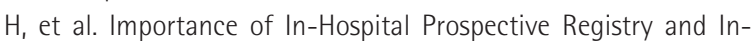
fectious Endocarditis Heart Team to Monitor and Improve Quality of Care in Patients with Infectious Endocarditis. J Clin Med. 2021;10(17):3832. doi: 10.3390/jcm 10173832.

27. Davierwala PM, Marin-Cuartas M, Misfeld M, Borger MA. The value of an "Endocarditis Team". Ann Cardiothorac Surg. 2019 Nov;8(6):621-629. doi: 10.21037/acs.2019.09.03.

28. Miro JM, Ambrosioni J. Infective endocarditis: an ongoing global challenge. Eur Heart J. 2019 Oct 14;40(39):3233-3236. doi: 10.1093/eurheartj/ehz694.

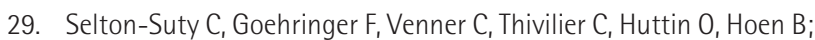
membres de l'Endocarditis Team du CHU de Nancy. Complications et pronostic de l'endocardite infectieuse [Complications and prognosis of infective endocarditis]. Presse Med. 2019 May;48(5):532538. doi: 10.1016/j.lpm.2019.04.002.
30. Poesen $K$, Pottel $H_{1}$ Colaert J, De Niel C. Epidemiology of infective endocarditis in a large Belgian non-referral hospital. Acta Clin Belg. 2014;69:183-190. doi: 10.1179/0001551214Z.00000000046

31. Rodríguez-Esteban M, Anguita M, Miranda-Montero S, Castillo JC, Alvarez-Acosta L, Castillo F et al. Endocarditis infecciosa en 2 hospitales universitarios españoles que difieren en su localización y en la presencia de servicio quirúrgico. Enferm Infecc Microbiol Clin. 2014;32:297-301. doi: 10.1016/j.eimc.2013.04.019

32. Hernández Contreras M.E, Hernández Torres A, Gómez Gómez J, García Vázquez E. Influencia en la evolución de los pacientes con bacteriemia/candidemia de la participación activa del especialista clínico en Patología Infecciosa. Estudio de una cohorte prospectiva. Infectio. 2017; 21 (1):32-38. doi: 10.22354/in.v21i1.639

33. Fayad G, Leroy G, Devos P, Hervieux E, Senneville E, Koussa M et al. Characteristics and prognosis of patients requiring valve surgery during active infective endocarditis. J Heart Valve Dis. 2011;20:223228. PMID: 21560826

34. Fernández-Hidalgo $N$, Almirante $B$, Tornos $P$, Gonzalez MT, Planes $A$, Galiñanes $M$ et al. Immediate and long-term outcome of left-sided infective endocarditis. A 12-year prospective study from a contemporary cohort in a referral hospital. Clin Microbiol Infect. 2012;18:E522-530. doi: 10.1111/1469-0691.12033

35. San Roman JA, Lopez J, Revilla A, Vilacosta I, Tornos P, Almirante $B$ et al. Rationale, design, and methods for the early surgery in infective endocarditis study (ENDOVAL 1): a multicenter, prospective, randomized trial comparing the state-of-the-art therapeutic strategy versus early surgery strategy in infective endocarditis. Am Heart J. 2008;156(3):431-436. doi: 10.1016/j.ahj.2008.04.006 
Rosa Méndez ${ }^{1}$

Angels Figuerola ${ }^{2}$

Marta Chicot $^{3}$

Ana Barrios ${ }^{4}$

Natalia Pascual ${ }^{5}$

Fernando Ramasco ${ }^{6}$

Diego Rodríguez ${ }^{3}$

İ̃̃igo García ${ }^{7}$

Andrés von Wernitz ${ }^{8}$

Nelly Zurita ${ }^{9}$

Auxiliadora Semiglia ${ }^{9}$

David Jiménez ${ }^{10}$

Sara Navarro ${ }^{10}$

María José Rubio ${ }^{11}$

Mercedes Vinuesa ${ }^{12}$

Lourdes del $\mathrm{Campo}^{13}$

Azucena Bautista ${ }^{4}$

Alberto Pizarro ${ }^{8}$

\section{Código Sepsis: esquivando la mortalidad en un hospital terciario}

\author{
${ }^{1}$ Servicio de Anestesia y Reanimación. Hospital Universitario de La Princesa, Madrid \\ ${ }^{2}$ Servicio de Medicina Preventiva. Hospital Universitario de La Princesa, Madrid \\ ${ }^{3}$ Servicio de Medicina Intensiva. Hospital Universitario de La Princesa, Madrid \\ ${ }^{4}$ Servicio de Medicina Interna. Sección de Enfermedades Infecciosas. Hospital Universitario de La Princesa, Madrid \\ ${ }^{5}$ Servicio de Laboratorio y Análisis Clínicos. Hospital Universitario de La Princesa, Madrid \\ ${ }^{6}$ Servicio de Anestesiología y Reanimación. Hospital Universitario de La Princesa, Madrid \\ ${ }^{7}$ Servicio de Cirugía General. Hospital Universitario de La Princesa, Madrid \\ ${ }^{8}$ Servicio de Urgencias. Hospital Universitario de La Princesa, Madrid \\ ${ }^{9}$ Servicio de Microbiología. Hospital Universitario de La Princesa, Madrid \\ ${ }^{10}$ Enfermería Código Sepsis. Hospital Universitario de La Princesa, Madrid \\ ${ }^{11}$ Supervisora de Área Funcional. Hospital Universitario de La Princesa, Madrid \\ ${ }^{12}$ Coordinadora de Calidad. Hospital Universitario de La Princesa, Madrid \\ ${ }^{13}$ Servicio de Radiología. Hospital Universitario de La Princesa, Madrid
}

\section{Article history}

Received: 17 July 2021; Revision Requested: 21 August 2021; Revision Received: 24 August 2021; Accepted: 2 September 2021; Published: 23 November 2021

\section{RESUMEN}

Introducción. En el hospital de La Princesa comienza el "Código Sepsis" (CSP) en el año 2015, como un grupo multidisciplinar que dota al personal sanitario de herramientas clinicas, analiticas y organizativas, con el objetivo de la detección y el tratamiento precoz del paciente con sepsis. El objetivo de este estudio es evaluar el impacto de la implantación de CSP en la mortalidad y determinar las variables asociadas con un aumento de la misma.

Material y métodos. Se realizó un estudio analítico retrospectivo de los pacientes con activación de la alerta CSP de 2015 a 2018. Se recogieron variables clinico-epidemiológicas, parámetros analiticos y factores de gravedad como el ingreso en Unidades de Cuidados Críticos (UCC) y la necesidad de aminas. La significación estadistica se estableció en una $p<0,05$.

Resultados. Se incluyeron 1.121 pacientes. La estancia media fue de 16 dias y un 32\% requirieron ingreso en UCC. La mortalidad mostró una tendencia lineal descendente estadisticamente significativa del 24\% en 2015 hasta el 15\% en 2018. Las variables predictivas de mortalidad con asociación estadisticamente significativa fueron el lactato $>2 \mathrm{mmol} / \mathrm{L}$, la creatinina $>1,6 \mathrm{mg} / \mathrm{dL}$ y la necesidad de aminas.

Conclusiones. La implementación de Código Sepsis disminuye la mortalidad de los pacientes con sepsis y shock séptico. La presencia de una cifra de lactato $>2 \mathrm{mmol} / \mathrm{L}$, los niveles de creatinina $>$ $1,6 \mathrm{mg} / \mathrm{dL}$ y/o la necesidad de administrar aminas en las primeras 24 horas, se asocian con un aumento de la mortalidad en el paciente con sepsis.

Palabras clave: Código Sepsis; mortalidad; lactato; creatinina; aminas

Correspondencia:

Rosa Méndez Hernández.

Servicio de Anestesia y Reanimación. Hospital Universitario de La Princesa. Calle Diego de

León 62. 28006. Madrid

E-mail: rosamen2004@hotmail.com

\section{Sepsis Code: dodging mortality in a tertiary hospital}

\section{ABSTRACT}

Background. In the hospital of La Princesa, the "Sepsis Code" (CSP) began in 2015, as a multidisciplinary group that provides health personnel with clinical, analytical and organizational tools, with the aim of the detection and early treatment of patients with sepsis. The objective of this study is to evaluate the impact of CSP implantation on mortality and to determine the variables associated with an increase in it.

Material and methods. A retrospective analytical study of patients with CSP alert activation from 2015 to 2018 was conducted. Clinical-epidemiological variables, analytical parameters, and severity factors such as admission to critical care units (UCC) and the need for amines were collected. Statistical significance was established at $p<0.05$.

Results. We included 1,121 patients. The length of stay was 16 days and 32\% required admission to UCC. Mortality showed a statistically significant linear downward trend from $24 \%$ in 2015 to $15 \%$ in 2018. The predictive mortality variables with statistically significant association were lactate $>2$ $\mathrm{mmol} / \mathrm{L}$, creatinine $>1.6 \mathrm{mg} / \mathrm{dL}$ and the need for amines.

Conclusions. The implementation of Sepsis Code decreases the mortality of patients with sepsis and septic shock. The presence of a lactate $>2 \mathrm{mmol} / \mathrm{L}$, creatinine $>1.6 \mathrm{mg} / \mathrm{dL}$ and/or the need to administer amines in the first 24 hours, are associated with an increase in mortality in the patient with sepsis.

Keywords: sepsis code, mortality, lactate, creatinine, amines 


\section{INTRODUCCIÓN}

La sepsis es una disfunción orgánica que amenaza la vida, y se produce por la respuesta aberrante del huésped a la infección [1]. Es una patología tiempo dependiente, influyendo en su pronóstico la rapidez con que se realice el diagnóstico de sospecha y se inicien las medidas adecuadas de tratamiento.

En el año 2004 se publicaron las primeras guias de la Campaña de Sobrevivir a la Sepsis (con actualizaciones cada 4 años, hasta las últimas publicadas en el año 2016 [2]), con la intención de unificar el tratamiento y mejorar los resultados, a pesar de lo cual, la mortalidad de los pacientes con sepsis se sitúa en torno al 10\%, aumentando hasta el 40\% en aquellos pacientes en los que se desarrolla un shock séptico [3-5].

A la luz de los excelentes resultados en morbilidad y mortalidad de otras patologías tiempo dependientes como son el ictus o el infarto de miocardio tras la implantación de modelos de "códigos de actuación", comienzan a aparecer grupos "Código Sepsis" (CS) a nivel local y comunitario como un conjunto de herramientas organizativas que facilitan la precocidad en la detección y la puesta en marcha de las recomendaciones de tratamiento [6-8], siendo todavía escaso el impacto publicado en la bibliografía sobre la mortalidad tras la instauración de un CS.

En el hospital universitario de La Princesa de Madrid comienza el "Código Sepsis Princesa" (CSP) en el año 2015, formado por un grupo multidisciplinar que se encarga de dotar de herramientas clínicas, organizativas y analiticas a todo el personal sanitario, las cuales tienen como objetivo detectar de manera precoz a estos pacientes, priorizando su atención y ajustando su tratamiento [9]. Mediante la activación de la alerta CSP en el sistema informático hospitalario, se priorizan las pruebas de imagen, la obtención de los parámetros incluidos en la escala SOFA (Sequential Organ Failure Assessment Score), biomarcadores como procalcitonina y/o lactato, así como la identificación del microorganismo causal y su antibiograma mediante técnicas de detección rápida disponibles en el hospital. Asimismo, los pacientes activados tienen prioridad para ser valorados por las Unidades de Cuidados Críticos (UCC) médicas o quirúrgicas y para recibir tratamiento de control del foco infeccioso de manera invasiva mediante cirugía o radiología intervencionista.

Los miembros del grupo CSP también llevan a cabo cursos intensivos de formación y actualización continua para el personal médico y de enfermería y promueven el uso de ayudas cognitivas para poder optimizar el tratamiento de estos pacientes.

El objetivo de este estudio es evaluar el impacto de la implantación de CSP en la mortalidad de los pacientes con sepsis así como determinar las variables asociadas con un aumento de la mortalidad.

\section{MATERIAL Y MÉTODOS}

Para evaluar el proyecto CSP se realizó un estudio ana- lítico observacional retrospectivo de todos los pacientes con activación de la alerta CSP entre el 1 de enero de 2015 y el 31 de diciembre de 2018. El reclutamiento de los pacientes fue consecutivo según la fecha de la alerta activada.

Se recogieron variables clínico-epidemiológicas: edad, sexo, tensión arterial sistólica, frecuencia cardiaca, frecuencia respiratoria, Saturación de oxígeno y temperatura en el momento de la activación de CSP; parámetros analíticos: Iactato, procalcitonina y creatinina basales, a las 6-12 horas y a las 1224 horas tras el inicio de la sepsis y factores de gravedad como el ingreso en UCC y la escala SOFA.

Respecto a la antibioterapia y medidas de soporte, se registraron todos los antibióticos que recibió el paciente en las primeras 6 horas tras la activación del CSP y las aminas administradas en las primeras 24 horas.

Como variables de resultado se calcularon la mortalidad, la estancia hospitalaria y la estancia en UCC.

Para el análisis descriptivo de las variables cualitativas se determinó frecuencia y porcentaje, utilizando el test de la ${ }^{2} 0$ la prueba no paramétrica exacta de Fisher para su comparación.

En las variables cuantitativas se calculó la media y su desviación estándar (DE), realizando la comparación con la prueba t de Student o la prueba no paramétrica U de Mann-Whitney.

Se construyó un modelo explicativo de la mortalidad mediante regresión logística $(\mathrm{RL})$, partiendo de un modelo saturado donde se incluyeron todas las variables con asociación estadisticamente significativa en el análisis bivariante, calculando los correspondientes odds ratio (OR) para las variables que se mantuvieron en el modelo definitivo.

Con dichas variables se construyó una escala predictiva de mortalidad y se calculó el área bajo de curva ROC y su sensibilidad, especificidad y valores predictivos.

La significación estadística se estableció en una $p<0,05$. Los análisis se realizaron con Software Estadístico SPSS Versión 19 y Stata / SE, versión 13 (Stata Corp, College Station, TX).

El estudio fue aprobado por el comité de estudios clínicos del Hospital Universitario de La Princesa, cuyo número de Registro es $\mathrm{Pl}-893$.

\section{RESULTADOS}

Se registraron un total de 1.121 pacientes con alerta CSP activada a lo largo de los cuatro años del estudio. Durante el año 2015 se registraron 232 pacientes, en 2016 fueron 201 pacientes, en 2017 un total de 287 y en 2018 se activaron 401 pacientes.

La edad media de la población de estudio fue de $72 \pm 15$ años, no observando diferencias estadísticamente significativas a lo largo de los años del estudio. El 58,5\% fueron varones, sin variaciones en los cuatro años.

En el 80\% de los casos se activó CSP en el Servicio de Urgencias, el 9\% en UCC y el 11\% en el resto de servicios hospitalarios. 


\begin{tabular}{|c|c|c|c|c|c|c|c|}
\hline \multirow{2}{*}{\multicolumn{2}{|c|}{$\begin{array}{c}\text { Tabla } 1 \\
\text { Datos generales }\end{array}$}} & \multicolumn{6}{|c|}{ Características de los pacientes incluidos en Código Sepsis Princesa } \\
\hline & & $\mathrm{N}$ & 2015 & 2016 & 2017 & 2018 & Significación \\
\hline \multicolumn{2}{|c|}{ Edad en años (media, DE) } & 1.121 & $73 \pm 15$ & $71 \pm 15$ & $72 \pm 15$ & $73 \pm 15$ & n.s. \\
\hline \multicolumn{2}{|c|}{ Sexo: varón $(\%)$} & 1.121 & 60 & 56 & 60 & 58 & n.s. \\
\hline \multicolumn{2}{|c|}{ Servicio: Urgencias (\%) } & 1.121 & 80 & 79 & 86 & 77 & $p<0,05$ \\
\hline \multicolumn{2}{|c|}{ Datos clínicos y analíticos } & $\mathrm{N}$ & 2015 & 2016 & 2017 & 2018 & Significación \\
\hline \multicolumn{2}{|c|}{ FC, Ipm (media, DE) } & 1.105 & $103 \pm 25$ & $98 \pm 25$ & $104 \pm 23$ & $102 \pm 24$ & $p<0,05$ \\
\hline \multicolumn{2}{|c|}{ TAS, mmHg (media, DE) } & 1.107 & $108 \pm 28$ & $106 \pm 27$ & $102 \pm 25$ & $99 \pm 25$ & $p<0,05$ \\
\hline \multicolumn{2}{|c|}{ Lactato, mmol/L (media, DE) } & 1.085 & $3,4 \pm 3,1$ & $2,8 \pm 2,1$ & $3,3 \pm 2,6$ & $3,2 \pm 2,2$ & n.s. \\
\hline \multicolumn{2}{|c|}{ Procalcitonina, mg/dL (media, DE) } & 819 & $15 \pm 27$ & $9 \pm 19$ & $15 \pm 26$ & $11 \pm 20$ & $p<0,05$ \\
\hline \multicolumn{2}{|c|}{ Creatinina, mg/dL (media, DE) } & 375 & $1,7 \pm 1,1$ & $1,7 \pm 1,7$ & $1,7 \pm 1$ & $2,8 \pm 1$ & $p<0,05$ \\
\hline \multicolumn{2}{|c|}{ Datos de gravedad } & N & 2015 & 2016 & 2017 & 2018 & Significación \\
\hline \multicolumn{2}{|c|}{ SOFA (media, DE) } & 1.121 & $7,6 \pm 4,6$ & $5,1 \pm 2,9$ & $3,6 \pm 1,8$ & $3,9 \pm 2,2$ & $p<0,05$ \\
\hline \multicolumn{2}{|c|}{ Ingreso UCI (\%) } & 1.115 & 32 & 36 & 30 & 33 & n.s. \\
\hline \multicolumn{2}{|c|}{ Estancia hospitalaria en días (media, DE) } & 1.086 & $15 \pm 18$ & $22 \pm 52$ & $14 \pm 12$ & $16 \pm 16$ & $p<0,05$ \\
\hline \multicolumn{2}{|c|}{ Mortalidad (\%) } & 1.121 & 24 & 18 & 18,5 & 15 & n.s. \\
\hline
\end{tabular}

FC: frecuencia cardiaca; TAS: tensión arterial sistólica; SOFA: Sequential Organ Failure Assessment Score.

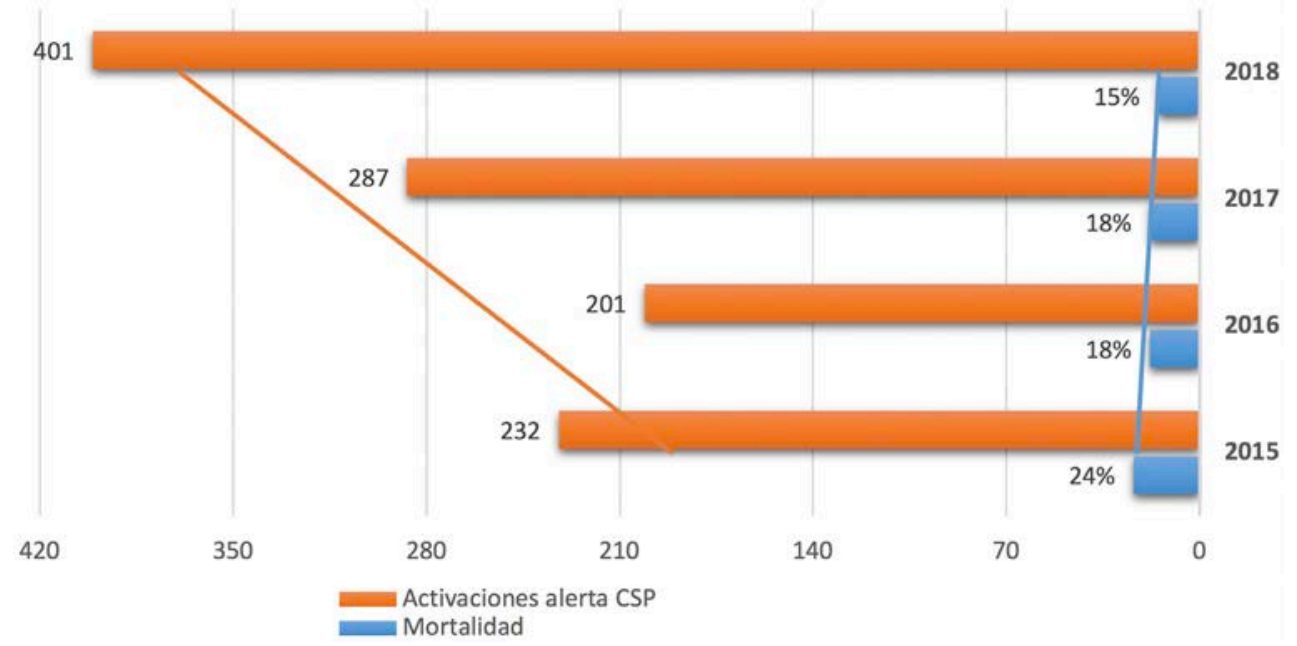

\begin{tabular}{l|l} 
Figura 1 & Evolución de la mortalidad tras la implantación de CSP - 2015-2018
\end{tabular}

La estancia media hospitalaria desde la activación de CSP fue de $16 \pm 26$ días, con variaciones a lo largo de los años del estudio. El porcentaje de pacientes que requirieron ingreso en UCC fue del 32\%, manteniéndose constante durante los años de recogida.

En la Tabla 1 se presentan las diferencias observadas, durante estos años, en las principales variables analizadas.
La mortalidad mostró una tendencia lineal descendente estadisticamente significativa $(p<0,05)$ : un $24 \%$ en los pacientes activados durante el año 2015, un 18\% en los pacientes activados en 2016 y 2017 y un 15\% de mortalidad en los pacientes activados en el año 2018. En la figura 1 se muestra la disminución de la mortalidad a medida que aumentan las activaciones de la alerta CSP a lo largo de los años incluidos en el estudio. 


\begin{tabular}{|c|c|c|c|c|c|}
\hline \multirow{3}{*}{\multicolumn{2}{|c|}{ Análisis bi }} & ante y multiv & nte de los & tores asociad & a exitus \\
\hline & & \multicolumn{2}{|c|}{ Análisis bivariante } & \multicolumn{2}{|c|}{ Análisis multivariante } \\
\hline & & OR (IC95\%) & Significación & OR (IC95\%) & Significación \\
\hline \multicolumn{2}{|c|}{ Edad > de 80 años } & $1,69(1,32-2,17)$ & $p<0,05$ & $0,92(0,41-2,10)$ & $p>0,05$ \\
\hline \multicolumn{2}{|c|}{ Sexo (\% varones) } & $1,19(0,93-1,53$ & $p>0,05$ & & \\
\hline \multicolumn{2}{|c|}{ FC, Ipm (comparación medias) } & $102 \pm 27$ vs $102 \pm 23$ & $p>0,05$ & & \\
\hline \multicolumn{2}{|c|}{ TAS, mmHg (comparación medias) } & $102 \pm 27$ vs $103 \pm 26$ & $p>0,05$ & & \\
\hline \multicolumn{2}{|c|}{ Lactato $>2 \mathrm{mmol} / \mathrm{L}$} & $2,26(1,62-3,15)$ & $p<0,05$ & $2,50(1,12-5,60)$ & $p<0,05$ \\
\hline \multicolumn{2}{|c|}{ Creatinina $>1,6 \mathrm{mg} / \mathrm{dL}$} & $2,55(1,67-3,89)$ & $p<0,05$ & $3,00(1,47-6,13)$ & $p<0,05$ \\
\hline \multicolumn{2}{|c|}{ Procalcitonina $>1 \mathrm{ng} / \mathrm{mL}$} & $1,16(0,83-1,61)$ & $p>0,05$ & & \\
\hline \multicolumn{2}{|c|}{ Activación en Urgencias } & $0,65(0,50-0,85)$ & $p<0,05$ & $0,60(0,26-1,37)$ & $p>0,05$ \\
\hline \multicolumn{2}{|l|}{ Grupo SOFA } & & $p<0,05$ & $1,24(0,54-2,82)$ & $p>0,05$ \\
\hline \multicolumn{2}{|l|}{ SOFA $<3$} & Referencia: $0 R=1$ & & & \\
\hline \multicolumn{2}{|l|}{ SOFA 3-10 } & 1,95 & & & \\
\hline \multicolumn{2}{|l|}{ SOFA $>10$} & 12,33 & & & \\
\hline \multicolumn{2}{|l|}{ Año CSP } & & $p<0,05$ & $1,24(0,55-2,78)$ & $p>0,05$ \\
\hline \multicolumn{2}{|l|}{2015} & Referencia: $\mathrm{OR}=1$ & & & \\
\hline \multicolumn{2}{|l|}{2016} & 1,26 & & & \\
\hline \multicolumn{2}{|l|}{2017} & 1,22 & & & \\
\hline \multicolumn{2}{|l|}{2018} & 1,73 & & & \\
\hline \multicolumn{2}{|c|}{ Ingreso en UCC médica o quirúrgica } & $1,22(0,95-1,57)$ & $p>0,05$ & & \\
\hline \multicolumn{2}{|c|}{ Necesidad Aminas primeras $24 \mathrm{~h}$} & $2,16(1,68-2,78)$ & $p<0,05$ & $2,64(1,26-5,52)$ & $p<0,05$ \\
\hline \multicolumn{2}{|c|}{ Antibioterapia primeras $6 \mathrm{~h}$} & $0,65(0,50-0,85)$ & $p>0,05$ & & \\
\hline
\end{tabular}

FC: frecuencia cardiaca; TAS: tensión arterial sistólica; SOFA: Sequential Organ Failure Assessment Score; CSP: Código Sepsis Princesa; UCC: Unidades de Cuidados Críticos.

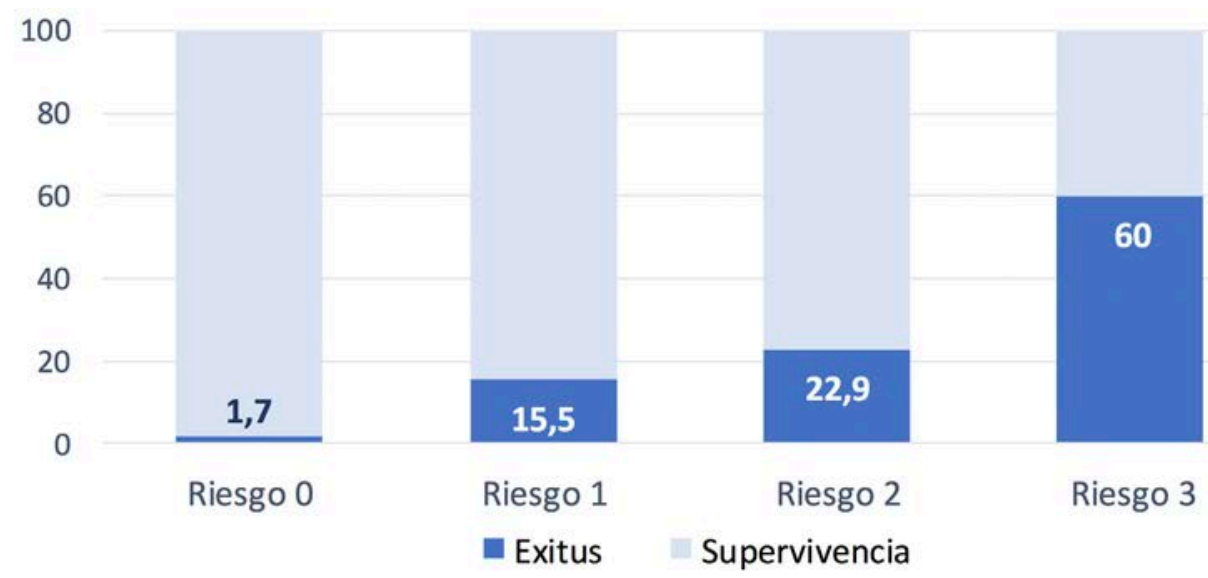

\section{\begin{tabular}{l|l} 
Figura 2 & Mortalidad según la nueva escala de riesgo CSP
\end{tabular}}

Riesgo 0 corresponde a pacientes sin ningún factor de riesgo asociado (lactato $>2 \mathrm{mmol} / \mathrm{L}$, creatinina $>1,6 \mathrm{mg} / \mathrm{dL}$, necesidad de administrar aminas); Riesgo 1: pacientes con uno de los tres factores de riesgo; Riesgo 2: pacientes con dos de los factores de riesgo; Riesgo 3: pacientes con los tres factores de riesgo presentes. CSP: Código Sepsis Princesa. 


\begin{tabular}{l|ccc}
\hline Tabla 3 & $\begin{array}{l}\text { Escala de mortalidad CSP: análisis de la capacidad } \\
\text { predictiva }\end{array}$ \\
\hline & EXITUS & NO EXITUS & TOTAL \\
\hline Presencia de alguno de los 3 factores & 69 & 215 & 284 \\
Riesgo 0 (ningún factor) & 1 & 59 & 60 \\
& 70 & 274 & \\
Capacidad predictiva de la nueva escala: & & &
\end{tabular}

Sensibilidad $=$ 98,57\% (IC95\%: 91,23-99,93)

Especificidad $=21,53 \%$ (IC95\%: 16,91-26,97)

Valor Predictivo Positivo = 24,30\% (IC95\%: 19,51-29,79)

Valor Predictivo Negativo = 98,33\% (IC95\%: 89,86-99,91)

Los factores de riesgo incluidos en la escala son: lactato $>2 \mathrm{mmol} / \mathrm{L}$, creatinina $>1,6 \mathrm{mg} / \mathrm{dL}$ y necesidad de administrar aminas en las primeras 24 horas de activación de Código Sepsis Princesa (CSP).

Según la puntuación SOFA, los pacientes se clasificaron en tres grupos, cuya distribución fue la siguiente: el 41\% de los pacientes presentaron una puntuación inferior a 3, el 54\% alcanzaron un SOFA entre 3 y 10, y el 2\% superaron los 10 puntos. Se observó que el riesgo de éxitus se duplicaba si la puntuación SOFA se encontraba entre 3 y 10 respecto a pertenecer al grupo de SOFA <3. Este riesgo fue 12 veces mayor si la puntuación SOFA superaba los 10 puntos.

En el análisis bivariante se asociaron a mortalidad la edad, la puntuación SOFA, el lactato $>2 \mathrm{mmol} / \mathrm{L}$, la creatinina $>1,6$ $\mathrm{mg} / \mathrm{dL}$, la activación de la alerta CSP fuera del servicio de urgencias, la necesidad de administrar aminas en las primeras 24 horas y el año de la activación de CSP (Tabla 2).

Para determinar las variables predictivas de mortalidad, entre aquellas con asociación estadísticamente significativa en el análisis bivariante, se construyó un modelo multivariante de regresión logistica donde se identificaron el lactato $>2$ $\mathrm{mmol} / \mathrm{L}$, la creatinina $>1,6 \mathrm{mg} / \mathrm{dL}$ y la necesidad de administrar aminas en las primeras 24 horas, con asociación independiente significativa con la mortalidad (Tabla 2).

Por este motivo, se definió una escala de riesgo, de carácter sumatorio, donde se contabilizaba la presencia o ausencia de estos tres factores: lactato $>2 \mathrm{mmol} / \mathrm{L}$, creatinina $>1,6 \mathrm{mg} /$ $\mathrm{dL}$ y/o la necesidad de administrar aminas. La nueva escala tiene un rango de 0 a 3 (según la presencia en un mismo paciente de ningún factor de riesgo, uno, dos o los tres factores), y su asociación con la mortalidad es lineal creciente $(p<0,05)$, siendo la probabilidad de éxitus: para el Riesgo-0 de un 1,7\%, para Riesgo-1 de 15,9\%, Riesgo-2 del 22,9\% y Riesgo-3 del 60\% (Figura 2).

Según el análisis de la capacidad predictiva, si el paciente no presenta ninguno de los tres factores, la nueva escala tiene una sensibilidad del $98,6 \%$ y un valor predictivo negativo del $98,3 \%$. En la Tabla 3 se presentan los resultados de la capacidad predictiva de la nueva escala.

El área bajo la curva ROC de la nueva escala fue de 0,73

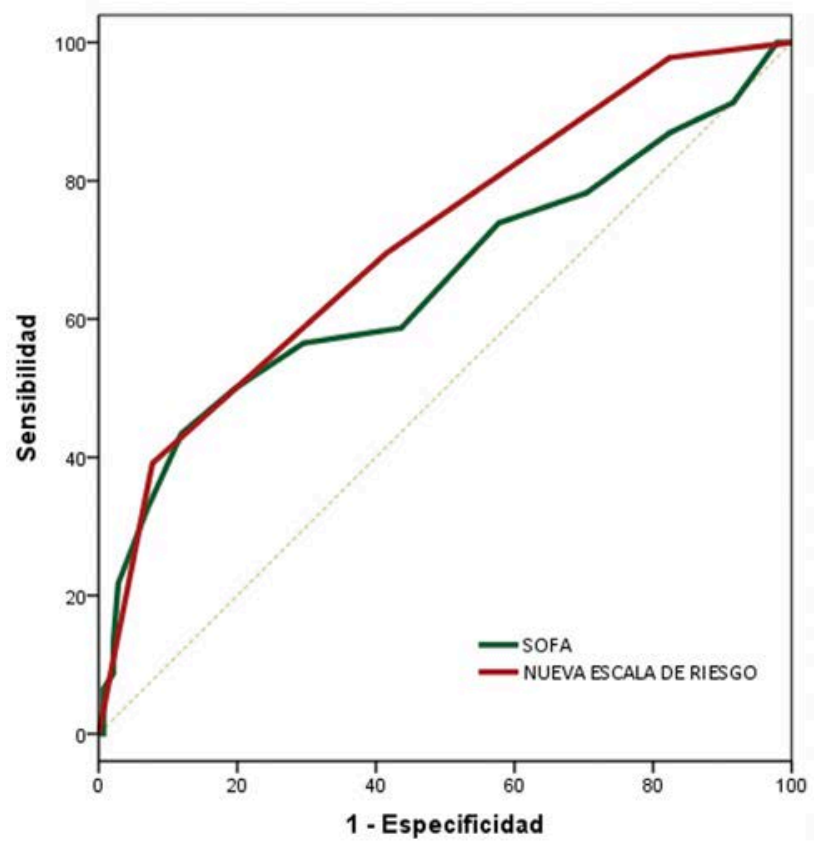

Figura $3 \quad$ Comparación de las áreas bajo la curva ROC sobre mortalidad

(IC95\%: 0,63-0,80), siendo el área bajo la curva ROC de la puntuación SOFA en los pacientes de nuestro estudio de 0,65 (IC95\%: 0,55-0,76) (Figura 3).

\section{DISCUSIÓN}

La implementación de CSP en nuestro hospital disminuyó la mortalidad de los pacientes, mostrando una tendencia lineal descendente significativa, siendo las variables asociadas a la 
mortalidad la presencia de una cifra de lactato $>2 \mathrm{mmol} / \mathrm{L}$, los niveles de creatinina $>1,6 \mathrm{mg} / \mathrm{dL}$ y la necesidad de administrar aminas en las primeras 24 horas.

Los principales ensayos clínicos en el paciente con sepsis: ProCESS [3], ARISE [4] y ProMISe [5], refieren unas cifras de mortalidad que varian del 20\% al 30\% dependiendo del ensayo, de la definición de sepsis y de la gravedad del paciente. En nuestro estudio, la mortalidad durante el primer año de implantación de CSP era de un 24\%, descendiendo hasta el 15\% cuatro años después, lo cual puede estar en relación con el cambio cultural generado en el hospital, la dotación de herramientas de diagnóstico y tratamiento, la intensa formación llevada a cabo y la conciencia de la sepsis como una patología "tiempo dependiente". Estos resultados coinciden con los publicados por el grupo de Ferreras et al. [8], los cuales publicaron una disminución de la mortalidad intrahospitalaria que previamente a la implantación de CS en Aragón era del 31,1\% y dos años después del inicio de CS disminuyó hasta el 20,7\%. En nuestro estudio no disponemos de datos de mortalidad previos a la implantación del Código.

En cuanto a las causas relacionadas con la mortalidad, el grupo de Rhee et al. [10] reportó unos interesantes resultados acerca de la mortalidad prevenible en el paciente pluripatológico con sepsis. Incluyó una cohorte de 568 pacientes que fallecieron por sepsis como causa primaria y que presentaban como causa subyacente principal: neoplasias de órgano sólido y hematológicas, insuficiencia cardiaca y enfermedad pulmonar crónica. Concluyó que el 3,7\% de las muertes eran definitiva o moderadamente prevenibles, siendo el 8,3\% de los éxitus catalogados como posiblemente prevenibles, relacionándolo con tres causas principales: el retraso en el tratamiento antibiótico, el retraso en el control del foco y la antibioterapia inapropiada.

En nuestro estudio analizamos la edad, el sexo y variables clínicas y analíticas, encontrando una asociación significativa independiente con la mortalidad en aquellos pacientes que presentaban un lactato $>2 \mathrm{mmol} / \mathrm{L}$, una creatinina $>1,6 \mathrm{mg} /$ $\mathrm{dL}$ y la necesidad de administrar aminas en las primeras 24 horas, si bien no llevamos a cabo el análisis de los antecedentes personales que pudieran influir en la mortalidad. Teniendo en cuenta estas tres variables realizamos una nueva escala de predicción de mortalidad a nivel local, contabilizando la presencia 0 ausencia de estos factores y encontrando una asociación lineal creciente significativa con la mortalidad, siendo la probabilidad de éxitus para los pacientes que presentan los tres factores de riesgo de un 60\%, con una área bajo la curva ROC prometedora y con un valor predictivo negativo del $98,3 \%$, que nos permitiria descartar con relativa seguridad a los pacientes que presentan menor riesgo de muerte. Esta escala en nuestra serie es superior en capacidad predictiva de mortalidad a la escala SOFA [1], siendo más sencilla y resultando su diferencia más significativa la introducción del lactato como variable predictiva.

En un sentido similar, el grupo de Seymour et al. [11] publicó un estudio con 49.331 pacientes con sepsis y evaluó el aumento del riesgo de morir en relación con el cumplimiento de los paquetes de medidas (bundles) en las primeras tres horas: extracción de hemocultivos, valoración de la cifra de lactato y administración de antibioterapia de amplio espectro. La conclusión fue que cada hora de retraso en completar los paquetes de medidas, aumentaba de manera exponencial la probabilidad de muerte (OR 1,04 por cada hora), principalmente en aquellos pacientes con aminas. Resultados similares publicaron Reinhart et al. [12], concluyendo que la sepsis es la mayor causa de mortalidad y morbilidad prevenible dado que, en un número significativo de pacientes, los resultados dependían de la aplicación de medidas precoces como la administración del antibiótico o el control del foco.

En nuestro estudio encontramos una relación estadísticamente significativa de la mortalidad con la cifra de lactato > $2 \mathrm{mmol} / \mathrm{L}$ al inicio de la activación de la alerta, en las primeras 6-12 horas y en las 12-24 horas de la evolución del cuadro clinico, asi como con la necesidad de administrar aminas en cualquier momento durante las primeras 24 horas de activación de CSP, sin encontrar ninguna asociación con el retraso en la administración del antibiótico más allá de las primeras 6 horas.

El grupo de Rhee et al. [13] publicó un estudio acerca de la incidencia y la tendencia de la mortalidad de los pacientes con sepsis desde 2009 hasta 2014 según las nuevas definiciones de sepsis-3 [1] en 409 hospitales en USA y concluyó que, ni la incidencia ni la mortalidad de la sepsis han disminuido a lo largo de esos años, refiriendo una estancia media de los pacientes de 12 dias y encontrando una mortalidad del 25\% asociada principalmente al paciente anciano, el sexo masculino y el tipo de hospital (docente y de gran tamaño). Lo más destacable es que la mortalidad disminuyó hasta un $7 \%$ en aquellos hospitales que tenían implementado algún tipo de código de actuación especifico del paciente con sepsis y en los que incluían el lactato en los criterios de vigilancia. De manera similar, en nuestro estudio encontramos una disminución lineal decreciente de la mortalidad a medida que CSP se ha instaurado en la cultura del hospital, sin encontrar una asociación significativa de la mortalidad con la edad ni con el sexo. La estancia media de los pacientes incluidos en nuestro estudio fue de 16 días, con una necesidad de ingreso en UCC del 32\% que se mantiene similar a lo largo de todos los años analizados y que es algo superior a la referida en la bibliografia [3-5].

Nuestro estudio presenta limitaciones, siendo la principal que se trata de un estudio retrospectivo donde no existe un grupo control de pacientes sin activación de código sepsis para poder encontrar diferencias significativas de mortalidad entre ambos. Además, no se han recogido las patologías previas del paciente como en otros estudios presentes en la bibliografia, que podrían estar asociadas con la mortalidad. Por último y a la vista de los buenos resultados encontrados, sería necesario realizar un estudio multicéntrico con hospitales que incluyan modelos de actuación similares para evaluar el impacto global en la mortalidad.

La implementación de modelos de actuación tipo "Código Sepsis" disminuye la mortalidad de los pacientes con sepsis y 
shock séptico, por lo que recomendamos su implantación para la detección y el tratamiento precoz de esta patología.

La presencia de una cifra de lactato $>2 \mathrm{mmol} / \mathrm{L}$, los niveles de creatinina $>1,6 \mathrm{mg} / \mathrm{dL}$ y/o la necesidad de administrar aminas en las primeras 24 horas, se asocian con un aumento de la mortalidad en el paciente con sepsis, mayor cuantos más factores convergen en un mismo paciente, indicando en ellos la necesidad de extremar la vigilancia y la posibilidad de precisar el ingreso en una Unidad de Cuidados Críticos.

\section{AGRADECIMIENTOS}

A todos los miembros del grupo Código Sepsis Princesa por su intensa y altruista labor en la mejora del diagnóstico y tratamiento del paciente con sepsis.

\section{FINANCIACIÓN}

Los autores declaran que no han recibido financiación para la realización de este trabajo.

\section{CONFLICTO DE INTERÉS}

Los autores declaran no tener ningún conflicto de intereses.

\section{BIBLIOGRAFÍA}

1. Singer M, Deutschman CS, Seymour CW, et al. The Third International Consensus Definitions for Sepsis and Septic Shock (Sepsis-3). JAMA 2016;315(8):801-10. doi: 10.1001/jama.2016.0287.

2. Rhodes A, Evans LE, Alhazzani W, et al. Surviving Sepsis Campaign: International Guidelines for Management of Sepsis and Septic Shock: 2016 . Intensive Care Med. 2017;43(3):304-377. doi: 10.1007/s00134-017-4683-6.

3. The ProCESS Investigators. A Randomized Trial of Protocol-Based Care for Early Septic Shock. N Engl J Med 2014;370:1683-1693. doi:10.1056/NEJMoa1401602.

4. The ARISE Investigators and the ANZICS Clinical Trials Group. GoalDirected Resuscitation for Patients with Early Septic Shock. N Engl J Med 2014;371:1496-1506. doi: 10.1056/NEJMoa1404380.

5. Mouncey PR, Osborn TM, Power GS, et al. Protocolised Management In Sepsis (ProMISe): a multicentre randomised controlled trial of the clinical effectiveness and cost-effectiveness of early, goal-directed, protocolised resuscitation for emerging septic shock. Health Technol Assess. 2015;19(97):i-xxv, 1-150. doi: 10.3310/ hta 19970

6. Palencia Herrejón E, González del Castillo J, Ramasco Rueda F, et al. Documento de consenso para la implantación y desarrollo del Código Sepsis en la Comunidad de Madrid. Rev Esp Quimioter 2019;32(4): 400-409. PMID: 31345006.

7. Yébenes JC, Lorencio C, Esteban E, et al. Interhospital sepsis code in Catalonia (Spain): territorial model for initial care of patients with sepsis. Med Intensiva 2020;44 (1): 36-45. doi: 10.1016/j.medin.2019.05.008.

8. Ferreras Amez JM, Arribas Entrala B, Sarrat Torres MA et al. Evaluación de los resultados antes y después de la implantación del Código Sepsis en Aragón. Emergencias 2017;29:154-160.

9. Ramasco $F$, Figuerola $A$, Méndez $R$, et al. Initial clinical outcomes and prognostic variables in the implementation of a Code Sepsis in a high complexity University Hospital. Rev Esp Quimioter. 2019;32(3):238-245. PMID: 30968675

10. Rhee $\mathrm{C}$, Jones TM, Hamad $Y$, et al. Prevalence, Underlying Causes, and Preventability of Sepsis-Associated Mortality in US Acute Care Hospitals. JAMA Netw Open. 2019;2(2):e187571. doi:10.1001/jamanetworkopen.2018.7571.

11. Seymour CW, Gesten F, Prescott HC, et al. Time to Treatment and Mortality during Mandated Emergency Care for Sepsis. N Engl J Med. 2017;376(23):2235-2244. doi: 10.1056/NEJMoa1703058.

12. Reinhart K, Daniels RD, Schwarzkopf D, et al. Sepsis hysteria: facts versus fiction. Intensive Care Med. 2020;46(7):1477-1480. doi: 10.1007/s00134-020-06001-w.

13. Rhee $C$, Dantes $R$, Epstein $L$, et al. Incidence and Trends of Sepsis in US Hospitals Using Clinical vs Claims Data, 2009-2014. JAMA. 2017;318(13):1241-1249. doi: 10.1001/jama.2017.13836. 
Rafael Rubio Díaz Elena de Rafael González² Esther Martín Torres ${ }^{2}$ Elena Valera Núñez ${ }^{2}$ Aurora María López Martos² David Melguizo Melguizo ${ }^{2}$ Maria Piedad Picazo Perea ${ }^{2}$ Pedro Jesús López García ${ }^{2}$ Patricia Fuentes Bullejos ${ }^{2}$ Matilde Chafer Rudilla ${ }^{2}$ Julián Fabián Carretero Gómez ${ }^{2}$

Maria Carmen Lorenzo Lozano ${ }^{2}$ Agustín Julián-Jiménez ${ }^{1,3}$

\section{Poder pronóstico de mortalidad a corto plazo del receptor soluble activador del plasminógeno tipo uroquinasa (suPAR) en los pacientes atendidos en urgencias por infección}

\author{
'Servicio de Urgencias, Complejo Hospitalario Universitario de Toledo, Toledo, España. \\ ${ }^{2}$ Servicio de Análisis Clínicos y Bioquímica, Complejo Hospitalario Universitario de Toledo, Toledo, \\ España. \\ ${ }^{3}$ Universidad de Castilla La Mancha
}

Article history

Received: 29 July 2021; Revision Requested: 21 September 2021; Revision Received: 28 October 2021; Accepted: 30 October 2021; Published: 3 December 2021

\section{RESUMEN}

Objetivos. Analizar y comparar el poder predictivo de mortalidad a 30 dias de varios biomarcadores (proteina $\mathrm{C}$ reactiva, procalcitonina, lactato y suPAR) en los pacientes que acuden al servicio de urgencias (SU) por un episodio de infección. $Y$, secundariamente, si estos mejoran la capacidad pronóstica de los criterios de sepsis (síndrome de respuesta inflamatoria sistémica-SRIS- y del quick Sepsis-related Organ Failure Assessment-qSOFA-).

Métodos. Estudio observacional, prospectivo y analítico. Se incluyó consecutivamente a pacientes atendidos en un SU por un proceso infeccioso. Se analizaron 32 variables independientes (epidemiológicas, de comorbilidad, funcionales, clínicas y analiticas) que pudieran influir en la mortalidad a corto plazo (30 dias).

Resultados. Se incluyó a 347 pacientes, de los que 54 $(15,6 \%)$ habian fallecido a los 30 días tras su consulta en el SU. El suPAR es el biomarcador que consigue la mayor área bajo la curva ( $A B C)-R O C$ para predecir mortalidad a los 30 dias de 0,836 [IC 95\%: 0,765-0,907; $p<0,001$ ] y el punto de corte elegido con mayor capacidad predictiva es $10 \mathrm{ng} / \mathrm{ml}$, que ofrece una sensibilidad 70\%, especificidad de $86 \%$. La escala qSOFA $\geq 2$ consigue ABC-ROC de 0,707 [IC 95\%: 0,621$0,793 ; p<0,001]$ con sensibilidad de $53 \%$ y especificidad de $89 \%$. El modelo combinado (suPAR $>10 \mathrm{ng} / \mathrm{ml}$ con $\mathrm{qSOFA} \geq$ 2) mejora el $A B C-R O C$ a 0,853 [IC 95\%: 0,790-0,916; $p<0,001$ ] y ofrece el mejor rendimiento pronóstico con una sensibilidad de $39 \%$, especificidad del $97 \%$ y un valor predictivo negativo de $90 \%$.

Correspondencia:

Dr. Agustin Julián-Jiménez, MD, PhD

Servicio de Urgencias-Coordinador de Docencia, Formación, Investigación y Calidad.

Complejo Hospitalario Universitario de Toledo, Toledo, España.

Avda. de Barber no 30. C.P: 45.004

Teléfono: +34925269200-ext 48560 - FAX: +34925269372

E-mail: agustinj@sescam.jccm.es
Conclusiones. En los pacientes que acuden al SU por un episodio de infección, suPAR presenta una capacidad pronóstica de mortalidad a los 30 dias superior al resto de biomarcadores, la qSOFA obtiene mayor rendimiento que los criterios de SRIS, y el modelo combinado qSOFA $\geq 2$ con suPAR $>10 \mathrm{ng} /$ $\mathrm{mL}$ mejora el poder predictivo de qSOFA.

Palabras clave: Biomarcadores. Servicio de Urgencias. Pronóstico. Mortalidad. Procalcitonina. Lactato. Proteína C reactiva. Receptor soluble del activador del plasminógeno de tipo uroquinasa

\section{Prognostic power of soluble urokinase plasminogen activator receptor (suPAR) for short-term mortality in patients seen in Emergency Departments due to infections}

\section{ABSTRACT}

Objectives. To analyse and compare 30-day mortality prognostic power of several biomarkers (C-reactive protein, procalcitonin, lactate and suPAR) in patients seen in emergency departments (ED) due to infections. Secondly, if these could improve the accuracy of systemic inflammatory response syndrome (SIRS) and quick Sepsis-related Organ Failure Assessment (qSOFA).

Methods. A prospective, observational and analytical study was carried out on patients who were treated in an ED of one of the eight participating hospitals. An assessment was made of 32 independent variables that could influence mortality at 30 days. They covered epidemiological, comorbidity, functional, clinical and analytical factors.

Results. The study included 347 consecutive patients, 54 (15.6\%) of whom died within 30 days of visiting the ED. SUPAR has got the best biomarker area under the curve (AUC)-ROC to predict mortality at 30 days of 0.836 (95\% Cl: $0.765-0.907 ; \mathrm{P}<$ .001) with a cut-off $>10 \mathrm{ng} / \mathrm{mL}$ who had a sensitivity of $70 \%$ and a specificity of $86 \%$. The score qSOFA $\geq 2$ had AUC-ROC of 
0.707 (95\% Cl: 0.621-0.793; P < .001) with sensitivity of 53\% and a specificity of $89 \%$. The mixed model (suPAR $>10 \mathrm{ng} / \mathrm{mL}$ plus qSOFA $\geq 2$ ) has improved the AUC-ROC to $0.853[95 \% \mathrm{Cl}$ : $0.790-0.916 ; \mathrm{P}<.001]$ with the best prognostic performance: sensitivity of $39 \%$ and a specificity of $97 \%$ with a negative predictive value of $90 \%$.

Conclusions. suPAR showed better performance for 30day mortality prognostic power from several biomarkers in the patients seen in ED due to infections. Score qSOFA has better performance that SRIS and the mixed model (qSOFA $\geq 2$ plus suPAR $>10 \mathrm{ng} / \mathrm{mL}$ ) increased the ability of qSOFA.

Keywords: Biomarkers. Emergency Department. Elderly. Prognosis. Mortality. Procalcitonin. Lactate. C-reactive protein. Soluble urokinase-type plasminogen activator receptor (suPAR)

\section{INTRODUCCIÓN}

La atención de pacientes con sospecha o confirmación de un proceso infeccioso en los servicios de urgencias hospitalarios (SUH) españoles se ha incrementado significativamente en los últimos años hasta suponer alrededor del 15\% de las atenciones diarias $[1,2]$. Además, la gravedad de su presentación clínica (aquellos que cumplen criterios de sepsis, pacientes con comorbilidad relevante, neutropénicos, ancianos, ante la sospecha de bacteriemia, es decir, lo que hoy en día se conoce como infección grave) y la mortalidad registrada a corto plazo (30 dias) también han sufrido un incremento en la última década $[1,2]$. Incluso, durante el último año donde los SUH se han visto impactados por la pandemia de COVID-19, tanto estos pacientes como los atendidos por infección bacteriana han aumentado su tasa de ingresos, la necesidad de cuidados intensivos y la mortalidad a corto plazo [3].

En este escenario, el paciente con sospecha o confirmación de infección grave en el SUH y, más concretamente, el que cumple criterios definitorios de sepsis, se convierte en un reto diagnóstico de primer orden. La incidencia de este proceso en dichos servicios se pueden estimar con fiabilidad, aunque depende de los registros de cada centro, región o pais $[2,4,5]$. En estos pacientes será clave establecer un diagnóstico precoz e implementar un tratamiento inmediato adecuado (antimicrobiano y de soporte). Estas actuaciones tendrán implicaciones directas en el pronostico de este tipo de pacientes $[4,5]$.

Por otro lado, encontrar la definición de sepsis que se adapte a los objetivos de diagnóstico y pronóstico útiles en el SUH continúa siendo un problema recurrente y controvertido. Desde hace años, diferentes grupos de trabajo y sociedades han intentado buscar una definición que consiga una sensibilidad y especificidad óptimas que permita al clínico establecer una rápida actuación [6]. Las primeras definiciones (Sepsis-1 y Sepsis-2) condicionaban el diagnóstico a la presencia de una respuesta fisiológica ante distintas agresiones (sindrome de respuesta inflamatoria sistémica- SRIS-) y la sospecha o presencia demostrada de una infección [7]. Estas definiciones se confirmaron como bastante sensibles pero poco específicas, lo que originó la necesidad de la aparición del consenso Sepsis-3 [8], en el que se estipulaba el daño orgánico como eje central de la nueva definición de sepsis y, por tanto, la probabilidad de que el paciente fuera a fallecer $[8,9]$.

En el SUH resulta imprescindible la sospecha y diagnóstico de la infección grave o sepsis, pero también es necesario estimar el pronóstico del paciente. Por ello, distintos autores y Sociedades creen necesario mejorar la definición de sepsis (y llegar a la Sepsis-4) de forma que contenga variables fácilmente obtenibles en los SUH, entre ellos los biomarcadores (BM), para que ésta sea capaz de diagnosticar precozmente al paciente con sepsis y estratificar su riesgo de muerte o gravedad al mismo tiempo $[2,6,10]$.

Aunque han sido múltiples los BM estudiados en los SUH y su utilidad de forma individual o combinada entre ellos o con otras variables (lo que se conoce como la sinergia de los BM), hoy en día se recomienda la utilización conjunta de los conocidos como BM de diagnóstico de infección bacteriana, bacteriemia y sepsis (a la cabeza la procalcitonina) y aquellos que consiguen el mejor rendimiento pronóstico (entre otros lactato y suPAR) $[11,12]$.

La procalcitonina (PCT) se sintetiza en situaciones de infección bacteriana y sepsis y sus concentraciones tienen relación con la carga bacteriana y/o la concentración de endotoxina, la existencia de bacteriemia y el pronóstico de mortalidad [12-15]. El lactato es considerado el mejor marcador de hipoperfusión e hipoxia tisular y sus valores $>2 \mathrm{mmol} / \mathrm{l}$ constituyen un poderoso factor independiente de mortalidad $[12,16]$. Asimismo, distintos estudios han evaluado el papel del receptor soluble del activador del plasminógeno de tipo uroquinasa (suPAR) en el diagnóstico de sepsis y pronóstico de mortalidad, reingreso y tiempo de estancia hospitalaria $[17,18]$.

La proteína $C$ reactiva (PCR) es una proteína de fase aguda liberada en los hepatocitos tras la estimulación de la interleucina (IL)-6 e IL-8 en respuesta a cualquier tipo de inflamación aguda, incluyendo infecciones viricas, bacterianas localizadas y otros procesos inflamatorios, y está involucrada en diferentes funciones inmunológicas. Por ello, aunque muy utilizada en los SUH, plantea limitaciones en su capacidad diagnóstica y pronóstica $[2,12]$.

Desde 1991, se conoce que suPAR participa en una gama de funciones efectoras inmunológicas que incluyen la adhesión celular, migración, quimiotaxis, proteólisis, activación inmune, remodelación tisular, invasión y transducción de señales [1924]. Cuando un patógeno invade el torrente sanguíneo, estas funciones efectoras se activan y la concentración sérica de suPAR refleja la gravedad de la infección. Esta molécula presenta una importante estabilidad in vitro en suero y plasma con poca variabilidad de sus concentraciones en un individuo a lo largo del dia $[23,24]$. Cada vez son más los estudios que confirman la capacidad pronóstica de reingreso, gravedad y mortalidad de todo tipo de pacientes atendidos en los SUH [17-19,25], pero aún son pocos los especificos de pacientes atendidos por infección [25].

El objetivo de este estudio fue analizar la utilidad y capacidad de varios BM (PCR, PCT, suPAR y lactato) para pronosticar mortalidad a corto plazo (30 días) en los pacientes que acuden 
al SUH por un episodio de infección. Y, secundariamente, comprobar si estos podrian mejorar la capacidad pronóstica de los criterios clásicos de sepsis (SRIS) [7] y del qSOFA (quick Sepsis Related Organ Failure Assessment) [8].

\section{PACIENTES Y MÉTODOS}

Diseño y sitio del estudio. Estudio observacional, prospectivo y analítico de pacientes adultos ( $\geq 18$ años) diagnosticados de un proceso infeccioso en un SUH. Se realizó seguimiento de los pacientes durante 30 dias.

El estudio fue elaborado en un hospital universitario de tercer nivel de 786 camas perteneciente al Servicio de Salud de Castilla La Mancha.

Periodos de estudio y población incluida. Desde octubre de 2019 hasta septiembre de 2020 se incluyeron mediante un muestreo por oportunidad (cuando los investigadores estuvieron de guardia) a los pacientes con 18 o más años que fueron diagnosticados por la sospecha clínica y/o confirmación posterior de un proceso infeccioso en el SUH y en los que, por sus características epidemiológicas y de posible gravedad clínica, los médicos responsables indicaron la obtención de muestras analíticas para realizar hemograma, bioquímica y distintos BM (PCR, PCT, lactato y suPAR), así como hemocultivos (HC) para descartar bacteriemia. Se excluyeron los pacientes de pediatría y obstetricia-ginecología.

Variables recogidas. Como variable dependiente se consideró la mortalidad cruda a los 30 días. Como variables independientes se recogieron aquellas que se consideraron interesantes y que pudieran influir en el pronóstico y evolución del paciente durante los 30 dias posteriores a la visita al SUH. Todas ellas se muestran en la tabla 1:

a) Demográficas-epidemiológicas: edad, sexo, institucionalización, toma de antibióticos en las 72 horas previas, ingreso en el último mes, de comorbilidad (indice de Charson [26] y dicotomizado $\geq 3$ ).

b) Clínicas: temperatura en grados centígrados (C) y dicotomizada $>38,3^{\circ} \mathrm{C}$ y $<35^{\circ} \mathrm{C}$, alteración de la consciencia definida con $\leq 14$ puntos en la escala del coma de Glasgow, existencia de náuseas/vómitos, escalofríos/tiritona, presión arterial sistólica (PAS) y PAS $<90 \mathrm{mmHg}$, criterios de sepsis y las variables que los definen según la conferencia de expertos de sepsis de 2001 [7], definición de sepsis según un qSOFA $\geq 2$ y de shock séptico y las variables que la constituyen según la tercera conferencia de consenso de sepsis (Sepsis-3) [8].

c) De evolución y destino: tiempo en días desde el inicio de la clínica referido por el paciente, estancia hospitalaria en dias, destino inicial de los pacientes, reconsulta/readmisión en 30 dias tras el alta desde el SUH.

d) De Microbiología y laboratorio de bioquímica: la existencia de bacteriemia verdadera, insuficiencia renal si creatinina $>2 \mathrm{mg} / \mathrm{dl}$, el recuento de leucocitos (así como la existencia de leucocitosis $>12.000 / \mathrm{mm}^{3}$ o leucopenia $<4.000 / \mathrm{mm}^{3}$ o una proporción de cayados o bandas $>10 \%$ ), recuento de plaquetas (y trombopenia $<150.000 / \mathrm{mm}^{3}$ ) y determinaciones de los BM incluidos (PCR en $\mathrm{mg} / \mathrm{L}$, PCT en $\mathrm{ng} / \mathrm{ml}$, lactato sérico en $\mathrm{mmol} / \mathrm{L}$ y suPAR en $\mathrm{ng} / \mathrm{ml}$ ) y distintas dicotomizaciones de los mismos (Tabla 1) utilizadas y seleccionadas según las publicaciones previas del grupo INFURG-SEMES (grupo de estudio de infecciones de la Sociedad Española de Medicina de Urgencias y Emergencias) $[2,3,10,13,15]$.

Definiciones, técnicas y métodos establecidos para las muestras. La extracción de los hemocultivos $(\mathrm{HC})$ se realizó por la técnica estándar por venopunción cutánea. En cada paciente se realizaron dos extracciones separadas entre si en el tiempo (y asegurando que los sitios de venopunción eran diferentes). En el caso de sospecha de endocarditis se obtuvieron 3 parejas de HC. Por cada extracción (HC) se inocularon 2 botellas (BD BACTEC $\left.{ }^{\circledast}\right)$ : una con medios para aerobiosis y otra para anaerobiosis. El tiempo de incubación de los HC fue de 5-7 dias (excepto en los casos de sospecha de endocarditis donde se prolongó hasta 30 dias). Se adoptó como definición de bacteriemia verdadera (o significativa) la utilizada en un reciente estudio del grupo INFURG-SEMES [15].

Para los BM se adoptaron como valores de referencia los de nuestro laboratorio. Así, para la PCR el rango de referencia era de 0-8 mg/L con el método de determinación por inmunoanálisis enzimático cuantititivo (Slides VITROS CRP® de OrthoClinical Diagnostics ${ }^{\circledR}$ ) con una sensibilidad de $2,7 \mathrm{mg} / \mathrm{L}$. Para la PCT se utilizaron como valores de referencia los menores de $0,5 \mathrm{ng} / \mathrm{ml}$ con inmunoanálisis cuantititivo de electroquimioluminiscencia (ELECSYS-BRAHMS PCT ${ }^{\circledR}$, de Roche Diagnóstics ${ }^{\circledR}$ ), con una sensibilidad de $0,02 \mathrm{ng} / \mathrm{ml}$. Para el lactato en sangre total se consideraron dentro del rango de referencia concentraciones de 5-20 mg/dL (0,5-2,2 mmol/L) con determinación por amperometría (GEM5000 de Werfen ${ }^{\circledR}$ ) con una sensibilidad de 0,3 mmol/L. Para suPAR se adoptaron como valores de referencia concentraciones por debajo de 3,5 $\mathrm{ng} / \mathrm{mL}$ en las mujeres y de $3 \mathrm{ng} / \mathrm{mL}$ en hombres utilizando el método suPARnostic ${ }^{\circledR}$ Quick Triage test de acuerdo con las instrucciones del fabricante (ViroGates A/S, Birkerød, Danmark) con un limite de detección de $2 \mathrm{ng} / \mathrm{mL}$. En este método los resultados se obtienen en un rango entre 2-15 $\mathrm{ng} / \mathrm{ml}$. Si los resultados exceden este rango se asignarán a valores $<2 \mathrm{ng} / \mathrm{ml} 0>15 \mathrm{ng} / \mathrm{ml}$, siendo retirados de la muestra al no poder ser precisados ni validados, tal y como indica el fabricante.

Análisis estadístico. Para el análisis de la asociación entre la mortalidad y las variables independientes se utilizaron medias y sus desviaciones estándar (DE) para variables cuantitativas y porcentajes para las cualitativas. Se utilizaron las pruebas de Ji al cuadrado o exacta de Fisher, la t de Student y la U de MannWhitney, según fueran aplicables, para investigar la relación entre mortalidad y las variables independientes (y aquellas que se dicotomizaron). Se consideró como significativo un valor de $p<0,05 y$ todos los contrastes fueron bilaterales.

Se realizó un análisis descriptivo (números absolutos y porcentajes) de ambos grupos de pacientes (fallecidos o no a los 30 días) en relación con el foco/diagnóstico clínico realizado en el SUH. 


\begin{tabular}{|c|c|c|c|c|c|c|}
\hline \multirow[t]{4}{*}{ Tabla 1} & \multicolumn{6}{|c|}{$\begin{array}{l}\text { Características clínico-epidemiológicas, de comorbilidad, de evolución } \\
\text { y analíticas estudiadas en la primera valoración del paciente en el SUH } \\
\text { (análisis univariable) }\end{array}$} \\
\hline & & Total & Valores & Supervivientes & Fallecidos & Valor $p$ \\
\hline & & $n=347$ & perdidos & a 30 dias & a 30 días & \\
\hline & & $(\%)$ & $\mathrm{n}(\%)$ & $n=293(84,4 \%)$ & $n=54(15,6 \%)$ & \\
\hline \multicolumn{7}{|c|}{ DATOS DEMOGRÁFICOS-EPIDEMIOLÓGICOS } \\
\hline \multicolumn{2}{|c|}{ Edad (años), media (DE) } & $66,84(20,23)$ & $0(0,0)$ & $64,57(20,32)$ & $79,15(14,62)$ & $<0,001$ \\
\hline \multicolumn{2}{|l|}{ Edad $>65$ años } & $206(59,4)$ & $0(0,0)$ & $161(54,9)$ & $45(83,3)$ & $<0,001$ \\
\hline \multicolumn{2}{|c|}{ Género masculino } & $186(53,6)$ & $0(0,0)$ & $158(53,9)$ & $28(51,9)$ & 0,447 \\
\hline \multicolumn{2}{|c|}{ Institucionalizado } & $40(11,5)$ & $0(0,0)$ & $28(9,6)$ & $12(22,2)$ & 0,011 \\
\hline \multicolumn{2}{|c|}{ Toma de AB en 72 horas previas } & $134(38,6)$ & $26(7,5)$ & $115(39,2)$ & $19(35,2)$ & 0,288 \\
\hline \multicolumn{2}{|c|}{ Ingreso en el último mes previo } & $32(9,2)$ & $0(0,0)$ & $27(9,2)$ & $5(9,3)$ & 0,578 \\
\hline \multicolumn{7}{|c|}{ COMORBILIDADES } \\
\hline \multicolumn{2}{|c|}{ İndice de Charlson a [media (DE)] } & $2,76(2,49)$ & $0(0,0)$ & $2,61(2,48)$ & $3,56(2,45)$ & 0,010 \\
\hline \multicolumn{2}{|c|}{ İndice de Charlson $\geq 3$} & $155(44,7)$ & $0(0,0)$ & $120(41,0)$ & $35(64,8)$ & 0,001 \\
\hline \multicolumn{7}{|c|}{ DATOS CLÍNICOS Y DE GRAVEDAD } \\
\hline \multicolumn{2}{|c|}{ Temperatura en grados centígrados [media (DE)] } & $37,78(0,98)$ & $0(0,0)$ & $37,80(0,96)$ & $37,66(1,08)$ & 0,344 \\
\hline \multicolumn{2}{|c|}{ Temperatura $>38,3^{\circ} \mathrm{C}$} & $95(27,4)$ & $0(0,0)$ & $81(27,6)$ & $14(25,9)$ & 0,469 \\
\hline \multicolumn{2}{|c|}{ Temperatura $<35^{\circ} \mathrm{C}$} & $2(0,6)$ & $0(0,0)$ & $1(0,3)$ & $1(1,9)$ & 0,287 \\
\hline \multicolumn{2}{|c|}{ FC en Ipm [media (DE)] } & $98,04(23,65)$ & $1(0,3)$ & $97,18(23,54)$ & $102,67(23,88)$ & 0,118 \\
\hline \multicolumn{2}{|c|}{$\mathrm{FC}>90 \mathrm{lpm}$} & $237(68,3)$ & $1(0,3)$ & $197(67,2)$ & $40(74,1)$ & 0,047 \\
\hline \multicolumn{2}{|c|}{ FR en rpm [media (DE)] } & $21,33(13,09)$ & $3(0,9)$ & $21,11(11,81)$ & $22,48(18,66)$ & 0,046 \\
\hline \multicolumn{2}{|c|}{$F R \geq 22 \mathrm{rpm}$} & $137(39,8)$ & $3(0,9)$ & $113(38,8)$ & $24(45,3)$ & 0,232 \\
\hline \multicolumn{2}{|c|}{ Alteración de la consciencia ECG $\leq 14$} & $69(19,9)$ & $2(0,6)$ & $41(14,0)$ & $28(51,9)$ & $<0,001$ \\
\hline \multicolumn{2}{|c|}{ PAS en mmHg [media (DE)] } & $122,46(26,15)$ & $0(0,0)$ & $125,33(24,60)$ & $106(28,95)$ & 0,077 \\
\hline \multicolumn{2}{|c|}{$\mathrm{PAS}<100 \mathrm{mmHg}$} & $70(20,2)$ & $0(0,0)$ & $44(15,0)$ & $26(48,1)$ & $<0,001$ \\
\hline \multicolumn{2}{|c|}{ Criterios de sepsis (SRIS $\geq 2$ ) } & $227(65,8)$ & $2(0,6)$ & $187(64,0)$ & $40(75,5)$ & 0,070 \\
\hline \multicolumn{2}{|l|}{$q S O F A \geq 2$} & $61(17,8)$ & $4(1,2)$ & $33(11,4)$ & $28(52,8)$ & $<0,001$ \\
\hline \multicolumn{2}{|c|}{ Criterios Shock séptico (Sepsis-3) } & $32(9,2)$ & $0(0,0)$ & $14(4,8)$ & $18(33,3)$ & $<0,001$ \\
\hline Náuseas/vómi & & $83(23,9)$ & $5(1,4)$ & $70(23,9)$ & $13(24,1)$ & 0,784 \\
\hline Escalofrios/Tir & & $160(46,1)$ & $0(0,0)$ & $137(46,8)$ & $23(42,6)$ & 0,340 \\
\hline DATOS DE EVC & N Y DESTINO & & & & & \\
\hline Dias desde ini & a clínica [media (DE)] & $3,71(4,51)$ & $10(2,8)$ & $3,61(4,45)$ & $4,29(4,86)$ & 0,318 \\
\hline Destino inicial & pacientes & & $0(0,0)$ & & & $<0,001$ \\
\hline Alta & & $92(26,5)$ & $0(0,0)$ & $91(31,1)$ & $1(1,9)$ & \\
\hline Observació & 24 horas) & $36(10,4)$ & $0(0,0)$ & $34(11,6)$ & $2(3,7)$ & \\
\hline Unidad cor & & $18(5,2)$ & $0(0,0)$ & $17(5,8)$ & $1(1,9)$ & \\
\hline Planta de $\mathrm{h}$ & zación convencional & $179(52,5)$ & $0(0,0)$ & $143(48,6)$ & $37(68,6)$ & \\
\hline Unidad de & s Intensivos & $22(6,3)$ & $0(0,0)$ & $9(3,1)$ & $13(24,1)$ & \\
\hline Estancia hospi & en dias [media (DE)] & $6,15(7,60)$ & $0(0,0)$ & $5,62(7,55)$ & $9,02(7,31)$ & 0,002 \\
\hline Reconsulta/re & in tras el alta desde Urgencias & $61(17,6)$ & $2(0,6)$ & $48(16,4)$ & $13(24,1)$ & 0,028 \\
\hline
\end{tabular}




\begin{tabular}{|c|c|c|c|c|c|c|}
\hline \multirow[t]{4}{*}{ Tabla 1} & \multicolumn{6}{|c|}{$\begin{array}{l}\text { Características clínico-epidemiológicas, de comorbilidad, de evolución } \\
\text { y analíticas estudiadas en la primera valoración del paciente en el SUH } \\
\text { (análisis univariable) (cont.) }\end{array}$} \\
\hline & & Total & Valores & Supervivientes & Fallecidos & Valor $p$ \\
\hline & & $n=347$ & perdidos & a 30 dias & a 30 días & \\
\hline & & $(\%)$ & $n(\%)$ & $n=293(84,4 \%)$ & $n=54(15,6 \%)$ & \\
\hline \multicolumn{7}{|c|}{ HALLAZGOS ANALITICOS Y MICROBIOLÓGICOS } \\
\hline \multicolumn{2}{|c|}{ Bacteriemia verdadera $\mathrm{n}(\%)$} & $52(15,0)$ & $0(0,0)$ & $31(10,6)$ & $21(38,9)$ & $<0,001$ \\
\hline \multicolumn{2}{|c|}{ Creatinina $\geq 2 \mathrm{mg} / \mathrm{dl} \mathrm{n}(\%)$} & $39(11,2)$ & $0(0,0)$ & $26(8,9)$ & $13(24,1)$ & 0,003 \\
\hline \multicolumn{2}{|c|}{ Leucocitos por $\mathrm{mm}^{3}$ [media (DE)] } & $15.206(12.347)$ & $0(0,0)$ & $14.807(12.467)$ & $17.370(11.541)$ & 0,143 \\
\hline \multicolumn{2}{|c|}{ Leucocitosis > 12.000/ mm ${ }^{3}$} & $197(56,8)$ & $0(0,0)$ & $158(53,9)$ & $39(72,2)$ & 0,009 \\
\hline \multicolumn{2}{|c|}{ Leucocitos $<4.000 / \mathrm{mm}^{3}$} & $12(3,5)$ & $0(0,0)$ & $10(3,4)$ & $2(3,7)$ & 0,582 \\
\hline \multicolumn{2}{|c|}{ Cayados (bandas) > 10\% } & $46(13,3)$ & $10(2,9)$ & $38(13,0)$ & $8(14,8)$ & 0,354 \\
\hline \multicolumn{2}{|c|}{ Plaquetas por $\mathrm{mm}^{3}$ [media (DE)] } & $222.300(102.799)$ & $0(0,0)$ & $221.570(103.827)$ & $226.260(97.864)$ & 0,759 \\
\hline \multicolumn{2}{|c|}{ Trombopenia $<150.000 / \mathrm{mm}^{3}$} & $67(19,3)$ & $0(0,0)$ & $53(18,1)$ & $14(25,9)$ & 0,126 \\
\hline \multicolumn{2}{|c|}{ Lactato sérico en mmol// ([media (DE)] } & $1,94(1,15)$ & $0(0,0)$ & $1,75(0,85)$ & $3,05(1,82)$ & $<0,001$ \\
\hline \multicolumn{2}{|c|}{ Lactato $\geq 2 \mathrm{mmol} / \mathrm{L}, \mathrm{n}(\%)$} & $112(32,3)$ & $31(8,9)$ & $81(27,6)$ & $31(57,4)$ & $<0,001$ \\
\hline \multicolumn{2}{|c|}{ Lactato $\geq 4 \mathrm{mmol} / \mathrm{L}, \mathrm{n}(\%)$} & $16(4,6)$ & $31(8,9)$ & $5(1,7)$ & $11(20,4)$ & $<0,001$ \\
\hline \multicolumn{2}{|c|}{ Proteína $C$ reactiva en mg/L [media (DE)] } & $27,20(42,98)$ & $0(0,0)$ & $24,54(39,73)$ & $41,61(55,78)$ & 0,007 \\
\hline \multicolumn{2}{|c|}{ Proteina C reactiva $\geq 9 \mathrm{mg} / \mathrm{l}$} & $215(62,0)$ & $0(0,0)$ & $168(57,3)$ & $47(87,0)$ & $<0,001$ \\
\hline \multicolumn{2}{|c|}{ Proteina $C$ reactiva $\geq 21 \mathrm{mg} / \mathrm{l}$} & $113(32,6)$ & $0(0,0)$ & $83(28,3)$ & $30(55,6)$ & $<0,001$ \\
\hline \multicolumn{2}{|c|}{ Procalcitonina en ng/ml [media (DE)] } & $2,25(7,84)$ & $0(0,0)$ & $1,36(4,24)$ & $7,09(16,56)$ & $<0,001$ \\
\hline \multicolumn{2}{|c|}{ Procalcitonina $\geq 0,5 \mathrm{ng} / \mathrm{ml}, \mathrm{n}(\%)$} & $99(28,5)$ & $0(0,0)$ & $63(21,5)$ & $36(66,7)$ & $<0,001$ \\
\hline \multicolumn{2}{|c|}{ Procalcitonina $\geq 1 \mathrm{ng} / \mathrm{ml}, \mathrm{n}(\%)$} & $76(21,9)$ & $0(0,0)$ & $46(15,7)$ & $30(55,6)$ & $<0,001$ \\
\hline \multicolumn{2}{|c|}{ Procalcitonina $\geq 10 \mathrm{ng} / \mathrm{ml}, \mathrm{n}(\%)$} & $24(6,9)$ & $0(0,0)$ & $13(4,4)$ & $11(20,4)$ & $<0,001$ \\
\hline \multicolumn{2}{|c|}{ suPAR en ng/ml [media (DE)] } & $7,21(3,94)$ & $0(0,0)$ & $6,34(3,20)$ & $11,94(4,21)$ & $<0,001$ \\
\hline \multicolumn{2}{|c|}{ suPAR < $4 \mathrm{ng} / \mathrm{ml}, \mathrm{n}(\%)$} & $74(21,3)$ & $0(0,0)$ & $71(24,2)$ & $3(5,6)$ & $<0,001$ \\
\hline \multicolumn{2}{|c|}{ suPAR 4-6 ng/ml, n (\%) } & $95(27,4)$ & $0(0,0)$ & $90(30,7)$ & $5(9,3)$ & $<0,001$ \\
\hline \multicolumn{2}{|c|}{ suPAR > $6 \mathrm{ng} / \mathrm{ml}, \mathrm{n}(\%)$} & $178(51,3)$ & $0(0,0)$ & $132(45,1)$ & $46(85,2)$ & $<0,001$ \\
\hline \multicolumn{2}{|c|}{ suPAR > $10 \mathrm{ng} / \mathrm{ml}, \mathrm{n}(\%)$} & $78(22,5)$ & $0(0,0)$ & $40(13,7)$ & $38(70,4)$ & $<0,001$ \\
\hline
\end{tabular}

SUH: servicio de urgencias hospitalario; DE: desviación estándar; n: número de casos; $\mathrm{AB}$ : antibióticos; C: centígrados; FC: frecuencia cardiaca; Ipm: latidos por minuto; FR: frecuencia respiratoria; rpm: respiraciones por minuto; máx: máximo; ECG: escala del coma de Glasgow; PAS: presión arterial sistólica; SRIS: síndrome de respuesta inflamatoria sistémica; qSOFA: quick Sepsis-related Organ Failure Assessment; suPAR: receptor soluble del activador del plasminógeno de tipo uroquinasa.

á́ndice de Charlson: ponderado por la edad [26]

Criterios de sepsis (SRIS $\geq 2$ ) según conferencia de Consenso de 2001 [7]

Criterios de sepsis (qSOFA $\geq 2$ ) según la tercera conferencia de consenso (Sepsis-3) [8]

La eficacia para la predicción de mortalidad a los 30 días de los distintos BM y criterios de definición de sepsis se estudió mediante el análisis de las curvas receiver operating characteristic (ROC) con el IC 95\% del área bajo la curva (ABC) de la curva ROC y se comparó frente al valor neutro $(0,5)$. Los errores estándar de las $\mathrm{ABC}$ se calcularon por métodos no paramétricos.

Para completar el estudio de la capacidad predictiva de mortalidad a los 30 dias se elaboró una nueva variable (predictor cuantitativo que se diseñó con un modelo de ajuste por regresión logistica) resultante de la asociación del mejor resultado encontrado con un BM (en este caso de suPAR $>10$ $\mathrm{ng} / \mathrm{ml}$ ) y el qSOFA $\geq 2$. Las probabilidades asi calculadas fueron sometidas a un análisis de curvas ROC y a los mismos procedimientos que los marcadores individuales. Posteriormente, se validó internamente el resultado obtenido mediante un análisis de remuestreo (bootstrapping) con 1.000 remuestreos y se calculó el ABC-COR y su IC 95\%.

Se determinaron los puntos de corte (PC) en los valores de los 


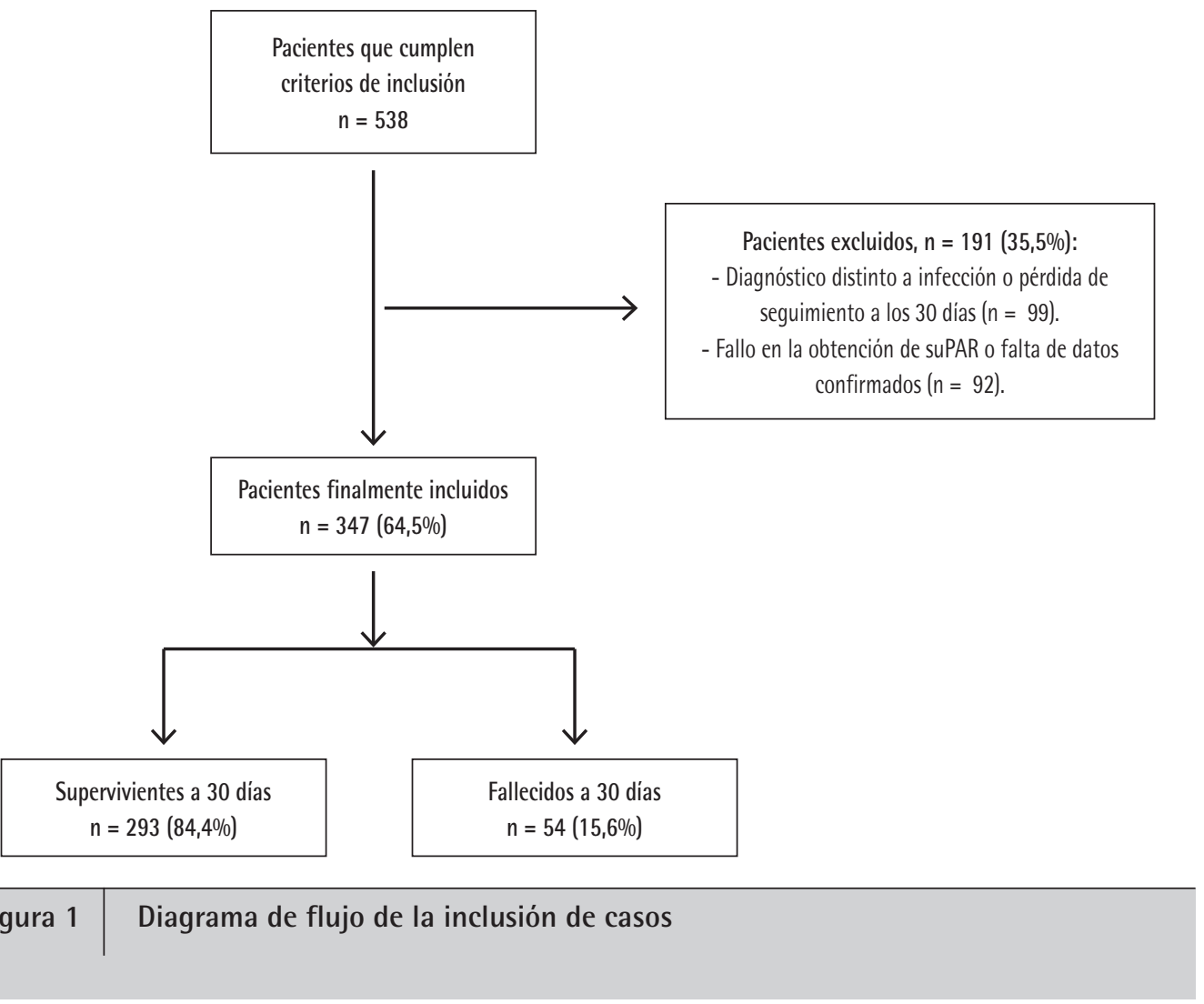

\begin{tabular}{l|ccc}
\hline Tabla 2 & \multicolumn{4}{|l}{$\begin{array}{l}\text { Posibles focos/diagnóstico clínico en el servicio de } \\
\text { urgencias basado en la existencia de mortalidad o no a los } \\
30 \text { dias. }\end{array}$} & $\begin{array}{c}\text { Total } \\
\mathrm{N}=347\end{array}$ & $\begin{array}{c}\text { Supervivientes } \\
\text { a } 30 \text { dias } \\
\mathrm{n}(\%)\end{array}$ & $\begin{array}{c}\text { Fallecidos } \\
\text { a } 30 \text { dias }\end{array}$ \\
\hline Foco/diagnóstico clínico & $184,4 \%)$ & $\mathrm{n}=54(15,6 \%)$ \\
\hline Infección respiratoria & $163(47,0)$ & $139(47,4)$ & $24(44,4)$ \\
\hline Infección del tracto Urinario & $98(28,2)$ & $80(27,3)$ & $18(33,3)$ \\
\hline Infección abdominal & $34(9,8)$ & $28(9,6)$ & $6(11.1)$ \\
\hline Fiebre de origen desconocido & $19(5,5)$ & $18(6,1)$ & $1(1,9)$ \\
\hline Infección de piel y partes blandas & $14(4,0)$ & $10(3,4)$ & $4(7,4)$ \\
\hline Infección del sistema nervioso central & $2(0,6)$ & $2(0,7)$ & $0(0,0)$ \\
\hline Otros focos & $17(4,9)$ & $16(5,4)$ & $1(1,9)$ \\
\hline
\end{tabular}

a Otorrinolaringológico, sospecha de endocarditis, infección de dispositivos vasculares, etc.

BM con mayor capacidad diagnóstica que maximizaba la diferencia entre la tasa de verdaderos positivos y falsos positivos mediante el índice de Youden. Se halló la sensibilidad (S), la especificidad (E), el valor predictivo positivo (VPP) y el valor predictivo negativo (VPN), el coeficiente de probabilidad positivo (CP+) y negativo (CP) para cada resultado estudiado, así como sus IC 95\% por métodos binomiales exactos y por el de Taylor para los CP.
El análisis estadístico se realizó con los programas IBMSPSS $^{\circledast}$ Statistics 22 para Windows y STATA 12.0

Consideraciones éticas. El estudio ha seguido todos los protocolos y normas de nuestro centro e internacionales (Declaración de Helsinki) para la utilización de los datos de los pacientes que se codificaron para asegurar la confidencialidad de los mismos. Se revisó la historia clínica informatizada y de 


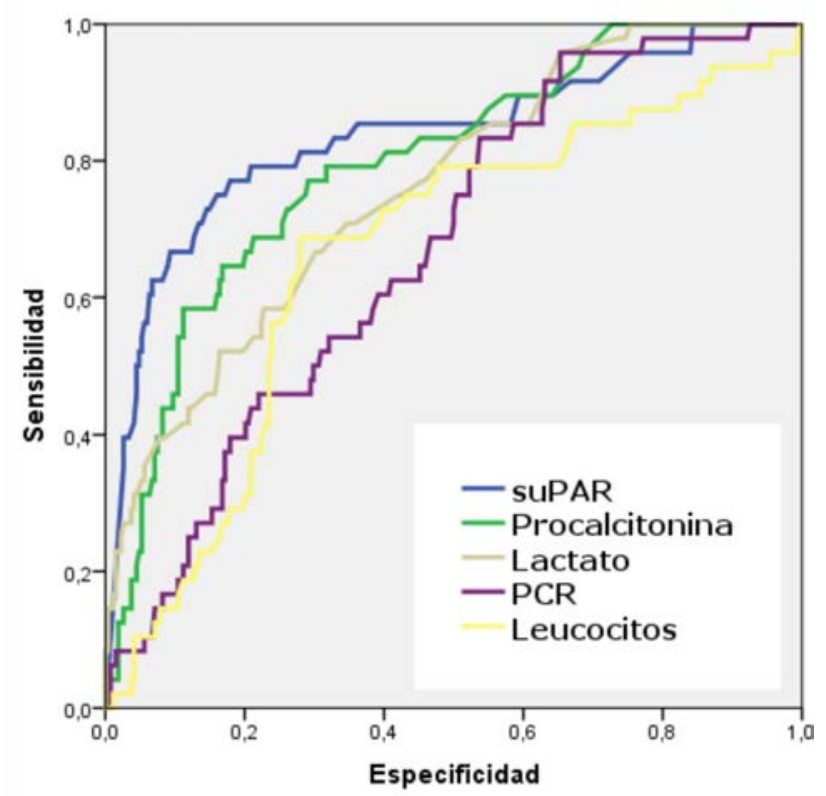

\begin{tabular}{lcc}
\hline & ABC-ROC (IC 95\%) & Valor de p \\
\hline suPAR $(\mathrm{ng} / \mathrm{ml})$ & $0,836(0,765-0,907)$ & $<0,001$ \\
Procalcitonina $(\mathrm{ng} / \mathrm{ml})$ & $0,795(0,728-0,862)$ & $<0,001$ \\
Lactato $(\mathrm{mmol} / \mathrm{L})$ & $0,760(0,689-0,832)$ & $<0,001$ \\
PCR $(\mathrm{mg} / \mathrm{L})$ & $0,671(0,597-0,746)$ & $<0,001$ \\
Leucocitos $\left(\mathrm{mm}^{3}\right)$ & $0,662(0,577-0,747)$ & $<0,001$ \\
\hline
\end{tabular}

Figura 2 Capacidad predictiva de mortalidad a los 30 días de los biomarcadores en pacientes atendidos en el servicio de urgencias por infección

El valor de $p$ indica el riesgo de error tipo $i$ en el contraste de la hipótesis nula de que el ABC-ROC es igual a 0,5.

ABC-ROC: área bajo la curva receiver operating characteristic; IC 95\%: intervalo de confianza del 95\%; PCR: proteína C reactiva; suPAR: receptor soluble del activador del plasminógeno de tipo uroquinasa

atención primaria cuando se requirió. El estudio fue aprobado por el Comité Ético de Investigación Clínica del Hospital Universitario de Toledo ( $\left.n^{0}: 564 / 2020\right)$. Se informó oralmente y por escrito al paciente o sus familiares y se solicitó consentimiento informado previo a la inclusión. El estudio no supuso ninguna intervención terapéutica ni tuvo ninguna implicación clínica.

\section{RESULTADOS}

Durante el periodo de estudio se atendieron en el SUH a 89.759 pacientes de los que se seleccionaron por oportunidad 538 que cumplian con los criterios de inclusión inicialmente. De estos, se excluyeron 191 (35,5\%) por perderse en el seguimiento de 30 dias o bien por cambiar o añadir otro diagnóstico distinto a un proceso infeccioso, o bien, por no obtenerse adecuadamente y de forma validada el resultado de suPAR. Finalmente, se incluyeron 347 pacientes que a los 30 dias mantuvieron como diagnóstico el proceso infeccioso que se había sospechado en el SUH al inicio (Figura 1). De éstos, 56 pacientes $(15,6 \%)$ fallecieron durante los 30 días posteriores a su consulta en el SUH. La edad media fue 66,8 años (DE: 20,30), el 53,6\% eran varones.

Las características demográficas, epidemiológicas, de comorbilidad, datos clínicos (signos y sintomas) y de gravedad, de destino y evolución durante 30 dias, asi como las pruebas analíticas y microbiológicas se muestran en la Tabla 1. Se encontraron diferencias significativas al comparar los pacientes que fallecieron con el resto en las siguientes variables: edad, estar institucionalizado, indice de Charlson, frecuencia cardiaca (FC) $>90 \mathrm{lpm}$, frecuencia respiratoria (FR), alteración del nivel de consciencia, PAS $<100 \mathrm{mmHg}$, qSOFA $\geq 2$, criterios de shock séptico (sepsis-3), confirmación de bacteriemia verdadera, creatinina $\geq 2 \mathrm{mg} / \mathrm{dl}$, leucocitosis $>12.000 / \mathrm{mm}^{3}$, lactacidemia (y dicotomizado para $\geq 2$ y $\geq 4 \mathrm{mmol} / \mathrm{L}$ ), PCR (y dicotomizado para $\geq 9 \mathrm{y} \geq 21 \mathrm{mg} / \mathrm{L}$ ), PCT (y dicotomizado para $\geq 0,5, \geq 1 \mathrm{y} \geq 10 \mathrm{ng} /$ $\mathrm{ml}$ ) y suPAR (y dicotomizado para $<4,>6$ y $>10 \mathrm{ng} / \mathrm{ml}$ ).

El posible foco $u$ origen clínico de presunción en el SUH en relación a los pacientes fallecidos y supervivientes a los 30 dias se muestra en la Tabla 2.

En la Figura 2 se describen los valores de ABC-COR del recuento de leucocitos y los BM estudiados (PCR, PCT, lactato y suPAR) para la capacidad de predicción de mortalidad a los 30 dias de los pacientes atendidos en el SUH por un proceso infeccioso. Los mejores resultados por orden de rendimiento los obtienen suPAR, PCT y lactato. El ABC-COR que consigue suPAR es de 0,836 (IC 95\%: 0,765-0,907) y el PC elegido con mayor capacidad predictiva es $\geq 10 \mathrm{ng} / \mathrm{ml}$ que consigue una $\mathrm{S}$ del $70 \%$, E de $86 \%$ y un VPN del 94\%. En la Tabla 3 se pueden consultar todos los valores de rendimiento diagnóstico de los PC elegidos para suPAR, asi como para el lactato, la PCT, el qSOFA y el modelo de combinación ( $q S O F A \geq 2$ con suPAR $>10 \mathrm{ng} / \mathrm{ml}$ ).

En la Figura 3 se describen los valores de ABC-COR de los criterios de sepsis clásicos (sepsis-1: $S R I S \geq 2$ criterios) y del tercer consenso (sepsis-3) para la capacidad de predicción de mortalidad a los 30 dias. Los criterios clásicos (SRIS $\geq 2$ ) no consiguen 


\begin{tabular}{|c|c|c|c|c|c|c|}
\hline \multirow[t]{2}{*}{ Tabla 3} & \multirow[b]{2}{*}{$\begin{array}{l}\text { Sensibilidad \% } \\
\text { (IC 95\%) }\end{array}$} & \multirow[b]{2}{*}{$\begin{array}{l}\text { Especificidad \% } \\
\text { (IC 95\%) }\end{array}$} & \multirow[b]{2}{*}{$\begin{array}{l}\text { VPP \% } \\
\text { (IC 95\%) }\end{array}$} & \multirow[b]{2}{*}{$\begin{array}{l}\text { VPN \% } \\
\text { (IC 95\%) }\end{array}$} & \multirow{3}{*}{$\begin{array}{c}\begin{array}{c}\mathrm{CP}+ \\
(\mathrm{IC} 95 \%)\end{array} \\
2,14 \\
(1,62-2,82)\end{array}$} & \multirow{3}{*}{$\begin{array}{c}\begin{array}{c}\text { CP- } \\
\text { (IC 95\%) }\end{array} \\
0,51 \\
(0,34-0,75)\end{array}$} \\
\hline & & & & & & \\
\hline Lactato $\geq 2 \mathrm{mmol} / \mathrm{L}$ & $\begin{array}{c}65 \\
(51-78)\end{array}$ & $\begin{array}{c}70 \\
(64-75)\end{array}$ & $\begin{array}{c}28 \\
(20-37)\end{array}$ & $\begin{array}{c}92 \\
(87-95)\end{array}$ & & \\
\hline Lactato $\geq 4 \mathrm{mmol} / \mathrm{L}$ & $\begin{array}{c}23 \\
(13-38)\end{array}$ & $\begin{array}{c}98 \\
(95-99)\end{array}$ & $\begin{array}{c}69 \\
(42-89)\end{array}$ & $\begin{array}{c}88 \\
(83-91)\end{array}$ & $\begin{array}{c}12,28 \\
(4,47-33,78)\end{array}$ & $\begin{array}{c}0,79 \\
(0,67-0,92)\end{array}$ \\
\hline $\mathrm{PCT} \geq 0,5 \mathrm{ng} / \mathrm{m}$ & $\begin{array}{c}67 \\
(52-79)\end{array}$ & $\begin{array}{c}78 \\
(73-83)\end{array}$ & $\begin{array}{c}36 \\
(27-47)\end{array}$ & $\begin{array}{c}93 \\
(89-96)\end{array}$ & $\begin{array}{c}3,10 \\
(2,32-4,14)\end{array}$ & $\begin{array}{c}0,42 \\
(0,29-0,62)\end{array}$ \\
\hline $\mathrm{PCT} \geq 1 \mathrm{ng} / \mathrm{ml}$ & $\begin{array}{c}56 \\
(41-69)\end{array}$ & $\begin{array}{c}84 \\
(80-88)\end{array}$ & $\begin{array}{c}39 \\
(29-51)\end{array}$ & $\begin{array}{c}91 \\
(87-94)\end{array}$ & $\begin{array}{c}3,54 \\
(2,48-5,06)\end{array}$ & $\begin{array}{c}0,53 \\
(0,39-0,71)\end{array}$ \\
\hline $\mathrm{PCT} \geq 10 \mathrm{ng} / \mathrm{m}$ & $\begin{array}{c}20 \\
(11-34)\end{array}$ & $\begin{array}{c}96 \\
(92-98)\end{array}$ & $\begin{array}{c}46 \\
(26-67)\end{array}$ & $\begin{array}{c}87 \\
(82-90)\end{array}$ & $\begin{array}{c}4,59 \\
(2,17-9,71)\end{array}$ & $\begin{array}{c}0,83 \\
(0,73-0,96)\end{array}$ \\
\hline suPAR $>6 \mathrm{ng} / \mathrm{ml}$ & $\begin{array}{c}85 \\
(72-93)\end{array}$ & $\begin{array}{c}56 \\
(49-61)\end{array}$ & $\begin{array}{c}26 \\
(20-33)\end{array}$ & $\begin{array}{c}95 \\
(91-98)\end{array}$ & $\begin{array}{c}1,89 \\
(1,60-2,24)\end{array}$ & $\begin{array}{c}0,27 \\
(0,14-0,52)\end{array}$ \\
\hline suPAR $>8 \mathrm{ng} / \mathrm{ml}$ & $\begin{array}{c}80 \\
(66-89)\end{array}$ & $\begin{array}{c}75 \\
(69-80)\end{array}$ & $\begin{array}{c}37 \\
(28-46)\end{array}$ & $\begin{array}{c}95 \\
(91-97)\end{array}$ & $\begin{array}{c}3,15 \\
(2,48-4,00)\end{array}$ & $\begin{array}{c}0,27 \\
(0,16-0,46)\end{array}$ \\
\hline suPAR $>10 \mathrm{ng} / \mathrm{ml}$ & $\begin{array}{c}70 \\
(56-82)\end{array}$ & $\begin{array}{c}86 \\
(82-90)\end{array}$ & $\begin{array}{c}49 \\
(37-60)\end{array}$ & $\begin{array}{c}94 \\
(90-96)\end{array}$ & $\begin{array}{c}5,15 \\
(3,68-7,21)\end{array}$ & $\begin{array}{c}0,34 \\
(0,23-0,52)\end{array}$ \\
\hline suPAR $>12 \mathrm{ng} / \mathrm{ml}$ & $\begin{array}{c}52 \\
(38-65)\end{array}$ & $\begin{array}{c}95 \\
(92-97)\end{array}$ & $\begin{array}{c}65 \\
(49-79)\end{array}$ & $\begin{array}{c}91 \\
(88-94)\end{array}$ & $\begin{array}{c}10,13 \\
(5,81-17,66)\end{array}$ & $\begin{array}{c}0,51 \\
(0,38-0,67)\end{array}$ \\
\hline$q S O F A \geq 2$ & $\begin{array}{c}53 \\
(39-66)\end{array}$ & $\begin{array}{c}89 \\
(84-92)\end{array}$ & $\begin{array}{c}46 \\
(33-59)\end{array}$ & $\begin{array}{c}91 \\
(87-94)\end{array}$ & $\begin{array}{c}4,64 \\
(3,08-6,99)\end{array}$ & $\begin{array}{c}0,53 \\
(0,40-0,71)\end{array}$ \\
\hline suPAR $>10 \mathrm{ng} / \mathrm{ml}+q \mathrm{SOFA} \geq 2$ & $\begin{array}{c}39 \\
(26-53)\end{array}$ & $\begin{array}{c}97 \\
(95-99)\end{array}$ & $\begin{array}{c}78 \\
(57-91)\end{array}$ & $\begin{array}{c}90 \\
(86-93)\end{array}$ & $\begin{array}{c}18,99 \\
(8,04-44,86)\end{array}$ & $\begin{array}{c}0,62 \\
(0,50-0,77)\end{array}$ \\
\hline
\end{tabular}

IC: intervalo de confianza; VPP: valor predictivo positivo; VPN: valor predictivo negativo; $\mathrm{CP}+$ : cociente de probabilidad positivo; CP-: cociente de probabilidad negativo; suPAR: receptor soluble del activador del plasminógeno de tipo uroquinasa; PCT: procalcitonina; qSOFA: quick Sepsis-related Organ Failure Assessment (qSOFA $\geq 2$ criterios de sepsis según la tercera conferencia de consenso de sepsis [8].

un rendimiento predictivo. Por su parte, qSOFA $\geq 2$ consigue un buen rendimiento con un ABC-COR de 0,707 (IC 95\%: 0,6210,793 ) y una $\mathrm{S}$ de $53 \%$, E de $89 \%$ y VPN de $91 \%$ (Tabla 3 ).

Finalmente, en la Figura 4 se muestra el rendimiento predictivo de mortalidad a los 30 días del nuevo predictor, modelo combinado qSOFA $\geq 2$ con suPAR $\geq 10 \mathrm{ng} / \mathrm{ml}$, en pacientes atendidos en el SUH por un proceso infeccioso, que mejora el conseguido de forma individual tanto por suPAR como por el qSOFA en solitario. Este nuevo modelo ofrece el mejor rendimiento predictivo de mortalidad superior al conseguido por cualquier PC de los BM estudiados y por los criterios de sepsis-1 y sepsis-3. Asi, consigue un ABC-COR de 0,853 (IC 95\%: 0,790-0,916, $p<0,001$ ), con una baja sensibilidad (39\%), pero una muy elevada especificidad (97\%) con un VPN del 90\%. La validación interna, mediante la técnica del remuestreo (bootstrapping) de este nuevo modelo fue de 0,834 (IC 95\%: 0,774-0,894).

En la Tabla 3 se encuentran todos los resultados de rendimiento pronóstico de mortalidad de los PC de los BM estudiados y los criterios de sepsis.
En la Tabla 4 se muestran distintos resultados en relación con la evolución, destino y pronóstico de los pacientes según tres grupos de pacientes elaborados según las concentraciones de suPAR obtenidas: bajo riesgo $(<4 \mathrm{ng} / \mathrm{ml})$, moderado riesgo $(4-6 \mathrm{ng} / \mathrm{ml})$ y alto riesgo $(>6 \mathrm{ng} / \mathrm{ml})$.

\section{DISCUSIÓN}

Los resultados del presente estudio nos permiten confirmar la gran capacidad predictiva de riesgo de mortalidad que ofrecen algunos BM para los pacientes atendidos en los SUH por procesos infecciosos [2,3,12-15]. En concreto, suPAR [1625], que se presenta como el BM que obtiene el mejor rendimiento pronóstico de mortalidad a corto plazo (30 días) de forma individual. Este hecho ya habia sido señalado por otros autores para los pacientes adultos $[17,18]$, aunque con menor rendimiento para los mayores de 75 años en los que el punto de corte debería ser revisado al alza $[10,17,21,23]$. Asimismo, muestra la superioridad del qSOFA $\geq 2$ (sepsis-3) frente a los criterios clásicos de sepsis-1 (SRIS $\geq 2$ ) para predecir el falleci- 


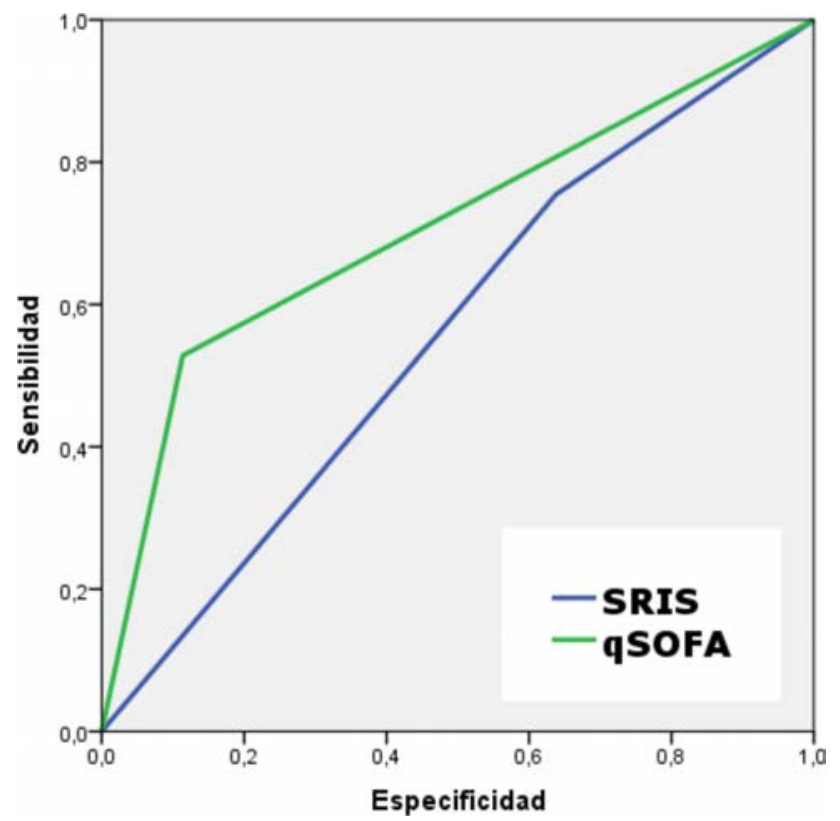

\begin{tabular}{lll}
\hline & ABC-ROC (IC 95\%) & Valor de $p$ \\
\hline SRIS $\geq 2$ & $0,558(0,477-0,640)$ & 0,176 \\
qSOFA $\geq 2$ & $0,707(0,621-0,793)$ & $<0,001$ \\
\hline
\end{tabular}

Figura 3 Capacidad predictiva de mortalidad a los 30 días de los criterios de definición de sepsis clásicos ( $S R I S \geq 2$ ) y del tercer consenso ( $q S O F A \geq 2$ ) en pacientes atendidos en el servicio de urgencias por infección

El valor de $p$ indica el riesgo de error tipo i en el contraste de la hipótesis nula de que el ABC-ROC es igual a 0,5.

ABC-ROC: área bajo la curva receiver operating characteristic; IC 95\%: intervalo de confianza del 95\%;

qSOFA: quick Sepsis-related Organ Failure Assessment (qSOFA $\geq 2$ 2), criterios de sepsis según la tercera conferencia de consenso de sepsis; Singer et al.[8]); SRIS: síndrome de respuesta inflamatoria sistémica ( $\geq 2$ criterios de sepsis según la conferencia de consenso de 2001; Levy et al. [7]).

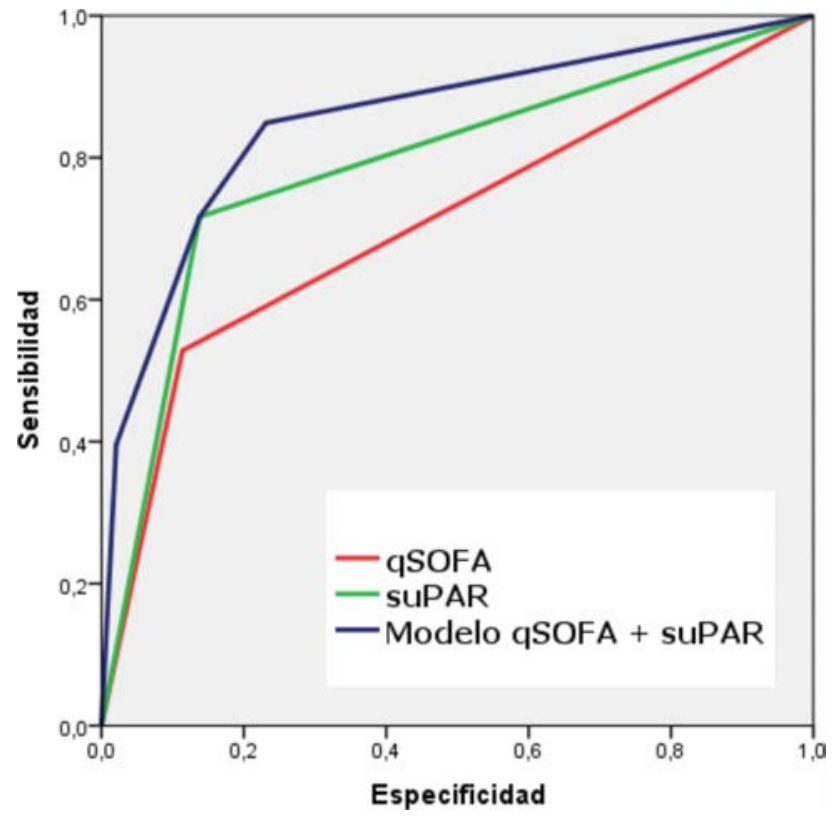

\begin{tabular}{lcc}
\hline & ABC-ROC (IC 95\%) & Valor de $p$ \\
\hline suPAR $>10 \mathrm{ng} / \mathrm{ml}$ & $0,790(0,715-0,864)$ & $<0,001$ \\
qSOFA $\geq 2$ & $0,707(0,621-0,793)$ & $<0,001$ \\
qSOFA $\geq 2+$ suPAR $>10 \mathrm{ng} / \mathrm{ml}$ & $0,853(0,790-0,916)$ & $<0,001$ \\
\hline
\end{tabular}

Figura $4 \quad$ Capacidad predictiva de mortalidad a los 30 días del modelo combinado qSOFA $\geq 2$ y suPAR $>10$ en pacientes atendidos en el servicio de urgencias por infección.

El valor de $p$ indica el riesgo de error tipo $i$ en el contraste de la hipótesis nula de que el ABC-ROC es igual a 0,5.

ABC-ROC: área bajo la curva receiver operating characteristic; IC 95\%: intervalo de confianza del 95\%;

suPAR: receptor soluble del activador del plasminógeno de tipo uroquinasa (punto de corte $>10 \mathrm{ng} / \mathrm{ml}$ );

qSOFA: quick Sepsis-related Organ Failure Assessment (qSOFA 2 criterios de sepsis según la tercera conferencia de consenso de sepsis; Singer et al. [8]). 


\begin{tabular}{|c|c|c|c|c|c|c|}
\hline \multirow[t]{2}{*}{ Tabla 4} & \multicolumn{6}{|c|}{$\begin{array}{l}\text { Resultados de evolución y pronóstico de grupos de pacientes según concentraciones de } \\
\text { suPAR establecidas }\end{array}$} \\
\hline & & $\begin{array}{c}\text { Todos } \\
n=347(\%)\end{array}$ & $\begin{array}{l}\text { suPAR }<4 \mathrm{ng} / \mathrm{ml} \\
\qquad \mathrm{n}=74(\%)\end{array}$ & $\begin{array}{l}\text { suPAR } 4-6 \mathrm{ng} / \mathrm{ml} \\
\qquad \mathrm{n}=95(\%)\end{array}$ & $\begin{array}{l}\text { suPAR }>6 \mathrm{ng} / \mathrm{ml} \\
\mathrm{n}=178(\%)\end{array}$ & $\begin{array}{l}\text { suPAR }>10 \mathrm{ng} / \mathrm{ml} \\
\qquad \mathrm{n}=78(\%)\end{array}$ \\
\hline \multicolumn{2}{|c|}{ Dias de hospitalización: Media (DE) } & $6,15(7,60)$ & $0,74(1,85)$ & $2,80(2,56)$ & $10,19(8,57)$ & $12,54(14,56)$ \\
\hline \multicolumn{2}{|c|}{ Alta directa desde Urgencias } & $92(26,5 \%)$ & $50(67,6 \%)$ & $26(27,4 \%)$ & $16(9,0 \%)$ & $2(2,6 \%)$ \\
\hline \multicolumn{2}{|l|}{ Observación } & $36(10,4 \%)$ & $13(17,6 \%)$ & $20(21,1 \%)$ & $3(1,7 \%)$ & $0(0,0 \%)$ \\
\hline \multicolumn{2}{|c|}{ Unidad de corta estancia } & $18(5,2 \%)$ & $2(2,7 \%)$ & $11(11,6 \%)$ & $5(2,8 \%)$ & $1(1,3 \%)$ \\
\hline \multicolumn{2}{|c|}{ Hospitalización } & $179(52,5 \%)$ & $8(10,8 \%)$ & $37(39,0 \%)$ & $134(75,5 \%)$ & $56(71,7 \%)$ \\
\hline \multicolumn{2}{|c|}{ Unidad de cuidados intensivos } & $22(6,3 \%)$ & $1(1,4 \%)$ & $1(1,1 \%)$ & $20(11,2 \%)$ & $19(24,4 \%)$ \\
\hline \multicolumn{2}{|c|}{ Mortalidad 30 dias } & $54(15,6 \%)$ & $3(4,1 \%)$ & $5(5,3 \%)$ & $46(25,8 \%)$ & $38(48,7 \%)$ \\
\hline \multicolumn{2}{|c|}{ Confirmación bacteriemia } & $52(15 \%)$ & $0(0,0 \%)$ & $2(2,1 \%)$ & $50(28,1 \%)$ & $37(47,4 \%)$ \\
\hline \multicolumn{2}{|c|}{ Reconsulta en 30 dias tras ser dado de alta desde la primera visita } & $61(17,6 \%)$ & $4(5,4 \%)$ & $19(20,0 \%)$ & $38(21,3 \%)$ & $2(2,6 \%)$ \\
\hline
\end{tabular}

DE: desviación estándar; suPAR: receptor soluble del activador del plasminógeno de tipo uroquinasa

miento a los 30 dias, lo que ya se ha comunicado anteriormente en distintas ocasiones para los pacientes adultos valorados en Ios SUH [27-29].

Por ello, según los resultados de nuestro estudio, podemos señalar que tras la primera valoración realizada a los pacientes adultos con infección en el SUH, suPAR y el qSOFA $\geq 2$, respectivamente, son factores independientes relacionados significativamente y con una mayor capacidad pronóstica de mortalidad a corto plazo (30 días). Además, estos dos factores combinados (qSOFA $\geq 2+$ suPAR $>10 \mathrm{ng} / \mathrm{ml}$ ) consiguen el mejor rendimiento pronóstico, por lo que su valoración urgente puede convertirse en una eficaz herramienta de ayuda para orientar las decisiones adecuadas que debe tomar el clínico, como son decidir el alta o ingreso, la obtención de muestras microbiológicas (especialmente los hemocultivos) o la administración inmediata de la terapia antimicrobiana adecuada. Acertar en estas actuaciones urgentes iniciales, sobre todo en los pacientes más graves y vulnerables, será determinante para la evolución del enfermo y su pronóstico vital $[4,30,31]$. Las diferencias entre las ABC-ROC del modelo combinado ( $q S O F A \geq 2+$ suPAR $>10 \mathrm{ng} / \mathrm{ml}$ ) y las de las dos variables de forma individual, respectivamente, resultan significativas. Además, el aumento de especificidad del modelo (97\%), frente al obtenido por qSOFA $\geq 2$ (89\%) y suPAR $>10$ $\mathrm{ng} / \mathrm{ml}$ (86\%), resulta interesante ya que los criterios definitorios de sepsis han sido cuestionados, precisamente, por su baja especificidad $[2,6]$.

En relación con el BM suPAR, es conocida su capacidad para pronosticar el reingreso, evaluar la gravedad y predecir mortalidad (intrahospitalaria, a 30 días y a 90 dias) y su gran rendimiento como herramienta de ayuda en el triaje y clasificación de los pacientes en los SUH [17,19,22,25], incluso en pacientes con COVID-19 [3,18]. Así, por ejemplo Kumar et al [25] recomiendan que los pacientes con concentraciones mayores a $5,5 \mathrm{ng} / \mathrm{ml}$ de suPAR en el triaje se queden ingresados en el hospital y realizar una reevaluación a los tres dias. En este sen- tido se han publicado algoritmos de decisión de alta o ingreso que son recomendados y ya utilizados por distintos autores en la práctica clínica en otros países [32,33], que proponen un PC $<3-4 \mathrm{ng} / \mathrm{ml}$ para decidir el alta del paciente con seguridad, un intervalo de concentración entre 4-6 $\mathrm{ng} / \mathrm{ml}$ que recomendaría que el paciente fuera reevaluado y se mantuviera en observación del SUH, y el PC >6 ng/ml donde el paciente precisaría ingresar en el hospital. Por su parte, cuando las concentraciones de suPAR son $>10-12 \mathrm{ng} / \mathrm{ml}$ el paciente sería candidato a una vigilancia más intensiva dentro del hospital $[23,24,32,33]$. Estas recomendaciones se asemejan a las que podríamos efectuar con nuestros resultados, donde, por ejemplo, la mortalidad a 30 dias encontrada es del 4,1\%, 5,3\%, 25,8\% y 48,7\% según las concentraciones de suPAR $<4 \mathrm{ng} / \mathrm{ml}$, de $4-6 \mathrm{ng} / \mathrm{ml}$, $>6 \mathrm{ng} / \mathrm{ml}$ y $>10 \mathrm{ng} / \mathrm{ml}$, respectivamente. Aunque, como ya se ha publicado, en pacientes ancianos y con gran comorbilidad estos PC podrian ser algo superiores como ocurre con el sexo mujer $[10,17,21,23,33]$. El rendimiento pronóstico de suPAR de mortalidad a los 30 días obtenido en nuestro estudio con un ABC-ROC de 0,836 (IC 95\%: 0,765-0,907) es similar al publicado por autores que utilizan este BM habitualmente en su SUH como herramienta de triaje con un $\mathrm{ABC}$ de 0,84 (IC 95\%: 0,81$0,86)[17]$. Por todo lo dicho anteriormente y valorando que la estancia media de los pacientes también se relaciona con las concentraciones de suPAR obtenidas en el SUH $(0,74$ días si $<4$ $\mathrm{ng} / \mathrm{ml}, 2,80$ dias de 4 a $6 \mathrm{ng} / \mathrm{ml}, 10,19$ dias si $>6 \mathrm{ng} / \mathrm{ml} \mathrm{y,} \mathrm{12,54}$ días si $>10 \mathrm{ng} / \mathrm{ml}$ ), así como con la necesidad de ingreso en medicina intensiva que se cifra en $24,4 \%$ de los pacientes con suPAR> $10 \mathrm{ng} / \mathrm{ml}$, no solo las concentraciones de suPAR van a pronosticar la mortalidad, también pueden resultar útiles para valorar el ingreso en $\mathrm{UCl}$ y planificar el lugar idóneo de ingreso $[23,24,32,33]$.

Por su parte, cabe decir que la PCT, aunque con mayor capacidad que la PCR y el recuento de leucocitos (y muy parecida a la del lactato), aun encontrándose diferencias signifi- 
cativas en el estudio univariable, es claramente inferior para el pronóstico de mortalidad que suPAR $[2,17,34]$. Sin embargo, como es superior a este para detectar infección bacteriana grave y bacteriemia, las últimas revisiones y documentos de consenso recomiendan su utilización conjunta, lo que se ha llamado "sinergia de los BM" $[2,6,12]$. Así, como hemos encontrado nosotros en nuestra muestra, una PCT $\geq 0,5 \mathrm{ng} / \mathrm{ml}$ indicaría una mayor probabilidad de fallecimiento a los 30 dias, de infección bacteriana, de existencia de bacteriemia y, por todo ello, la necesidad de ingreso, al menos en observación del SUH para adecuar y mejorar el tratamiento de los pacientes con infección grave $[12,13,15,35]$.

En cualquier caso, la recomendación de utilizar los BM combinados entre sí (uno con capacidad diagnóstica y otro pronóstica) o con escalas de riesgo o criterios de sepsis (por ejemplo del SRIS o qSOFA) cada vez es más generalizada debido a la disponibilidad de estos en los SUH $[2,3,24,34-36]$.

En relación con el resto de los BM comparados en nuestro estudio, el lactato está incluido en las recomendaciones de valoración de todos los pacientes con sepsis en los SUH $[2,4,8]$. Un lactato sérico $>2 \mathrm{mmol} / \mathrm{l}$ en el SUH se asociaba con un riesgo relativo de mortalidad a los 30 días de 1,7-2,6 por lo que precisará ver su evolución tras las medidas tomadas en el SUH $y$, cuando se confirme un valor $\geq 4 \mathrm{mmol} / \mathrm{l}$ de lactato sérico, el paciente debería ser ingresado [12]. Del mismo modo ocurre en los ancianos atendidos en el SUH por un proceso infeccioso (más del 35\% de las atenciones) $[1,2]$ donde un lactato $>4$ mmol// (con OR 21,14; IC 95\%: 8,94-49,97, $\mathrm{p}=0,001$ ) es el factor que con más peso predice mortalidad, sin necesitar de ser ajustado por la edad [37].

Por otra parte, nuestros resultados confirman que, para los enfermos atendidos por infección en el SUH, tal y como se ha publicado recientemente, los criterios de sepsis clásicos (SRIS $\geq 2$ ) son insuficientes y menos válidos que un qSOFA $\geq 2$ para valorar el pronóstico de estos $[5,27]$. La $S$ del $53 \%$ y la $E$ del 89\% del qSOFA en nuestro estudio son similares a las publicadas recientemente, en las que se ha vuelto a constatar las limitaciones y el margen de mejora que tienen estos criterios para la estratificación del riesgo y pronóstico en los pacientes atendidos en los SUH $[5,27,29,38,39]$.

Nuestro estudio tiene distintas limitaciones. Las principales son, por una parte, el carácter unicéntrico del estudio y, por otra, el haber reclutado los casos por oportunidad (cuando los investigadores estaban de guardia). Por ello, existe la posibilidad de un sesgo de selección al depender la inclusión de los pacientes de la presencia de uno de los investigadores, aunque esta fuera consecutiva durante esos periodos de tiempo, y el que finalmente el $35,5 \%$ de los pacientes incluidos fueran excluidos en los 30 dias de seguimiento.

Por otro lado, no se han analizado las caracteristicas de los pacientes y las diferencias en la mortalidad entre distintos tipos de infección (bacteriana o viral), ya que no era el objetivo del estudio, asumiendo la heterogeneidad de alguno de ellos, como el respiratorio, donde se incluyen infecciones víricas y bacterianas (y mixtas) que podrian explicar las diferencias en- contradas entre ellos. En este sentido la mortalidad global de los pacientes de nuestro estudio es algo superior a la objetivada en otros (posiblemente en relación a la mayor edad de los pacientes y el tipo de foco predominante, en nuestro caso neumonias) $[37,40]$.

Finalmente, como el modelo mixto ha sido generado a partir de los datos de los 347 pacientes del estudio, es necesario que se validen sus resultados con una serie externa.

A pesar de estas limitaciones, creemos que el estudio es un reflejo de la realidad clínica de nuestros SUH y el reflejo del papel que, en un futuro, pueden jugar algunos de los nuevos BM como suPAR. Así, junto a la PCT o el lactado, creemos que puede ser de ayuda y muy rentable al analizar coste-beneficio si tenemos en cuenta que una visita al SUH se valora en $240 €$, una estancia en observación más de $300 €$ y un día de ingreso en más de $400 €$. Además, su coste de $18 €$, es "asumible" si lo comparamos con el de otros BM que se solicitan a la mayoria de los enfermos con el perfil de nuestra muestra (3€ el lactato, 4-5€ la PCR, $10 €$ la PCT, precios comunicados por nuestro centro). A nuestro juicio, este coste no debería ser un obstáculo para su disponibilidad razonada en los SUH.

Como conclusiones de este estudio podemos señalar que para predecir mortalidad a los 30 dias en los pacientes que acuden al SUH por un episodio de infección, suPAR presenta una capacidad pronóstica superior a otros BM, la escala qSOFA obtiene mayor rendimiento que los criterios de SRIS, y el modelo combinado qSOFA $\geq 2$ con suPAR $>10 \mathrm{ng} / \mathrm{ml}$ mejora el poder predictivo conseguido de forma individual por qSOFA, consiguiendo una E del 97\% y un VPN del 90\%. Futuros estudios multicéntricos de validación externa del modelo son necesarios.

\section{AGRADECIMIENTOS} Gates.

Los reactivos para medir suPAR fueron cedidos por Viro-

\section{FINANCIACIÓN}

Los autores declaran no haber recibido financiación para la realización de este estudio.

\section{CONFLICTO DE INTERESES}

Los autores declaran la ausencia de conflictos de intereses en relación con el presente artículo.

AJJ ha participado en reuniones científicas organizadas por Roche, Thermo Scientific Biomarkers, B.R.A.H.M.S. AG, ViroGates y Biomerieux.

\section{BIBLIOGRAFÍA}

1. Martínez Ortiz de Zárate $M$, González del Castillo J, Julián-Jiménez A, Piñera Salmerón P, Llopis Roca F, Guardiola Tey JM. Estudio INFURG-SEMES: Epidemiología de las Infecciones en los Servicios de 
Urgencias Hospitalarios y evolución en la última década. Emergencias. 2013;25:368-78.

2. Julián-Jiménez A, Supino M, López Tapia JD, Ulloa González C, Vargas Téllez $L E$, Juan González del Castillo, et al, en nombre del Grupo de Trabajo Latinoamericano para la mejora de la atención del paciente con Infección en Urgencias (GT-LATINFURG). Puntos clave y controversias sobre la sepsis en los servicios de urgencias: propuestas de mejora para Latinoamérica. Emergencias. 2019;31:123135. PMID: 30963741

3. Julián-Jiménez A, García DE, González del Castillo J, Guimarães HP, García-Lamberechts EJ, Menéndez E, et al, en nombre del Grupo de Trabajo Latinoamericano para la mejora de la atención del paciente con Infección en Urgencias (GT-LATINFURG). Puntos clave sobre la COVID-19 en los servicios de urgencias: propuestas de mejora para su atención en Latinoamérica. Emergencias. 2021;33:42-58. PMID: 33496399

4. Rhodes $A$, Evans $L E$, Alhazzani W, Levy MM, Antonelli M, Ferrer $R$, et al. Surviving Sepsis Campaign: International guidelines for management of sepsis and septic shock: 2016. Crit Care Med. 2017:45:486-552. doi: 10.1097/CCM.0000000000002255

5. Candel FJ, Borges Sa M, Belda S, Bou G, Del Pozo JL, Estrada O, et al. Current aspects in sepsis approach. Turning things around. Rev Esp Quimioter.2018;31:298-315. PMID: 29938972

6. Julián-Jiménez $A$, Supino $M$, Loro Chero $L$, en nombre del Grupo de Trabajo Latinoamericano para la mejora de la atención del paciente con Infección en Urgencias (GT-LATINFURG). Hacia la definición de Sepsis-4: poder diagnóstico y pronóstico de los biomarcadores para mejorar el tratamiento de la sepsis en los servicios de urgencias. Med Clin (Barc). 2020;154:147-8. doi: 10.1016/j. medcli.2019.02.015.

7. Levy MM, Fink MP, Marshall JC, Abraham E, Angus D, Cook D et al. 2001 SCCM/ESICM/ACCP/ATS/SIS International Sepsis Definitions Conference. Crit Care Med. 2003; 31:1250-6. doi: 10.1097/01. CCM.0000050454.01978.3B.

8. Singer M, Deutschman CS, Seymour CW, Shankar-Hari M, Annane

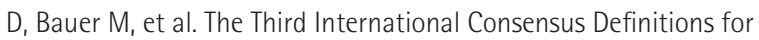
Sepsis and Septic Shock (Sepsis-3). JAMA. 2016;315:801-10. doi: 10.1001/jama.2016.0287.

9. Seymour CW, Liu VX, Iwashyna TJ, Brunkhorst FM, Rea TD, Scherag $A$, et al. Assessment of Clinical Criteria for sepsis: Fort he Third International Consensus Definitions for sepsis and Septic Shock (sepsis-3). JAMA. 2016:315:762-74. doi: 10.1001/jama.2016.0288.

10. Julián-Jiménez $A$, Yañez MC, González del Castillo J, Salido-Mota M, Mora-Ordóñez B, Arranz-Nieto MJ, et al. Poder pronóstico de mortalidad a corto plazo de los biomarcadores en los ancianos atendidos en Urgencias por infección. Enferm Infecc Microbiol Clin. 2019; 37:11-8. doi: 10.1016/j.eimc.2017.11.017.

11.- Vincent JL, Bogossian E, Menozzi M. The Future of Biomarkers. Crit Care Clin. 2020;36:177-87. doi: 10.1016/j.ccc.2019.08.014.

12. Julián-Jiménez A, Candel-González FJ, González del Castillo J. Utilidad de los biomarcadores de inflamación e infección en los servicios de urgencias. Enferm Infecc Microbiol Clin. 2014;32:177-190. doi: 10.1016/j.eimc.2013.01.005.
13. Rubio Díaz R, Nieto Rojas I, Julián-Jiménez A. Importancia de la predicción de bacteriemia en los servicios de urgencias: seis años después. Enferm Infecc Microbiol Clin. 2021;39:102-10. doi: 10.1016/j.eimc.2020.04.006.

14. Julián-Jiménez $A$, Zafar Iqbal-Mirza $S$, De Rafael González E, Estévez-González R, Serrano-Romero de Ávila V, Heredero-Gálvez $\mathrm{E}$, et al. Modelo 5MPB-Toledo para predecir bacteriemia en los pacientes atendidos por infección en el servicio de urgencias. Emergencias 2020;32:81-89. PMID: 32125106

15. Julián-Jiménez A, García-Lamberechts EJ, González del Castillo J, Navarro Bustos C, LLopis-Roca F, Martínez-Ortiz de Zárate M, et al. Validación del modelo predictivo de bacteriemia (5MPB-Toledo) en los pacientes atendidos en el servicio de urgencias por infección. Enferm Infecc Microbiol Clin. 2021. doi: 10.1016/j.eimc.2020.12.007

16. Del Portal DA, Shofer F, Mikkelsen ME, Dorsey PJ, Gaieski DF, Goyal $M$, et al. Emergency department lactate is associated with mortality in older adults admitted with and without infections. Acad Emerg Med. 2010;17:260-8. doi: 10.1111/j.1553-2712.2010.00681.x.

17. Hartmann Rasmussen $\sqcup$, Ladelund $S$, Huneck Haupt $T$, Ellekilde $G$, Hjelm Poulsen J, Iversen $K_{1}$ et al. Soluble urokinase plasminogen activator receptor (suPAR) in acute care: a strong marker of disease presence and severity, readmission and mortality. A retrospective cohort study. Emerg Med J. 2016;33:769-75. doi: 10.1136/emermed-2015-205444

18. Stauning MA, Altintas I, Kallemose T, Eugen-Olsen J, Lindstrøm MB, Hartmann Rasmussen $\sqcup$, et al. Soluble urokinase plasminogen activator receptor as a decision marker for early discharge of patients with COVID-19 symptoms in the emergency department. J Emerg Med. 2021. doi: 10.1016/j.jemermed.2021.03.012.

19. Schultz $M$, Rasmussen $\sqcup H$, Høi-Hansen $T$, Kjøller $E_{1}$ Jensen $B N$, Lind $M N$, et al. Early Discharge from the Emergency Department Based on Soluble Urokinase Plasminogen Activator Receptor (suPAR) Levels: A TRIAGE III Substudy. Dis Markers. 2019;3403549. doi: 10.1155/2019/3403549

20. Ploug M, Eriksen J, Plesner T, Hansen NE, Danø K. A soluble form of the glycolipid-anchored receptor for urokinase-type plasminogen activator is secreted from peripheral blood leukocytes from patients with paroxysmal nocturnal hemoglobinuria. Eur J Biochem. 1992;208:397-404. doi: 10.1111/j.1432-1033.1992.tb17200.x.

21. Enocsson $H$, Wirestam $L$, Dahle $C$, Padyukov $L$, Jönsen $A$, Urowitz $M B$, et al. Soluble urokinase plasminogen activator receptor (su$P A R$ ) levels predict damage accrual in patients with recent-onset systemic lupus erythematosus. J. 2020;106:102340. doi: 10.1016/j. jaut.2019.102340.

22. Schultz $M$, Rasmussen $\sqcup H_{1}$ Andersen $M H$, Stefansson JS, Falkentoft AC, Alstrup $M$, et al. Use of the prognostic biomarker suPAR in the emergency department improves risk stratification but has no effect on mortality: a cluster-randomized clinical trial (TRIAGE III). Scand J Trauma Resusc Emerg Med. 2018;26:69. doi: 10.1186/ s13049-018-0539-5.

23. Rasmussen $\sqcup H$, Ladelund $S$, Haupt $T H$, Ellekilde GE, Eugen-Olsen J, Andersen 0. Combining National Early Warning Score With Soluble Urokinase Plasminogen Activator Receptor (suPAR) Improves Risk Prediction in Acute Medical Patients: A Registry-Based 
R. Rubio Díaz, et al.

Poder pronóstico de mortalidad a corto plazo del receptor soluble activador del plasminógeno tipo

uroquinasa (suPAR) en los pacientes atendidos en urgencias por infección

Cohort Study. Crit Care Med. 2018;46:1961-1968. doi: 10.1097/ CCM.0000000000003441.

24. Ni W, Han $Y$, Zhao J, Cui J, Wang K, Wang R, et al. Serum soluble urokinase-type plasminogen activator receptor as a biological marker of bacterial infection in adults: a systematic review and meta-analysis. Sci Rep. 2016;6:39481. doi: 10.1038/srep39481.

25. Kumar P, Kakar A, Gogia A, Waziri N. Evaluation of soluble urokinase-type plasminogen activator receptor (suPAR) quick test for triage in the emergency department. J Family Med Prim Care. 2019;8:3871-5. doi: 10.4103/jfmpc.jfmpc_116_19.

26. Charlson M, Pompei P, Ales KL, McKenzie CR. A new method of classyfing pronostic comorbidity in longitudinal studies: Development and validation. J Chron Dis. 1987;40:373-83. doi: 10.1016/00219681(87)90171-8.

27. Freund $Y$, Lemachatti $N$, Krastinova $E_{1}$ Van Laer $M$, Claessens $Y E_{1}$ Avondo A, et al; French Society of Emergency Medicine Collaborators Group. Prognosis Accuracy of Sepsis-3 Criteria for In-Hospital Mortality Among Patients With Suspected Infection Presenting to the Emergency Department. JAMA. 2017;317:301-8. doi: 10.1001/ jama.2016.20329.

28. González J, Clemente C, Candel FJ, Martín-Sánchez FJ. New sepsis criteria: Do they replace or complement what is known in the approach to the infectious patient? Rev Esp Quimioter. 2017;30 Suppl 1:48-51. PMID: 28882016

29. Williams JM, Greenslade JH, McKenzie JV, Chu K, Brown AF, Lipman J. Systemic Inflammatory Response Syndrome, Quick Sequential Organ Function Assessment, and Organ Dysfunction: Insights From a Prospective Database of ED Patients With Infection. Chest. 2017;151:586-96. doi: 10.1016/j.chest.2016.10.057.

30. González-Castillo J, Candel FJ, Julián-Jiménez A. Antibióticos y el factor tiempo en la infección en urgencias. Enferm Infecc Microbiol Clin. 2013; 31:173-80. doi: 10.1016/j.eimc.2012.01.025.

31. Leey-Echavarría C, Zorrilla-Riveiro J, Arnau A, Jaén-Martínez $L$, Lladó-Ortiz D, Gene E. Predicción de ingreso hospitalario en los pacientes con bajo nivel de prioridad de triaje atendidos en un servicio de urgencias. Emergencias. 2020;32:395-402. PMID: 33275359

32. Nayak RK, Allingstrup $M$, Phanareth $K$, Kofoed-Enevoldsen A. suPAR as a biomarker for risk of readmission and mortality in the acute medical setting. Dan Med J. 2015;62(10):A5146. PMID: 26441392

33. Huneck Haupt $T H$, Petersen J, Ellekilde G, Hedegaard Klausen $H_{\text {, }}$ Wandall Thorball C, Eugen-Olsen J, et al. Plasma suPAR levels are associated with mortality, admission time, and Charlson Comorbidity Index in the acutely admitted medical patient: a prospective observational study. Crit Care. 2012; 16:R130. doi: 10.1186/ cc11434.

34. Donadello K, Scolletta S, Covajes $C$, Vincent JL. suPAR as a prognostic biomarker in sepsis. BMC Med. 2012;10:2. doi: 10.1186/17417015-10-2.

35. Freund Y, Philippon AL. Pacientes infectados en el servicio de urgencias: ¿qué debemos detectar? Emergencias. 2020;32:75-6. PMID: 32125103

36. Backes Y, van der Sluijs KF, Mackie DP, Tacke F, Koch A, Tenhunen $J$ J, et al. Usefulness of suPAR as a biological marker in patients with systemic inflammation or infection: a systematic review. Intensive Care Med. 2012;38(9):1418-28. doi: 10.1007/s00134-012-2613-1.

37. Julián-Jiménez A, González del Castillo J, Martínez Ortiz de Zárate $M$, Arranz-Nieto MJ, González Martínez F, Piñera Salmerón P, et al. Factores pronósticos a corto plazo en los pacientes ancianos atendidos en urgencias por infección. Enferm Infecc Microbiol Clin. 2017;35:214-9. doi: 10.1016/j.eimc.2015.10.016.

38. Carbó M, Fresco L, Osorio G, Monclús E, Ortega M. Factores predistivos de mortalidad en los pacientes con sepsis y un valor indicador "Quick Sequential Organ Failure Assessment" (qSOFA) de 2 o 3 puntos atendidos en un servicio de urgencias. Emergencias. 2020:32:169-76. PMID: 32395924

39. González del Castillo J, Julián-Jiménez A, González-Martínez F, Álvarez-Manzanares J, Piñera P, Navarro-Bustos C, et al. Prognostic accuracy of SIRS criteria, qSOFA score and GYM score for 30-daymortality in older non-severely dependent infected patients attended in the emergency department. Eur J Clin Microbiol Infect Dis. 2017; 36:2361-9. doi: 10.1007/s10096-017-3068-7.

40. Julián-Jiménez A, González del Castillo J, García-Lamberechts EJ, Rubio Díaz R, Huarte Sanz I, Navarro Bustos C, et al. Utilidad del modelo 5MPB-Toledo para predecir bacteriemia en el paciente con neumonía adquirida en la comunidad en el Servicio de Urgencias. Rev Esp Quimioter 2021;34(4): 376-382. doi:10.37201/ req/043.2021 
José-Luis Puerta'

Macarena Torrego-

Ellacuría ${ }^{2}$

Ángel Del Rey-Mejías ${ }^{2,3}$

César Biénzobas López ${ }^{4}$

\title{
Comorbidities of Primary Care patients with COVID-19 during the first wave of the SARS-CoV-2 pandemic in the Community of Madrid
}

\author{
'Consejería de Sanidad y Dirección General de Estadística, Comunidad de Madrid, Spain \\ ${ }^{2}$ Unidad de Innovación. Instituto de Investigación Sanitaria San Carlos (IDISSC). Hospital Clínico San Carlos. Madrid, \\ Spain. \\ ${ }^{3}$ Departamento de Psicobiología y Metodología en Ciencias del Comportamiento, Facultad de Psicología, Universidad \\ Complutense, Madrid, Spain. \\ ${ }^{4}$ Dirección General de Inspección y Ordenación Sanitaria. Consejería de Sanidad. Madrid, Spain.
}

Article history

Received: 12 August 2021; Revision Requested: 21 September 2021; Revision Received: 7 0ctober 2021; Accepted:28 0ctober 2021; Published: 10 December 2021

\begin{abstract}
Objectives. Recent publications on inpatients with COVID-19 describing their comorbidities and demographic profile exists, but data from large populations requiring only primary care (PC) are scarce. This paper aims to fill this gap and report the prevalence of eight comorbidities (high blood pressure, diabetes mellitus, cancer, cardiovascular disease, asthma, chronic kidney disease, chronic obstructive pulmonary disease, and chronic heart failure) among patients attending PC during the onset of the SARS-CoV-2 pandemic in the Community of Madrid (CoM), Spain.
\end{abstract}

Patients and methods. This is an observational retrospective study that collects data registered in the CoM between February 25th and May 31st, 2020. Data are divided in two groups: Group-1 $(\mathrm{N}=339,890)$ consist of all patients with suspected or proven SARS-CoV-2 infection; and Group-2 is the subgroup ( $N=48,556,14.3 \%$ of Group- 1 ) of individuals with COVID-19 confirmed by positive RT-PCR test.

Results. Comparing Group-1 with Group-2, $339,890 / 48,556$ patients, respectively, the main results were as follows: average age (60.9/69.9 years), presence of at least one comorbidity (33.51\%/47.69\%), high blood pressure $(19.74 \% / 32.74 \%)$, diabetes mellitus $(7.13 \% / 13.75 \%)$, cancer $(6.56 \% / 10.6 \%)$, cardiovascular disease $(4.52 \% / 9.26 \%)$, asthma $(7.98 \% / 6.56 \%)$, chronic kidney disease $(1.84 \% / 4.41 \%)$, chronic obstructive pulmonary disease (2\%/4.03\%), and chronic heart failure (1.14\%/2.77\%). High blood pressure and diabetes mellitus were seen to be the most frequent (6.56\%/8.38\%) association.

Conclusions. Patients requiring PC attention during the

Correspondence:

Dr. José Luis Puerta

Consejeria de Sanidad

Calle de la Aduana, 29

28013 Madrid

E-mail: puerta.lopez-cozar@salud.madrid.org first wave of the COVID-19 pandemic in the CoM presented with a very high rate of comorbidities, with marked differences among those with or without a confirmed SARS-CoV-2 infection.

Keywords: Comorbidities, COVID-19, Primary Care

Comorbilidades de los pacientes con COVID-19 atendidos en Atención Primaria durante la primera oleada de la pandemia de SARSCoV-2 en la Comunidad de Madrid

\section{RESUMEN}

Objetivos. Existen publicaciones sobre las comorbilidades y el perfil demográfico en pacientes hospitalizados por COVID-19, pero son escasas aquellas sobre grandes poblaciones atendidas en Atención Primaria (AP). El objetivo de este trabajo es Ilenar este vacio describiendo la prevalencia de ocho comorbilidades (hipertensión arterial, diabetes mellitus, cáncer, enfermedad cardiovascular, asma, enfermedad renal crónica, enfermedad pulmonar obstructiva crónica e insuficiencia cardíaca crónica) en los pacientes de AP durante el inicio de la pandemia por SARS-CoV-2 en la Comunidad de Madrid (CoM), España.

Pacientes y métodos. Estudio observacional retrospectivo que recopila datos registrados en la CoM, entre el 25 de febrero y el 31 de mayo de 2020. Se diferencian dos cohortes de pacientes que acudieron a AP: Grupo-1 ( $N=339.890)$, que incluye todos los pacientes con sospecha de SARS-CoV-2 o infección confirmada; Grupo-2, que es el subgrupo ( $N=48.556$, 14,3\% del Grupo-1) de casos confirmados de COVID-19 mediante prueba RT-PCR.

Resultados. Comparando el Grupo-1 con el Grupo-2 (339.890/48.556 pacientes, respectivamente), los principales resultados fueron los siguientes: edad media (60,9/69,9 años), presencia de al menos una comorbilidad $(33,51 \% / 47,69 \%)$, 
hipertensión arterial (19,74\%/32,74\%), diabetes mellitus $(7,13 \% / 13,75 \%)$, cáncer $(6,56 \% / 10,6 \%)$, enfermedad cardiovascular (4,52\%/9,26\%), asma (7,98\%/6,56\%), enfermedad renal crónica (1,84\%/4,41\%), EPOC (2\%/4,03\%) e insuficiencia cardiaca crónica $(1,14 \% / 2,77 \%)$. La asociación más frecuente fue hipertensión arterial y diabetes (6,56\%/8,38\%).

Conclusiones. Los pacientes atendidos en AP durante la primera ola de la actual pandemia de COVID-19 en la CoM presentaron una tasa muy alta de una o más comorbilidades comunes, con diferencias significativas según tuvieran una infección confirmada o no por SARS-CoV-2.

Palabras clave: Comorbilidades, CoVID-19, Atención Primaria.

\section{INTRODUCTION}

During the first wave of SARS-CoV-2 pandemic, the Community of Madrid (CoM) was one of the most important epicentres of this disease, not only in Spain but also in the world. On March 31st, 2020, at the peak of the first pandemic wave, deaths per 100,000 inhabitants in the CoM were 57.7, tripling that of Spain (17.3), followed by Belgium (14.8), Italy (13.4), France (6.24), and UK (5.6). Accumulated deaths at the time in the CoM $(3,865)$ represented $42.7 \%$ of those registered in Spain $(9,053)$. Also, the CoM recorded a cumulative incidence of 363.22 cases per 100,000 inhabitants in the last 14 days, while Spain recorded 192.3, followed by Italy (122.2), Belgium (103), France (56.6) and UK (40) during the same period $[1,2]$.

The comorbidities associated with patients with COVID-19 are well known, but have generally been obtained from patients with the most severe forms of the disease often requiring hospital admission [3-6].

This is a retrospective observational study based on the database of the CoM. It provides an opportunity to determine the comorbidity burden in the patients seen in Primary Care (PC) for COVID-19 during the first wave of the pandemic in this region.

\section{PATIENTS AND METHODS}

Ethics. The Clinical Research Ethics Committee of Hospital Clínico San Carlos, Madrid (Spain), approved the study (Comité Ético de Investigación Clínica; code: 21/197-E).

The CoM Public Health Service (Servicio Madrileño de Salud, SERMAS) has 430 PC centres and clinics in addition to its hospitals and other services that serve a population of 6.7 million inhabitants $[7,8]$. Since 2012 , the medical records of all patients seen in the PC have been electronically captured in a centralized system of Electronic Health Record (HER) known as "AP-Madrid" (Sistema de Información de Historia Clínica Electrónica Única Centralizada de Atención Primaria).

Design. This is a retrospective observational study based on the information collected in "AP-Madrid" by the family doctors of the SERMAS between February 25th and May 31st, 2020. This study includes information on 339,890 patients with any of the following diagnoses (Figure 1): "infected" with SARS-CoV-2 (code A77.01 of International Classification of Primary Care Second edition, ICPC-2); or "suspected infection" (code A77 of ICPC-2). Two groups were analysed in the study; Group-1: all individuals $(339,890)$ coded as $A 77.01$ or A77; and Group-2: 48,556 individuals from Group- 1 with a positive RT-PCR test (representing 14.3\% of Group-1). During the first wave, some patients were assigned to codes A77.01 or A77 without an RT-PCR test due to a shortage of tests. Only 68,981 patients, representing 20\% of the total in Group-1, underwent the test showing positive results 48,556 (= Group-2). When the two codes coexisted in the same patient, the following hierarchy prevailed: infected case $>$ suspected case.

Setting. The data analysed in this paper were anonymous and obtained from the information provided by the PC management team of SERMAS periodically to the COVID-19 Control Centre (Centro de Control COVID-19, CCC). The authors of this paper had worked at the CCC during the first wave of the pandemic. It was created at the beginning of the COVID-19 pandemic emergency by the CoM Government [9]. The PC forwarded updated information to the CCC, causing some patients to have more than one diagnosis code related to COVID-19, as noted above.

The data captured in CCC were cleaned and analysed with the business intelligence software (specifically, Microsoft Power BI) and presented through interactive dashboards. The decision-making responsibility was not a part of the CCC's tasks.

Variables. The variables analysed included the age ranges, sex, and eight comorbidities: high blood pressure (HBP), diabetes mellitus (DM), cancer (diagnosed in the last 5 years), cardiovascular disease (CVD), asthma, chronic kidney disease (CKD), chronic obstructive pulmonary disease (COPD), and chronic heart failure (CHF).

Statistical analysis. Data are expressed as the mean (standard deviation) for continuous variables, and the absolute and relative frequencies for the categorical variables, as appropriate. Inferential analyses were performed using the McNemar test $(\mathrm{Mn})$ for qualitative variables and the related measures t-test (T) for quantitative variables. All $p$ values lower than 0.05 were deemed statistically significant. For comparisons showing statistical significance, the effect size was reported according to the nature of each variable. The Odds Ratio was reported for the qualitative variables and Cohen's D for the quantitative variables, together with their 95\% confidence intervals. Statistical analyses were performed using the Statistical Package for the Social Sciences (IBM SPSS Statistics for Windows, Version 25.0. Armonk, NY: IBM Corp).

\section{RESULTS}

This observational study analysed a total of 339,890 patients (Group-1) who visited their family doctor for symptoms potentially related to the COVID-19. Figure 1 describes the breakdown of the patients assigned to each diagnostic category, detailing the subsample of patients that underwent an RT- 


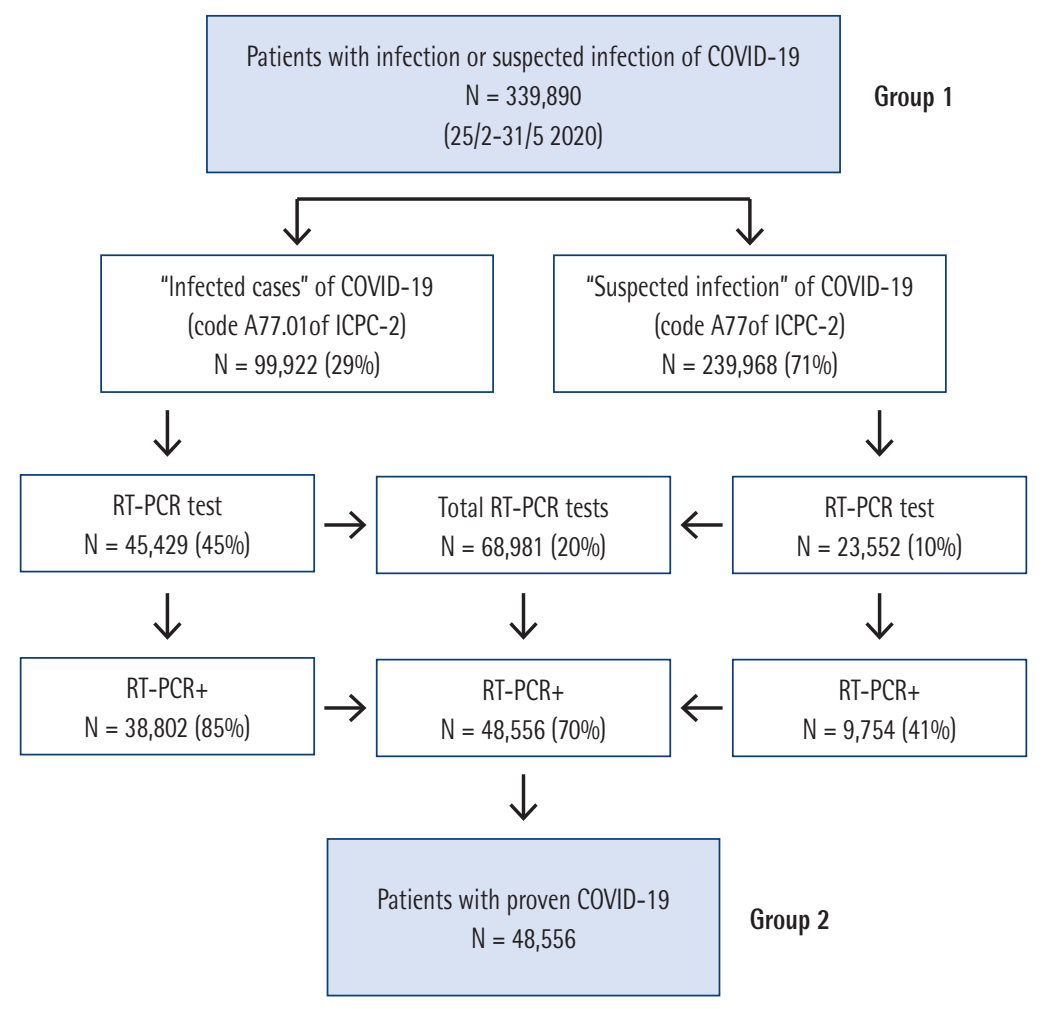

\section{Figure 1 Patients with a code related to COVID-19 in the electronic medical record of Primary Care (AP-Madrid)}

All percentages (\%) refer to the sample (N) that appears in the table immediately above. The two boxes with a grey background represent the two Groups in which this study analyses comorbidities, sex, and age. ICPC-2 = International Classification of Primary Care Second edition. RT-PCR= Reverse transcription polymerase chain reaction. RT-PCR+ = Positive test result.

PCR test, and those that had a positive result (Group-2, 48,556 individuals).

At least one of the eight comorbidities studied was observed in 33.51\% of patients in Group-1 and $47.69 \%$ in Group-2 with a statistically significant difference $(M n=420.2$; $p<0.001$ ). The patients with comorbidities in Group-2 (mean \pm $\mathrm{SD}$ age $=69.95 \pm 15.72$ years) were older than those in Group -1 (mean \pm SD age $=60.90 \pm 18.61$ years) with a significant difference ( $T=240 ; p<0.001 ; D^{\prime}=0.52 ; D^{\prime} 95 \%$ [0.50 to 0.54$]$ ).

The mean \pm SD age in Group -2 was $59.07 \pm 19.04$ years, whereas in Group-1 47.97 \pm 19.5 years ( $T=119.8 ; p<0.001$; $D^{\prime}=0.57$; D' $95 \%$ [0.56 to 0.58]). There was a higher proportion of women in Group-1 (57.29\%) than in Group-2 (53.19\%) $(\mathrm{Mn}=290.9 ; p<0.001 ;$ OR $1.077 ;$ OR 95\% [1.68 to 1.987$])$. In Groups 1 and 2, the mean \pm SD age for men was $47.4 \pm 19.75$ and $60.2 \pm 17.89$ years, respectively; while the mean \pm SD age for women was $48.39 \pm 19.29$ and $58.06 \pm 19.94$ years, respectively. Figure 2 shows the sex and age distribution of subjects included in the Groups 1 and 2.

Specifically, in Group-2 (proven COVID-19) the frequen- cies of the eight comorbidities (Table 1) were HBP (32.74\%), DM (13.75\%), cancer (10.60\%), CVD (9.26\%), asthma (6.56\%), CKD (4.41\%), COPD (4.03\%), and CHF (2.77\%). Generally, in Group-2, the relative frequencies of comorbidities were higher, particularly among men (where HBP, DM and cancer stand out).

Table 2 shows the absolute and relative frequencies of comorbidities, alone or in combination, if their occurrence is greater than $0.5 \%$. In both groups, the highest frequency combination was HBP and DM. Finally, Table 3 lists the eight comorbidities (in absolute values) analysed for both groups in this study, stratified by sex (in relative values) and age ranges.

\section{DISCUSSION}

Our work demonstrates that a high frequency of patients with comorbidities in the population during the first wave of the COVID-19 pandemic sought care in the PC network of the CoM. Individuals with confirmed COVID-19 had a higher proportion of underlying diseases causing their high morbidity and mortality in the period investigated. 

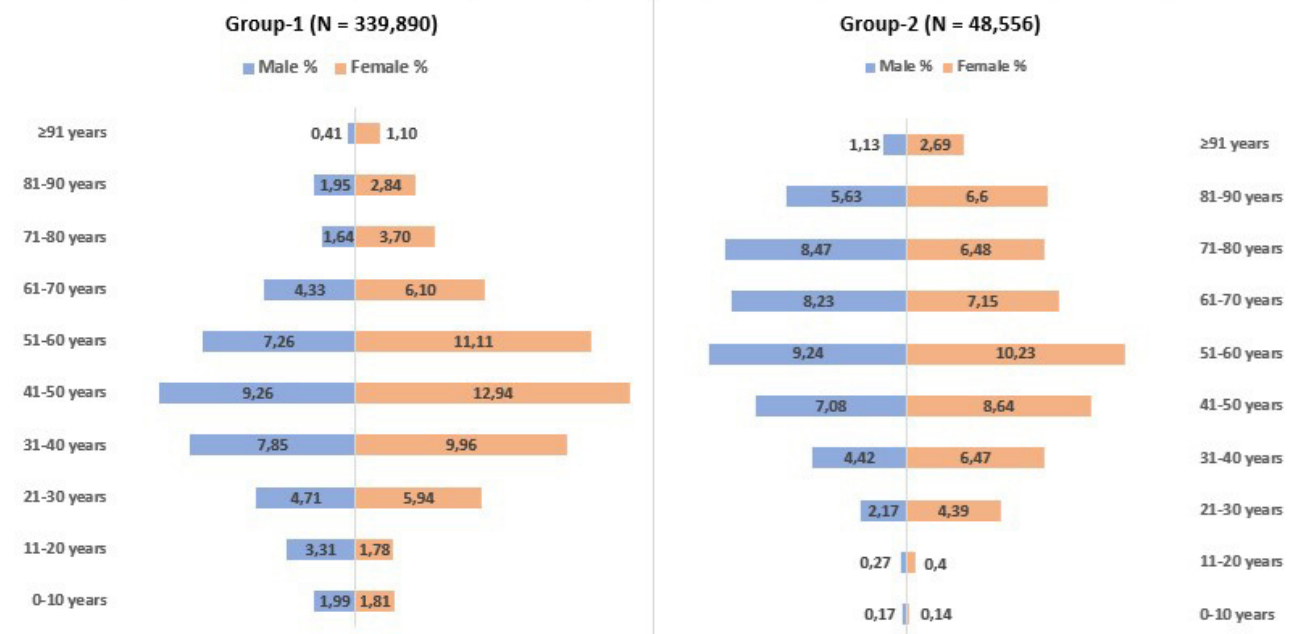

\begin{tabular}{l|l} 
Figure 2 & Relative frequency of the age range in Groups 1 and 2 stratified by sex.
\end{tabular}

\begin{tabular}{|c|c|c|c|c|c|c|c|c|c|}
\hline \multirow[t]{3}{*}{ Table 1} & \multicolumn{9}{|c|}{ Prevalence of comorbidities globally and stratified by sex in Groups 1 and 2 . } \\
\hline & \multicolumn{3}{|c|}{ Group-1; N (\%) } & \multicolumn{3}{|c|}{ Group-2; N (\%) } & \multicolumn{3}{|c|}{ General population (CoM) \% [23] } \\
\hline & Total & Male & Female & Total & Male & Female & Total & Male & Female \\
\hline Cohort & 339,890 & $145,183(42.71)$ & $194,707(57.28)$ & 48,556 & $22,731(46.81)$ & $25,825(53,18)$ & & & \\
\hline HBP & $67,084(19.74)$ & $30,751(21.18)$ & $36,333(18.66)$ & $15,899(32.74)$ & $8,080(35.55)$ & $7,819(30.28)$ & 19.08 & 19.87 & 18.57 \\
\hline Asthma & 27,107 (7.98) & $9,645(6.64)$ & $17,462(8.97)$ & $3,183(6.56)$ & $1,053(4.63)$ & $2,130(8.25)$ & 4.88 & 3.19 & 6.4 \\
\hline DM & $24,227(7.13)$ & $13,068(9.00)$ & 11,159 (5.73) & $6,677(13.75)$ & $3,932(17.30)$ & $2,745(10.63)$ & 7.39 & 7.56 & 7.16 \\
\hline Cancer & $22,313(6.56)$ & $9,319(6.42)$ & $12,994(6.67)$ & $5,147(10.60)$ & $2,792(12.28)$ & 2,355 (9.12) & 1.69 & 1.02 & 2.3 \\
\hline CVD & $15,363(4.52)$ & $8,824(6.08)$ & 6,539 (3.36) & 4,495 (9.26) & $2,832(12.46)$ & $1,663(6.44)$ & 1.21 & 1.18 & 1.23 \\
\hline COPD & $6,795(2.00)$ & $4,706(3.24)$ & $2,089(1.07)$ & $1,958(4.03)$ & $1,559(6.86)$ & $399(1.55)$ & 2.23 & 1.51 & 2.88 \\
\hline CKD & $6,247(1.84)$ & $3,273(2.25)$ & $2,974(1.53)$ & $2,141(4.41)$ & 1,208 (5.31) & $933(3.61)$ & п.а. & п.а. & п.а. \\
\hline CHF & 3,859 (1.14) & $1,604(1.10)$ & 2,255 (1.16) & $1,345(2.77)$ & 632 (2.78) & 713 (2.76) & п.а. & п.а. & п.а. \\
\hline
\end{tabular}

HBP: High Blood Pressure; DM: Diabetes Mellitus; CVD: Cardiovascular Disease; COPD: Chronic Obstructive Pulmonary Disease; CKD: Chronic Kidney Disease; CHF: Chronic Heart Failure; CoM: Comunidad de Madrid.

Note. The percentage associated with the total number of individuals with each comorbidity has been calculated with respect to the size of the sample to which it belongs (Group-1 $\mathrm{N}=339.890$ and Group-2 $\mathrm{N}=48.556$ ). The percentage of comorbidities in both sexes has been calculated with respect to the sex distribution in each of the groups.

The information provided in this article is concordant with an in-house report of the PC department of SERMAS [10], and few studies published in Spain [11-15] and Europe [16-18]. Generally, the comorbidities accompanying patients with COVID-19 have been studied more in the hospital setting than in PC [19-22]. For this reason, along with the fact that our analysis had a much larger sample size than the other published studies (the entire CoM), it is difficult to establish comparisons. Furthermore, the comparison becomes increasingly difficult due to the fact that there are no official statistics on comorbidities in the general population according to the age and sex.
In our paper, we have tried to address this problem by offering in Table 1 the data from the National Health Survey [23].

Unlike our study, the SERMAS report does not include the comorbidities of patients with positive RT-PCR tests that is equivalent to our Group-2. However, it compares the comorbidities of patients seen in the PC who were hospitalized versus those who did not need it. We observed that the frequencies of comorbidities in our Group-1 were analogous to the group that was not hospitalized, while the frequencies of Group-2 were comparable to those that required hospitalization. These results are consistent with previous studies involving PC pa- 


\begin{tabular}{|c|c|c|c|}
\hline Table 2 & $\begin{array}{l}\text { Absolute and relati } \\
\text { frequent comorbidi } \\
\text { Groups } 1 \text { and } 2 \text {. }\end{array}$ & $\begin{array}{l}\text { e (>0.5\%) frequenci } \\
\text { ies and its combinat }\end{array}$ & $\begin{array}{l}\text { of most } \\
\text { ns in }\end{array}$ \\
\hline Group-1 & $N(\%)$ & Group-2 & N (\%) \\
\hline Comorbidities & $113,884(33.51 \%)$ & Comorbidities & $23,156(47.69 \%)$ \\
\hline HBP & $32,969(28.95)$ & HBP & $6,231(26.91)$ \\
\hline Asthma & $19,511(17.13)$ & $\mathrm{DM}+\mathrm{HBP}$ & $1,941(8.38)$ \\
\hline Cancer & 9,557 (8.39) & Asthma & $1,668(7.2)$ \\
\hline $\mathrm{DM}+\mathrm{HBP}$ & $7,469(6.56)$ & Cancer & $1,566(6.76)$ \\
\hline DM & $5,935(5.21)$ & DM & $1,214(5.24)$ \\
\hline $\mathrm{HBP}+$ Cancer & 4,422 (3.88) & $\mathrm{HBP}+$ Cancer & $1,074(4.64)$ \\
\hline$C V D+H B P$ & $3,443(3.02)$ & $C V D+H B P$ & $920(3.97)$ \\
\hline Asthma + HBP & $3,057(2.68)$ & CVD & $647(2.79)$ \\
\hline CVD & $2,947(2.59)$ & Asthma + HBP & $552(2.38)$ \\
\hline $\mathrm{DM}+\mathrm{CVD}+\mathrm{HBP}$ & $1,722(1.51)$ & $\mathrm{DM}+\mathrm{CVD}+\mathrm{HBP}$ & $546(2.36)$ \\
\hline COPD & $1,684(1.48)$ & $C K D+H B P$ & $459(1.98)$ \\
\hline$E R C+H B P$ & $1,382(1.21)$ & $\mathrm{DM}+\mathrm{HBP}+$ Cancer & $434(1.87)$ \\
\hline $\mathrm{DM}+\mathrm{HBP}+$ Cancer & 1,289 (1.13) & $\mathrm{COPD}+\mathrm{HBP}$ & $345(1.49)$ \\
\hline COPD + HBP & $1,159(1.02)$ & COPD & $310(1.34)$ \\
\hline Asthma + Cancer & $850(0.75)$ & $\mathrm{DM}+\mathrm{CKD}+\mathrm{HBP}$ & $243(1.05)$ \\
\hline $\mathrm{CVD}+\mathrm{HBP}+$ Cancer & $779(0.68)$ & $\mathrm{DM}+\mathrm{CVD}$ & $242(1.05)$ \\
\hline $\mathrm{DM}+\mathrm{CVD}$ & $772(0.68)$ & $\mathrm{CVD}+\mathrm{HBP}+$ Cancer & $227(0.98)$ \\
\hline Asthma + DM + HBP & $670(0.59)$ & $\mathrm{HBP}+\mathrm{CHF}$ & $210(0.91)$ \\
\hline $\mathrm{DM}+\mathrm{CKD}+\mathrm{HBP}$ & $646(0.57)$ & $\mathrm{DM}+$ Cancer & $168(0.73)$ \\
\hline CKD & $643(0.56)$ & $C V D+C K D+H B P$ & $160(0.69)$ \\
\hline $\mathrm{DM}+$ Cancer & $592(0.52)$ & Asthma + DM + HBP & $159(0.69)$ \\
\hline \multirow[t]{6}{*}{$\mathrm{HBP}+\mathrm{CHF}$} & $589(0.52)$ & $\mathrm{DM}+\mathrm{CVD}+\mathrm{HBP}+$ Cancer & $152(0.66)$ \\
\hline & & CKD & $148(0.64)$ \\
\hline & & $\mathrm{DM}+\mathrm{COPD}+\mathrm{HBP}$ & $139(0.6)$ \\
\hline & & $\mathrm{DM}+\mathrm{CVD}+\mathrm{CKD}+\mathrm{HBP}$ & $138(0.6)$ \\
\hline & & CVD + Cancer & $132(0.57)$ \\
\hline & & $\mathrm{DM}+\mathrm{HBP}+\mathrm{CHF}$ & $117(0.51)$ \\
\hline
\end{tabular}

HBP: High Blood Pressure; DM: Diabetes Mellitus; CVD: Cardiovascular Disease; COPD: Chronic Obstructive Pulmonary Disease; CKD: Chronic Kidney Disease; CHF: Chronic Heart Failure.

tients that tested positive for SARS-CoV-2 [19] or hospitalized patients [14].

The age ranges for Groups 1 and 2 were contrasted with the general population of the CoM [24]. This showed that the proportion of patients between 31 and 60 years in Group-1 (58.5\%) was higher than that described for the general population (45.6\%), but not so in the Group-2 (46.1\%). However, the percentage of the general population (13.13\%) over 70 years of age was close to that of the Group-1 (11.6\%) but far from that seen in Group-2 (28.8\%).

In most of the published studies, and in our analysis, the female sex predominates among COVID-19 patients. In Group-1, the relative frequency of women (57.3\%) was the same as that observed for all the patients analysed in the SERMAS report [10] $(57.2 \%)$, and in the other publications $[18,19]$. The category of non-hospitalized cases in the National Epidemiological Surveillance Network (RENAVE) cohort also consists of a higher proportion of women (65.5\%) [15]. Similarly, the female sex (53.2\%) is also prevalent in our Group-2. This preponderance of the female sex contrasts with the findings of the studies carried out in the hospitalized patients where, the male sex was most frequent $[5,14,16,17]$. In the SERMAS report [10] and the RENAVE cohort 


\section{\begin{tabular}{l|l} 
Table 3 & Comorbidities: age range and sex distribution in Groups 1 and 2
\end{tabular}}

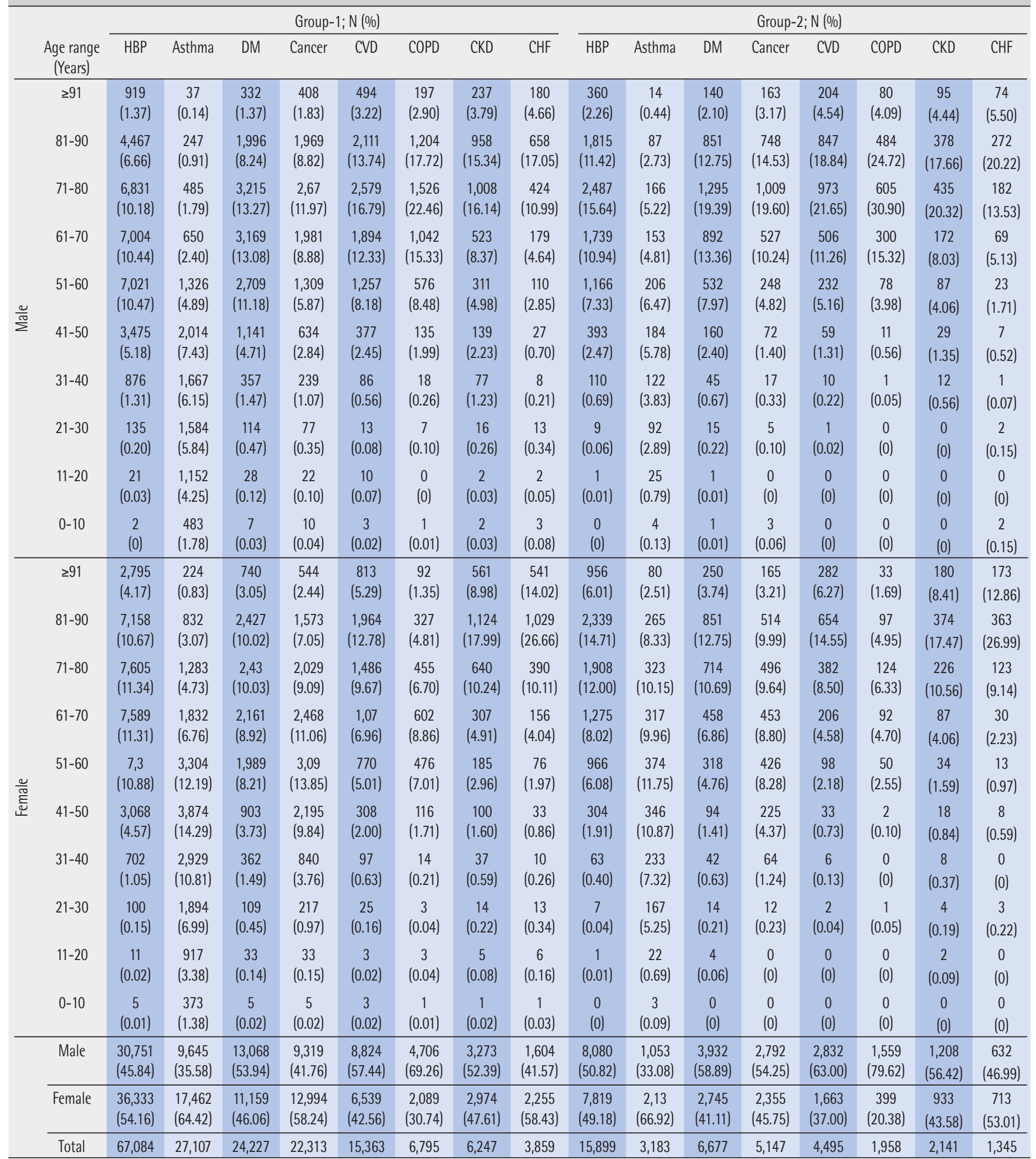

HBP: High Blood Pressure; DM: Diabetes Mellitus; CVD: Cardiovascular Disease; COPD: Chronic Obstructive Pulmonary Disease; CKD: Chronic Kidney Disease; CHF: Chronic Heart Failure.

Note. The percentage (included in parentheses) has been calculated with respect to the total number of patients with a certain comorbidity in each sex and age group. 
[15], men predominated (54.3\% and 55.6\%, respectively) among the patients who had to be hospitalized.

From the beginning of the pandemic, publications focused on identifying the variables that could predict the outcomes in patients with COVID-19. The Chinese Centre for Disease Control and Prevention reported in an early study of 44,672 people $(1,023$ deaths) that CVD, HBP, DM, respiratory disease, and cancer were associated with an increased risk of death [25]. It also concluded that the fatality rate was increasing with age, and the male patients had a higher risk of death than the female patients. The HBP (most frequent comorbidity in our study) was observed to be an important source of complications such as heart failure, and adverse results [26], thus proving the effect that previous comorbidities have on the evolution of patients with COVID-19. This emphasizes the need to maintain routine control of the chronically ill, especially in pandemic situations like the one we live in [27]. Data collected throughout Spain until May 21st, 2020, by RENAVE [28] also demonstrate that the age and gender are significant risk factors for severe COVID-19 outcomes. For instance, 68\% of COVID-19-related ICU admissions were men, and more than 55\% of hospitalizations and deaths were also from this sex. This observation, together with the data from our study, leads us to hypothesize the reason for the unfavourable profile of our Group 2 (proven COVID-19). The fact that $47.7 \%$ of the individuals in this group presented at least one comorbidity with an average age of 69.9 years, helps us to understand the distressing outcomes seen in the CoM during the first wave of the current pandemic.

Similar to our study, the SERMAS report [10] underpins the crucial role of the PC in the period studied. Out of its total cohort, only $10.6 \%$ were hospitalized, and of the 222,905 patients with symptoms -cough (70\%), fever (44\%) and dyspnoea (31\%) were the most frequent. About $90.7 \%$ of this group had their first consultation in a PC centre, while the rest $(9.3 \%)$ had it in the hospital.

The limitations of this paper are due to the circumstances surrounding the outbreak of the first wave. The scarcity of the microbiological tests could explain, in part, why most cases in our cohort (71\%) were labelled as "suspected infection". However, it should be mentioned that when a RT-PCR test could be performed, it was positive in $85 \%$ of patients diagnosed as infected, whereas, in those diagnosed as suspected, the percentage of positives dropped to $41 \%$ (Figure 1). This finding gives value to the clinical judgment of PC doctors, especially, considering that they were evaluating a new nosological entity. It should also be noted that the CCC received the information from the SERMAS. Among the data not received and the ones that are most lacking are those related to the symptomatology profile, hospitalization, and the mortality of patients seen by the family doctors. Despite these limitations, the strength of this study lies in the large sample of COVID-19 patients it evaluates using a robust study design that stratifies individuals according to the comorbidities, sex, age, and the result of RT-PCR tests (Tables 1-3).

In summary, the impact of the first wave of the SARS-CoV-2 pandemic on the health care system in the CoM is explained in addition to other relevant factors. It was observed that the older individuals with a significant disease burden became sicker and developed severe disease. As the figures show, many patients seeking medical attention for COVID-19 were seen at the PC centres emphasising their key role. This is especially true when a health crisis erupts overwhelming the healthcare systems and the hospitals with unusually high demand for patient care [29]. Therefore, it is essential that PC physicians can identify, diagnose, and carry out a follow-up on patients whose comorbidities, sex and age make them vulnerable and prone to hospitalization. Additionally, the data provided in this paper should serve as a useful guide to prescribe current therapies such as the monoclonal antibodies or any other available in the future.

\section{FUNDING}

This project has received assistance from "Actuaciones Coronavirus" (Community of Madrid, Spain), project number: 2020/000164.

\section{CONFLICT OF INTEREST}

All authors declare no conflict of interest.

\section{REFERENCES}

1. Centro de Coordinación de Alertas y Emergencias Sanitarias CCAE. Actualización n 62. Enfermedad por el coronavirus (COVID-19). 01/04/2020. 2020. Available from: https://www.mscbs.gob.es/profesionales/saludPublica/ccayes/alertas[Actual/nCov/situacionActual.htm [cited 9.05.21].

2. ECDC. Historical data (to 14 December 2020) on the daily number of new reported COVID-19 cases and deaths worldwide. 2020. Available from: https://www.ecdc.europa.eu/en/publications-data/ download-todays-data-geographic-distribution-COVID-19-cases-worldwide [cited 9.05.21].

3. Poblador-Plou B, Carmona-Pírez J, loakeim-Skoufa I, Poncel-Falcó A, Bliek-Bueno K et al. Baseline Chronic Comorbidity and Mortality in Laboratory-Confirmed COVID-19 Cases: Results from the PRECOVID Study in Spain. Int J Environ Res Public Health. 2020;17(14). doi: 10.3390/ijerph17145171.

4. Wang $X_{1}$ Fang $X_{1}$ Cai Z, Wu $X_{1}$ Gao $X_{1}$ Min J, et al. Comorbid Chronic Diseases and Acute Organ Injuries Are Strongly Correlated with Disease Severity and Mortality among COVID-19 Patients: A Systemic Review and Meta-Analysis. Research (Wash D C). 2020 Apr 19;2020:2402961. doi: 10.34133/2020/2402961. eCollection 2020.

5. Cheng $S$, Zhao $Y$, Wang $F$, Chen $Y$, Kaminga $A C, X u$ H. Comorbidities' potential impacts on severe and non-severe patients with COVID-19: A systematic review and meta-analysis. Medicine (Baltimore). 2021;100(12):e24971. doi: 10.1097/ md.0000000000024971.

6. Kim DH, Park HC, Cho A, Kim J, Yun KS, Kim J, et al. Age-adjusted Charlson comorbidity index score is the best predictor for severe clinical outcome in the hospitalized patients with COVID-19 in- 
fection. Medicine (Baltimore). 2021;100(18):e25900. doi: 10.1097/ md.0000000000025900.

7. Salud Madrid. Memoria anual de actividad del Servicio Madrileño de Salud año 2019. Servicio Madrileño de Salud; 2020. Available from: https://www.comunidad.madrid/servicios/salud/memorias-e-informes-servicio-madrileno-salud [cited 9.05.21]

8. Instituto Nacional de Estadística. Principales series de población desde 1998. Comunidades Autónomas. Comunidad de Madrid 2020. Available from: https://www.ine.es/jaxi/Tabla.htm?path=/ t20/e245/p08/I0/\&file=02002.px [cited 9.05.21]

9. Comunidad de Madrid. Díaz Ayuso visita el nuevo Centro de Control permanente del coronavirus de la Comunidad de Madrid. Acción de Gobierno Actualidad 14.3.2020. Available from: https:// www.comunidad.madrid/notas-prensa/2020/03/14/diaz-ayuso-visita-nuevo-centro-control-permanente-coronavirus-comunidad-madrid [cited 12.05.21]

10. Gerencia Asistencial Atención Primaria de Madrid. Informe Técnico COVID-19 Atención Primaria, marzo-abril 2020. Servicio Madrileño de Salud; 2020. Available from: https://isanidad.com/wp-content/ uploads/2020/06/Informe-COVID-19-AP-Madrid.pdf [cited 9.04.21]

11. de Nicolás Jiménez JM, Blázquez Recio LM, Fabregat Domínguez MT, Palomo Cobos L. COVID-19 and assistance effort in Primary Care. Aten Primaria, 2020 0ct;52(8):588-590. doi: 10.1016/j. aprim.2020.06.002

12. Muñoz MA, López-Grau M. Lessons learned from the approach to the COVID-19 pandemic in urban primary health care centres in Barcelona, Spain. Eur J Gen Pract, 2020 Dec;26(1):106-107. doi: 10.1080/13814788.2020.1796962

13. Montenegro P, Brotons $C$, Serrano J, Fernández D, García-Ramos $C$, Ichazo $B$, et al. Community seroprevalence of COVID-19 in probable and possible cases at primary health care centres in Spain. Fam Pract, 2021 Mar 29;38(2):154-159. doi: 10.1093/fampra/cmaa096

14. Rogero-Blanco $E_{1}$ Gonzalez-Garcia $V_{1}$ Medina-Garcia $R$, Muñoz-Molina P, Machin-Hamalainen S, López-Rodríguez J, et al. Characteristics of a COVID19 confirmed case series in Primary Care (COVID19-PC Project): a cross-sectional study. Fam Pract, 2021 Apr 8;22(1):66. doi: 10.1186/s12875-021-01419-7

15. Working group for the surveillance and control of COVID-19 in Spain; Members of the Working group for the surveillance and control of COVID-19 in Spain. The first wave of the COVID-19 pandemic in Spain: characterisation of cases and risk factors for severe outcomes, as of 27 April 2020. Euro Surveill. 2020 Dec;25(50):2001431. doi: 10.2807/1560-7917. ES.2020.25.50.2001431.

16. Hull SA, Williams $C_{1}$ Ashworth $M$, Carvalho $C$, Boomla K. Prevalence of suspected COVID-19 infection in patients from ethnic minority populations: a cross-sectional study in primary care. Br J Gen Pract, 2020 Oct 1;70(699):e696-e704. doi: 10.3399/bjgp20X712601

17. Nystad W, Hjellvik V, Larsen IK, Ariansen I, Helland E, Johansen KI, et al. Underlying conditions in adults with COVID-19. Tidsskr Nor Laegeforen, 2020 Sep 16;140(13). doi: 10.4045/tidsskr.20.0512

18. de Lusignan S, Dorward J, Correa A, Jones N, Akinyemi O, Amirthalingam $G$, et al. Risk factors for SARS-CoV-2 among pa- tients in the Oxford Royal College of General Practitioners Research and Surveillance Centre primary care network: a cross-sectional study. Lancet Infect Dis, 2020 Sep;20(9):1034-1042. doi: 10.1016/S1473-3099(20)30371-6

19. Jutzeler $C R$, Bourguignon $L$, Weis $C V$, Tong $B$, Wong $C$, Rieck $B$, et al. Comorbidities, clinical signs and symptoms, laboratory findings, imaging features, treatment strategies, and outcomes in adult and pediatric patients with COVID-19: A systematic review and meta-analysis. Travel Med Infect Dis, Sep-Oct 2020;37:101825. doi: 10.1016/j.tmaid.2020.101825

20. Borobia AM, Carcas AJ, Arnalich F, Álvarez-Sala R, Monserrat-Villatoro J, Quintana M, et al. A Cohort of Patients with COVID-19 in a Major Teaching Hospital in Europe. J Clin Med, 2020 Jun 4;9(6):1733. doi: 10.3390/jcm9061733

21. Jiménez $E$, Fontán-Vela $M$, Valencia J, Fernandez-Jimenez I, Álvaro-Alonso EA, Izquierdo-García $E_{1}$ et al. Characteristics, complications and outcomes among 1549 patients hospitalised with COVID-19 in a secondary hospital in Madrid, Spain: a retrospective case series study. BMJ Open, 2020 Nov 10;10(11):e042398. doi: 10.1136/bmjopen-2020-042398

22. Casas-Rojo JM, Antón-Santos JM, Millán-Núñez-Cortes J, Lumbreras-Bermejo C, Ramos-Rincón JM, Roy-Vallejo E, et al. Clinical characteristics of patients hospitalized with COVID-19 in Spain: Results from the SEMI-COVID-19 Registry. Rev Clin Esp, 2020 Nov;220(8):480-494. doi: 10.1016/j.rce.2020.07.003

23. Encuesta Nacional de Salud de España, 2017. Estado de Salud. https://www.mscbs.gob.es/estadEstudios/estadisticas/encuestaNacional/encuestaNac2017/ENSE17_MOD1_REL.pdf.

24. Instituto Nacional de Estadística. Principales series de población desde 1998. Comunidades Autónomas. Comunidad de Madrid 2020. Available from: https://www.ine.es/jaxi/Tabla.htm?path=/ t20/e245/p08/I0/\&file=02002.px [cited 15.04.21]

25. Deng $G$, Yin $M$, Chen $X$, Zeng F. Clinical determinants for fatality of 44,672 patients with COVID-19. Crit Care. 2020 Apr 28;24(1):179. doi: 10.1186/s13054-020-02902-w.

26. Sheppard JP, Nicholson BD, Lee J, McGagh D, Sherlock J, Koshiaris $\mathrm{C}$ et al. Association Between Blood Pressure Control and Coronavirus Disease 2019 Outcomes in 45,418 Symptomatic Patients With Hypertension: An Observational Cohort Study. Hypertension. 2021 Mar 3;77(3):846-855. doi: 10.1161/HYPERTENSIONAHA.120.16472.

27. Wright A, Salazar A, Mirica M, Volk LA, Schiff GD. The Invisible Epidemic: Neglected Chronic Disease Management During COVID-19. J Gen Intern Med. 2020 Sep;35(9):2816-2817. doi: 10.1007| s11606-020-06025-4.

28. Informe sobre la situación de COVID-19 en España. Informe $n^{\circ} 32.21$ de mayo de 2020. p. 6 Available from: https://www.isciii.es/QueHacemos/Servicios/VigilanciaSaludPublicaRENAVE/EnfermedadesTransmisibles/Paginas/-COVID-19.-Informes-previos.aspx [cited 20.05.21]

29. Sánchez-Úbeda EF, Sánchez-Martín $P$, Torrego-Ellacuría $M$, Rey-Mejias ÁD, Morales-Contreras MF, Puerta JL. Flexibility and Bed Margins of the Community of Madrid's Hospitals during the First Wave of the SARS-CoV-2 Pandemic. Int. J. Environ. Res. Public Health 2021, 18, 3510. doi.org/10.3390/ijerph1807 3510. 
María Ema Molas ${ }^{1,2}$

Hernando Knobel ${ }^{2,3}$

Olivia Ferrández ${ }^{4}$

Marta de Antonio Cuscó ${ }^{4}$

Nuria Carballo Martínez ${ }^{4}$

Cristina Rodríguez $\mathrm{Caba}^{5}$

Sonia Luque ${ }^{4}$

Ana Guelar ${ }^{3}$

Silvia Castañeda Espinosa ${ }^{3}$

Santiago $\mathrm{Grau}^{4}$

\section{Impact of the COVID-19 pandemic: Community and hospital shared pharmaceutical care model. Satisfaction and acceptability of patients with HIV infection on antiretroviral treatment}

\author{
${ }^{1}$ Infectious Diseases Department, Hospital de la Santa Creu i Sant Pau, Barcelona, Spain. \\ ${ }^{2}$ Department of Medicine, Universitat Autònoma de Barcelona, Barcelona, Spain \\ ${ }^{3}$ Infectious Diseases Department, Hospital del Mar, Barcelona, Spain. \\ ${ }^{4}$ Pharmacy Department, Hospital del Mar, Barcelona, Spain. \\ ${ }^{5}$ Official College of Pharmacists of Barcelona, Barcelona, Spain
}

Article history

Received: 26 March 2021; Revision Requested: 4 June 2021; Revision Received: 4 September 2021; Accepted: 9 September 2021; Published: 26 November 2021

\section{ABSTRACT}

Background. The health crisis due to the COVID-19 pandemic is a challenge in the dispensing of outpatient hospital medication (OHM). Models of Antiretroviral Therapy (ART) based on community pharmacy support (ARTCP) have proven to be successful. The aim was to evaluate the degree of satisfaction, acceptability and limitations of the implementation of ARTCP, in the context of a pandemic, in our environment.

Methods. Descriptive cross-sectional study carried out in a Barcelona hospital, during the months of July-November 2020. A telephone survey was carried out via a questionnaire on the quality dimensions of the model (degree of satisfaction, acceptability) and associated inconveniences. Data collected: demographics, antiretroviral treatment (ART), concomitant medication, drug interactions (DDIs), CD4 lymphocyte count and plasma viraemia. Data analysis included descriptive statistics.

Results. A total of 533 (78.0\%) HIV patients receiving ART were included. 71.9\% (383/533) of these patients were very satisfied and $76.2 \%$ preferred attending the community pharmacy rather than the hospital. The mean satisfaction rating was 9.3 (DS: 1.4). The benefits reported were: 1) proximity to home $(406: 76.1 \%)$; 2) lower risk of contagion of COVID-19 (318: 59.7\%); 3) shorter waiting time (201: 37.1\%); 4) time flexibility $(104: 19.5 \%)$; 5) reduction of financial expenses (35: 6.57\%). A total of 11 (2\%) patients reported no benefit. Only 22.9\% reported disadvantages associated with ARTCP: 1) lack of privacy (65: 12.2\%); 2) lack of coordinationorganization (57: 10.7\%).

Conclusion. The COVID-19 pandemic has had an impact

Correspondence:

Santiago Grau Cerrato

Pharmacy Department, Hospital del Mar, Barcelona, Spain

Telephone: +34 600695281

Fax: +34 932483254

E-mail:90126@parcdesalutmar.cat on the provision of pharmaceutical care for HIV patients. The ARTPC model has proved efficient, with patients reporting a high degree of satisfaction.

Keywords: Antiretroviral therapy, pharmaceutical care; COVID-19

Impacto de la pandemia COVID-19: Modelo de atención farmacéutica compartida comunitaria y hospitalaria. Satisfacción y aceptabilidad de pacientes con infección VIH en tratamiento antirretroviral

\section{RESUMEN}

Introducción. La crisis sanitaria por la pandemia COVID-19 plantea un desafío en la dispensación de la medicación hospitalaria de dispensación ambulatoria (MHDA). Los modelos de terapia antirretroviral basados en el apoyo de la farmacia comunitaria (TARFC) han demostrado tener éxito. El objetivo del estudio fue evaluar el grado de satisfacción, aceptabilidad y limitaciones de la implementación del TARFC, en contexto de pandemia, en nuestro entorno.

Métodos. Estudio descriptivo transversal realizado en un hospital de Barcelona, durante los meses de julio-noviembre del 2020. Se realizó una encuesta telefónica, mediante un cuestionario sobre dimensiones de calidad del modelo (grado de satisfacción, aceptabilidad) e inconvenientes asociados. Se recogieron datos: demográficos, tratamiento antirretroviral (TAR), medicación concomitante, interacciones farmacológicas (DDIs), recuento de linfocitos CD4 y viremia plasmática. El análisis de datos incluyó estadistica descriptiva.

Resultados. Se incluyeron 533 pacientes VIH adherentes al TAR. El 71,9\% (383/533) de pacientes estaban muy satisfechos y el 76,2\% preferian acudir a la farmacia comunitaria frente a la hospitalaria. La calificación de satisfacción media fue de 9,3 (DS: 1,4). Los beneficios reportados fueron: 1) cercanía al domicilio $(406: 76,1 \%)$; 2 ) menor riesgo de contagio 
de COVID-19 (318: 59,7\%) 3) menor tiempo de espera (201: $37,1 \%)$; 4) flexibilidad horaria (104: 19,5\%); 5) reducción de gastos económicos (35: 6,57\%). Un total de 11 (2\%) pacientes no reportaron ningún beneficio. Únicamente el 22,9\% reportaron desventajas asociadas al TARFC: 1) falta de privacidad $(65: 12,2 \%) ; 2)$ falta de coordinación-organización $(57: 10,7 \%)$

Conclusión. La pandemia de COVID-19 tiene un impacto en la prestación de atención farmacéutica al VIH. El modelo TARFC ha resultado eficiente con un elevado grado de satisfacción por parte de los pacientes.

Palabras clave: tratamiento antirretroviral, modelo de atención farmacéutica; COVID-19

\section{INTRODUCTION}

The COVID-19 pandemic is putting great pressure on health systems around the world [1], with important consequences for both public health, as well as the function of health structures together with the practicing of their professionals. Due to this situation, alternatives to the hospital administration of antiretroviral medication have had to be sought. In order to guarantee an adequate provision of services, as well as to promote decongestion in hospitals and combat viral spread [2], a series of measures were carried out to ensure patient access to medication. Community pharmacies are essential services authorized to continue their activity during the emergency [3], and community pharmacists are in a key position to provide priority responses to a pandemic, including the management of patients with chronic diseases [4].

Previous studies [5-7] carried out under different settings $[8,9]$ evaluated the feasibility, acceptability and results of a differentiated model of ART dispensing based on the community pharmacy, demonstrating good clinical results (viral suppression, CD4 counts), a higher rate of adherence to ART [10] and the better acceptance of treatment by these patients.

Although the aforementioned studies have been carried out in countries with a healthcare system different from ours, as Canada and the United States, the results point towards a positive benefit derived from the inclusion of community pharmacies in the healthcare process.

In this context, CatSalut issued a resolution with the Official College of Pharmacists of Barcelona and the Hospital del Mar, in which the dispensing of OHM medication was contemplated in the non-face-to-face mode, including dispensing via community pharmacies. The present study aims to evaluate the satisfaction of HIV patients on ART in the setting of an ART dispensing model via community pharmacies, during the pandemic.

\section{MATERIAL AND METHODS}

Design and scope of the study. Patients. OHM Dispensing Circuit Through Community Pharmacies. Telematic visits. Evaluation of the satisfaction of patients adhered to the shared care model. Data collected. Statistical analysis.

\section{RESULTS}

Participants and characteristics of antiretroviral treatment. A total of 533 HIV patients were included in the study from a cohort of 683 HIV patients adhered to ART who, at the time of the study, agreed to participate in the project of shared pharmaceutical care with community pharmacies. 150 (21.9\%) patients were excluded (Figure 1).

The characteristics of the patients included are summarized in Table 1. The majority (73.5\%) were Caucasian and men (82.6\%), the mean age was 48 years (DS: 11.9$) .75 .2 \%$ (401/533) of patients received triple ART regimens, 108 (20.3\%) dual therapy patients and 22 (4.1\%) monotherapy patients.

The antiretroviral treatment used by the 533 patients included can be summarized as 57\% (304/533) received regimens based on integrase inhibitors (INI); $18.9 \%$ received regimens based on non-analog reverse transcriptase (NNRTI); 13.9\% took a protease inhibitor potentiated based therapy; $86.1 \%$ of patients received nucleoside / nucleotide analog reverse transcriptase; and 10.8\% other combination regimens. Triple therapy was used by $75.2 \%$, and mono or dual therapy by $24.4 \%$ of patients.

The co-medicated patients were 57\% (304/533), with a median of 3 drugs per patient and with $16.7 \%$ of patients taking 5 or more drugs. Recreational or abuse drugs were taken by 33\% of patients 33\% and 6\% of them for "chem-sex" purposes. Among the prescribed drugs, the most frequent were: psychotropic drugs (anxiolytics 14.3\%, antidepressants $13.9 \%$, anticonvulsants $8.1 \%$, neuroleptics $4.5 \%$, methadone 4.5\%); anti-hypertensive (ACE inhibitors or angiotensin receptor blockers $12.1 \%$ beta blockers $5.3 \%$, diuretics $4.7 \%$, calcium-channel blockers 4.5\%) lipid-lowering and oral antidiabetics (statins 15.2\%, fibrates 5.3\%, oral antidiabetics 4.3\%; proton pump inhibitors $10.9 \%$ Vitamin and mineral supplements represented $24.6 \%$ of the concomitant drugs.

DDls were detected in 109 patients (20.4\%); 26 (23.4\%) were considered potential weak interaction $73(67 \%)$ potential interaction, and $10(9 \%)$ contraindicated. In the latter, the potentiated protease inhibitor (darunavir/cobiscitat) is involved in $80 \%$ of cases with: budenoside (2 cases), quetiapine, bisoprolol, domperidone, phenitoine, midazolam, lercandipine. Rilpivirine was involved in 2 cases with: eslicarbazepine and omeprazole.

Qualitative cross-sectional survey of the new ART dispensing model. Table 2 describes the results gathered from the satisfaction questionnaire $(n=533)$. At the time of the survey, $49.2 \%(262 / 533)$ of patients had visited the community pharmacy at least 3 times to collect ART, 40.2\% (214/533) 2 times, and only 6.8\% (36/533) once. Most of the patients (71.9\% (383/533)) were very satisfied and preferred to go to the community pharmacy to collect ART (406: 76.2\%); the mean score was 9.3 (DS: 1.4) on a scale of 1 to 10 points, with 10 being the maximum satisfaction. The benefits reported by the patients were: 1) proximity to home (406: 76.1\%); 2) 


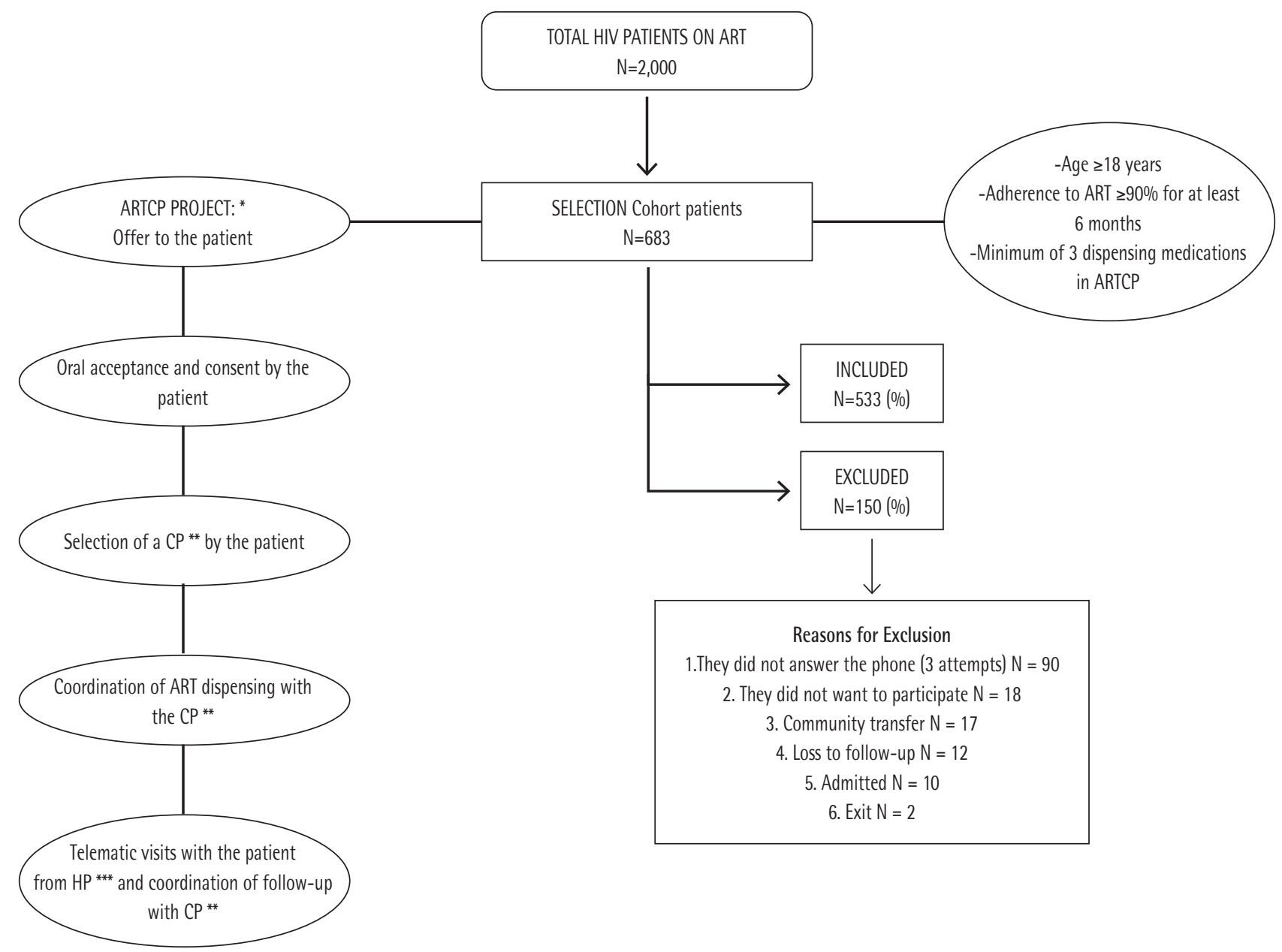

\begin{tabular}{l|l} 
Figura 1 & Flowchart: Patient selection and ART dispensing circuit integrating the community pharmacy (ATRCP).
\end{tabular}

* ARTCP: antiretroviral treatment based on community pharmacy; ART: antiretroviral treatment

${ }^{*} \mathrm{CP}$ : community pharmacy

${ }^{* * *}$ HP: Hospital Pharmacy

lower risk of contagion of COVID-19 (318: 59.66\%); 3) shorter waiting time (201: $37.1 \%)$; 4) time flexibility (104: 19.5\%); 5) reduction of expenses (especially for public transport) (35: $6.57 \%$ ). A total of $11(2 \%)$ patients reported no benefit. Most patients $(411 / 533 ; 77.1 \%)$ confirmed that they did not encounter any problems. The main limitations reported were: 1) lack of privacy preservation (65: 12.2\%); 2) lack of coordination in the organization (Hospital Pharmacy-Community Pharmacy (57: 10.7\%).

\section{DISCUSSION}

The approach to shared pharmaceutical care between community and hospital pharmacies in dispensing $\mathrm{OHM}$, with the leadership of the hospital pharmacy, is expanding into new practice settings and includes improved patient care services, especially for those with chronic diseases [12-14], and particularly in patients living with HIV $[15,16]$.

The integration of the community pharmacy into an ART dispensing program, coordinated from the hospital pharmacy, was conceived in response to the COVID-19 pandemic during the most restrictive confinement period, out of concern that patients would interrupt ART due to difficulties in travelling to the hospital, and for security reasons, avoiding overcrowding of patients in the hospital pharmacy and thus reducing the risk of spreading COVID-19. The present study describes the experience and can be considered successful. $71.9 \%$ of the patients were very satisfied and most of them preferred to continue 


\begin{tabular}{|c|c|c|}
\hline Table 1 & \multicolumn{2}{|c|}{ Participant's characteristics } \\
\hline Characteristi & & 533 \\
\hline Men, $n(\%$ & & $440(82.6)$ \\
\hline Women, $n$ & & $93(17.4)$ \\
\hline Mean, age & & $48.33(11.96)$ \\
\hline \multicolumn{3}{|c|}{ Ethnicity n (\%) } \\
\hline Caucasian & & $392(73.5)$ \\
\hline Hispanic & & $116(21.8)$ \\
\hline Arab & & $10(1.9)$ \\
\hline Asian & & $7(1.3)$ \\
\hline African & & $8(1.5)$ \\
\hline \multicolumn{3}{|c|}{ Toxic habits, n (\%) } \\
\hline Smoking & & $226(42.4)$ \\
\hline Alcohol ce & & $10(1.9)$ \\
\hline Consumpt & Irugs of abuse & $117(22)$ \\
\hline "Chem Sex & & $32(6)$ \\
\hline \multicolumn{3}{|l|}{ HIV } \\
\hline CD4T cells & edian (IOR) & $800(610-1008)$ \\
\hline Viral Supp & $<50$ copies / mL, n (\%) & $526(98.7)$ \\
\hline Detectabl & ween $20-100$ copies / mL, $n(\%)$ & $6(1.12 \%)$ \\
\hline Detectabl & 00 copies / mL, n (\%) & $1(0.19 \%)$ \\
\hline \multicolumn{3}{|c|}{ ATR characteristics, $n(\%)$} \\
\hline Monother & & $22(4.1)$ \\
\hline Biotherap & & $108(20.3)$ \\
\hline Triple the & & $401(75.2)$ \\
\hline \multicolumn{3}{|c|}{ Concomitant medication, n $(\%)$} \\
\hline Total pati & & $304(57)$ \\
\hline Polypharn & drugs & $89(16.7)$ \\
\hline DDls & & $109(20.5)$ \\
\hline
\end{tabular}

* DS: Standard deviation; IOR: Interquartile range; CV: viral load; DDls: Drug-drug interaction

with the implemented model. A low percentage of patients (14.8\%) stated that they were indifferent when choosing the service provider (Hospital Pharmacy versus Community Pharmacy), while only $9 \%$ preferred dispensing in the hospital environment. This indicates that the program has possibilities for improvement, in terms of confidentiality and coordination between pharmaceutical teams.

The findings of our study confirm the observations in the literature of the benefits reported, such as the flexible hours offered by the community pharmacy [17], and the easy access, both temporal and geographic [18] during the current health emergency. This demonstrates not only that the community

\begin{tabular}{|c|c|c|c|}
\hline \multirow{2}{*}{$\begin{array}{c}\text { Table } 2 \\
\text { Quality dimensions }\end{array}$} & \multicolumn{3}{|c|}{$\begin{array}{l}\text { Descriptive analysis of the results } \\
\text { of the satisfaction questionnaire: } \\
\text { ART dispensing model based on the } \\
\text { Community Pharmacy }(n=533)\end{array}$} \\
\hline & & Description & $n(\%)$ \\
\hline \multirow{3}{*}{\multicolumn{2}{|c|}{ 1. Degree of satisfaction }} & Very satisfied & $383(71.9 \%)$ \\
\hline & & Satisfied & $139(26.1 \%)$ \\
\hline & & Dissatisfied & $11(2.1 \%)$ \\
\hline \multirow{3}{*}{\multicolumn{2}{|c|}{$\begin{array}{l}\text { 2. Acceptance } \\
\text { (dispensing preference) }\end{array}$}} & Community Pharmacy & 406 (76.2) \\
\hline & & Hospital Pharmacy & $48(9 \%)$ \\
\hline & & Indifferent & $79(14.8 \%)$ \\
\hline \multirow{3}{*}{\multicolumn{2}{|c|}{$\begin{array}{l}\text { 3. Accessibility } \\
\text { (choice of community pharmacy) }\end{array}$}} & Pharmacy close to home & $453(85 \%)$ \\
\hline & & Pharmacy away from home & $41(7.7 \%)$ \\
\hline & & Indifferent & $39(7.3 \%)$ \\
\hline \multirow{4}{*}{\multicolumn{2}{|c|}{$\begin{array}{l}\text { 4. Score } \\
\text { (score from } 0 \text { to 10) }\end{array}$}} & $9-10$ & $379(71.1)$ \\
\hline & & $7-8$ & $138(25.9)$ \\
\hline & & $5-6$ & $10(1.9)$ \\
\hline & & $<5$ & $6(1.2)$ \\
\hline
\end{tabular}

pharmacy can participate in the dispensing of ART, but also that they can contribute to reduce the burden on the hospital health system [19]

The value of the clinical pharmacist as a member of a multidisciplinary HIV care team resulted in improvements in ART adherence [18], in the detection of DDIs, as well as in the quality of prescription and patient safety [20]. It would be interesting to carry out specific training in the area of patient care in ART for community pharmacists. Indeed, in the present study, $20.5 \%$ of DDIs that could be detected early were identified.

The main limitation of this study is that it was carried out in a cohort of stable HIV patients, with optimal adherence to ART (selected by computerized registries of the Hospital Pharmacy), therefore it is subject to selection bias. Specific studies would be required in patients with suboptimal adherence, or risk thereof (cultural barrier, social problem, psychiatric disorder) in order to evaluate whether community pharmaceutical care continues to offer the benefits and safety it has demonstrated in highly adherent patients.

The COVID-19 pandemic has valued shared pharmaceutical care between community and hospital pharmacy and will likely reveal new roles that they could play in our environment, beyond the pandemic.

\section{FUNDING}

None to declare 


\section{CONFLICTS OF INTEREST}

The authors declare no conflict of interest

\section{REFERENCES}

1. Koster ES, Philbert D, Bouvy ML. Impact of the COVID-19 epidemic on the provision of pharmaceutical care in community pharmacies. Res Soc Adm Pharm. 2021;17(1):2002-4.

2. Sum ZZ, Ow CJW. Community pharmacy response to infection control during COVID-19. A cross-sectional survey. Res Soc Adm Pharm. 2021;17(1):1845-52.

3. Giua C, Paoletti G, Minerba L, Malipiero G, Melone G, Heffler E, et al. Community pharmacist's professional adaptation amid COVID-19 emergency: a national survey on Italian pharmacists. Int J Clin Pharm. 2021;1-8.

4. Strand MA, Bratberg J, Eukel H, Hardy M, Williams C. Community Pharmacists' Contributions to Disease Management During the COVID-19 Pandemic. Prev Chronic Dis. 2020;17:E69.

5. Hirsch JD, Rosenquist A, Best BM, Miller TA, Gilmer TP. Evaluation of the first year of a pilot program in community pharmacy: HIV/ AIDS medication therapy management for Medi-Cal beneficiaries. J Manag Care Pharm. 2009;15(1):32-41.

6. Kibicho J, Owczarzak J. A patient-centered pharmacy services model of HIV patient care in community pharmacy settings: a theoretical and empirical framework. AIDS Patient Care. 2012;26(1):20-8.

7. Castillo E, Palepu A, Beardsell A, Akagi L, Yip B, Montaner JSG, et al. Outpatient pharmacy care and HIV viral load response among patients on HAART. AIDS Care. 2004;16(4):446-57.

8. Asieba IO, Oqua DA, Wutoh AA, Agu KA, Omeh OI, Adeyanju ZA, et al. Antiretroviral therapy in community pharmacies - Implementation and outcomes of a differentiated drug delivery model in $\mathrm{Ni}$ geria. Res Social Adm Pharm. 2021;17(5):842-849. doi: 10.1016/j. sapharm.2020.06.0259.

9. Avong YK, Aliyu GG, Jatau B, Gurumnaan R, Danat N, Kayode GA, et al. Integrating community pharmacy into community based anti-retroviral therapy program: A pilot implementation in Abuja, Nigeria. PLoS ONE 2018;13(1):e0190286. doi: 10.1371/journal. pone.0190286.

10. Cocohoba JM, Murphy P, Pietrandoni G, Guglielmo BJ. Improved antiretroviral refill adherence in HIV-focused community pharmacies. J Am Pharm Assoc. 2012;52(5):e67-73.

11. Liverpool HIV Interactions. [cited $14^{\text {th }}$ of February 2021]. Available at: https://www.hiv-druginteractions.org/

12. Barnett MJ, Frank J, Wehring $H_{1}$ Newland B, VonMuenster S, Kumbera $\mathrm{P}$, et al. Analysis of pharmacist-provided medication therapy management (MTM) services in community pharmacies over 7 years. J Manag Care Pharm. 2009;15(1):18-31.

13. Isetts BJ, Schondelmeyer SW, Artz MB, Lenarz LA, Heaton AH, Wadd $W B$, et al. Clinical and economic outcomes of medication therapy management services: the Minnesota experience. J Am Pharm Assoc. 2008;48(2):203-14.
14. Cranor CW, Bunting BA, Christensen DB. The Asheville Project: longterm clinical and economic outcomes of a community pharmacy diabetes care program. J Am Pharm Assoc. 2003;43(2):173-84.

15. Cocohoba J, Hsu T, Greenblatt RM. Community Pharmacy Use Patterns of Women with HIV and Women At Risk for HIV in the San Francisco Bay Area. J Pharm Technol. 2010;26(5):271-5.

16. Burde A, O'Connor S, Hachey D. Community Pharmacy Enhanced Dispensing Model to Improve Medication Access for Rural Patients Living with HIV. Innov Pharm. 2019;10(4):11.

17. Mugavero MJ, Norton WE, Saag MS. Health care system and policy factors influencing engagement in HIV medical care: piecing together the fragments of a fractured health care delivery system. Clin Infect Dis. 2011;52 Suppl 2:S238-246.

18. Kauffman $Y$, Nair $V$, Herist $K$, Thomas $V$, Weidle PJ. HIV medication therapy management services in community pharmacies. J Am Pharm Assoc. 2012;52(6):e287-91.

19. Kretchy IA, Asiedu-Danso M, Kretchy J-P. Medication management and adherence during the COVID-19 pandemic: Perspectives and experiences from low-and middle-income countries. Res Soc Adm Pharm. 2021;17(1):2023-6.

20. Molas E, Luque $S$, Retamero A, Echeverría-Esnal D, Guelar A, Montero $M$, et al. Frequency and severity of potential drug interactions in a cohort of HIV-infected patients Identified through a Multidisciplinary team. HIV Clin Trials. 2018;19(1):1-7. 
Gloria Martin-Saco

Alexander Tristancho

Antonina Arias

Isabel Ferrer

Ana Milagro

Juan M. García-Lechuz

\section{Mycoplasma genitalium and sexually transmitted infections: evidences and figures in a tertiary hospital}

Clinical Microbiology Department. Hospital Universitario Miguel Servet. Zaragoza. Spain.

Article history

Received: 21 June 2021; Revision Requested: 19 July 2021; Revision Received: 19 October 2021; Accepted: 29 October 2021;

Published: 17 December 2021

\section{ABSTRACT}

Introduction. Mycoplasma genitalium is an emerging cause of sexually transmitted infections (STIs) and has been implicated in non-gonococcal urethritis in men and cervicitis in woman. The aim of this study is determinate the incidence and pathogenicity of $M$. genitalium within the diagnosis of STIs detected from clinical samples in a third level hospital.

Material and methods. A total of 8,473 samples from endocervix, urethra, vagina, rectum and others were processed applying Allpex STI Essential Assay. More than 190 records were reviewed to determinate $M$. genitalium pathogenicity.

Results. M. genitalium was detected in a rate $2.8 \%$. Co-infections were detected in $20 \%$ of the patients.

Conclusions. M. genitalium is considered a STI emerging pathogen thanks to the renewal of multiplex-PCR tests although with a low incidence in our approach. Emerging from our experience and the institutional recommendations both detection of acid nucleic techniques (NAATs) and gonococcal culture might be implemented accurately and coexist to adequate prescriptions.

Keywords: Mycoplasma genitalium, sexually transmitted infections, coinfection
Mycoplasma genitalium en el renovado diagnóstico de las infecciones de transmisión sexual: evidencias y cifras en un hospital terciario

\section{RESUMEN}

Introducción. Mycoplasma genitalium es un patógeno emergente causante de infecciones de transmisión sexual (ITS) y se ha relacionado con uretritis no gonocócica en hombres y cervicitis en mujeres. El objetivo de este estudio es determinar la incidencia y patogenicidad de $M$. genitalium en el seno del diagnóstico de ITS detectadas a partir de muestras clínicas en un hospital terciario.

Métodos. Se procesaron 8.473 muestras de endocérvix, uretra, vagina, recto y otros, aplicando Allpex STI Essential Assay. Se revisaron más de 190 historias clínicas para determinar la patogenicidad de M. genitalium.

Resultados. Se detectó M. genitalium en 2,8\% de casos. Hubo coinfecciones en 20\% de los pacientes.

Conclusiones. M. genitalium a pesar de la baja incidencia en nuestra revisión, actualmente es un patógeno de valor en alza gracias al desarrollo de técnicas moleculares como PCRmultiplex. A partir de nuestra experiencia y las recomendaciones institucionales, tanto las técnicas de detección de ácidos nucleicos (NAATs) como los cultivos para gonococo deberían implementarse y coexistir para adecuar los tratamientos.

Palabras clave: Mycoplasma genitalium, infección de transmisión sexual, coinfección

\section{INTRODUCTION}

Mycoplasma genitalium is the smallest known self-replicating bacterium that cause non-gonococcal urethritis in men and cervicitis in women. Co-infections with M. genitalium and other bacterial sexually transmitted infections (STIS) have fre- 
quently reported. Its prevalence varies among sexually transmitted infection clinic attendees and the general population [1]. In our community, there is not a reference centre for attending STI patients and they are referred from Primary Care to specialities (dermatology, ginecology, infectious diseases) and directly to our microbiology lab at Miguel Servet Hospital (HUMS). The general purpose of this study was to determine the incidence and pathogenicity of $M$. genitalium within the STIs detected from clinical samples sent to our laboratory and discuss the renewal procedures and laboratory changes in the diagnosis of STI.

\section{MATERIAL AND METHODS}

A real-time PCR (Allplex STI Essential Assay by Seegene) was the detection method applied in vaginal, endocervical, and urethral samples. This assay detects simultaneously 7 microorganisms: Chlamydia trachomatis, Mycoplasma genitalium, Mycoplasma hominis, Neisseria gonorrhoeae, Trichomonas vaginalis, Ureaplasma parvum, Ureaplasma urealyticum. At the same time, samples were cultured on Columbia blood, Chocolate, VCA Neisseria gonorrhoeae and Sabouraud agar.

Antibiograms from positive cultures for Neisseria gonorrhoeae were done on GCll agar supplemented with Isovitalex (Becton-Dickinson) following the recommendations from EUCAST and using a control strain ATCC 49226.

From January 2019 to October 2020, 8,473 samples were processed from 6,058 patients. In this period, our hospital assisted a population of 586,835 inhabitants.

We reviewed the number of $M$. genitalium detected by PCR in this period and age, sex, co-infections and clinical evidence were analysed from the LIS records.

\section{RESULTS}

From 8,473 samples submitted to Allplex assay, M. genitalium was detected in $234(2.8 \%)$ from 232 patients (106 males; 126 females). The mean age was 29.8 years, being the group between 19 and 35 years old almost 70\% of the cases. Samples were from endocervix (103), urethra (84), vagina (18), urine (16), rectum (11), others (2).
From the review of 194 available clinical records about M. genitalium isolates, 43 (22\%) were clinically significant and were treated (52\% azithromycin, 32\% moxifloxacin, 16\% doxycycline). The median cycle threshold- (CT) was 25.3 in the infected group and 30.3 in the non-infected group. Therefore, during this period, the prevalence of $M$. genitalium was $0.07 \% 0$ and the incidence density rate was 3.8 new cases $/ 100$ patients/year.

The incidence rate of $N$. gonorrhoeae, $C$. trachomatis and $T$. vaginalis in the same period is presented in table 1. Despite the decrease in the number of samples in 2020 compared to the previous years, there was an 11\% of increase in the number of positive gonococcal cultures.

Co-infections were in 16/106 male patients with M. genitalium detected $(9 \mathrm{~N}$. gonorrhoeae, $6 \mathrm{C}$. trachomatis, $1 \mathrm{~T}$. vaginalis) and in 31/126 female patients (23 C. trachomatis, 5 T. vaginalis, 3 N. gonorrhoeae). M. genitalium was detected together with M. hominis (5) and U. urealyticum (4) with an uncertain value not clinically related.

\section{DISCUSSION}

M. genitalium is a considered pathogen but in our experience, the incidence was low and less than 25\% of patients with a positive sample was clinically significant and treated. Different consideration deserves the diagnosis of gonorrhoea established by the detection of $N$. gonorrhoeae at an infected site, either by nucleic acid amplification (NAATs) or by culture. Symptoms and signs of sexually acquired infection depend, in part, on the site of infection. One of the most important and scary pathogen, N. gonorrhoeae, is on an emerging trend since the last decade [2]. Co-existing infections such as $C$. trachomatis, T. vaginalis, M. genitalium, Candida albicans and conditions as bacterial vaginosis, are common and these should be considered for an optimal and efficacious treatment but its interpretation is often difficult [3].

The approach to diagnose any infectious diseases will be oriented by the clinical examination, but sexually transmitted diseases (STDs) need a more specific and in-depth oriented exam and interview of sexual behaviours [4].

Having fast NAAT tests allows a personalized, practical, preventive and predictive assistance. NAATs are more sensitive than culture, particularly for oropharyngeal and rectal

\begin{tabular}{l|cccc}
\hline Table 1 & \multicolumn{4}{|l}{$\begin{array}{l}\text { Prevalence and incidence rate of M. genitalium, } \\
\text { N. gonorrhoea, C. trachomatis and T. vaginalis } \\
\text { infections during the study period (2019-2020). }\end{array}$} \\
\hline & N. Cases & Population at risk & Prevalence \%o & Incidence rate \% \\
\hline M. genitalium & 43 & 6,058 & 0.07 & 0.7 \\
\hline N. gonorrhoea & 498 & 6,985 & 0.84 & 7.1 \\
C. trachomatis & 740 & 6,985 & 1.26 & 10.6 \\
\hline T. vaginalis & 186 & 6,985 & 0.32 & 2.7 \\
\hline
\end{tabular}


sites and they show high sensitivity (>95\%) in both symptomatic and asymptomatic infection but indirectly these tests promotes the detriment and oblivion of classical tests (rapid wet mount smear or Gram stain, special media cultures ...). So that, it is assumed that the primary role of culture is not for diagnostic purposes but for antimicrobial susceptibility testing prior to prescribe any treatment.

In the study of Salmeron et al. [5], a prospective multicentre study in ten hospitals in Spain (including ours), only 49\% of gonococcal infections had a positive culture available for antimicrobial susceptibility testing. Azithromycin resistance was found in 12\% and high-level resistance (MIC>256 mg/L) was detected in $0.1 \%$ of all cases. As long as antimicrobial resistance in $N$. gonorrhoeae continues spreading, cultures will survive. Despite the decrease in the number of samples and patients in 2020, we detected an 11\% of increase in the number of positive gonococcal cultures [6]. The rate of gonococcal resistance to azithromycin detected in our lab was between 19 and 24\% of the isolates and 64\% to ciprofloxacin. There was no isolate resistant to ceftriaxone. These are the reasons for the culture survival.

The detection of antimicrobial resistance genes enclosed in the multiplex PCR tests or the whole genome sequencing armamentarium threaten cultures to be banished. Nevertheless, the "multiplex" results of the NAATs must be interpreted cautiously, because bacteria as M. genitalium, M. hominis, U. urealyticum and $U$. parvum can pose confounding approaches, potential partner conflict and misuse of antibiotics. M. genitalium was detected in our study in a low rate $2.8 \%$ and a very low prevalence. From the review of near two hundred available clinical records, it was relevant in less than 25\% of patients and treated.

Co-infections pose another growing barrier for specific implementation of prevention strategies. In our study, coinfections were detected in 47 patients (20\%), mainly M. genitalium and $C$. trachomatis (29 cases), or $N$. gonorrhoeae (12 cases) or $T$. vaginalis ( 5 cases). In the article of Rob et al [7], the prevalence of co-infections in men who have sex with men (MSM) was significantly higher (20\%) than in heterosexual men and women (4.2\%), and it was significantly associated with HIV infection. Syphilis, HIV together with N. gonorrhoeae and C. trachomatis show how co-infections can be missed in rectal and pharyngeal localizations in asymptomatic patients, who can further spread these co-infections [7].

In agreement with the comments from Roland C. Merchant in Annals of Emergency Medicine [8], accurate pointof-care rapid tests would permit the more efficient use of antimicrobials and would reduce the inherent difficulties in attempting to notify patients of their test results after their emergency department visit.

Emerging from our experience and the institutional recommendations $[9,10]$, both NAATs and primary and following cultures need to live together in good harmony and fitness to prevent the blind prescriptions from spreading fatal errors.

In a recent article published by Dumke et al. [11], about some important strategies to establish regional networks of laboratories that can perform gonococcal culture and resistant gene detection of M. genitalium (quinolones and macrolides), they highlight the importance of a good quality control mechanisms to detect treatment failures by developing a standard protocol of follow-up.

Our study has the limitation of the small number of patients with enough clinical data an also the default of a long follow-up of asymptomatic patients (just 3 months in symptomatic) and their partners to know the real prevalence and clinical impact of M. genitalium. Nevertheless, we did not take into account the positive samples of asymptomatic patients in accordance with recent publications and guidelines [12-14]. Screening of asymptomatic $M$. genitalium infection among women and men or extragenital testing for M. genitalium is not recommended.

In conclusion, M. genitalium is considered a STI pathogen thanks to the renewal of multiplex-PCR tests although with a low incidence in our approach.

\section{FUNDING}

None to declare

\section{CONFLICTS OF INTEREST}

The authors declare no conflict of interest

\section{REFERENCES}

1. Taylor-Robinson D, Jensen JS. Mycoplasma genitalium: from Chrysalis to multicolored butterfly. Clin Microbiol Rev 2011; 24 (3):498-514. doi: 10.1128/CMR.00006-11.

2. Stary A. The Changing Spectrum of Sexually Transmitted Infections in Europe. Acta Derm Venereol 2020; 100: 242-247. doi: 10.2340/00015555-3470

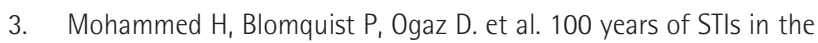
UK: a review of national surveillance data. Sex Transm Infect 2018; 94(8):553-558. doi: 10.1136/sextrans-2017-053273.

4. Workowski KA, Berman S. Sexually transmitted diseases treatment guidelines, 2010. MMWR Recomm Rep. 2010; 59(RR-12):1-110.

5. Salmerón $P$, Viñado $B$, Arando $M$ et al. Neisseria gonorrhoeae antimicrobial resistance in Spain: a prospective multicentre study. J Antimicrob Chemother 2021;doi:10.1093/jac/dkab037.

6. Martin G, Tristancho A, Milagro A et al. Mycoplasma genitalium: evidences and figures in a tertiary hospital in Spain. Abstract 00845 ECCMID Viena 2021.

7. Rob F, Jůzlová K, Kružicová Z et al. Prevalence of Chlamydia trachomatis and Neisseria gonorrhoeae co-infections among patients with newly diagnosed syphilis: a single-centre, cross-sectional study. Cent Eur J Public Health 2019; 27(4):285-291

8. Merchant RC. Infectious disease. Update on emerging infections: news from the Centers for Disease Control and Prevention. Ann Emerg Med 2011; 58(1):67-8. 
9. MMWR Recomm Rep. Recommendations for the laboratory-based detection of Chlamydia trachomatis and Neisseria gonorrhoeae-2014; 63(RR-02):1-19.

10. WHO. Multi-drug resistant gonorrhoeae. Newsletter. 6th Nov 2020. www.who.int/news-room/fact-sheets/detail/multi-drug-resistant-gonorrhoeae

11. Dumke R, Ziegler T, Abbasi-Boroudjeni N, Rust M, Glaunsinger T. Prevalence of macrolide- and fluoroquinolone-resistant Mycoplasma genitalium strains in clinical specimens from men who have sex with men of two sexually transmitted infection practices in Berlin, Germany. J Glob Antimicrob Resist 2019; 18:118-121. doi: 10.1016 /j.jgar.2019.06.015.

12. Kirby T. Mycoplasma genitalium: a potential new superbug. Lancet Infect Dis 2018; 18: 951-952. doi: 10.1016/S1473-3099(18)30506-

1

13. Gnanadurai R, Fifer H. Mycoplasma genitalium: A Review. Microbiology 2020; 166: 21-29. doi: 10.1099/mic.0.000830.

14. Workowski KA, Bachmann LH, Chan PA et al. Sexually Transmitted Infections Treatment Guidelines, 2021. US Department of Health and Human Services/Centers for Disease Control and Prevention. MMWR Recomm Rep. 2021;70(4):1-187. doi: 10.15585/mmwr. rr7004a1. 
Saray Mormeneo Bayo Miguel Moreno Hijazo, María Pilar Palacián Ruíz María Cruz Villuendas Usón

\section{Impacto del SARS-CoV-2 en el diagnóstico de bacteriemia comunitaria en un hospital terciario}

Servicio de Microbiología. Hospital Universitario Miguel Servet Zaragoza. España

Article history

Received: 16 June 2021; Revision Requested: 5 October 2021; Revision Received: 17 October 2021; Accepted: 4 November 2021; Published: 5 January 2022

\section{RESUMEN}

Objetivo. Realizar un análisis de las bacteriemias diagnosticadas en urgencias durante el año 2020, coincidiendo con el periodo de la pandemia

Métodos. Estudio retrospectivo en un hospital de tercer nivel en España durante el período COVID del 4 de marzo al 31 de diciembre de 2020.

Resultados. El número de pacientes atendidos en urgencias durante el periodo de estudio y el número de hemocultivos extraídos sufrieron un descenso del $46,79 \%$ y del $35.7 \%$ respecto al mismo periodo de $2019(p<0.05)$. Se produjeron 320 bacteriemias mientas que en 2019 se produjeron 507, suponiendo un descenso del 36,8\% $(p<0,05)$. La tasa de positividad de los hemocultivos fue del 7,09\% en 2020 y del 7,23 \% en 2019 y la tasa de contaminación del 7,07 \% en 2020 y 5,67 \% en 2019. El microorganismo más frecuente aislado fue Escherichia coli, seguido de Staphylococcus aureus y de Klebsiella pneumoniae. El 6,62\% de los E. coli aislados fueron portadores de beta-lactamasas de espectro extendido (BLEE). EI porcentaje de $S$. aureus resistente a meticilina fue de 12,9 \% y el de K. pneumoniae BLEE fue del 11,54\%.

Conclusión. Durante la pandemia por SARS-CoV-2 se ha producido una disminución en el número de diagnósticos de bacteriemia, es posible que la atención estuviera centrada especialmente en la COVID descuidando otras enfermedades, como es el caso de la bacteriemia.

Palabras clave: bacteriemia comunitaria, SARS-CoV-2
Impact of SARS-COV-2 on the diagnosis of community bacteremia in a tertiary hospital

\section{ABSTRACT}

Objective. We carry out an analysis of the bacteremia diagnosed in the Emergency Department during 2020, coinciding with the period of the pandemic.

Method. We performed a retrospective analysis from March 4, 2020 to December 31, 2020.

Results. The number of patients who went to the Emergency Department during the study period and the number of extracted blood cultures decreased by $46.79 \%$ and $35.7 \%$ compared to the same period in 2019 ( $p<0.05)$. 320 bacteremia occurred while 507 occurred in 2019, assuming a decrease of $36.8 \%$ ( $p<0.05)$. The positivity rate of blood cultures was $7.09 \%$ in 2020 and $7.23 \%$ in 2019 and the contamination rate was $7.07 \%$ in 2020 and 5.67\% in 2019. The most frequently isolated microorganism was Escherichia coli, followed by Staphylococcus aureus and Klebsiella pneumoniae. A 6.62\% of the isolated $E$. coli were carriers of extended-spectrum beta-lactamases (ESBL). The percentage of methicillin-resistant $S$. aureus was $12.9 \%$ and that of $K$. pneumoniae ESBL was $11.54 \%$

Conclusion. During the SARS-CoV-2 pandemic there has been a decrease in the number of bacteremia diagnoses, it is possible that attention was focused especially on COVID, forgetting other diseases, such as bacteremia.

Key words: community bacteremia, SARS-CoV-2

\section{INTRODUCCIÓN}

Las bacteriemias de origen comunitario son aquellas que se detectan dentro de las primeras 48 horas de hospitalización. Están causadas mayoritariamente por bacterias gramnegativas, siendo el foco principal la orina seguido del respiratorio [1]. La 
bacteriemia es una entidad clinica que ocasiona una importante y creciente morbimortalidad y sigue suponiendo un importante problema de salud pública [2].

El nuevo coronavirus SARS-CoV-2 puede dar clínica muy variada, siendo la fiebre un sintoma relativamente frecuente [3]. No obstante, en todo paciente con fiebre la extracción de hemocultivos está recomendada para descartar bacteriemia.

El objetivo de este trabajo consiste en realizar un análisis de las bacteriemias diagnosticadas en urgencias durante el año 2020, coincidiendo con el periodo de la pandemia.

\section{MATERIAL Y MÉTODOS}

Se realizó un estudio retrospectivo de todos los hemocultivos recibidos desde urgencias del Hospital Universitario Miguel Servet en Zaragoza, en pacientes con edad igual o superior a 18 años desde el periodo comprendido entre el 4 de marzo (primer positivo en Aragón) al 31 de diciembre de 2020. Se recogieron los mismos datos del año anterior.

Se definió un hemocultivo como contaminado cuando se aisló alguno de estos microorganismos en una única extracción de dos o más hemocultivos: Micrococcus spp., Staphylococcus coagulasa negativo, Streptococcus del grupo viridans, Propionibacterium acnes, Corynebacterium spp. y Bacillus spp [4].

El análisis estadistico se realizó mediante el programa IBM SPSS 19. Las diferencias entre grupos en variables continuas se analizaron mediante la prueba de U de Mann-Whitney cuando se trataron de dos grupos y mediante análisis de la varianza de un factor (ANOVA) cuando se trataron más de dos grupos.

\section{RESULTADOS}

El número de pacientes que fueron atendidos en urgencias de nuestro hospital durante el periodo de estudio fue de 80.263 y de 117.820 en el mismo periodo de 2019, representando un $46,79 \%$ de descenso $(p<0.05)$.

En relación al número de hemocultivos extraidos en urgencias, se extrajeron 4.517 durante el periodo COVID mientras que en el mismo periodo de 2019 fueron 7.014, representando un $35.7 \%$ de descenso $(p<0.05)$, no hallándose diferencias significativas entre los distintos meses ( $p=0.998)$. El mayor descenso se observó durante abril y mayo. La figura 1 representa el número de hemocultivos procesados del 4 de marzo al 31 de diciembre de 2019 y 2020 por meses.

Durante el periodo de estudio se produjeron 320 bacteriemias mientas que en 2019 se produjeron 507, suponiendo un descenso del $36.8 \%(p<0.05)$. La media de edad fue de 73,66 años en 2020 y 74,00 en 2019 ( $p=0.429$ ). El porcentaje de hombres y mujeres fue respectivamente de $61,9 \%$ y $38,1 \%$ en 2020 y de $57,4 \%$ y $42,6 \%$ en 2019. La tasa de positividad de los hemocultivos fue muy similar siendo del $7.09 \%$ en 2020 y del $7.23 \%$ en 2019 y la tasa de contaminación del $7.07 \%$ en 2020 y $5.67 \%$ en 2019.

\begin{tabular}{l|cc}
\hline Tabla 1 & \multicolumn{2}{|c}{$\begin{array}{l}\text { Etiología de la bacteriemia comunitaria } \\
\text { por años, según los microorganismos } \\
\text { recogidos por el grupo EARS-net }\end{array}$} \\
\hline Microorganismo & $2020 \mathrm{n}(\%)$ & $2019 \mathrm{n}(\%)$ \\
$\mathrm{n}=320$ & $\mathrm{n}=507$ \\
\hline Escherichia coli & $151(47,2 \%)$ & $227(44,8 \%)$ \\
\hline Staphyloccocus aureus & $31(9,7 \%)$ & $38(7,5 \%)$ \\
\hline Klebsiella pneumoniae & $26(8,1 \%)$ & $44(8,7 \%)$ \\
\hline Enterococcus faecalis & $19(5,9 \%)$ & $13(2,6 \%)$ \\
\hline Streptococcus pneumoniae & $10(3,1 \%)$ & $28(5,5 \%)$ \\
\hline Enterobacter cloacae complex & $10(3,1 \%)$ & $9(1,8 \%)$ \\
\hline Pseudomonas aeruginosa & $9(2,8 \%)$ & $24(4,7 \%)$ \\
\hline Enterococcus faecium & $8(2,5 \%)$ & $4(0,8 \%)$ \\
\hline Proteus mirabilis & $7(2,2 \%)$ & $16(3,2 \%)$ \\
\hline Klebsiella oxytoca & $7(2,2 \%)$ & $8(1,6 \%)$ \\
\hline Streptococcus agalactiae & $5(1,6 \%)$ & $7(1,4 \%)$ \\
\hline Otros & $37(11,6 \%)$ & $89(17,6 \%)$ \\
\hline
\end{tabular}

Tanto en 2020 como en 2019, el microorganismo que con más frecuencia se aisló fue $E$. coli, seguido de $S$. aureus (el tercero en frecuencia en 2019). K. pneumoniae fue el tercer microorganismo en 2020 y el segundo en 2019. La tabla 1 representa los principales microorganismos causantes de bacteriemia comunitaria por año.

Respecto a las resistencias, el 6.62\% de los E. coli aislados fueron portadores de beta-lactamasas de espectro extendido (BLEE) en 2020 y del $11.89 \%$ en 2019. El porcentaje S. aureus resistente a meticilina fue de $12.9 \%$ en 2020 y de $31.58 \%$ en 2019. El porcentaje de $K$. pneumoniae BLEE fue del $11.54 \%$ en 2020 y del $2.27 \%$ en 2019.

\section{DISCUSIÓN}

Durante el periodo de estudio se produjo un importante descenso en el número de hemocultivos que podría atribuirse a la disminución en el número de pacientes que acudieron al servicio de urgencias.

Una de las medidas implantadas durante la pandemia fueron las consultas por vía telefónica en los centros de atención primaria. Es posible que en pacientes con fiebre la atención se focalizara en si el paciente sufría la COVID, recomendando aislamiento domiciliario y descuidando asi otras causas de fiebre como la bacteriemia. Además, el miedo a contraer la enfermedad pudo contribuir a que los pacientes estuvieran más tiempo en casa a pesar de sintomatología. Estas dos situaciones podrian explicar por qué disminuyó el volumen de hemocultivos extraídos respecto al año anterior.

El microorganismo que con más frecuencia se aisló fue $E$. coli tanto en 2020 como 2019, datos que van en consonancia 


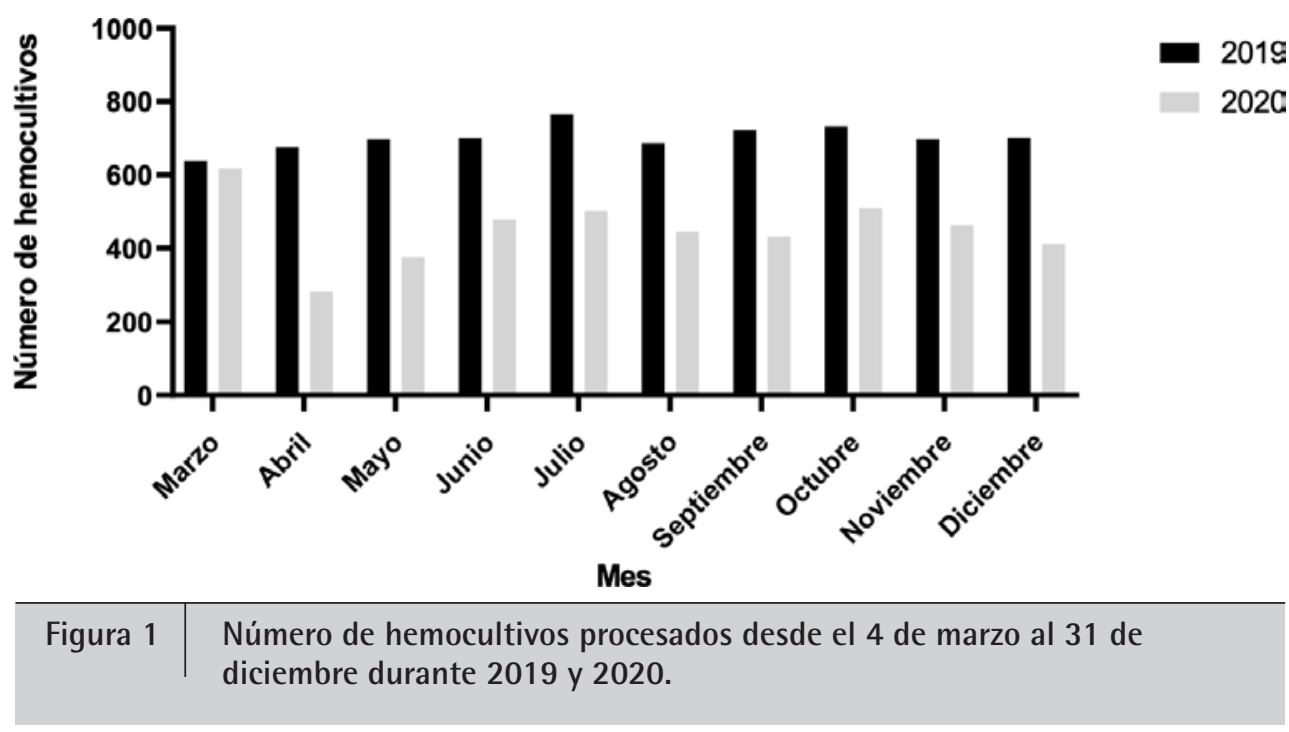

con otros estudios publicados $[1,5,6]$. Respecto a las resistencias se produjo un aumento de las bacteriemias por K. pneumoniae BLEE respecto a 2019, pero las bacteriemias por E. coli BLEE y $S$. aureus resistente a meticilina disminuyeron respecto a 2019.

La tasa de positividad de los hemocultivos se mantuvo constante durante los dos años estudiados, en torno al 7\%. al igual que Coburn et al. en su estudio [7]. La tasa de contaminación fue superior durante el periodo COVID, este hecho podria explicarse por la no familiaridad del personal sanitario con los equipos de protección individual (EPIs) así como por la alta rotación del personal que se produjo durante la pandemia. Según la Guía IDSA del 2018, la contaminación de los hemocultivos se considera un indicador de la calidad asistencial y no debería sobrepasar el 3\% de los hemocultivos totales recibidos en un laboratorio [8]. En nuestro estudio, tanto en 2019 como en 2020 la tasa de contaminación superó el 3\%, por lo que sería necesario hacer un estudio más minucioso para dilucidar las causas.

Recientemente hemos podido demostrar la etiología y el origen de la bacteriemia en pacientes atendidos con COVID-19 (sobre todo de tipo nosocomial asociada al uso de catéter) y en pacientes sin COVID-19 (fundamentalmente comunitaria y causada principalmente por E. coli) [9].

La mortalidad asociada a bacteriemia es elevada y el pronóstico mejora con un diagnóstico y tratamiento rápido [10]. La pandemia ha tenido un importante impacto en la asistencia sanitaria ya que los recursos asistenciales pre-pandemia han tenido que dar respuesta tanto a las patologías habituales como al exceso de demanda asistencial generada por la COVID; esta situación de estrés ha impactado de forma negativa en la calidad de la asistencia sanitaria.

La pandemia ha provocado bajas en el personal sanitario disponible por estar en aislamiento, desconcierto y falta de organización ante un escenario desconocido (escasez de EPIs, nuevos circuitos en el ámbito hospitalario, desconocimiento del curso de la enfermedad y su manejo, derivación de pacientes desde Atención Primaria a raíz de consultas telefónicas, etc.). Todo ello ha contribuido a la reducción y a la demora en el diagnóstico de bacteriemia.

\section{FINANCIACIÓN}

Los autores declaran que no han recibido financiación para la realización de este trabajo.

\section{CONFLICTO DE INTERÉS}

Los autores declaran no tener ningún conflicto de intereses.

\section{BIBLIOGRAFÍA}

1. Martínez Pérez-Crespo PM, López-Cortés LE, Retamar-Gentil P, García JFL, Vinuesa García D, León E, Calvo JM et al. PROBAC REIPI/GEIH-SEIMC/SAEI Group. Epidemiologic changes in bloodstream infections in Andalucia (Spain) during the last decade. Clin Microbiol Infect. 2021;27(2):283.e9-283.e16. doi: 10.1016/j. cmi.2020.05.015

2. Goto M, Al-Hasan MN. Overall burden of bloodstream infection and nosocomial bloodstream infection in North America and Europe. Clin Microbiol Infect. 2013;19(6):501-509. doi: 10.1111/14690691.12195

3. Ozma MA, Maroufi P, Khodadadi E, Köse , Esposito I, Ganbarov K et al. Clinical manifestation, diagnosis, prevention and control of SARS-CoV-2 (COVID-19) during the outbreak period. Infez Med. 2020; 28(2):153-165. PMID: 32275257

4. Dargère $S$, Cormier $H$, Verdon R. Contaminants in blood cultures: importance, implications, interpretation and prevention. Clin Microbiol Infect. 2018; 24(9):964-969. doi: 10.1016/j.cmi.2018.03.030 
5. Mora-Rillo $M$, Fernández-Romero $N$, Navarro-San Francisco $C$, Díez-Sebastián J, Romero-Gómez MP, Fernández FA, et al. Impact of virulence genes on sepsis severity and survival in Escherichia coli bacteremia. Virulence. 2015;6(1):93-100. doi: 10.4161/21505594.2014.991234.

6. Kosai K, Yamagishi Y, Hashinaga K, Nakajima K, Mikamo H, Hiramatsu $K$, Takesue $Y$, Yanagihara K. Multicenter surveillance of the epidemiology of gram-negative bacteremia in Japan. J Infect Chemother. 2020;26(3):193-198. doi: 10.1016/j.jiac.2019.11.003.

7. Coburn B, Morris AM, Tomlinson G, Detsky AS. Does this adult patient with suspected bacteremia require blood cultures? JAMA. 2012;308(5):502-511. doi: 10.1001/jama.2012.8262.

8. Miller JM, Binnicker MJ, Campbell S, Carroll KC, Chapin KC, Gilligan $\mathrm{PH}_{1}$ et al. A Guide to Utilization of the Microbiology Laboratory for Diagnosis of Infectious Diseases: 2018 Update by the Infectious Diseases Society of America and the American Society for Microbiology. Clin Infect Dis. 2018:31;67(6):e1-e94. doi: 10.1093/cid/ ciy381.

9. Mormeneo Bayo S, Palacián Ruiz M, Moreno Hijazo M, Villuendas Usón M. Bacteremia during COVID-19 pandemic in a tertiary hospital in Spain. Enfermedades Infecciosas y Microbiología Clínica. 2021:11;S0213-005X(21)00037-9. doi: 10.1016/j.eimc.2021.01.015

10. Candel F.J., Borges Sá M., Belda S., Bou G., Del Pozo J.L., Estrada 0. Current aspects in sepsis approach. Turning things around. Rev Esp Quimioter. 2018;31:298-315. 
Celia Roig Marti ${ }^{1}$ José Javier Jiménez Sierra² Ignacio Pérez Catalán ${ }^{1}$ Barbará Gomila Sard ${ }^{3}$ Alejandro Cardenal Álvarez' María Dolores Bellés Medall ${ }^{2}$

\section{Manejo de afectación cutánea y sistémica por Candida auris}

'Servicio de Medicina Interna. Hospital General Universitario de Castellón. Castellón. España.

${ }^{2}$ Servicio de Farmacia Hospitalaria. Hospital General Universitario de Castellón. Castellón. España.

${ }^{3}$ Servicio de Microbiología. Hospital General Universitario de Castellón. Castellón. España.

Article history

Received: 4 May 2021; Revision Requested: 12 September 2021; Revision Received: 11 October 2021; Accepted: 18 0ctober 2021; Published: 30 November 2021

\section{Estimado Editor:}

Paciente de 73 años que ingresa en Cirugía por hernia inguinal incarcerada con peritonitis polimicrobiana difusa precisando cirugía urgente y tratamiento con meropenem y linezolid. Presenta un postoperatorio complicado requieriendo ingreso en unidad de cuidados intensivos (UCI), donde se observa evolución tórpida de herida quirúrgica, necesitando nuevo ciclo de antibioterapia con piperacilina-tazobactam. Al mes, se da de alta a Medicina Interna (MIN), precisando nutrición parenteral (NP) con Catéter venoso central (CVC), y con estudio de colonización positivo para Candida auris en muestras axilar y rectal. Transcurridos cinco dias se objetiva pico febril, se remiten hemocultivos que tras positivizar en 24 horas y observarse levaduras en la tinción de Gram, con el fin de obtener un diagnóstico rápido, se decide realizar una PCR multiplex (Biofire ${ }^{\circledR}$ BCID2 (Filmarray ${ }^{\circledR}$ )) que detecta C. auris. De esta manera, se inicia tratamiento intravenoso (IV) con anfotericina B liposomal $400 \mathrm{mg}(5 \mathrm{mg} / \mathrm{kg} / \mathrm{d})$ y anidulafungina $200 \mathrm{mg}$ el primer día seguidos de $100 \mathrm{mg} / 24 \mathrm{~h}$ hasta 7 dias después de la negativización de los primeros hemocultivos, manteniendo anidulafungina hasta cumplir dos semanas desde la negativización (3-4 semanas en total de tratamiento). Al detectarse la candidemia se remite punta de CVC que se siembra utilizando la técnica de Maki y tras 48h de incubación, el cultivo resulta positivo para $C$. auris, además se realiza ecocardiografía transtorácica y fondo de ojo que son negativos. Paralelamente aparecen en escroto y pliegue inguinal y axilar, lesiones parcheadas eritematosas y maceradas con pequeñas pústulas satélites. En escroto se detecta ulceración superficial con pústulas blanquecinas sugestivas de lesiones micóticas (Figura 1), aislándose C. auris.

A las 48-72h de iniciar tratamiento, se consigue la defervescencia y la negativización de los hemocultivos, no obstante

Correspondencia:

Celia Roig Marti

Servicio de Medicina Interna. Hospital General Universitario de Castellón. Castellón. España. E-mail: celia.roig.marti@gmail.com

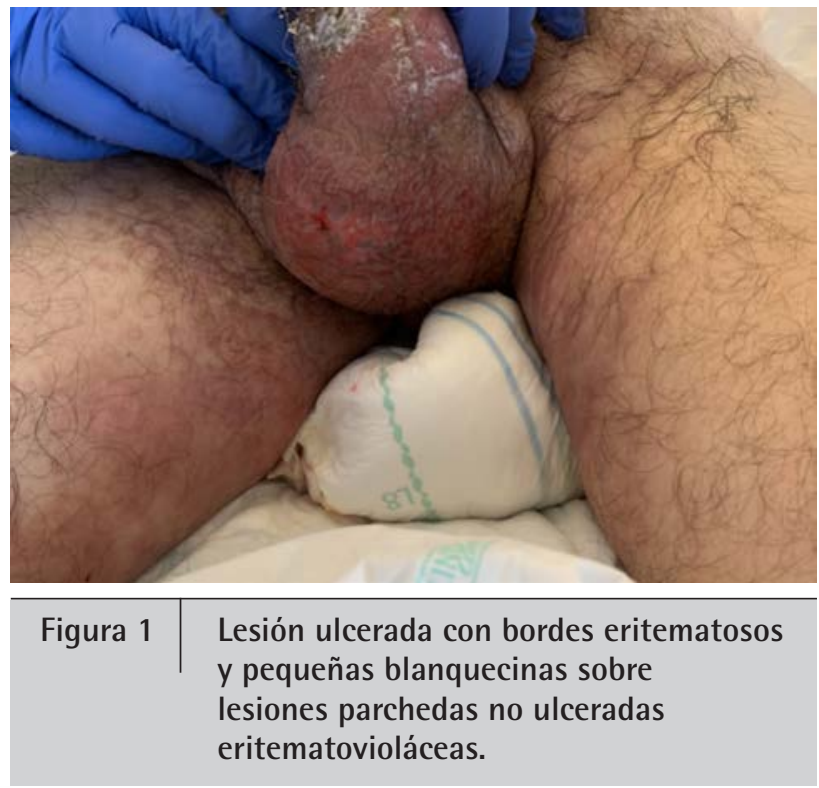

la evolución de las lesiones cutáneas no fue la esperable, es pues que se planteó la necesidad de un tratamiento tópico coadyuante. En este contexto, se valora de forma multidisciplinar con el servicio de farmacia (SF) y microbiología, generar una fórmula magistral de nistatina tópica. Se había realizado estudio de sensibilidad de la cepa aislada en sangre, aunque la nistatina no se incluía en el panel (Sensititre ${ }^{\odot}$ YeastOne $^{\odot}$ Y09). El SF elabora un gel de base hidrófila con carboximetilcelulosa sódica (CMCs) como agente gelificante a una concentración del 6\%, obteniendo buena consistencia y una acción superficial del fármaco sin efecto emoliente de la base, disminuyendo la humedad en los pliegues facilitando la resolución completa de las lesiones [4]. Se formula a una concentración del 1,5\% de nistatina, y se estudia cualitativamente la homogeneidad, propiedades organolépticas, evanescencia, extensibilidad y poder refrescante. Se otorga un periodo de validez de 30 días 


\begin{tabular}{|c|c|c|}
\hline Tabla 1 & \multicolumn{2}{|c|}{$\begin{array}{l}\text { Fórmula magistral de nistatina tópica. } \\
\text { Composición y metodología }\end{array}$} \\
\hline \multicolumn{3}{|c|}{ Fase 1. Elaboración del hidrogel de carboximetilcelulosa sódica al 6\% } \\
\hline \multicolumn{2}{|c|}{ Carboximetilcelulosa sódica (Acofarma ${ }^{\circledR}$ ) } & $6 \mathrm{~g}$ \\
\hline \multicolumn{2}{|l|}{ Glicerol } & $30 \mathrm{~g}$ \\
\hline \multicolumn{2}{|c|}{ Agua conservans } & $64 g$ \\
\hline \multicolumn{3}{|c|}{ Fase 2. Elaboración del hidrogel de nistatina al 1,5\% } \\
\hline \multicolumn{2}{|c|}{ Nistatina (Fagron ${ }^{\circledR}$ ) } & $0,675 \%$ \\
\hline \multicolumn{2}{|c|}{ Propilenglicol } & $14,25 \mathrm{~g}$ \\
\hline \multicolumn{2}{|c|}{ Hidrogel de carboximetilcelulosa al $6 \%$} & $30,1 \mathrm{~g}$ \\
\hline \multicolumn{3}{|c|}{ Modus operandi: } \\
\hline \multicolumn{3}{|c|}{$\begin{array}{l}\text { 1. Adicionar la carboximetilcelulosa sódica (CMCs) al mortero, añadir el glicerol y } \\
\text { mezclar con el pistilo obteniendo una dispersión homogeneizada. }\end{array}$} \\
\hline \multicolumn{3}{|c|}{$\begin{array}{l}\text { 2. Pesar } 64 \mathrm{~g} \text { de agua conservans en un vaso de precipitados de } 100 \mathrm{~mL} \text {. y calentar } \\
\text { hasta } 50^{\circ} \mathrm{C} \text {. Adicionar la dispersión de CMCs y glicerol al agua conservans y } \\
\text { mezclar con el agitador magnético hasta obtener un gel viscoso y homogéneo, y } \\
\text { dejar enfriar. }\end{array}$} \\
\hline \multicolumn{3}{|c|}{$\begin{array}{l}\text { 3. Pulverizar la nistatina en el mortero hasta obtener un polvo fino y disolverla } \\
\text { con propilenglicol. }\end{array}$} \\
\hline \multicolumn{3}{|c|}{$\begin{array}{l}\text { 4. Pasar la cantidad correspondiente de hidrogel de carboximetilcelulosa al } 6 \% \\
\text { en un vaso de precipitados de } 100 \mathrm{~mL} \text {, adicionar la disolución de nistatina y } \\
\text { propilenglicol agitando con la varilla de vidrio hasta que se disuelva por completo } \\
\text { en el gel. }\end{array}$} \\
\hline \multicolumn{3}{|c|}{ 5. Envasar en un tubo de aluminio y etiquetar. } \\
\hline
\end{tabular}

según la matriz de riesgo de preparaciones no estériles [5], y se analizan estos parámetros una vez a la semana durante el periodo de validez establecido. Se envasa en tubo de aluminio y se conserva en nevera. En la tabla 1 se detalla la composición y metodología.

Una vez elaborado el gel, se inicia tratamiento aplicándose 2 veces al dia durante 10 días con resolución completa de las lesiones y sin observar reacciones adversas. De forma paralela, el paciente mejora globalmente sin complicaciones por lo que es dado de alta.

C. auris es una levadura multirresistente productora de infecciones de elevada mortalidad (hasta un 60\% en algunas series) $[1,2]$. Fue aislada por primera vez en Japón en 2009 y desde entonces, se ha expandido mundialmente $[2,3]$. Es responsable de brotes intrahospitalarios de dificil control y manejo, que suponen una amenaza para el sistema de salud. Se trata de una levadura oval que forma colonias nacaradas en CHROM-agar-Candida [6], y que se caracteriza por su resistencia intrínseca a fluconazol (90\% de las cepas) [1]. En nuestro caso, el estudio de sensibilidad muestra resistencia a azoles con sensibilidad a equinocandinas (CMI de 0,06 y $0.125 \mathrm{mg} / \mathrm{L}$ para caspofungina y anidulafungina respectivamente), y a anfotericina B (CMI de $1 \mathrm{mg} / \mathrm{L})$.

La identificación de C. auris es compleja y su determi- nación, se realizó por la técnica de espectrometría de masas MALDI-TOF (matrix-assisted laser desorption ionization-time of flight mass spectometry), caracterizada por su rapidez diagnóstica, permitiendo inicio temprano del tratamiento y mejorando el pronóstico del paciente [6].

El paciente fue expuesto a varios ciclos de antibioterapia de amplio espectro y a procedimientos invasivos (CVC con NPT, sondaje vesical, cirugía...etc.) generando todo esto, un ambiente idóneo de inmunodepresión y predisposición para infecciones nosocomiales por microorganismos multirresistentes, entre otras la infección sistémica por C. auris [7].

En base al antifungigrama se inició biterapia con equinocandina y anfotericina $B$, teniendo en cuenta que los centros para el control y prevención de enfermedades (CDC) plantean iniciar tratamiento con anidulafungina, y en caso de ineficacia terapéutica (ausencia de respuesta o fungemia persistente) asociar anfotericina B [8]. No obstante, según la guía Mensa se desconoce el tratamiento óptimo, indicando la asociación de isavuconazol o posaconazol con anfotericina B liposomal o con una equinocandina [9]. Nuestro caso, fue un paciente frágil con gran probabilidad de fracaso terapéutico, por lo que se decidió retirar el CVC e iniciar biterapia, consiguiendo la defervescencia y la negativización de los hemocultivos en las primeras $48-72 \mathrm{~h}$. Con respecto al tratamiento tópico de la afectación cutánea de $\mathrm{C}$. auris, están indicados varios antifúngicos tópicos entre ellos nistatina $[9,10]$, no obstante, dada la ausencia de presentación comercial se elaboró la fórmula magistral para su aplicación. Aunque de forma paralela a la administración del hidrogel se administraba el tratamiento sistémico, inicialmente no se objetivó mejoría de las lesiones con el tratamiento endovenoso, es por ello que se planteó la necesidad de asociar un tratamiento tópico. El trabajo multidisciplinar entre los diferentes servicios ha sido imprescindible para conseguir la identificación e instauración precoz del tratamiento y la elaboración de un gel poco común como adyuvancia al tratamiento sistémico consiguió la resolución total de la afectación cutánea por C. auris.

\section{FINANCIACIÓN}

Los autores declaran no haber recibido financiación para la realización de este estudio.

\section{CONFLICTO DE INTERESES}

Los autores declaran no tener ningún conflicto de intereses.

\section{BIBLIOGRAFÍA}

1. Eldesouky HE, Li X, Abutaleb NS, Mohammad H, Seleem MN. Synergistic interactions of sulfamethoxazole and azole antifungal drugs against emerging multidrug-resistant Candida auris. Int J Antimicrob Agents. 52(6):754-761. doi: 10.1016/j.ijantimicag.2018.08.016. 
2. Garcia CS, Palop NT, Bayona JVM, Garcia MM, Rodríguez DN, Álvarez $\mathrm{MB}$, et al. Candida auris: report of an outbreak. Enferm Infecc Microbiol Clin (Engl Ed). 38 Suppl 1:39-44. English, Spanish. doi: 10.1016/j.eimc.2020.02.007.

3. Johns Hopkins: Bloomerg school of public health [internet]. 2019. Is Deadly Candida Auris a Product of Global Warming? [consultado el 25 de enero de 2021]. Disponible en: https://www.jhsph.edu/ news/news-releases/2019/is-deadly-candida-auris-a-product-ofglobal-warming.html

4. Punín E, Ballester A, Dávila C, Varela JJ, López MJ, Arias J, et al., Aspectos prácticos de la farmacotecnia en un servicio de farmacia, situación actual. Madrid: Master \&t Line prodigio; 2011. p. 219-244.

5. Ministerio de Sanidad, Servicios Sociales e Igualdad. Guía de buenas prácticas de preparación de medicamentos en servicios de farmacia hospitalaria [Internet]. 2014. [consultado el 10 de marzo de 2021]. Disponible en: https://www.sefh.es/sefhpdfs/GuiaBPP_JUNIO_2014_VF.pdf

6. Kathuria S, Singh PK, Sharma C, Prakash A, Masih A, Kumar A, Meis JF, Chowdhary A. Multidrug-Resistant Candida auris Misidentified as Candida haemulonii: Characterization by Matrix-Assisted Laser Desorption lonization-Time of Flight Mass Spectrometry and DNA Sequencing and Its Antifungal Susceptibility Profile Variability by Vitek 2, CLSI Broth Microdilution, and Etest Method. J Clin Microbiol. 53(6):1823-30. doi: 10.1128/JCM.00367-15.

7. Ruiz Gaitán AC, Moret A, López Hontangas JL, Molina JM, Aleixandre López Al, et al. Nosocomial fungemia by Candida auris: First four reported cases in continental Europe. Rev Iberoam Micol. 2017 Jan-Mar;34(1):23-27. doi: 10.1016/j.riam.2016.11.002.

8. CDC: Enfermedades fúngicas [Internet]. 2017. Recomendaciones para el tratamiento de Candida auris. [Consultado el 30 de enero de 2021]. Disponible en: http:// www.cdc.gov/fungal/candidaauris/es/c-auris-treatment.html

9. Mensa J, Soriano A, García J.E, Letang E, López E, Marco F, et al. Guía de terapéutica antimicrobiana. Barcelona: Antares; 2020

10. Taudorf EH, Jemec GBE, Hay RJ, Saunte DML. Cutaneous candidiasis - an evidence-based review of topical and systemic treatments to inform clinical practice. J Eur Acad Dermatol Venereol. 2019 Oct;33(10):1863-1873. doi: 10.1111/jdv.15782 
Fernando Berdugo Hurtado ${ }^{1}$ Emilio Guirao Arrabal ${ }^{2}$ Andrés Barrientos Delgado ${ }^{1}$ Antonio José Ruiz Rodriguez'

\section{SARS-CoV-2 infection presenting as acute acalculous cholecystitis}

'Servicio de Aparato Digestivo. Hospital Universitario Clínico San Cecilio. Granada.

${ }^{2}$ Servicio de Enfermedades Infecciosas. Hospital Universitario Clínico San Cecilio. Granada.

Article history

Received: 10 May 2021; Revision Requested: 15 June 2021; Revision Received: 26 August 2021; Accepted: 2 September 2021; Published: 19 November 2021

\section{Sir,}

SARS-CoV-2 infection is commonly related to lung manifestations, the most severe of them being acute respiratory distress syndrome. This infection can sometimes affect many other organs (central nervous system, heart, bowel, etc.) but diarrhea and abdominal pain are the main symptoms from the digestive point of view [1]. Acalculous cholecystitis has been reported as an uncommon complication following severe COVID-19 pneumonia [2]. We report two cases of patients with SARS-CoV-2 infection without any respiratory compromise but being diagnosed of acalculous cholecystitis.

Patient 1 was a 87-year-old woman who came to the emergency department (ED) of our hospital complaining about fever and upper-abdominal pain. No other abdominal symptoms were reported and her respiratory exploration was completely normal. Examination revealed a positive Murphy's sign and her blood test indicated a high white blood cell count and an elevation of acute phase reactants. An abdominal ultrasound revealed gallbladder's wall thickening and a significant amount of perivesicular fluid; without gallstones. Prior to admission, following our hospital protocol, nasopharyngeal swab for RT-PCR for SARS-CoV-2 was performed and yielded a positive result. Endovenous piperacillin-tazobactam was given for 7 days, with good clinical evolution and it was decided not to operate.

Patient 2 was a 62 -year-old man who came to the ED because of fever $\left(39,1^{\circ} \mathrm{C}\right)$, nausea and pain located in his right-upper abdominal quadrant. He did not complain about any respiratory symptoms. C-reactive protein, procalcitonin and blood leukocyte count were marked elevated. Blood cultures were finally negative. An abdominal ultrasound was performed, which confirmed an acute cholecystitis and did not visualize any gall-

Correspondence:

Fernando Berdugo Hurtado

Hospital Universitario Clinico San Cecilio.

Av. Innovación s/n. CP 18014. Granada (Spain)

E-mail: fernando_bh94@hotmail.com stones. He also presented positive RT-PCR for SARS-CoV-2 prior to admission. Given the marked improvement and favorable evolution after starting antibiotic therapy with ceftriaxone, it was agreed to perform delayed cholecystectomy.

The two patients did not present any respiratory symptoms upon admission or during their hospital stay. Finally, they were discharged, once the absence of SARS-CoV-2 was confirmed by RT-PCR at 8 and 12 days after admission, respectively.

SARS-type coronaviruses mediate their intracellular entry through the receptor for angiotensin converting enzyme 2 (ACE-2), which is present in various tissues such as the lung, liver or the gallbladder [1-3]. TMPRSS2 co-receptor is also essential for viral entry, and it is widely found in gallbladder tissue $[4,5]$. Some publications have confirmed a relationship between SARS-CoV-2 and acalculous cholecystitis in patients with SARS $\mathrm{CoV}-2$, and some of them have confirmed the presence of the virus by performing RT-PCR in the gallbladder tissue. Ying et al. performed RT-PCR of the bile fluid after percutaneous cholecystostomy in a patient with acute cholecystitis without detecting SARS-CoV-2 [6]. In contrast, Balaphas et al. confirmed by RT-PCR the presence of the virus in the gallbladder wall of a patient with cholecystectomy after an episode of acalculous cholecystitis and COVID-19 infection [7].

All these findings confirm the presence of SARS-CoV-2 in the gallbladder tissue, and the pathogenic mechanism of viral entry mediated by specific viral receptor in the cholangiocytes. Some authors have proposed calling this process "novel coronavirus cholecystitis" [8]. In any case, there are still many gaps in the knowledge of this specific form of presentation of COVID-19.

From April 2020 to February 2021 another 8 patients with lithiasic cholecystitis were admitted to our hospital being RTPCR for SARS-CoV-2 positive at admission. Even when there is a causative relationship between the presence of gallstones and the development of cholecystitis, it is reasonable to think in SARS-CoV-2 as a trigger of the acute inflammatory process. 
The pathological study of the gallbladder would be of interest, but all our cases were treated without surgery.

We cannot establish the true causative role of SARS-CoV-2 in the pathogenesis of cholecystitis in our patients, and SARSCoV-2 infection could also be fortuity. Cholecystitis secondary to SARS-CoV-2 should be more frequent in moderate or severe COVID-19 but a mild disease could also trigger acute viral cholecystitis without severe pulmonary disease, as we hypothesize.

We finally suggest that cholecystitis could be the only manifestation of COVID-19, without associated respiratory symptoms. We propose that SARS-CoV-2 should be ruled out prior to admission by performing nasopharyngeal RT-PCR in every patient with cholecystitis with or without gallstones, in order to stop the spread and adopt specific measures for these patients.

\section{FUNDING}

None to declare

\section{CONFLICTS OF INTEREST}

The authors declare no conflicts of interest

\section{REFERENCES}

1. Gavriatopoulou M, Korompoki E, Fotiou D, Ntanasis-Stathopoulos I, Psaltopoulou T, Kastritis $E_{1}$ et al. Organ-specific manifestations of COVID-19 infection. Clin Exp Med. 2020;20(4):493-506. doi: 10.1007/s10238-020-00648-x

2. Puig G, Giménez-Milà $M$, Campistol $E_{1}$ Caño V, Valcarcel J, Colomina MJ. Development of concomitant diseases in COVID-19 critically ill patients. Rev Esp Anestesiol Reanim. 2021;68(1):37-40. doi: 10.1016/j.redar.2020.09.001.

3. Bruni A, Garofalo E, Zuccalà V, Currò G, Torti C, Navarra G, et al. Histopathological findings in a COVID-19 patient affected by ischemic gangrenous cholecystitis. World J Emerg Surg. 2020;15(1):1-8. doi: 10.1186/s13017-020-00320-5

4. Zhao B, Ni C, Gao R, Wang Y, Yang L, Wei J, et al. Recapitulation of SARS-CoV-2 infection and cholangiocyte damage with human liver ductal organoids. Protein Cell. 2020;11(10):771-5. doi: 10.1007/ s13238-020-00718-6

5. Marjot T, Webb GJ, Barritt AS, Moon AM, Stamataki Z, Wong VW, et al. COVID-19 and liver disease: mechanistic and clinical perspectives. Nat Rev Gastroenterol Hepatol. 2021;0123456789. doi:10.1038/s41575-021-00426-4

6. Ying $M, L u$ B, Pan J, Lu G, Zhou S, Wang D, et al. COVID-19 with acute cholecystitis: A case report. BMC Infect Dis. 2020;20(1):1-4. doi: 10.1186/s12879-020-05164-7

7. Balaphas A, Gkoufa K, Meyer J, Peloso A, Bornand A, McKee TA, et al. COVID-19 can mimic acute cholecystitis and is associated with the presence of viral RNA in the gallbladder wall. J Hepatol. 2020;73(6):1566-8. doi: 10.1016/j.jhep.2020.08.020.
8. Yu X. COVID-19 and Novel Coronavirus Cholecystitis. J Clin Gastroenterol. 2021;55(4):368. doi: 10.1097/MCG.0000000000001488 
María del Pilar Aguilar Jaldo David Vinuesa Garcia

\section{Síndrome de Froin secundario a absceso epidural}

Emilio Guirao Arrabal

Servicio de Medicina Interna. Área de Enfermedades Infecciosas. Hospital Universitario Clínico San Cecilio. Granada, España.

Article history

Received: 23 May 2021; Revision Requested: 3 August 2021; Revision Received: 12 September 2021; Accepted: 21 September 2021; Published: 22 November 2021

Estimado Editor: El sindrome de Froin fue descrito por Georges Froin en 1910. Consiste en la elevación de proteinas, hipercoagulabilidad y xantocromía en líquido cefalorraquídeo (LCR) como consecuencia de un bloqueo en la circulación del mismo, secundario a la presencia de una masa o absceso a nivel medular. La coexistencia de estos tres signos es patognomónica.

Presentamos el caso de un varón de 79 años, hipertenso y dislipémico, que tres semanas antes de acudir a urgencias, comenzó con dolor en región cervico-dorsal de tipo mecánico, debilidad de miembros inferiores de instauración progresiva y dificultad para la deambulación. No referia otra sintomatología en la anamnesis por órganos y aparatos.

A la exploración física sólo destacaba fiebre de $38,5^{\circ} \mathrm{C}$ sin clara focalidad y el resto era rigurosamente normal. La exploración neurológica mostró un balance muscular normal, la sensibilidad somática y cortical estaban conservadas, así como los reflejos osteotendinosos; no presentaba datos de meningismo, con los signos de Brudzinski y Kernig negativos.

Entre las pruebas complementarias realizadas, destacaba leucocitosis 19.830/mm3 con neutrofilia, elevación de reactantes de fase aguda (PCR 320mg/L y PCT 8,65 ng/mL) y un líquido cefalorraquideo con los siguientes resultados: 479 hematies/ $\mu \mathrm{L} ; 10$ leucocitos/ $/ \mu \mathrm{L}(60 \% \mathrm{M} ; 40 \%$ PMN); glucosa $52 \mathrm{mg} / \mathrm{dL}$ (plasmática 127); proteínas $773 \mathrm{mg} / \mathrm{dL}$. A la inspección visual de la muestra se observaba xantocromía y la tinción de Gram, PCR de virus y bacterias resultaron negativas. Se realizaron hemocultivos donde se aisló Staphylococcus aureus sensible a meticilina, por lo que se solicitó un ecocardiograma transesofágico que descartó la existencia de endocarditis y una resonancia magnética (RM) con contraste de columna donde se observaban varios abscesos (figura 1).

Correspondencia:

Maria del Pilar Aguilar Jaldo.

Servicio de Medicina Interna. Área de Enfermedades Infecciosas. Hospital Universitario Clinico

San Cecilio. Granada, España.

E-mail: pilaraguilarj@gmail.com

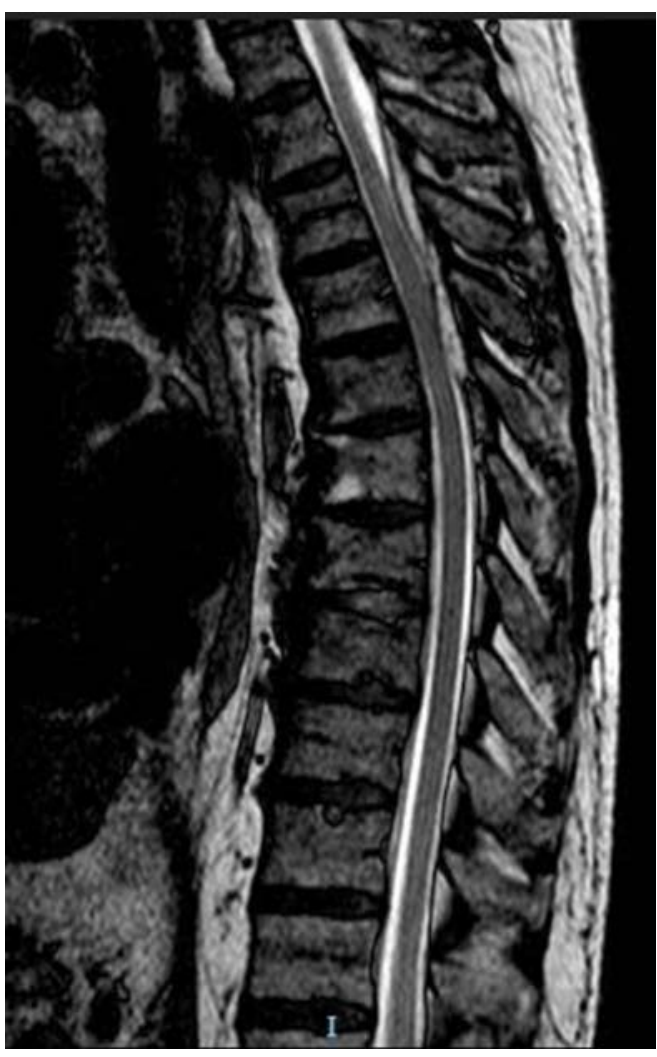

\begin{tabular}{l|l} 
Figura 1 & Resonancia magnética con contraste
\end{tabular} de columna cervical-dorsal-lumbar que demuestra absceso paravertebral posterior izquierdo de aprox. $36 \times 6 \mathrm{~mm}$ desde nivel de D3 hasta D4 y absceso epidural posterior de aprox. $74 \mathrm{~mm}$ de longitud y grosor máximo de aprox. 7 $\mathrm{mm}$ que se extendía desde cuerpo de D3 hasta D6, provocando compresión medular. 
El paciente inició tratamiento con cloxacilina intravenosa las dos primeras semanas y posteriormente dalbavancina como tratamiento de consolidación, con evolución clínica favorable, siendo dado de alta sin secuelas neurológicas. Tras haber completado 6 semanas de antibioterapia, se realizó RM de control en la que habian desaparecido los abscesos.

Los abscesos epidurales son poco frecuentes $(0,2-2,8$ casos/10.000 ingresos/año), con incidencia máxima entre 60-70 años. Afectan con mayor frecuencia a nivel posterior de la región toracolumbar. Entre los factores predisponentes se encuentran diversas situaciones que confieren inmunodepresión (diabetes mellitus, alcoholismo, etc), traumatismos o intervenciones de la columna vertebral, entre otras. Sin embargo, hasta un $20 \%$ de los casos, han sido descritos en pacientes sin factores predisponentes [2], como ocurría en nuestro caso.

El microorganismo causal más frecuente es $S$. aureus $(60 \%)$, seguido de los bacilos gramnegativos (16\%) y estrepto$\operatorname{cocos}(9 \%)$. Las manifestaciones clínicas son muy inespecificas. La triada clásica consistente en dolor de espalda (75\%), fiebre $(50 \%)$ y déficits neurológicos (33\%), solo está presente en el 10-15\% de los pacientes en el momento del diagnóstico, que suele realizarse mediante RM, hemocultivos (positivos en el $60 \%$ de los casos) y/o cultivo del absceso.

Aunque la intervención quirúrgica precoz se ha considerado durante un tiempo el principal pilar terapéutico, en la actualidad no existe consenso respecto al manejo de esta entidad en la que la tasa de mortalidad es de hasta el 14\% [3]. Actualmente, algunos autores recomiendan un manejo conservador con antibioterapia prolongada de forma aislada o bien combinada con drenaje percutáneo guiado por TC, evitando así la necesidad de intervención quirúrgica. Dicho manejo, ha demostrado ser efectivo independientemente de la edad, presencia de comorbilidades, duración de la enfermedad o tamaño del absceso [4]. La antibioterapia aislada podría estar indicada en pacientes con elevado riesgo quirúrgico o en aquellos sin pérdida funcional neurológica grave [5], como ocurría con nuestro paciente. Por su parte, la cirugía estaría justificada en caso de compresión espinal con efecto masa, inestabilidad espinal y deformidad, o la imposibilidad de obtener un aislamiento microbiológico [6].

En cuanto al uso de dalbavancina como tratamiento de consolidación frente a microorganismos grampositivos, una vez alcanzada la estabilidad clínica del paciente, se postula como una estrategia eficaz y coste-efectiva [7]. Esto ocurre especialmente en terapias de duración prolongada, tanto en infección osteoarticular, como en endocarditis y bacteriemia asociada a catéter, permitiendo además reducir la estancia hospitalaria de los pacientes $[7,8]$.

El sindrome de Froin es un proceso fisiopatológico complejo que requiere un alto índice de sospecha y vigilancia estrecha durante las primeras etapas de evolución clínica. Como recomiendan Govindarajan R et al [9], ante una elevación marcada de proteinas en LCR, generalmente superiores a 500 $\mathrm{mg} / \mathrm{dL}$, con escasa celularidad y la presencia de xantocromía, habría que sospechar obstrucción del flujo del LCR y se debería solicitar una RM para realizar un diagnóstico y un tratamiento precoz, para reducir así la morbimortalidad de estos pacientes.

\section{FINANCIACIÓN}

Los autores declaran no haber recibido financiación para la realización de este estudio.

\section{CONFLICTO DE INTERESES}

Los autores declaran no tener ningún conflicto de intereses.

\section{BIBLIOGRAFÍA}

1. Dancel $R$, Shaban M. Images in clinical medicine. Froin's syndrome. N Engl J Med, 2016;374(11):1076. doi: 10.1056/NEJMicm 1509557.

2. Vilke $G M$, Honingford EA. Cervical spine epidural abscess in a patient with no predisposing risk factors. Ann Emerg Med 1996;27(6):77780. doi: 10.1016/s0196-0644(96)70201-9.

3. Maslen DR, Jones SR, Crisplin MA, et al. Spinal epidural abscess: optimizing patient care. Arch Intern Med 1993;153:1713-21. PMID: 8333809.

4. Siddiq F, Chowfin A, Tight $R$, et al. Medical vs Surgical Management of Spinal Epidural Abscess. Arch Intern Med 2004;164(22):2409-12. doi: 10.1001/archinte.164.22.2409.

5. Leys $D_{\text {, Lesoin }}$, Viaud $C_{\text {, et }}$ al. Decreased morbidity from acute bacterial spinal epidural abscesses using computed tomography and nonsurgical treatment in selected patients. Ann Neurol 1985;17(4):350-5. doi: 10.1002/ana.410170408.

6. Del Curling Jr O, Gower DJ, McWhorter JM. Changing concepts in spinal epidural abscess: a report of 29 cases. Neurosurgery 1990;27(2):185-92. doi: 10.1097/00006123-199008000-00002.

7. Hidalgo-Tenorio C, Vinuesa D, Plata A, et al. DALBACEN cohort: dalbavancin as consolidation therapy in patients with endocarditis and/or bloodstream infection produced by gram-positive cocci. Ann Clin Microbiol Antimicrob 2019;18(1):30. doi: 10.1186/ s12941-019-0329-6.

8. Veve MP, Patel N, Smith ZA, et al. Comparison of dalbavancin to standard-of-care for outpatient treatment of invasive Gram-positive infections. Int J Antimicrob Agents. 2020;56(6):106210. doi: 10.1016/j.jjantimicag.2020.

9. Govindarajan R, Khan T. Froin's syndrome: an uncommon mimicker of Guillain-Barre syndrome. Eur Spine J 2012;21(8):1674-5. doi: 10.1007/s00586-012-2277-0. 
Didem Çelik

İlker Ödemiș²

Metin Korkmaz

Şükran Köse ${ }^{4}$

\section{A rare case of cardiac alveolar echinococcosis without any complications for eight years}

\author{
${ }^{1}$ Bakırçay University, Çiğli Education and Research Hospital, Department of Infectious Diseases and Clinical \\ Microbiology, Izmir, Turkey \\ ${ }^{2}$ Baskent University Adana Dr. Turgut Noyan Application and Research Center, Department of Infectious Diseases and \\ Clinical Microbiology, Adana, Turkey \\ ${ }^{3}$ Ege University, Department of Parasitology, Izmir, Turkey \\ ${ }^{4}$ University of Health Sciences, Izmir Tepecik Education and Research Hospital, Department of Infectious Diseases and \\ Clinical Microbiology, Izmir, Turkey
}

\section{Article history}

Received: 22 May 2021; Revision Requested: 16 June 2021; Revision Received: 8 August 2021; Accepted: 30 September 2021; Published: 26 November 2021

\section{Sir,}

Human alveolar echinococcosis (AE) is caused by the metacestode of Echinococcus multilocularis (EM) and it is considered to be the most potentially lethal parasitic zoonosis in the nontropical areas of the Northern Hemisphere [1]. AE is a rare parasitic disease and sporadic in Turkey. It can be encountered in dogs, cats, foxes, and domestic pigs which is transmitted via the fecal-oral route from contaminated foods and water or via close contact with infected animals. This disease is characterized by an infiltrative, tumor-like growth of the EM metacestode commonly in the liver of humans, followed by the lung, kidney, bone, and brain [2]. Cardiac involvement constitutes 0.5 to $2 \%$ of total cases and Cardiovascular surgery should be planned first [3]. The present study aims to discuss diagnosis, etiology, and treatment from a case with EM infection spread over the heart, lungs, and soft tissues.

A 26-year-old male patient with no history of chronic diseases presented to the outpatient clinic with swelling, enlargement, and pain in the left femoral region and difficulty in walking. Systemic inquiry of the patient revealed no additional complaints; personal history revealed smoking of 5 pack/year; the family history was unremarkable. On his physical examination, an increase was determined in the diameter of the proximal aspect of the left leg with a $3 \times 2 \mathrm{~cm}$ painful mass palpated on the lateral aspect of the left femoral region. Additional systemic examination was normal, vital signs were as following; body temperature: $36.5{ }^{\circ} \mathrm{C}$, pulse rate:78/min, blood pressure:110-70 mm/Hg. The patient, who had no history of trauma, underwent magnetic resonance imaging of the femur and pelvis. Regarding to the laboratory analyses, no abnormality was determined through full blood count, blood biochemistry, or autoimmune parameters. Radiological examination of the

\section{Correspondence:}

Didem Çelik

Department of Infectious Diseases and Clinical Microbiology, Bakırçay University, Çiğli Education and Research Hospital, Yeni Mahalle, 8780/1. St. No:18, Çiğli, İzmir, 35620, Turkey Tel: +905543578646

E-mail: didemdestioglu@gmail.com patient demonstrated multiple space-occupying cystic lesions, the largest of them was $2 \times 5 \mathrm{~cm}$, in the left gluteus maximus, adductor, vastus lateralis and vastus medialis muscles of the quadriceps femoris group (Figure 1a-1b). Depending on the radiological examination EM infection was considered. When the patient's anamnesis was questioned again in terms of EM, it was learned that he was living with his dog and has a history of eating steak tartar a la turca, unwashed raw vegetables and fruits. The indirect hemagglutination test (IHA) test result for hydatid cyst was 1/1280 and the western blotting was positive (Figure 2). The brain and liver appeared to be normal on the whole-body magnetic resonance imaging, which was performed for screening purposes. A $27 \times 25 \mathrm{~mm}$ lesion with a slight thickness of hyperdense wall was detected in the posterior aspect of the cardiac interventricular septum (Figure 3) and multiple cystic lesions; the largest of which was $22 \times 17$ $\mathrm{mm}$, were detected in the bilateral lung parenchyma (Figure 4). Heterogeneous, hypodense lesions, which are $2 \mathrm{~cm}$ in diameter and attached to the surrounding tissues, were detected in the anterior and postero-lateral aspects of the left psoas muscle. PNM system for classification of human alveolar echinococcosis was PXN1M1 (Stage IV), therefore the cyst in the cardiac interventricular septum was consulted to the Department of Cardiology and Cardiovascular Surgery, however medical therapy was preferred as the patient did not consent for cardiac surgery as the surgery might be life-threatening. Albendazole was ordered at a dose of $2 \times 400 \mathrm{mg}$. The cyst compressing vena iliaca in the retroperitoneum was resected. In pathological examination of this cyst; a fibrous wall, $9 \times 5 \times 2.5 \mathrm{~cm}$ in size, containing adipose tissue areas on its outer surface, and a large number of cuticular membranes with the largest diameter of $4.5 \mathrm{~cm}$ and the smallest millimetric were observed. The cardiac magnetic resonance imaging performed after 3 months of medical therapy revealed regression in the size of the intracardiac cyst. On the 6th month and 1st-year control visits, no progression was determined in the size of cysts with no additional complaint. Furthermore no side effects were observed. 

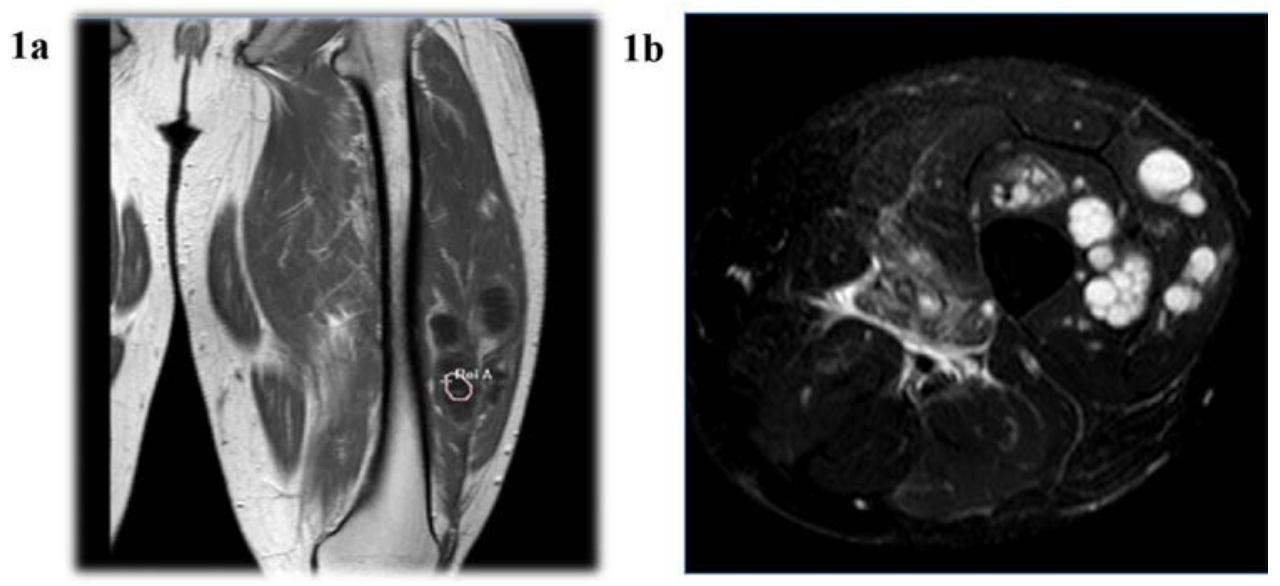

Figures 1 1a-1b. Multiple space-occupying cystic lesions, the largest of which was $2 \times 5 \mathrm{~cm}$, in the left muscles of the quadriceps femoris group

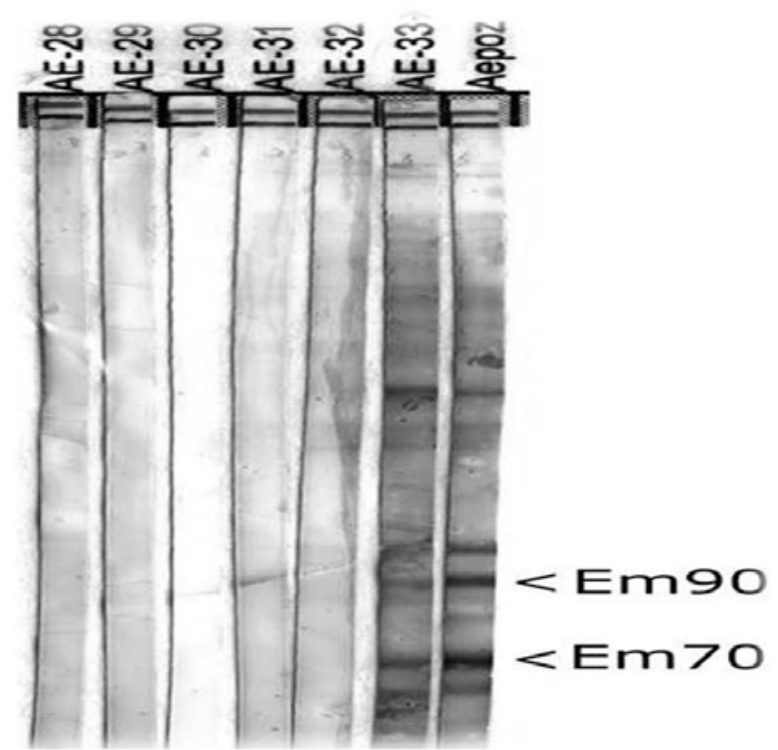

\begin{tabular}{c|l}
\hline Figure 2 & $\begin{array}{l}\text { The presence of both } 70-\text { and } 90-\mathrm{kDa} \\
\text { bands (Em70 and Em90, respectively) } \\
\text { was interpreted as a positive result for }\end{array}$ \\
& $\begin{array}{c}\text { Alveolar echinococcosis (AE). Aepoz; } \\
\text { positive control, AE-33; presented case, } \\
\text { AE-28-32 negative cases for AE }\end{array}$
\end{tabular}

After completing the first year, despite all risks the patient discontinued albendazole treatment voluntarily and continued to be followed up at close intervals. The patient has been followed up for eight years until now, he is still alive without any complications. During the follow-up period, whole-body imaging was repeated, the patient had no new cardiac complaints and no change was observed in the lesions.
$\mathrm{EM}$ is a zoonotic infection with multisystem involvement and a mortality rate of $4 \%$. AE is endemic especially in eastern Turkey. Of the AE cases, $87.4 \%$ reported in our country are from East and Southeast Anatolia [4]. The incubation period ranges from 5 to 15 years, the diagnosis usually delays because of the long incubation period $[5,6]$. In general, it involves primarily in the liver and then reaches to the pancreas, spleen, lungs, retroperitoneum, heart, brain, bone, and soft tissues via the extrahepatic spread. Lungs and brain involvement accounts for $20 \%$ of the spreads. The interesting point of our case was that the patient had a cyst in his heart despite no cysts in his liver, this reflects a very rare situation.

The diagnosis is made based on geographical prevalence, anamnesis, clinical findings, serological tests, and radiological findings. But in some cases, the diagnosis can be more difficult because the disease can present with various symptoms. The area where the patient lives, the foods he eats, and his occupation should be questioned. Computerized tomography and magnetic resonance imaging are helpful in diagnosis. Serology is more sensitive and specific than imaging [7]. IHA, Enzym Linked Immunosorbent Assay, and Indirect Fluorescent Antibody Test are the most useful and most commonly used serologic tests for diagnosis of $A E[7,8]$. In this case; the serologic diagnosis was done by IHA and western blot. The diagnostic specificity is $94.1 \%$, and the sensitivity is $100 \%$ in cases where IHA and WB tests are performed together [9]. Although in some cases, immune deficits may predispose to parasitic infections, in this case immune analyzes could not be performed because human leukocyte antigen typing and interleukin levels analysis were not available in our hospital. However, immunodeficiency was not considered in the patient who did not have a history of frequent infections and did not have anergic purified protein derivative (PPD) test.

In the differential diagnosis, metastatic tumors, bacterial metastatic abscesses, other parasitic infections, tuberculo- 


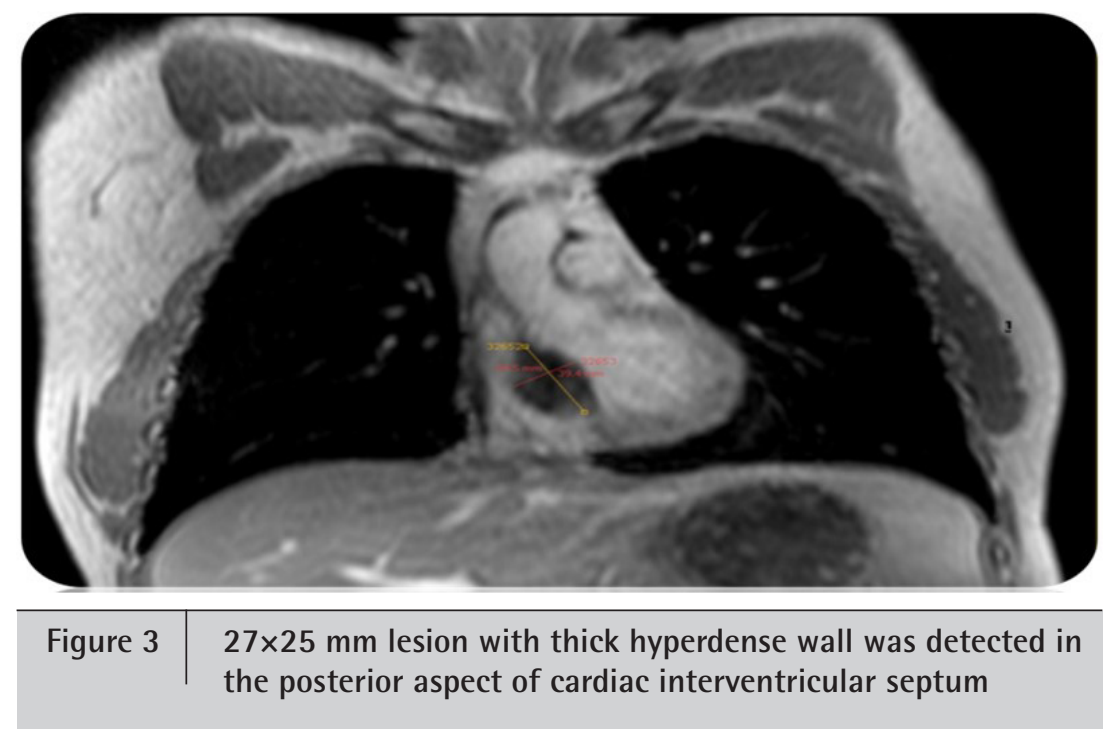

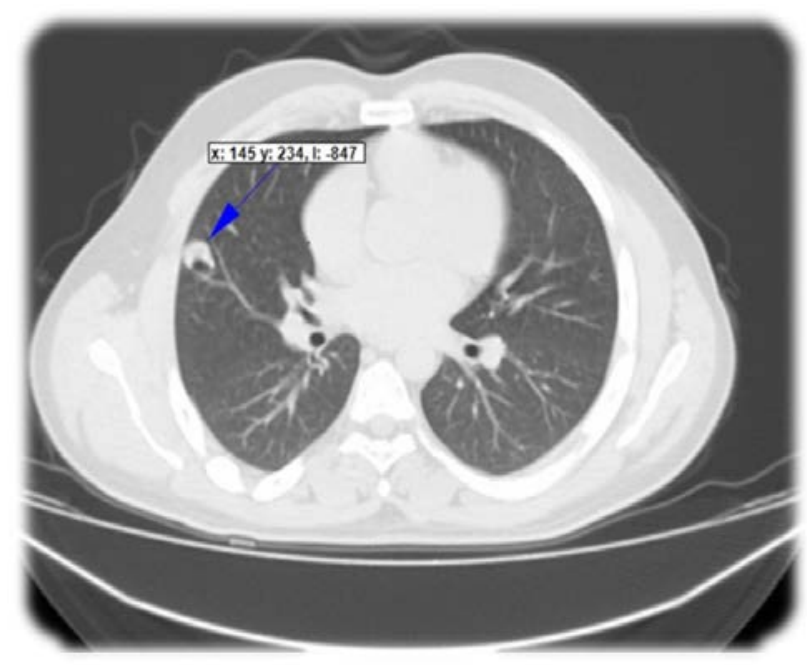

Figure $4 \quad$ Multiple cystic lesions in the bilateral lung parenchyma

sis should be considered. AE may mimic the tumor of the site where it is located especially if it's located in the liver. It can make distant organ metastasis by blood vessel invasion like tumors. Cardiac involvement constitutes 0.5 to $2 \%$ of the total cases. Surgery is the preferred treatment. Venous filters may be used to prevent the spread of the disease. When complete removal of cysts is possible, both the recurrence rate is low and the prognosis is good [3]. In our case, the patient did not give consent to cardiac surgery, so we decided to follow the patient by close intervals and preferred medical treatment.

Albendazole, a benzimidazole derivative, is indicated for inoperable patients with two or more organs or more than one cyst in the peritoneal region [3]. Lifelong treatment is often necessary to inhibit the development of parasites in patients who cannot benefit from radical surgery [6]. As a side effect, liver dysfunction, alopecia, neutropenia, and leukopenia can be seen $[4,6]$. We didn't detect any drug side effects in our patient. When the patients don't receive medical treatment, $70 \%$ of patients die within 5 years, and $90 \%$ within 10 years [2]. Chemotherapy should be continued for at least 2 years after surgery and patients should be monitored for at least 10 years [2]. When surgery is not appropriate, albendazole should be continued to prevent the progression of infection [10]. Although the general approach for treatment is surgery or lifelong medical treatment, in our case, long-term survival with one-year medical treatment can be a good guide for the success of medical treatment.

In conclusion, the patients diagnosed with AE should undergo whole-body screening including the lungs, heart, brain, pancreas, spleen bone, and soft tissue as early as possible. Surgical resection is the curative option for the treatment of disease; however, medical therapy is also an option where surgery is risky. The treatment should be planned with a multidisciplinary team that should include at least one infectious disease physician, radiologist, hepatology specialist, surgeon, with experience [6].

\section{ACKNOWLEGDEMENTS}

This study was presented as a poster presentation at International Symposium on Parasitic Zoonoses TMC Parasitology Working Group 16-20 November 2016 Titanic Deluxe Hotel Belek- Antalya.

\section{FUNDING}

None to declare 


\section{CONFLICTS OF INTEREST}

The authors declare no conflicts of interest.

\section{REFERENCES}

1. Korkmaz M, Inceboz T, Celebi F, Babaoglu A, Uner A. Use of two sensitive and specific immunoblot markers, Em70 and Em90, for diagnosis of alveolar echinococcosis. J Clin Microbiol. 2004;42(7):33502. doi: 10.1128/JCM.42.7.3350-3352.2004.

2. Pohnan R, Ryska M, Hytych V, Matej R, Hrabal P, Pudil J. Echinococcosis mimicking liver malignancy: A case report. Int I Surg Case Rep. 2017;36:55-8. doi: 10.1016/j.jijscr.2017.04.032

3. Brunetti E, Kern P, Vuitton DA. Expert consensus for the diagnosis and treatment of cystic and alveolar echinococcosis in humans. Acta trop. 2010;114(1):1-16. doi: 10.1016/j.actatropica.2009.11.001

4. Aras Y, Sabancı PA, Boyalı 0 , Aydoseli $A$, Güllüoğlu $M$, Bilgiç $M B$, et al. Kraniyal Metastazlı Alveolar Ekinokok: Olgu Sunumu ve Literatürün Gözden Geçirilmesi. Türk Nöroşir Derg. 2014;24(3):298-305.

5. Spahn S, Helmchen B, Zingg U. Alveolar echinococcosis of the right adrenal gland: a case report and review of the literature. J Med Case Rep. 2016;10(1):325. doi: 10.1186/s13256-016-1115-0

6. Nail LC, Reimundes ER, Galluzzo CW, Lebowitz D, Ibrahim YL, Lobrinus $J A$, et al. Disseminated alveolar echinococcosis resembling metastatic malignancy: a case report. J Med Case Rep. 2017;11(1):113. doi: 10.1186/s13256-017-1279-2

7. Aydın Y, Altuntaş $B$, Eroğlu A, Oğul H, Aydınlı B. Treatment approach for pulmonary alveolar echinococcosis. Turk J Thorac Cardiovasc Surg. 2017;25(2):223-9. doi: 10.5606/tgkdc.dergisi.2017.12486

8. Dülger AC, Küçükoğlu ME, Akdeniz H, Avcu S, Kemik Ö. Case report: Budd-Chiari syndrome and esophageal variceal bleeding due to alveolar echinococcosis. Turkiye Parazitol Derg. 2010;34(3):187-90. PMID: 20954122

9. Yılmaz GR, Babür C. Ekinokokkosis Tanısı. Turk Hij Den Biyol Derg. 2007:64(3):35-44.

10. Torgerson PR, Schweiger A, Deplazes P, Pohar M, Reichen J, Ammann RW, et al. Alveolar echinococcosis: from a deadly disease to a well-controlled infection. Relative survival and economic analysis in Switzerland over the last 35 years. J Hepatol. 2008;49(1):72-7. doi:10.1016/j.jhep.2008.03.023 
Lucia Chaves Blanco

Cristina Gómez-Camarasa

Marta Illescas López

Natalia Chueca Porcuna

Laura L. Rojas-García

\section{Unusual isolation of Pseudoglutamicibacter cumminsii in urine culture}

Microbiology Clinic Unit, Hospital Universitario San Cecilio. Granada, Spain.

Article history

Received: 12 June 2021; Revision Requested: 21 August 2021; Revision Received: 31 August 2021; Accepted: 2 September 2021; Published: 29 November 2021

\section{Sir,}

Pseudoglutamicibacter cumminsii is an aerobic, catalase-positive, Gram-positive coccobacillus commonly found in soil. Recently, a change has been made in the taxonomy of this species, which was previously classified as Arthrobacter cumminsii [1]. The literature associated with urinary tract infection (UTI) is rare [2,3], although other cases of infections caused by related species within this genus, such as bacteraemia caused by A. creatinolyticus [4] or endocarditis caused by A. woluwensis [5], have been reported.

A 34-year-old woman with no personal history of interest visited her primary care medical centre with persistent urinary symptoms. She was diagnosed with cystitis and was prescribed Fosfomycin $3 \mathrm{~g}$ oral solution, two doses. Two weeks later, she returned to the health centre reporting continued urinary symptoms, without episodes of fever.

The patient was asked to send a urine sample for culture in the microbiology laboratory. The sample was inoculated in CPSO chromogenic medium (Biomerieux ${ }^{\circledR}$, Marcy L'Etoile, France) and incubated for 24 hours in a $37^{\circ}$ atmosphere. After the incubation time, a pure culture count of $>100,000 \mathrm{CFU} / \mathrm{ml}$ of a yellowish colony was observed (Figure 1).

Identification of the microorganism was performed by mass spectrometry, MALDI-TOF (Bruker ${ }^{\circledR}$, Bremen, Germany). Pseudoglutamicibacter cumminsii was obtained with a score of 1.65. The identification was confirmed by using $16 \mathrm{~S}$ rRNA gene sequence (GenBank accession number: MZ293797). Antibiotic susceptibility was tested by disc diffusion and Corynebacterium cut-off points in EUCAST (European Committee on Antimicrobial Susceptibility Testing) 2021 were taken as a reference for antibiogram interpretation. The susceptibility profile reported was as follows: susceptible to imipenem,

Correspondencia:

Cristina Gómez Camarasa

Microbiology Clinic Unit, Hospital Universitario San Cecilio. Granada, Spain.

E-mail: gomezcamarasa@gmail.com

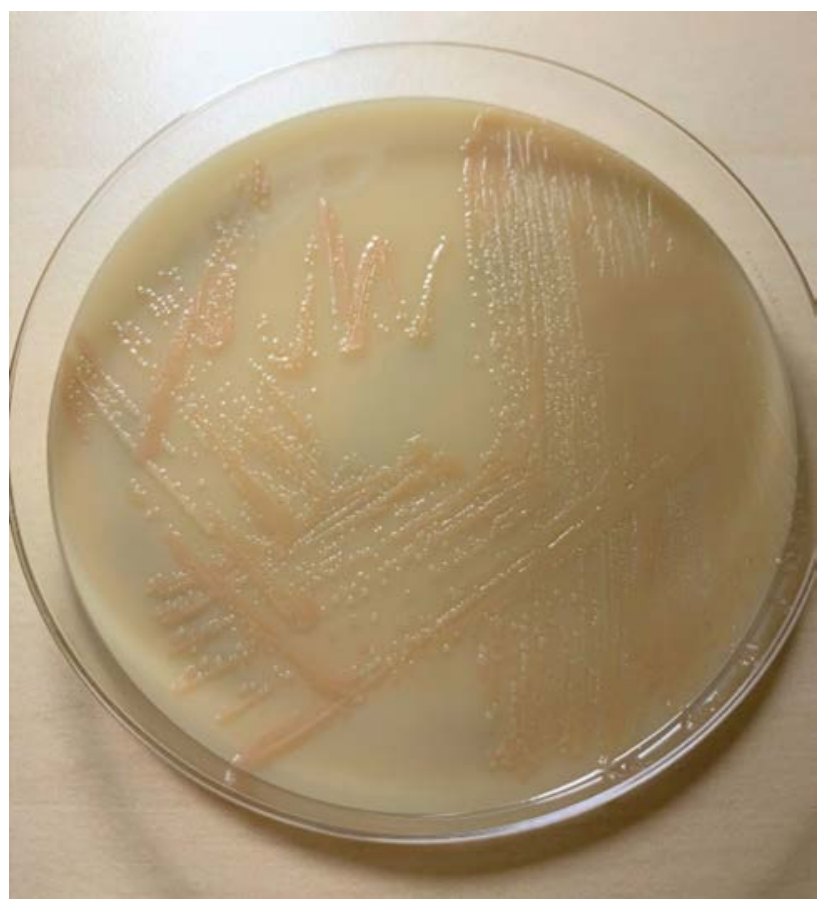

Figure $1 \quad$ Colonies of $P$. cumminsii grown in $\mathrm{CPSO}^{\circledR}$ chromogenic agar (Biomerieux ${ }^{\circledR}$ )

linezolid, rifampicin, tetracycline and vancomycin, and resistant to ciprofloxacin, clindamycin, erythromycin, gentamicin, levofloxacin and penicillin.

Subsequently, the patient was treated with doxycycline $100 \mathrm{mg}$ for 7 days with successful results. No new post-treatment control sample was sent.

Few reports have associated this microorganism to urinary tract infection $[2,3]$. However, the etiology of UTI's can be very wide ranging, from the most common pathogens such as Es- 
cherichia coli, Proteus mirabilis or Klebsiella pneumoniae, to other less frequent pathogens described in the literature [6]. Accurate identification methods and antibiotic susceptibility constitute a fundamental tool in the diagnosis of urinary tract infections caused by underdiagnosed emerging pathogens.

\section{FUNDING}

None to declare

\section{CONFLICTS OF INTEREST}

The authors declare no conflicts of interest.

\section{REFERENCES}

1. Busse H-J. Review of the taxonomy of the genus Arthrobacter, emendation of the genus Arthrobacter sensu lato, proposal to reclassify selected species of the genus Arthrobacter in the novel genera Glutamicibacter gen. nov., Paeniglutamicibacter gen. nov., Pseudoglutamicibacter gen. nov., Paenarthrobacter gen. nov. and Pseudarthrobacter gen. nov., and emended description of Arthrobacter roseus. Int. J. Syst. Evol. Microbiol 2016;66:9-37. doi: 10.1099/ijsem.0.000702.

2. Navarro D, Aguilera A, Manso T, Vallejo A, Garcia X, Trastoy R, et al. Infección urinaria por Artrhrobacter cumminsii. Complejo Hospitalario Universitario de Santiago de Compostela. Póster presentado en: XX Congreso de la Sociedad Española de Enfermedades Infecciosas y Microbiología Clínica (SEIMC), 26-28 de mayo de 2016, Barcelona.

3. Pearce MM, Hilt EE, Rosenfeld AB, Zilliox MJ, Thomas-White $K$, Fok $C$, et al. The Female Urinary Microbiome: a Comparison of Women with and without Urgency Urinary Incontinence. MBio 2014;5:e01283-14. doi: 10.1128/mBio.01283-14.

4. Yamamoto K, Hayakawa K, Nagamatsu M, Fujiya Y, Mawatari M,

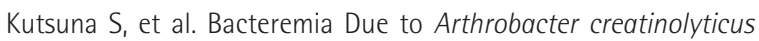
in an Elderly Diabetic Man with Acute Cholangitis. Jpn J Infect Dis 2017;70:201-2. doi: 10.7883/yoken.JJID.2016.033.

5. Durand C, Kouchit Y, Prots L, Degand N, Dellamonica P, Demonchy $E_{1}$ et al. A case of infective endocarditis caused by Arthrobacter woluwensis. Eur J Clin Microbiol Infect Dis 2021. doi: 10.7883/ yoken.JJID.2016.033.

6. Gómez-Camarasa C, Liébana-Martos C, Navarro-Marí JM, Gutiérrez-Fernández J. Detección de uropatógenos inusuales durante un periodo de 3 años en un hospital regional. Rev Esp Quimioter 2015; 28 (2): 86-91. PMID: 25904515. 
Edwin U. Suárez

Silvia Calpena²

\title{
Un paciente con mal de Pott
}

Beatriz Álvarez ${ }^{3}$

Miguel Górgolas ${ }^{3}$

Raúl Córdoba ${ }^{1}$

\begin{abstract}
'Departamento de Hematología, Hospital Universitario Fundación Jiménez Díaz, Madrid.
${ }^{2}$ Departamento de Medicina Interna, Hospital Universitario Fundación Jiménez Díaz, Madrid.

${ }^{3}$ División de Enfermedades Infecciosas, Hospital Universitario Fundación Jiménez Díaz, Madrid.
\end{abstract}

Article history

Received: 6 July 2021; Revision Requested: 26 July 2021; Revision Received: 27 July 2021; Accepted: 31 August 2021; Published: 23 November 2021

\section{Estimado Editor:}

Mujer de 58 años, con historia de dispepsia y tabaquismo, consultó por 6 meses de dorsalgia mecánica, progresiva, con pérdida significativa de peso, escalofríos e hiporexia. Una resonancia magnética evidenció espondilodiscitis T9-T10 con fractura del cuerpo vertebral, colección prevertebral y epidural sin mielopatía compresiva. La tomografía de tórax demostró un nódulo pulmonar ( $5 \mathrm{~mm}$ ), sin captación patológica en la tomografía con emisión de positrones ( $\left.{ }^{18} \mathrm{~F}-\mathrm{FDG} \mathrm{PET} / \mathrm{CT}\right)$ pero con compromiso espinal y adenopatías generalizadas con centro necrótico (Figura 1).

Mediante ecobroncoscopia (EBUS) la punción del ganglio paratraqueal evidenció fragmentos necróticos y citología negativa para malignidad; el cultivo, con crecimiento de Streptococcus constellatus y una prueba molecular (PCR) negativa para Mycobacterium tuberculosis (también en el lavado broncoalveolar). Se desestimó endocarditis infecciosa. La muestra de la punción percutánea espinal presentó positividad para M. tuberculosis por PCR. La biopsia gástrica demostró Helicobacter pylori y linfoma del tejido linfoide asociado a mucosa (MALT).

La incidencia de tuberculosis extrapulmonar se estima en el 20\% [1]; la afectación esquelética ocurre en el 10-35\%, siendo la espinal más frecuente (principalmente en la unión toraco-lumbar). Afecta inicialmente vértebras adyacentes antes de entrar al espacio discal, con riesgo de mielopatía compresiva [2]. En áreas no endémicas la tuberculosis esquelética generalmente es secundaria a reactivación [3]. El sintoma predominante es el dolor mecánico local progresivo de semanas a meses. La fiebre y pérdida de peso están en menos del 40\% de los casos [2]. El diagnóstico es un reto, pues no suele presentarse con sintomas respiratorios y el compromiso óseo es indolente, conllevando un retraso terapéutico. Aunque el ${ }^{18} \mathrm{~F}-$ FDG PET/CT es poco específico en el diagnóstico de infecciones, tiene alta tasa de detección (98\%), incluso al compararse con la sospecha clínica, pues identifica mejor la extensión y el número de órganos afectados [4]. El tratamiento médico oscila entre 9 y 12 meses. No se ha demostrado beneficio del tratamiento quirúrgico adyuvante; este debería considerarse si no hay respuesta a los antituberculosos, ante déficit neurológico o inestabilidad vertebral $[2,5]$.

S. constellatus, es un comensal de la cavidad oral y tracto genitourinario. Ante factores de riesgo, induce infecciones, incluso de alta patogenicidad, generalmente, de cabeza y cuello, del sistema nervioso central, intrabdominales, torácicas y bacteriemias, tendiendo a formar abscesos[6]. La espondilodiscitis es infrecuente, aunque existen casos reportados, incluyendo pacientes inmunocompetentes [7]. Las coinfecciones con bacilos gram negativos gastrointestinales y anaerobios son usuales [8], no siendo así con Mycobacterium tuberculosis. En nuestro caso, la manipulación de la vía aérea superior (EBUS) y la localización, apoya la teoría de contaminación.

El linfoma MALT, es inusual, de curso indolente, localizado preferentemente en tejido gástrico, anexos oculares y pulmón, aunque pudiera comprometer cualquier tejido. Relacionado a la estimulación inmune crónica por autoinmunidad o infecciones, clásicamente, $H$. pylori; otras incluyen: hepatitis $C$, Chlamydia psitacci, Campylobacter jejuni, Borrelia burdorgferi, Achromobacter xylosoxidans [9]. La asociación de S. constellatus o M. tuberculosis con linfoma MALT, no está concebida como causa-efecto. M. tuberculosis pudiera conducir a linfomatogénesis, o coexistir con algunas neoplasias [10]. Asimismo, el riesgo de tuberculosis e infecciones piógenas secundarias no difiere de la población general, salvo en los casos de progresión. Usualmente se manifiesta como enfermedad localizada, con sintomas gastrointestinales, pérdida de peso o sangrado oculto. Los "síntomas B" son infrecuentes (menos del 5\%), puede progresar a otros tejidos y en raras ocasiones a un linfoma $\mathrm{B}$ difuso de células grandes o amiloidosis [11]. El rol del ${ }^{18} \mathrm{~F}-$ 

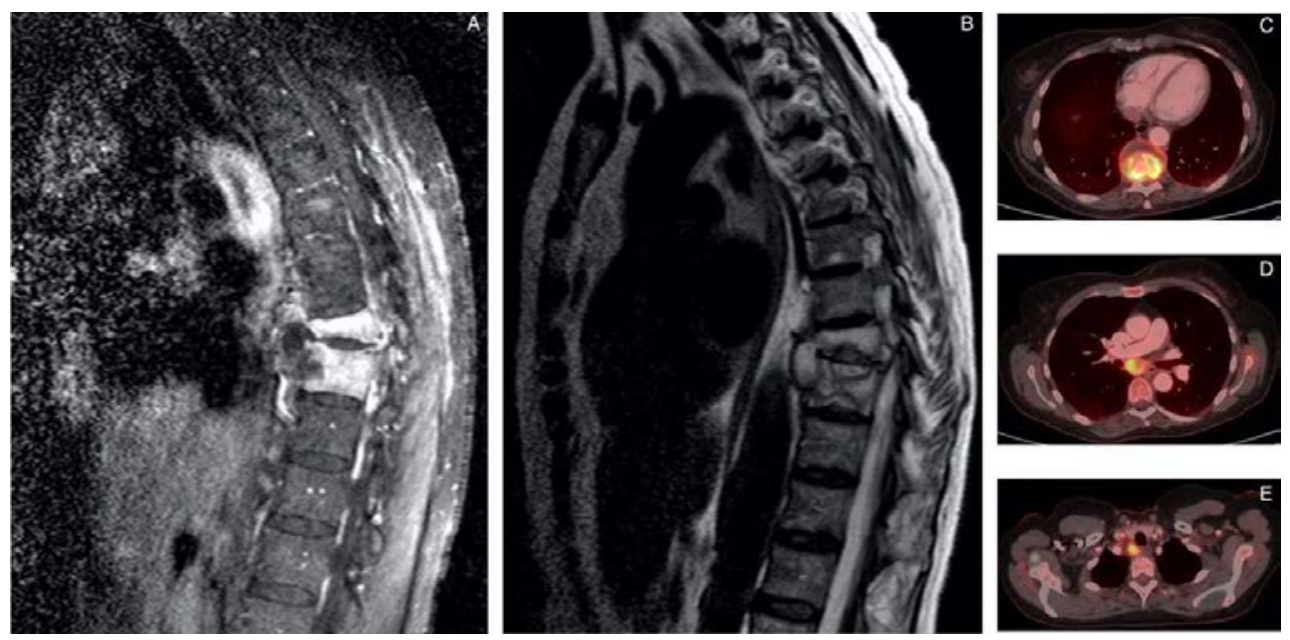

Figura 1

Resonancia magnética (RM) y ${ }^{18} \mathrm{~F}-\mathrm{FDG} \mathrm{PET} / \mathrm{CT}$. Imágenes sagitales de RM en T1-SPIR (A) y T2-TSE (B) con señal patológica en el disco intervertebral y cuerpos vertebrales T9-T10 con destrucción ósea y colecciones en tejidos blandos adyacentes. Imágenes de ${ }^{18} \mathrm{~F}-\mathrm{FDG}$ PET/CT (C, D, E) con captación patológica en T9-T10, ganglios paratraqueal y supraclavicular derechos (no se muestra el compromiso ganglionar a nivel de hilio hepático, precarinal y subcarinal).

FDG PET/CT en la estadificación del linfoma MALT es debatido, pues su avidez por la fluorodesoxiglucosa es variable. La histología demuestra células pequeñas con folículos reactivos en la zona marginal y/o la región interfolicular. El inmunofenotipo corresponde a linfocitos B positivos para CD19, CD20, y CD22 y negativos para CD5, CD10 y CD23, frecuentemente asociados a anormalidades cromosómicas (trisomía 3 o t(11;18)) $[9,11]$. El tratamiento inicial depende del estadio, localización, y la presencia de $H$. pylori, pues su erradicación generalmente obtiene la regresión del linfoma. Este linfoma incrementa el riesgo de adenocarcinoma gástrico y de otros linfomas, por tanto, requiere seguimiento [11]. En nuestro caso, la clasificación corresponde a T1m No M0 (Paris staging system), I (Lugano staging system), y tiene indicado seguimiento para evaluar erradicación.

Resaltamos entonces la importancia del estudio detallado del dolor dorsal y/o lumbar ante signos de alarma, considerando a $M$. tuberculosis como etiología, aún cuando no se provenga de regiones endémicas o exista compromiso pulmonar, sobretodo, cuando el curso sea insidioso y existan factores de riesgo. El diagnóstico diferencial del síndrome constitucional debe incluir etiologias infecciosas y neoplásicas, sin descartar su posible coexistencia, siendo primordial una adecuada correlación clínica, radiológica y microbiológica.

\section{FINANCIACIÓN}

Los autores declaran que no han recibido financiación para la realización de este trabajo.

\section{CONFLICTO DE INTERÉS}

Los autores declaran no tener ningún conflicto de intereses.

\section{BIBLIOGRAFÍA}

1. World Health Organization. Global tuberculosis report 2019. https://www.who.int/tb/publications/global_report/en/

2. Rajasekaran S, Soundararajan DCR, Shetty AP, Kanna RM. Spinal Tuberculosis: Current Concepts. Global Spine J. 2018;8(4 Suppl):96S-108S. doi: 10.1177/2192568218769053.

3. Kaufmann SH, Cole ST, Mizrahi V, Rubin E, Nathan C. Mycobacterium tuberculosis and the host response. J Exp Med. 2005;201(11):1693-7. doi: 10.1084/jem.20050842.

4. Sánchez-Montalvá A, Barios M, Salvador F, Villar A, Tórtola T, Molina-Morant D, Lorenzo-Bosquet C, Espinosa-Pereiro J, Molina I. Usefulness of FDG PET/CT in the management of tuberculosis. PLoS One. 2019;14(8):e0221516. doi: 10.1371/journal.pone.0221516.

5. Nahid P, Dorman SE, Alipanah N, Barry PM, Brozek JL, Cattamanchi A, et al. Official American Thoracic Society/Centers for Disease Control and Prevention/Infectious Diseases Society of America Clinical Practice Guidelines: Treatment of Drug-Susceptible TubercuIosis. Clin Infect Dis. 2016;63(7):e147-e195. PMID: 27516382

6. Jiang S, Li M, Fu T, Shan F, Jiang L, Shao Z. Clinical Characteristics of Infections Caused by Streptococcus Anginosus Group. Sci Rep. 2020;10(1):9032. doi: 10.1038/s41598-020-65977-z

7. Potsios C, Xaplanteri P, Zoitopoulos V, Patrinos P, Giannakopoulou 
II, Tzivaki I, et al. Pyogenic Spondylodiscitis due to Streptococcus constellatus in an Immunocompromised Male Patient: A Case Report and Review of the Literature. Case Rep Infect Dis. 2019; 2019:9364951. doi: 10.1155/2019/9364951.

8. Centor RM, Geiger P, Waites KB. Fusobacterium necrophorum bacteremic tonsillitis: 2 Cases and a review of the literature. Anaerobe. 2010; 16(6):626-8. doi: 10.1016/j.anaerobe.2010.08.005.

9. Zucca $E_{1}$ Bertoni $F$. The spectrum of MALT lymphoma at different sites: biological and therapeutic relevance. Blood. 2016; 127(17):2082-92. doi: 10.1182/blood-2015-12-624304.

10. Klein TO, Soll BA, Issel BF, Fraser C. Bronchus-associated lymphoid tissue lymphoma and Mycobacterium tuberculosis infection: an unusual case and a review of the literature. Respir Care. 2007; 52(6):755-8. PMID: 17521466.

11. Lumish $M$, Falchi $L$, Imber BS, Scordo M, von Keudell G, Joffe E. How we treat mature B-cell neoplasms (indolent B-cell lymphomas). J Hematol Oncol. 2021; 14(1):5. doi: 10.1186/s13045-02001018-6. 
Alba Muñoz Santa

Alba Bellés Bellés

Eric López González

Iván Prats Sánchez

Saray Mormeneo Bayo

Albert Bernet Sánchez

Jesús Aramburu Arnuelos

Maria Font Font

Lucía Fraile García

Mercè Garcia González

\section{Report of sexually transmitted infections prevalence in asymptomatic pregnant women under 25 years old in Lleida, Spain}

Sección Microbiologia Hospital Universitari Arnau de Vilanova, Lleida, Spain

Article history

Received: 12 July 2021; Revision Requested: 21 August 2021; Revision Received: 18 September 2021; Accepted: 21 September 2021; Published: 10 December 2021

\section{Sir,}

Chlamydia trachomatis (CT), Neisseria gonorrhoeae (NG), Trichomonas vaginalis (TV), and Mycoplasma genitalium (MG) are responsible for sexually transmitted infections (STIs) and have an important impact on reproductive health worldwide [1]. STls affect mainly women causing cervicitis and cervical discharge, although in most cases are asymptomatic [2]. Most complications of STls are associated to non-treated asymptomatic pregnant women in which adverse pregnancy outcomes such as premature rupture of membranes, chorioamnionitis, prematurity or low birth weight (LBW) have been reported. Limited data on the role of MG during pregnancy has been published, though a recent meta-analysis revealed it may result in spontaneous abortion and preterm birth, independently of co-infection with other STI [3,4].

Since most STls are asymptomatic, syndrome-based algorithms should not be used, but routine STIs screening tests must be implemented to improve obstetrical outcomes. The current recommendation of the Center for Disease Control and Prevention is to test all pregnant women during the first trimester, with retesting during the third one of women less than 25, and those selected according to risk criteria [5]. However, only in 7 out of 25 states of the European Union, STIs screening is part of prenatal control programs [6]. In Catalonia, it is included on the first trimester prenatal control but only offered to asymptomatic pregnant women under 25 years old or parturients with high risk of infection [7]. The objective of this study is to contribute to the report of CT, NG, TV and MG prevalence from the STIs screening program offered at our sanitary area to pregnant women under 25 years old.

A total of 537 endocervical swabs and 62 vaginal swabs specimens collected from 599 asymptomatic pregnant women

Correspondence:

Alba Muñoz Santa

Sección de Microbiologia y Parasitologia, Hospital Universitari Arnau de Vilanova

Institut Català de la Salut, Avd Rovira Roure 80, 25198 Lleida, Spain

E-mail:amsanta.lleida.ics@gencat.cat under 25 years old were screened for STIs from January 2019 to October 2020 at the Microbiology Department of the Hospital Universitari Arnau de Vilanova of Lleida, Catalonia, Spain. DNA of the specimens was extracted using EZ1 or OIASymphony equipment (QIAGEN ${ }^{\circledR}$, Hilden, Germany) and real-time multiplex PCR screening for $\mathrm{CT}, \mathrm{NG}, \mathrm{TV}$ and $\mathrm{MG}$ was performed using the Allplex ${ }^{\mathrm{TM}}$ STI-7 kit (Seegene ${ }^{\circledR}$, Seoul, Korea). The reaction was run on the CFX96 real time thermocycler (Bio-Rad ${ }^{\circledR}$, Hercules, California). Total STI prevalence was calculated as the number of positive specimens for all specimens analyzed, while $\mathrm{CT}, \mathrm{NG}, \mathrm{TV}$ and $\mathrm{MG}$ prevalence were done over the total number of positive STI microorganisms, including co-infections.

Total STIs prevalence was of 10.7\% (64/599). The prevalence of $\mathrm{CT}, \mathrm{MG}, \mathrm{TV}$ and $\mathrm{NG}$ is shown together with their percentage of coinfection in Table 1. The 4 targets in study were presented majority in single infection. The percentage of co-infections represents $12.5 \%$ of the total positive samples (8/64). Medical records of MG positive pregnant women were retrospectively reviewed to evaluate their pregnancy outcome. Three pregnant women out of 17 ended up in preterm premature rupture of membranes with no other apparent cause.

The objective of the prenatal STI screening is to detect asymptomatic pregnant women during the first trimester of pregnancy. This is the second report from Catalonia on STIs prevalence in asymptomatic pregnant women under 25 years old. In general, STls prevalence data in pregnant women is still scarce in Spain: Piñeiro et al. reported that CT prevalence was of 6.4\% in Gipuzkoa (2011-2014) [8] and in Catalonia, López-Corbeto et al. showed CT, NG, and MG prevalence of $9.8,3.7$, and $2.5 \%$, respectively [6]. STIs prevalence of our study are similar to those found in general youth population under 25 years old studied in Catalonia [9], where CT, NG and MG prevalence was of $8.5 \%, 0.6 \%$ and $3.5 \%$, respectively. This study was conducted in sexual and reproductive health centres throughout Catalonia, so it shows higher STIs prevalence. Moreover, a second study done in asymptomatic young sexually active patients attending the emergency room of our 


\begin{tabular}{|c|c|c|c|c|c|}
\hline Table 1 & \multicolumn{5}{|c|}{$\begin{array}{l}\text { Chlamydia trachomatis (CT), Mycoplasma genitalium } \\
\text { (MG), Trichomonas vaginalis (TV), and Neisseria } \\
\text { gonorrhoeae (NG) prevalence. Total number and } \\
\text { percentage of coinfection of each bacterial STI and } \\
\text { percentage of coinfection with other bacterial STI. }\end{array}$} \\
\hline \multirow{2}{*}{\multicolumn{2}{|c|}{ Total No. positive bacterial STI= 74}} & CT & MG & TV & NG \\
\hline & & $N(\%)$ & $N(\%)$ & $N(\%)$ & $N(\%)$ \\
\hline \multicolumn{2}{|l|}{ STI prevalence } & $43(6.2)$ & $17(2.5)$ & $10(1.4)$ & $4(0.6)$ \\
\hline \multicolumn{2}{|c|}{ N (\%) Total Coinfection } & $6(14)$ & $4(23.5)$ & $5(50)$ & $3(75)$ \\
\hline \multicolumn{6}{|c|}{ (\%) Coinfection with other bacterial STI } \\
\hline \multicolumn{2}{|l|}{ CT } & - & 17.6 & 25 & 66.7 \\
\hline \multicolumn{2}{|l|}{$M G$} & 5.2 & - & 8.3 & - \\
\hline \multicolumn{2}{|l|}{ TV } & 5.2 & 5.9 & - & 33.3 \\
\hline \multicolumn{2}{|l|}{ NG } & 3.5 & - & 16.7 & - \\
\hline
\end{tabular}

hospital for reasons unrelated to an STI showed a CT prevalence of $7.4 \%$ [10].

Regarding co-infections, our data suggest a moderate level of samples (12.5\%) with more than one STI detected. CT was more frequent in single infection (86\%) while NG was mainly in co-infection (75\%). This data is of interest as it demonstrates that co-infecting microorganisms should be tested so that they can have a significant impact on pregnancy and neonatal complications [6].

In Catalonia, according to the screening program only positive cases of CT, TV and NG are notified. Due to the moderate prevalence of $\mathrm{MG}$, more prospective studies evaluating whether screening programs improve reproductive outcomes in women are necessary to guide public health policies for this emerging pathogen $[3,4]$.

In conclusion, this study supports the need to screen STIS in asymptomatic pregnant women as part of prenatal care in Spain. Furthermore, we consider that there is a need of more extensive STIs prevalence studies, especially in parturients aged above 25 years old to support that the screening protocol could be broadened.

\section{ACKNOWLEDGMENTS}

The authors thank the laboratory technicians for their work on the preparation of the STI PCRs.

\section{FUNDING}

None to declare

\section{CONFLICT OF INTEREST}

The authors declare no conflicts of interest.

\section{REFERENCES}

1. López-Corbeto E, González V, Lugo R, Rivaya B, Casabona J, Matas L; CT/NG Study Group; Investigators of the CT/NG Study Group:. Pooling of urine samples for molecular detection of Chlamydia trachomatis, Neisseria gonorrhoeae and Mycoplasma genitalium as a screening strategy among young adults in Catalonia. Enferm Infecc Microbiol Clin. 2020 Feb;38(2):65-71. English, Spanish. doi: 10.1016/j.eimc.2019.05.003

2. Ortiz-de la Tabla V, Gutiérrez F. Cervicitis: Etiology, diagnosis and treatment. Enferm Infecc Microbiol Clin. 2019;37(10):661-667. doi: 10.1016/j.eimc.2018.12.004.

3. Lis R, Rowhani-Rahbar A, Manhart LE. Mycoplasma genitalium infection and female reproductive tract disease: a meta-analysis. Clin Infect Dis. 2015;61(3):418-26. doi: 10.1093/cid/civ312.

4. Donders GGG, Ruban K, Bellen G, Petricevic L. Mycoplasma/ Ureaplasma infection in pregnancy: to screen or not to screen. J Perinat Med. 2017;45(5):505-515. doi: 10.1515/jpm-2016-0111.

5. Peuchant O, Le Roy C, Desveaux C, Paris A, Asselineau J, Maldonado C, Chêne G, Horovitz J, Dallay D, de Barbeyrac B, Bébéar C. Screening for Chlamydia trachomatis, Neisseria gonorrhoeae, and Mycoplasma genitalium should it be integrated into routine pregnancy care in French young pregnant women? Diagn Microbiol Infect Dis. 2015;82(1):14-9. doi: 10.1016/j.diagmicrobio.2015.01.014

6. López-Corbeto E, González V, Casabona J; Grupo de estudio CT NG. First data of Chlamydia trachomatis and other STI prevalence and co-infections in pregnant women under 25 years in Catalonia, Spain. Med Clin (Barc). 2021;156(1):33-34. doi: 10.1016/j.medcli.2019.12.019.

7. Protocol de seguiment de l'embaràs a Catalunya. 3a ed. rev. Departament de Salut 1. Generalitat de Catalunya. Available from: https://scientiasalut.gencat.cat/handle/11351/1204

8. Piñeiro L, Lekuona A, Cilla G, Lasa I, Martinez-Gallardo LP, Korta J, Pérez-Trallero E. Prevalence of Chlamydia trachomatis infection in parturient women in Gipuzkoa, Northern Spain. Springerplus. 
2016;5:566. doi: 10.1186/s40064-016-2268-4.

9. López-Corbeto E, González V, Bascunyana E, Humet V, Casabona J; Grupo de estudio CT/NG-ASSIR y CT/NG-Prisiones. Tendencia y determinantes de la infección genital por Chlamydia trachomatis en menores de 25 años. Cataluña 2007-2014. Enferm Infecc Microbiol Clin. 2016;34(8):499-504. doi: 10.1016/j.eimc.2015.11.002.

10. Yuguero 0, Fernández-Armenteros JM, Vilela Á, Aramburu J, Laín R, Godoy P. Preliminary Results of a Screening Programme for Chlamydia in an Asymptomatic Young Population in Spain. Front Public Health. 2021;9:615110. doi: 10.3389/fpubh.2021.615110. 
Marta Pérez-Abeledo'

Belén Ramos'

Francisco Javier Candel

Juan Carlos Sanz ${ }^{1,2}$

\section{Rendimiento del ensayo de amplificación mediada por transcriptasa (TMA) Procleix SARS-CoV-2 para el diagnóstico de COVID-19 en "pools" de muestras nasofaríngeas. Pequeño estudio piloto}

\author{
${ }^{1}$ Laboratorio Regional de Salud Pública de la Comunidad de Madrid, Dirección General de Salud Pública, Consejería de \\ Sanidad Comunidad de Madrid, Madrid, España. \\ ${ }^{2}$ Consorcio de Investigación Biomédica de Epidemiología y Salud Pública (CIBERESP), España.
}

Article history

Received: 13 July 2021; Revision Requested: 27 July 2021; Revision Received: 27 July 2021; Accepted: 22 August 2021; Published: 26 December 2021

\section{Estimador Editor:}

Los procedimientos de RT-PCR para SARS-CoV-2 se basan en el uso de dianas que aportan información que varía en el grado de certeza según el número y tipo de genes investigados [1]. El gen $\mathrm{N}$ es muy sensible por lo que se ha postulado como "screening" de casos sospechosos [2]. Recientemente se han aplicado para el diagnóstico de COVID-19 técnicas de amplificación molecular isotérmica [3] como la amplificación mediada por transcriptasa (TMA). Este ensayo emplea las enzimas transcriptasa reversa y ARN polimerasa [4]. La técnica Procleix SARS-CoV-2 es una prueba de TMA, realizada mediante el equipo automatizado Panther, que puede ser utilizada como un método rápido de diagnóstico de COVID-19 [5]. Entre sus ventajas destacan la mínima manipulación y su elevada automatización. En condiciones de baja prevalencia de infección puede resultar coste-efectiva la estrategia de cribado el procesamiento por PCR agrupado de muestras clínicas ("pooling") [6]. Esta aproximación, aunque también se ha probado con TMA, con buenos resultados, ha sido poco ensayada [7]. El propósito de este estudio fue valorar el ensayo de TMA Procleix SARS-CoV-2 (Grifols Diagnostic Solutions Inc. Emeryville, California, EE. UU) en mezclas de muestras nasofaringeas para determinar su sensibilidad en el diagnóstico de COVID-19.

Se estudiaron 35 muestras previamente identificadas como positivas por TMA (gen N) mediante el ensayo Procleix SARS-CoV-2. Estas 35 muestras fueron mezcladas a partes iguales con muestras negativas, también estudiadas anteriormente por TMA, en 35 "pools" de cuatro (140 muestras, las 35 TMA positivas y 105 TMA negativas), 35 "pools" de ocho (280 muestras, las 35 TMA positivas y 245 TMA negativas) y 35

Dr. Juan Carlos Sanz Moreno

Unidad de Microbiologia Clinica. Laboratorio Regional de Salud Pública de la Comunidad de Madrid. Dirección General de Salud Pública de la Comunidad de Madrid.

Edificio Usos Múltiples Hospital Enfermera Isabel Zendal, Planta 1.

Avenida de Manuel Fraga Iribarne 2, Madrid 28055.

Tef: 917798865

E-mail:juan.sanz@salud.madrid.org "pools" de dieciséis (560 muestras, las 35 TMA positivas y 525 TMA negativas).

Las 35 muestras originales (sin diluir en mezclas) se procesaron también por RT-PCR usando la técnica Applied Biosystems TaqPath ${ }^{\text {TM }}$ COVID-19 RT-PCR Kit de Thermo Fisher Scientific (Life Technologies Corporation, Pleasanton, California, EE. UU), que incluye como dianas los genes ORF1ab, S y N. En este estudio, se valoraron únicamente los resultados de detección del gen N (detectado tanto por TMA como por RT-PCR).

Al analizar las muestras sin diluir por RT-PCR, en 30 de las 35 muestras que habian aportado originalmente resultados TMA positivos se obtuvo un resultado positivo (sensibilidad de la RT-PCR referida a la TMA del 85,71\%). Estas 30 muestras positivas por RT-PCR presentaban para el gen N un Ct que osciló entre 14,2 y 31,9. La distribución de resultados de las 35 muestras TMA positivas en relación con los resultados de RT-PCR se muestra en la tabla 1.

Al re-procesar por TMA las 35 muestras originalmente positivas mezcladas cada una de ellas con tres muestras previamente confirmadas como negativas (pool de cuatro [dilución 1/4]) o mezcladas con siete muestras previamente confirmadas como negativas (pool de ocho [dilución 1/8]) en todos los casos se obtuvieron resultados positivos (sensibilidad 100\%) (tabla 1). Cuando se re-procesaron por TMA cada una de las 35 muestras originalmente positivas mezcladas con quince muestras previamente confirmadas como negativas (pool de dieciséis [dilución 1/16] en 32 casos se observaron resultados positivos (sensibilidad 91,43\%) (tabla 1). Las 3 muestras negativas por TMA en la dilución 1/16 presentaban sin diluir un $\mathrm{Ct}$ para el gen $\mathrm{N}$ mayor a 37 (es decir también fueron negativas por RT-PCR para esta diana).

Los test clásicos de RT-PCR duplican el número de copias del gen diana en cada uno de los 40 ciclos habituales de su proceso, mientras que la amplificación por TMA genera cientos a miles de copias de la secuencia que subsecuentemente actúan como moldes de transcripción [8]. La sensibilidad anali- 


\begin{tabular}{l|lcc}
\hline Tabla 1 & \multicolumn{4}{|l}{$\begin{array}{l}\text { Distribución de resultados de las } 35 \text { muestras originalmente } \\
\text { TMA positivas en relación con los resultados de RT-PCR y } \\
\text { con los obtenidos por TMA en mezclas de 4, 8 y }\end{array}$} \\
\hline Grupos según el resultado de las muestras TMA positivas sin diluir & $n$ & Sensibilidad (\%) \\
\hline Positivas por TMA diluidas 1/4 con otras 3 muestras TMA negativas & $35 / 35$ & 100 \\
Positivas por TMA diluidas 1/8 con otras 7 muestras TMA negativas & $35 / 35$ & 100 \\
Positivas por TMA diluidas 1/16 con otras 15 muestras TMA negativas & $32^{\mathrm{a}} / 35$ & 91,43 \\
\hline
\end{tabular}

a Las 3 muestras negativas por TMA en la dilución 1/16 presentaban sin diluir un $\mathrm{Ct}>37$ para el gen $\mathrm{N}$.

tica en muestras clínicas del equipo Panther para el genoma de SARS-CoV-2 (de 5,5 × 10e3 copias por mililitro) es superior a la alcanzada por métodos de RT-PCR [8].

Es esperable que el uso masivo de las vacunas frente a SARS-CoV-2 reduzca en un futuro la incidencia de la infección. En este contexto, será conveniente establecer estrategias diagnósticas adaptadas a escenarios de carga de enfermedad variable [9]. En este estudio las muestras TMA positivas agrupadas con otras tres muestras TMA negativas o con otras siete muestras TMA negativas conservaron su positividad pese al correspondiente factor de dilución. Las tres muestras originalmente positivas por TMA, pero subsiguientemente negativas en dilución 1/16 habian sido negativas para el gen N por RT$P C R$, lo que sugiere que podrian corresponderse con muy bajas cargas víricas. Previamente se ha observado que señales de $\mathrm{Ct}$ en RT-PCR superiores a 35 pueden condicionar la aparición de resultados falsos negativos en mezclas de muestras estudiadas por TMA [10].

De acuerdo con los resultados de este estudio, y a pesar del reducido número de exudados nasofaringeos positivos incluidos, el agrupamiento de muestras en mezclas de cuatro u ocho "pools" puede ser una alternativa para el cribado por TMA de casos de COVID-19 en momentos en los que la incidencia sea baja.

\section{FINANCIACIÓN}

Los autores declaran que no han recibido financiación para la realización de este estudio.

\section{CONFLICTO DE INTERESES}

Los autores declaran no tener conflictos de intereses que puedan influir en lo expresado en este texto.

\section{BIBLIOGRAFÍA}

1. Li D, Zhang J, Li J. Primer design for quantitative real-time PCR for the emerging Coronavirus SARS-CoV-2. Theranostics. 2020;10(16):7150-7162. doi: 10.7150/thno.47649.

2. Chu DKW, Pan Y, Cheng SMS, Hui KPY, Krishnan P, Liu Y, et al. Molecular Diagnosis of a Novel Coronavirus (2019-nCoV) Causing an Outbreak of Pneumonia. Clin Chem. 2020;66(4):549-555. doi: 10.1093/clinchem/hvaa029.
3. Yu CY, Chan KG, Yean CY, Ang GY. Nucleic Acid-Based Diagnostic Tests for the Detection SARS-CoV-2: An Update. Diagnostics (Basel). 2021;11(1):53. doi: 10.3390/diagnostics11010053.

4. Rabaan AA, Al-Ahmed SH, Sah R, Al-Tawfiq JA, Haque S, Harapan $H_{1}$ et al. Genomic Epidemiology and Recent Update on Nucleic Acid-Based Diagnostics for COVID-19. Curr Trop Med Rep. 2020:17. doi: 10.1007/s40475-020-00212-3.

5. Trémeaux $P$, Lhomme $S$, Abravanel $F$, Raymond $S$, Mengelle $C$, Mansuy JM, et al. Evaluation of the Aptima ${ }^{\mathrm{TM}}$ transcription-mediated amplification assay $\left(\mathrm{Hologic}^{\circledR}\right)$ for detecting SARS-CoV-2 in clinical specimens. J Clin Virol. 2020;129:104541. doi: 10.1016/j. jcv.2020.104541.

6. Deka S, Kalita D. Effectiveness of Sample Pooling Strategies for SARS-CoV-2 Mass Screening by RT-PCR: A Scoping Review. J Lab Physicians. 2020;12(3):212-218. doi: 10.1055/s-0040-1721159.

7. Dierks S, Bader O, Schwanbeck J, Groß U, Weig MS, Mese K, et al. Diagnosing SARS-CoV-2 with Antigen Testing, Transcription-Mediated Amplification and Real-Time PCR. J Clin Med. 2021;10(11):2404. doi: 10.3390/jcm10112404.

8. Gorzalski AJ, Tian H, Laverdure C, Morzunov S, Verma SC, VanHooser $\mathrm{S}$, et al. High-Throughput Transcription-mediated amplification on the Hologic Panther is a highly sensitive method of detection for SARS-CoV-2. J Clin Virol. 2020;129:104501. doi: 10.1016/j. jcv.2020.104501.

9. Abdalhamid B, Bilder CR, McCutchen EL, Hinrichs SH, Koepsell SA, Iwen PC. Assessment of Specimen Pooling to Conserve SARS CoV2 Testing Resources. Am J Clin Pathol. 2020;153(6):715-718. doi: 10.1093/ajcp/aqaa064.

10. Newsom K, Zhang Y, Chamala S, Martinez K, Clare-Salzler M, Starostik P. The Hologic Aptima SARS-CoV-2 assay enables high ratio pooling saving reagents and improving turnaround time. J Clin Lab Anal. 2021:e23888. doi: 10.1002/jcla.23888. 